UNIVERSIDADE DE SÃO PAULO

INSTITUTO DE GEOCIÊNCIAS

\title{
MODERN POLLEN SIGNATURES OF THE AMAZON RIVER AND MAJOR TRIBUTARIES
}

\section{THOMAS KENJI AKABANE}

\begin{abstract}
Dissertação apresentada ao Programa Geociências (Geoquímica e Geotectônica) para obtenção do título de Mestre em Ciências.
\end{abstract}

Área de concentração: Geotectônica

Orientador: Prof. Dr. Paulo Eduardo de Oliveira 
Autorizo a reprodução e divulgação total ou parcial deste trabalho, por qualquer meio convencional ou eletrônico, para fins de estudo e pesquisa, desde que citada a fonte.

Serviço de Biblioteca e Documentação do IGc/USP

Ficha catalográfica gerada automaticamente com dados fornecidos pelo(a) autor(a) via programa desenvolvido pela Seção Técnica de Informática do ICMC/USP

Bibliotecários responsáveis pela estrutura de catalogação da publicação: Sonia Regina Yole Guerra - CRB-8/4208 | Anderson de Santana - CRB-8/6658

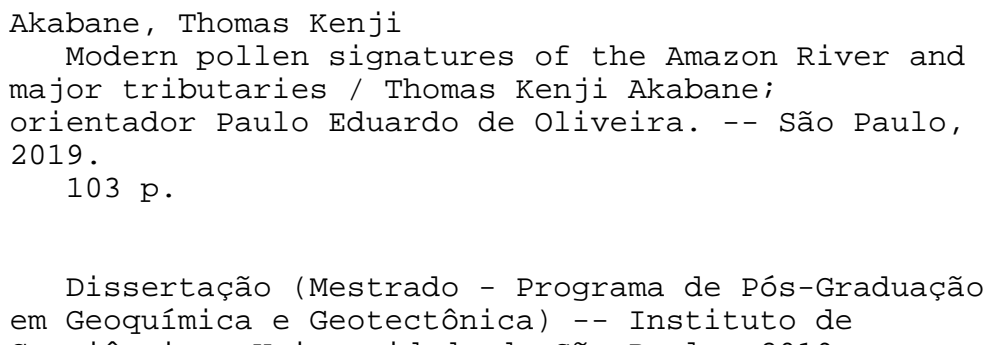




\title{
UNIVERSIDADE DE SÃO PAULO \\ INSTITUTO DE GEOCIÊNCIAS
}

\section{MODERN POLLEN SIGNATURES OF THE AMAZON RIVER AND MAJOR TRIBUTARIES}

\section{THOMAS KENJI AKABANE}

Orientador: Prof. Dr. Paulo Eduardo de Oliveira

Dissertação de Mestrado

№ 822

\author{
COMISSÃO JULGADORA \\ Dr. Paulo Eduardo de Oliveira \\ Dra. Marie-Pierre Winnie Ledru \\ Dr. Gregório Cardoso Tápias Ceccantini
}




\section{Agradecimentos}

Este trabalho não teria sido possível sem o agradável ambiente do Instituto de Geociências da USP e toda a convivência que este lugar proporcionou durante estes anos de mestrado. Por isso agradeço a todos e a todas que trabalham pelo crescimento, funcionamento e preservação da universidade e do instituto. Ao CNPq pela bolsa de mestrado (130581/2017-8), fundamental para a realização deste trabalho.

Agradeço ao Prof. Paulo de Oliveira pela orientação,

Pelas discussões e sugestões, André Sawakuchi, Maria Judite, Andrea Kern, Dailson Bertassoli, Cristiano Chiessi, André Stern (PM), Rudney Almeida, Vanda Medeiros, Jorge Pinaya, Maicon Alicrin, Jenny Watling,

Por tornar possível as análises eu agradeço à Jordana e demais técnicas (os) que trabalham nos laboratórios de Micropaleontologia Setembrino Petri, Sedimentologia, e Palinologia e Paleobotânica, e ao Prof. Daniel Atêncio.

À Katherine e ao Alexandre por todo auxílio ao longo deste processo,

Ao Henrique e Tadeu por ajudarem na impressão,

Aos demais funcionários e funcionárias do instituto por todo o suporte sempre,

Por "remover as barreiras da ciência", Alexandra Elbakyan

Por trazer leveza e café, por compartilhar as alegrias e os problemas que a vida de pós-graduando traz, aos amigos e amigas da pós-graduação, do Bosque, da palinologia e da ilha da magia.

Este trabalho é um fruto que só pôde ser colhido graças ao apoio daqueles que sempre estiveram presentes ao meu lado, por isso agradeço aos meus pais, Mário e Beth e irmã Heloisa, por toda a assistência e compreensão em todos os momentos. 


\title{
Amazonas
}

\author{
Amazonas, \\ capital das sílabas da água, \\ pai patriarca, és \\ a eternidade secreta \\ das fecundações, \\ te caem os rios como aves, te cobrem \\ os pistilos cor de incêndio, \\ os grandes troncos mortos te povoam de perfume, \\ a lua não pode vigiar-te ou medir-te. \\ És carregado de esperma verde \\ como árvore nupcial, és prateado \\ pela primavera selvagem, \\ és avermelhado de madeiras, \\ azul entre a lua das pedras, \\ vestido de vapor ferruginoso, \\ lento como um caminho de planeta.
}

Pablo Neruda (Canto Geral) 


\section{ABSTRACT}

Akabane, T. K., 2019. Modern pollen signatures of the Amazon River and major tributaries [Master's Thesis], São Paulo, Instituto de Geociências, Universidade de São Paulo, 98p.

Part of the controversy of the ongoing debate about the paleoecology of the Amazon results from the scarcity of modern data to better elucidate the sources and processes controlling the fluvial pollen record. The Amazon River transports large amounts of pollen gathered from the several distinct environments present in the current drainage basin, but how each of these environments contribute to the pollen record remains poorly studied. In order to assess this problem, the palynological content of 36 riverbed sediment samples covering from the mouth of Içá River to the Amazon Estuary was analyzed with the support of $x$-ray fluorescence (XRF) analysis. The palynological analysis shows that vegetation of lowland floodplains is the main source of the pollen transported by the Amazonian rivers. Therefore, aspects of fluvial dynamics and geomorphology that control vegetation over the floodplains echo in the pollen record. The upper reaches of Amazon River and western whitewater tributaries are responsible for an abundant Cecropia contribution, reflecting an early-successional vegetation induced by high rates of lateral erosion by the rivers and a landscape dominated by scroll-bars. The middle and lower reaches exhibit a progressive increase in herbs mainly represented by Poaceae, Cyperaceae, Asteraceae, Alternanthera, Amaranthus, and Acalypha, related to an opening in the floodplain vegetation cover and a flatter topography occupied by lakes. Floodplain forests of whitewater rivers (várzeas) are characterized by Iriartea, Mauritia, Ilex, Pseudobombax, and Luehea, which, in consortium with high amounts of Cecropia or herbs, suggest early to late stages of succession typical of these environments. The igapó forests, on the margins of black- and clearwater rivers, are palynologically expressed by higher values of Symmeria, Sapium, Piranhea, Pouteria, Amanoa, Myrtaceae, and Alchornea, which indicate conditions of higher environmental stability and a mature forest. Contribution from the Andean Mountains and from the cerrado are clouded by the pollen production of the lowlands. Extensive anthropogenic disturbance may reflect in a local increase of Cecropia, though its influence on the overall Amazonian signature is not detected. DCA analysis shows a gradual transition of the pollen signature from the upper to the lower reaches of the Amazon River, suggesting that the hindmost pollen signature is mainly influenced by the production along the main stem. Published palynological data are contrasted and discussed in the light of the present findings.

Keywords: Palynology, Amazon Basin, modern analogue, riverbed sediments. 


\section{RESUMO}

Akabane, T. K., 2019. Assinaturas palinológicas modernas do Rio Solimões-Amazonas e seus principais afluentes [Dissertação de Mestrado], São Paulo, Instituto de Geociências, Universidade de São Paulo, 98p.

Atualmente há uma grande quantidade de reconstruções paleoambientais, muitas vezes antagônicas, para tentar explicar a evolução ecológica da Amazônia. Parte da controvérsia decorre da escassez de dados modernos que permitam a comparação com o registro palinológico. O Rio Amazonas transporta grandes quantidades de pólen provenientes dos diversos ambientes que compõe a bacia de drenagem, no entanto 0 modo como cada um desses ambientes contribui para a formação do registro palinológico ainda é pouco conhecido. O presente estudo é baseado em análises palinológicas e de fluorescência de raios- $X$ de 36 amostras de sedimentos coletados com draga ao longo de rios entre a foz do rio lçá e o estuário do Amazonas, incluindo os principais tributários. A assembleia palinológica encontrada mostra que a vegetação da várzea é a principal fonte do pólen transportado pelos rios. Portanto, os aspectos da geomorfologia e da dinâmica fluvial que impactam a vegetação sazonalmente inundada ecoam no registro palinológico. Os trechos superiores do Rio Solimões e tributários de águas brancas do oeste amazônico são responsáveis por uma expressiva contribuição de Cecropia, refletindo estágios iniciais de sucessão vegetal causados pelas altas taxas de erosão lateral, distúrbios causados pelos rios e a formação de barras. Os trechos médio e inferior exibem um aumento progressivo de pólen de ervas, representadas principalmente por Poaceae, Cyperaceae, Asteraceae, Alternanthera, Amaranthus e Acalypha, e relacionadas a uma abertura na cobertura vegetal da várzea e a uma topografia mais plana ocupada por lagos de várzea. As florestas de várzea são caracterizadas palinológicamente por Iriartea, Mauritia, Ilex, Pseudobombax e Luehea, e conjunto à grandes quantidades de Cecropia ou ervas, sugerem estágios iniciais e tardios de sucessão vegetal. As florestas de igapó margeiam rios de águas claras e pretas e são expressas por altos valores de Symmeria, Sapium, Piranhea, Pouteria, Amanoa, Myrtaceae e Alchornea, que indicam condições de maior estabilidade ambiental e uma floresta madura. A produção de pólen das terras baixas sobrepõe o sinal proveniente dos Andes e do cerrado. Distúrbios antropogênicos, como extensos desmatamentos, podem refletir em um aumento local de Cecropia que não se expressa na assinatura que chega à região do estuário. A análise de DCA mostra uma transição gradual da assinatura polínica ao longo dos rios Solimões e Amazonas, sugerindo que a assinatura palinológica é influenciada principalmente pela produção ao longo do canal principal. Por fim, dados palinológicos publicados são comparados e discutidos à luz do presente estudo.

Palavras-chave: Palinologia, Bacia Amazônica, análogo moderno, sedimentos fluviais. 


\section{SUMMARY}

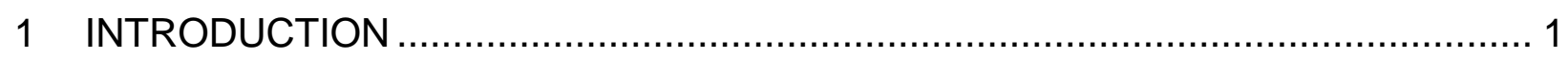

2 STUDY AREA

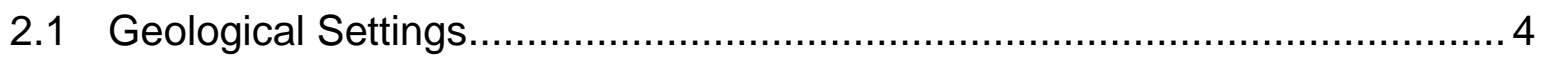

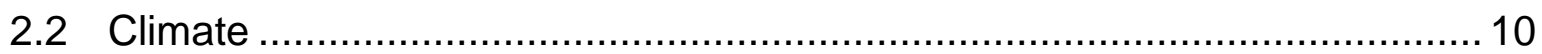

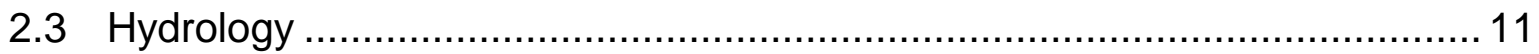

2.3.1 Whitewater Rivers ................................................................ 13

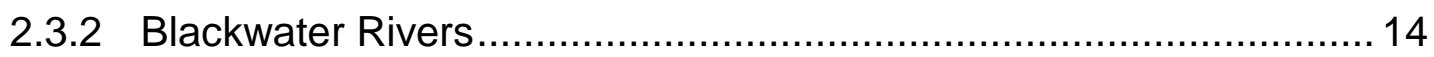

2.3.3 Clearwater Rivers ....................................................................... 14

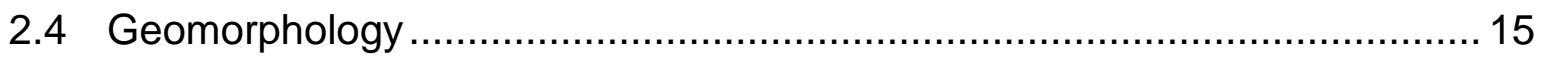

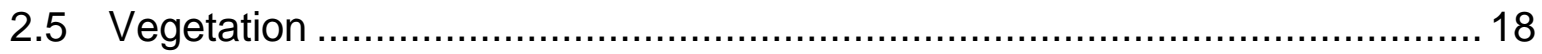

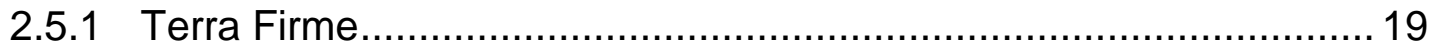

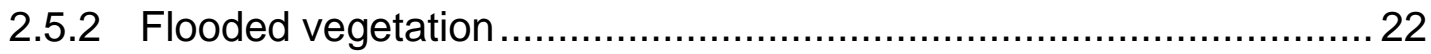

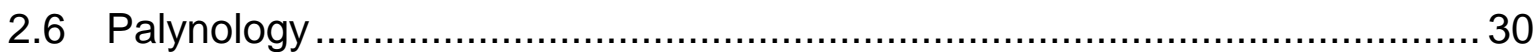

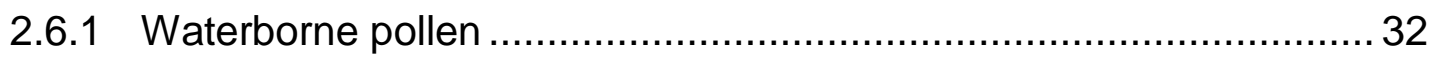

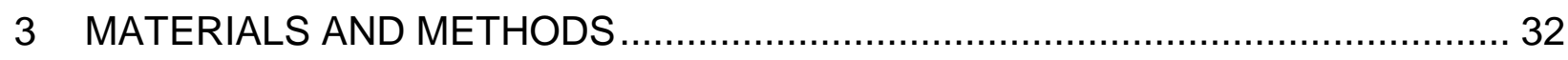

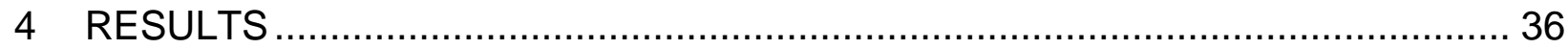

4.1 Sedimentary and Geochemical aspects ……........................................ 36

4.2 General Aspects of Surface Pollen Signatures........................................ 40

4.2.1 Pollen Concentration .............................................................. 40

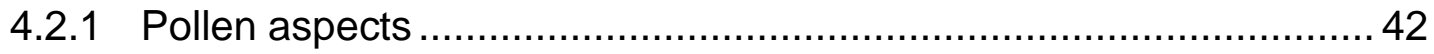

4.2.2 Pollen degradation ................................................................. 43

4.2.3 Reworked Fossil Palynomorphs ................................................. 45

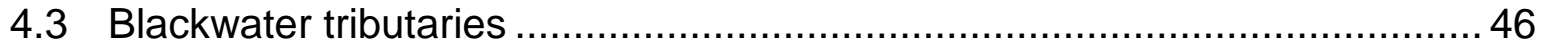

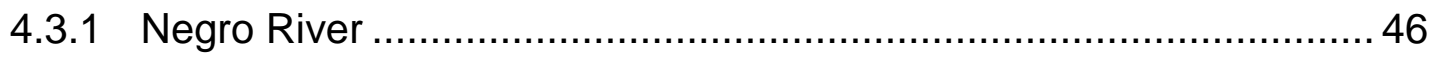

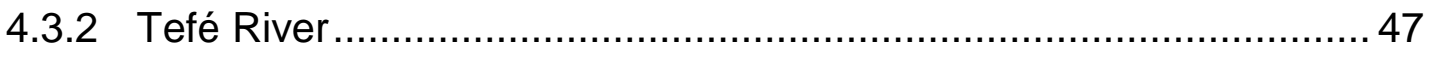

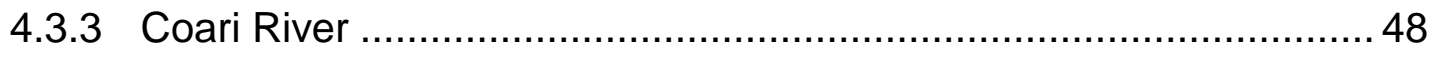

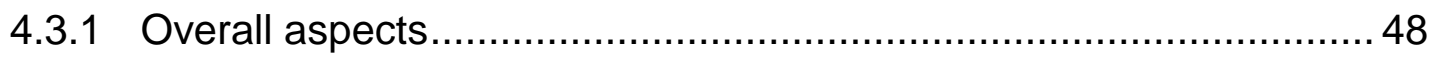

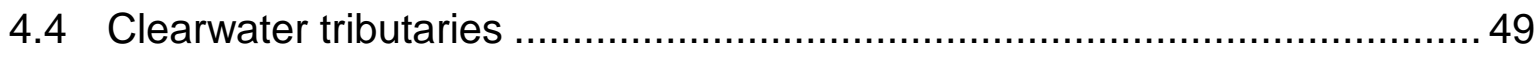

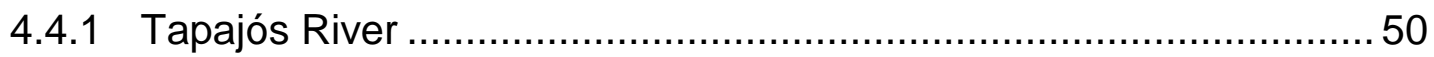

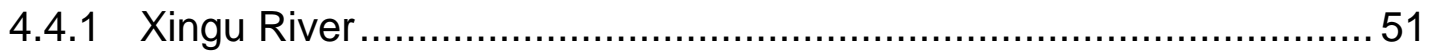

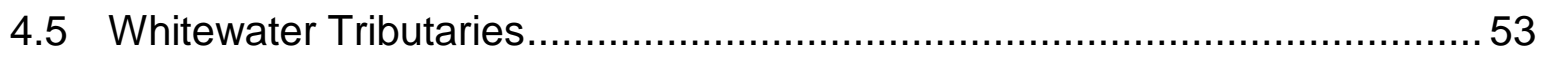

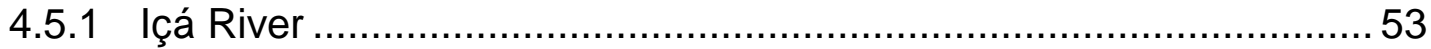




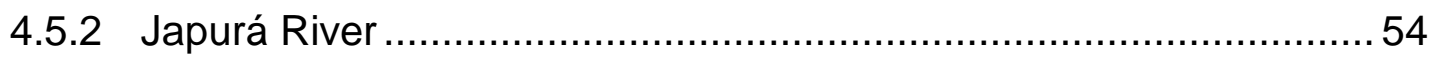

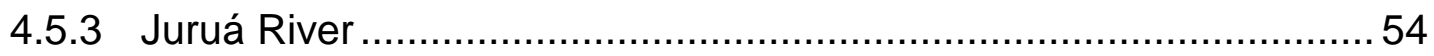

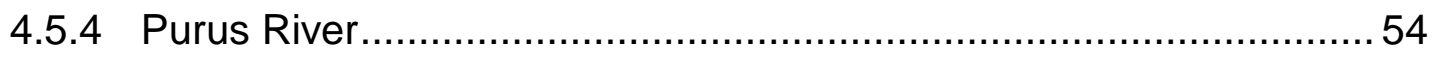

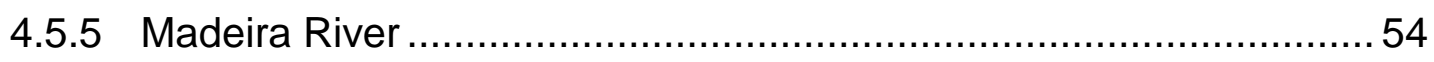

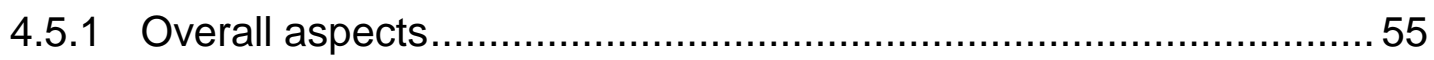

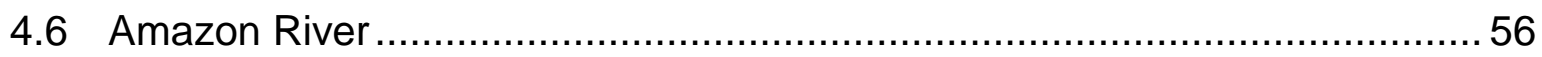

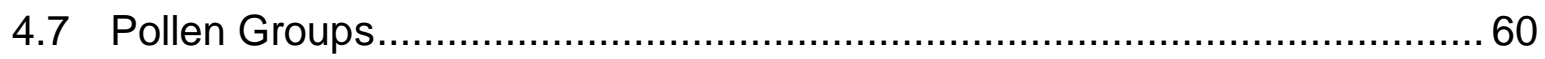

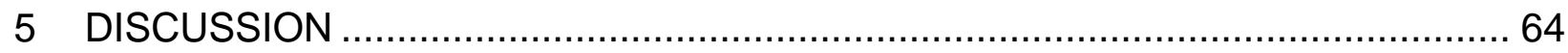

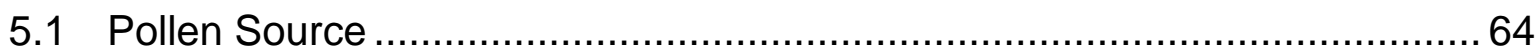

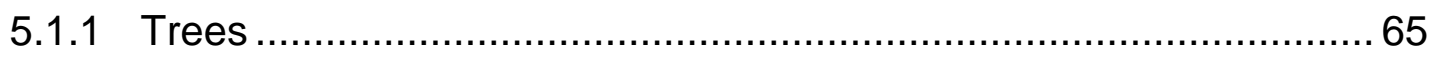

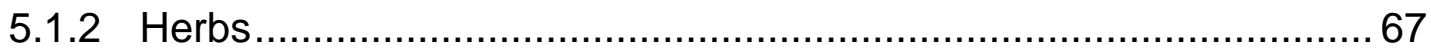

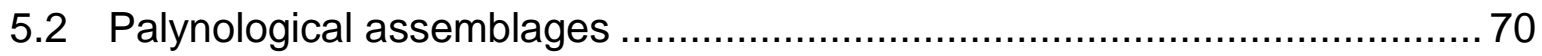

5.1 Detrended Correspondence Analysis (DCA) ...................................... 74

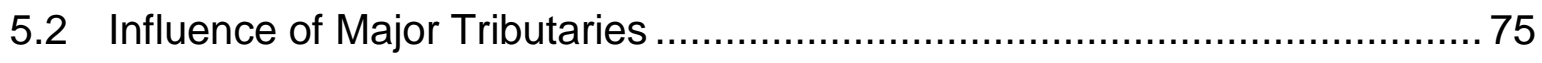

5.3 Comparison between the suspended and riverbed load............................ 77

5.4 Implications to Pollen Record ……....................................................... 79

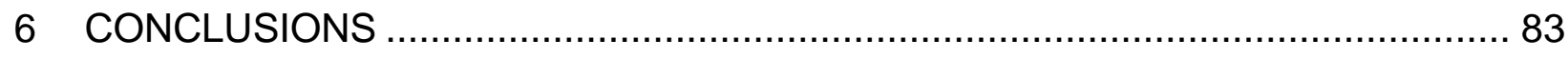

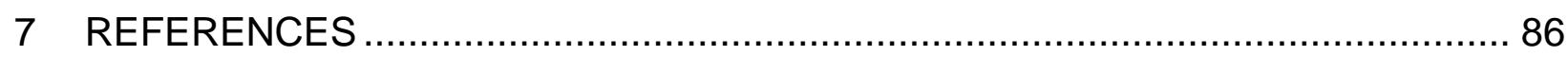

APPENDIX 1 - Ecology of parent taxa

APPENDIX 2 - Pollen plates 
Figure 1 - Hypsometric map of the Northern South American and drainage system. Amazon Basin delimited by a black contour. Sampling sites indicated by white dots...... 3 Figure 2 - a. Simplified geological map of the North South America. b. schematic longitudinal section of the Acre, Solimões, Amazon and Marajó basins shows structural arches and highs (Albert et al., 2018; after Caputo and Soares, 2016; Hoorn et al., 2017).

Figure 3 - Isopach map of the Solimões Formation (Maia et al., 1977, apud Latrubesse et al. 2007) 7

Figure 4 - Schematic section showing the main elements of the landscape in SW Brazilian Amazonia (lowlands) (Latrubesse et al., 2007).

Figure 5 - Correlation chart for the Neogene stratigraphy of Amazonia. The end of the Ucayali peneplanation event is estimated to lie between 9.5 and $9.0 \mathrm{Ma}$. 9 Figure 6 - Modern rainfall in South America. Long-term mean (1979-2000) for DecemberFebruary $(A)$ and June-August $(B)$. The mean positions of the Inter-tropical convergence zone (ITCZ) are shown in A and B (dashed line) (Maslin et al., 2011). 11

Figure 7 - Flooding frequency as number of months per year over the 10-year period of 2001- 2010 (Miguez-Macho and Fan, 2012)...

Figure 8 - The distribution of major whitewater, blackwater, and clearwater rivers in the Amazon basin (Junk et al., 2011) 13

Figure 9 - Schematic illustration of observed along-stream pattern of channel-floodplain geomorphology and valley width. JA—Jutaí arch, PA—Purús arch, MR—Madeira River confluence, and GA-Gurupá arch (Mertes et al., 1996). 16

Figure 10 - Flood amplitude in the Amazon River. Dots indicate bank height with respect to low water, and rectangles indicate the maximum flood height based on the difference between the lowest and highest river stage along the Amazon River. JA = Jutaí Arch; PA $=$ Purus Arch, MR = Madeira River (Mertes et al., 1996).

Figure 11 - Modern fluvial rias in the Solimões River floodplain (Bertani et al., 2015).. 18 Figure 12 - Successional forest is created on both sides of the meandering rivers. As the meandering proceeds, the sequential successional forest is cut and a mosaic forest structure is created (Salo et al., 1986). 24 
Figure 13 - Vegetation cover classes at low-water stage, extrated by L-band synthetic aperture radar imagery (adapted from Hess et al., 2003). Green squares represent the samples analysed in the present study.

Figure 14 - Riparian succession in the sequential successional flora in a western tributary (Manú River) (Salo et al., 1986). 28

Figure 15 - Schematic types of forest succession in várzea floodplains. Simplified from Wittman et al. (2011). 28

Figure 16 - Sampling sites over the studied area. 33

Figure 17 - Ternary diagrams based on sand/silt/clay ratios measured in Malvern. A: Diagram for the textural classification of sediments (Folk, 1974). 37

Figure 18 - Correlation of mean grain size measured on Malvern and Al/Si ratio, a grain size index, of all riverbed sediments. 38

Figure 19 - Geochemistry of riverbed sediments from rivers. The graphs show a clustering of whiteriver samples, which also include those from Coari and the Xingu-Amazonas confluence, and scattering of samples from Negro, Tefé and Xingu, indicating higher weathered sediments.

Figure 20 - Boxplot of $\mathrm{Al} / \mathrm{K}$ ratio shows that Coari and Xingu confluence samples have contribution of less mature sediments, typical of Solimões-Amazonas. 40 Figure $21-\mathrm{A}$ : Correlation of pollen concentrations and grain size proxy, Al/Si ratio. B: Boxplot of pollen concentration grouped according to water type; sediments coarser than sandy silt were removed.

Figure 22 - Pollen concentration (pollen grains $/ \mathrm{cm}^{3}$ ) (this study) and TOC (\%) presented by Sun et al. (2017).

Figure 23 - LOESS: Damaged grains through the Amazon River by distance from lquitos. Dark green squares: Solimões River; Light green squares: Amazon River; Grey band: $95 \%$ confidence band calculated by LOESS, with smoothing factor of 0,5 .

Figure 24 - Contribution of fungi spores according to water type (FS = Fungi Spores; PS $=$ total of Pollen and Pteridophyte Spores; DPS = Damaged Pollen and Spores)......... 44 Figure 25 - Correlation between grain size and damaged pollen and spores. 45 Figure 26 - Negro-Solimões confluence. Samples sites from Negro River indicated by yellow dots. River course during the dry season in black, flooding area in blue. Dense 
forest in green, open or transitional vegetation in light green, anthropogenically disturbed areas in white. 46

Figure 27 - Samples from Xingu River shown by light blue dots and from Tapajós River in dark blue. River course during the dry season in black, and floodplain in blue. Forested area in green, ecotone zone in light green and open physiognomy in yellow. Anthropogenic disturbed areas in white, such as occupated areas and the fishbone pattern.

Figure 28 - Whitewater tributaries and Solimões River in white labels. River course during the dry season in black, and during high water levels in blue. Forested area in green, ecotone zone in light green and open physiognomy in yellow. Anthropogenic disturbed areas in white. 53

Figure 29 - Sample sites along the Amazon River and tributaries. Places where the major tributaries intercept the mainstem are indicated as NG (Negro), MD (Madeira), TP (Tapajós), and XG (Xingu) 56

Figure 30 - Pollen diagrams of the Solimões-Amazonas River, grain size: Al/Si ratio, mineralogical maturity: $\mathrm{Al} / \mathrm{K}$ ratio, and distance from the River Mouth $(\mathrm{km})$. Fern spores $=$ Spores/ total(Pollen+Spores); Damaged grains = Damaged grains (pollen+spores)/ total(Pollen+Spores). 58

Figure 31 - Boxplot of the relation between várzea (VF) and igapó (IF) forests. The figure ilustrates that whitewater várzeas are dominated by VF and black and clearwater by IF elements. Lower Negro River, Xingu confluence and Tapajós sediments are enriched in taxa typical of várzea.

Figure 32 - Pollen percentage graphs. Ce - Cecropia, Po - Poaceae, Sy - Symmeria, My - Myrtaceae, Me - Melastomataceae, VF - Várzea forest, VH - Várzea Herbs, IF - Igapó forest, MO - Montane taxa, LM - Late to Mature forest, SA - Savanna taxa (x10 exagerrated), $n$ - number of analyzed samples. ${ }^{*}$ Percentages based on less than 200 pollen grains. 63

Figure 33 - Percentages of classes of vegetation cover (Hess et al., 2003) versus pollen percentages. The samples for comparison are those inserted in the areas analyzed by Hess et al. (2003), except the samples of the Lower Solimões, which are located immediately downstream of the area. 1. Contribution of várzea herbs $(\mathrm{VH})$ and Poaceae 
(Po) correlate with the floodplain area occupied by nonwoody vegetation. 2. Contribution of várzea trees is related to floodplain woody vegetation cover. 65 Figure 34 - Correlation of square-root counting values of Poaceae versus Várzea herbs, Lower Negro and Pará rivers samples are removed.. 70

Figure 35 - Ternary diagrams A. based on IF (igapó forest), VF (várzea forest), and VH (várzea herbs). B. based on IF+My (Myrtaceae), VH+Po (Poaceae), VF+MO (Montane taxa).

Figure 36 - Ternary diagram of late to mature successional forest (LM), Cecropia, and várzea herbs $(\mathrm{VH})$. 72

Figure 37 - Schematic floodplain geomorphologic features in three areas of the basin. Charactistic palynological signal and aspects of the floodplain listed aside.. 73

Figure 38 - Results of DCA ordination of modern pollen data, in percentage, from the Amazon Basin..

Figure 39 - Percentage values of types and groups along the Amazon River, distance measured from lquitos, Peru. Analyzed riverbed sediments (present study) are represented by squares.

Figure 40 - DCA of modern pollen data (this study) and Foz do Amazonas data from Haberle (1997) in three moments: Pleniglacial, Last Glacial Maximum (LGM), and Postglacial (PG).. 80

Figure 41 - Source of the main pollen signatures transported by the drainage system of the Amazon Basin. 85 
Table 1 - Sample code, river, position, depth of sampling, season, granulometric and palynological aspects. 36

Table 2 - Percentage representation of pollen in blackwater tributaries riverbed sediments.

Table 3 - Percentage representation of pollen in clearwater tributaries riverbed sediments.

Table 4 - Percentage representation of pollen in whitewater tributaries riverbed

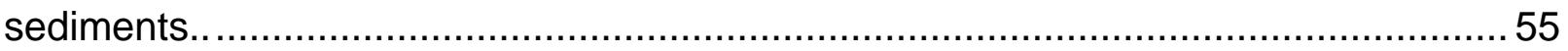

Table 5 - Percentage representation of pollen in Solimões riverbed sediments. .......... 59

Table 6 - Percentage representation of pollen in Amazonas riverbed sediments 59

Photo 1 - A. Outcrop of Alter-do-Chão Formation in Monte Alegre region, Pará. B. Crossbedded sandstones intercalated with thin conglomerate layers. Photo: Thomas Akabane.

Photo 2 - Confluence of the Tapajós and Amazon rivers. Photo: Thomas Akabane. ... 15 Photo 3 - Vegetated levee at the Amazonas-Tapajós confluence. Photo: Thomas Akabane. 16

Photo 4 - Tree draped in lianas at Altamira, Pará, region. Photo: Thomas Akabane....20 Photo 5 - Open vegetation edaphically restrained, locally called capoeiras, near the city of Monte Alegre, Pará. Photo: Thomas Akabane. 21

Photo 6 - Lavrado, in Pacaraima, Roraima. (Photo: André Stern) .22

Photo 7 - Stands of aninga (M. arborescens) and embaúba (Cecropia sp.) on the Amazon River margin, at Distrito Portuário de Santana do Tapará, Pará. Photo: Thomas Akabane. 23

Photo 8 - Grasses growing over exposed lands during low water levels, Iriri River, Pará. Photo: Thomas Akabane. 25

Photo 9 - Igapó forest understory at Xingu River floodplain. Trees buttressed by tabular roots are common in seasonal inundated forests. Photo: Thomas Akabane. 29

Photo 10 - Van Veen sampler. Photo: André Stern. 34

Photo 11 - Deforested areas for pasture in Altamira region. A. Aerial view. B. Attalea palms growing on a deforested area. C. Pastures for cattle ranching. Photos: Thomas Akabane. 


\section{INTRODUCTION}

The Amazon Basin is the world's largest drainage basin and home to the most species-rich terrestrial ecosystem, in an area that encompasses almost half of the planet's remaining rainforests. The geological, climatic and biological evolution of this complex system is subject of an ongoing debate and a holistic approach is necessary for a better comprehension of the intricate Hyleaen history.

Palynology has an essential role in assessing past floristic shifts and as the vegetation tightly relates to the climate, hydrology and geomorphology, it works as a great paleoenvironmental tool (Salgado-Labouriau, 2007; Traverse, 2007). This is due to the fact that the pollen wall is made of an extremely stable biopolymer complex called sporopollenin that can last for hundreds of million years preserved in sediments (Brooks and Shaw, 1978; Schulte et al., 2008). This structure usually has striking features that allows us to trace back its parent-plant at family, genera and sometimes species level. Several palynological studies have been carried out to reconstruct the evolution of the Amazon Basin based on sediment cores collected in terra firme lakes (Colinvaux et al., 1996; Bush et al., 2004; Soares et al., 2017), floodplain lakes (Horbe et al., 2011; Sá et al., 2016), riverbanks (Latrubesse et al., 2010; Feitosa et al., 2015), shallow cores in tributaries (Behling et al., 2001; Irion et al., 2006), deep borehole (Hoorn, 1993), and the sedimentary deposits of the Amazon Fan (Haberle, 1997; Hoorn, 1997; Haberle and Maslin, 1999; Hoorn et al., 2017). Although it is possible to recognize floristic changes over the geological time, most of the studies on fluvial system deposits had their palynological interpretations carried out without the support of broader studies on the representativeness of the modern vegetation. The current knowledge of the modern fluvial palynological signatures along the main Amazon River is limited to a few suspended sediment samples analyzed by Haberle (1997).

The pollen content transported by the Amazon River derive from the riverbank vegetation, floating meadows, terra firme, extra-Amazonian regions, and reworked sediments of the floodplain. Sediments, as well as pollen grains gathered since the drainage headwaters, can be transported, deposited and reworked over thousands of kilometers before finally reach the ocean (Muller, 1959; Johnsson and Meade, 1990; 
Hoorn, 1997). Differently from endorheic lakes enclaved amid terra firme forests, that act like a steady closed system, the fluvial systems are highly dynamic and influenced by a seasonal flooding regime, which restrict the edge vegetation to a lesser range of dominant várzea-adapted species (Kalliola et al., 1991; Wittmann et al., 2006). Frequent habitat disturbance by flooding, erosion of river margins and bars, and lateral channel shift, promotes an abundance of pioneer and early-successional vegetation along the Amazon River (Salo et al., 1986; Kalliola et al., 1991). The dynamics that affects the floristic aspects of floodplain reflect in the palynological record. According to Burn et al. (2010), the differentiation of riparian and terra firme pollen assemblages is driven mainly by the abundance of wind-pollinated taxa. The dominance of few anemophillous taxa, such as Cecropia, Poaceae, Alchornea and Moraceae contrasts with the rich diversity of entomophilous taxa that comprises the Amazon rainforest (Colinvaux et al., 1999).

The interpretation of the pollen records relies on a basic understanding of their sources, dispersal and depositional mechanisms (Bush and Rivera, 1998; Burn et al., 2010), which are still poorly known for the Amazon Basin fluvial system, although imperative for an accurate interpretation since the main sources of some pollen-types found in the record still remains obscure.

In this work, the modern palynological content of riverbed sediments collected along some of the main tributaries of the Brazilian Amazon Basin was analyzed to determine its sources in order to establish its relationship to different landscape variables. Multivariate analyses were applied to investigate gradients of variability and to distinguish the assemblage of the main tributaries; grouping pollen-types according to ecological aspects allows discriminating sources and making inferences about fluvial geomorphological features that influence the pollen record. Geochemical and grain size analyses were used to evaluate the source of the inorganic sediments as support for the palynological data. Sediment sources were distinguished on the basis of $\mathrm{Al} / \mathrm{K}$ ratio, as mineralogical maturity index (Guyot et al., 2007), together with $\mathrm{Fe} / \mathrm{Ca}$ and $\mathrm{Fe} / \mathrm{K}$ ratios (Vital and Stattegger, 2000; Häggi et al., 2016). The Al/Si ratio, a grain size proxy (Bouchez et al., 2011), was used to evaluate sorting effect and pollen concentration on the sediments. 


\section{STUDY AREA}

The catchment of the Amazon Basin covers a very extensive geographic area and a diversity of ecosystems. The lowland tropical forest spreads over most of the drainage system and is underpinned by the Amazon River, which can be considered an artery to where the system converges before flowing into the Atlantic. It also drains part of the cerrado of Central Brazil, the savannah of the Guianas and the Andes in its western-most headwaters. The Guianas and Central-Brazil platforms respectively separate the Amazon from the Orinoco Basin to the north and from the Paraná Basin to the south.

The study area comprises some of the main tributaries of the Amazon Basin between the lower reaches of the Içá River (3,115오 and 68,067ㅇ) and the Amazon Estuary (1,504ㅇ $\left.48,910^{\circ} \mathrm{W}\right)$ (Figure 1). The analyzed samples are from the rivers Solimões, Amazonas, Içá (Putumayo), Juruá, Coari, Japurá (Caquetá), Tefé, Purus, Negro, Madeira, Tapajós, Xingu, and Pará. The Pará River is a clearwater river that disembogues south of the Marajó Island and is mainly formed by the confluence of Tocantins and a branch of the Amazonas River, via long and narrow channels known as furos.

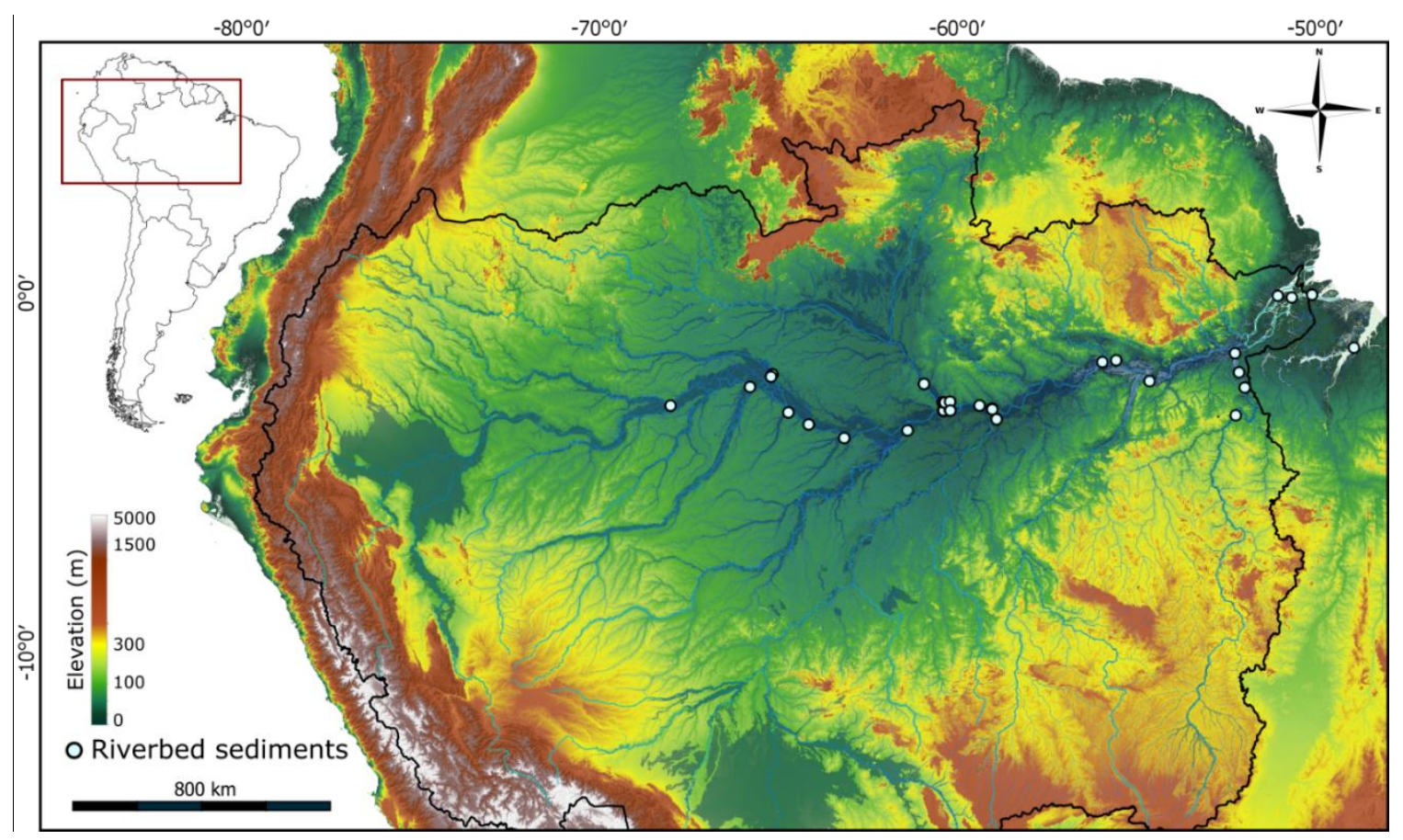

Figure 1 - Hypsometric map of the Northern South American and drainage system. Amazon Basin delimited by a black contour. Sampling sites indicated by white dots. 


\subsection{Geological Settings}

The modern Amazon Basin originated from an ancient zone of weakness of the Precambrian Amazon Craton. The Craton is stretched between two parts, in the north the Guiana Shield and in the south the Central-Brazilian Shield, and is limited to the west by the Andes Orogenic Belt, and to the east and southeast by the Neoproterozoic Araguaia belt. The craton is a result of an amalgamation of provinces, in a process that ended by the Neoproterozoic, composed by igneous and metamorphic rocks of Archean and mainly Proterozoic age (Santos et al., 2000) (Figure 2.a).

The approximate depression that fits the modern sedimentary basin already existed in the Gondwana continent, divided by three structural arches (highs) that separate the Paleozoic-Mesozoic Basins (Putzer, 1984). In the west, the Iquitos Arch crosses near the homonymous city and separates Acre and Andean Foreland basins from the Solimões Basin; the Purus Arch, west of Manaus, separates the Solimões and Amazonas basins; and the Gurupá Arch, separates the latter from the Marajó Basin (Caputo and Soares, 2016) (Figure 2.b). The Phanerozoic sedimentary fill can exceed $5000 \mathrm{~m}$ thick, resultant of a tectonic subsidence and deposition that started at the Paleozoic, while the uplift of regional arches controlled the distribution of the fill (Putzer, 1984).

Paleozoic units rarely outcrops, such as along riverbanks at the basin margins, flanks of the Amazon valley (e.g. Trombetas Formation), or the Monte Alegre Dome region (Putzer, 1984; Oliveira and Lima, 1990; Wanderley-Filho et al., 2009). This sequence, deposited from the Ordovician to the Permian, was formed under marine, coastal, fluviolacustrine, and glacial environments (Putzer, 1984). By the end of the Paleozoic, basin uplift and the subsequent intrusion of Late Triassic diabases promoted erosion of the sedimentary cover and interrupted deposition until the Late Cretaceous (Wanderley-Filho et al., 2009). 


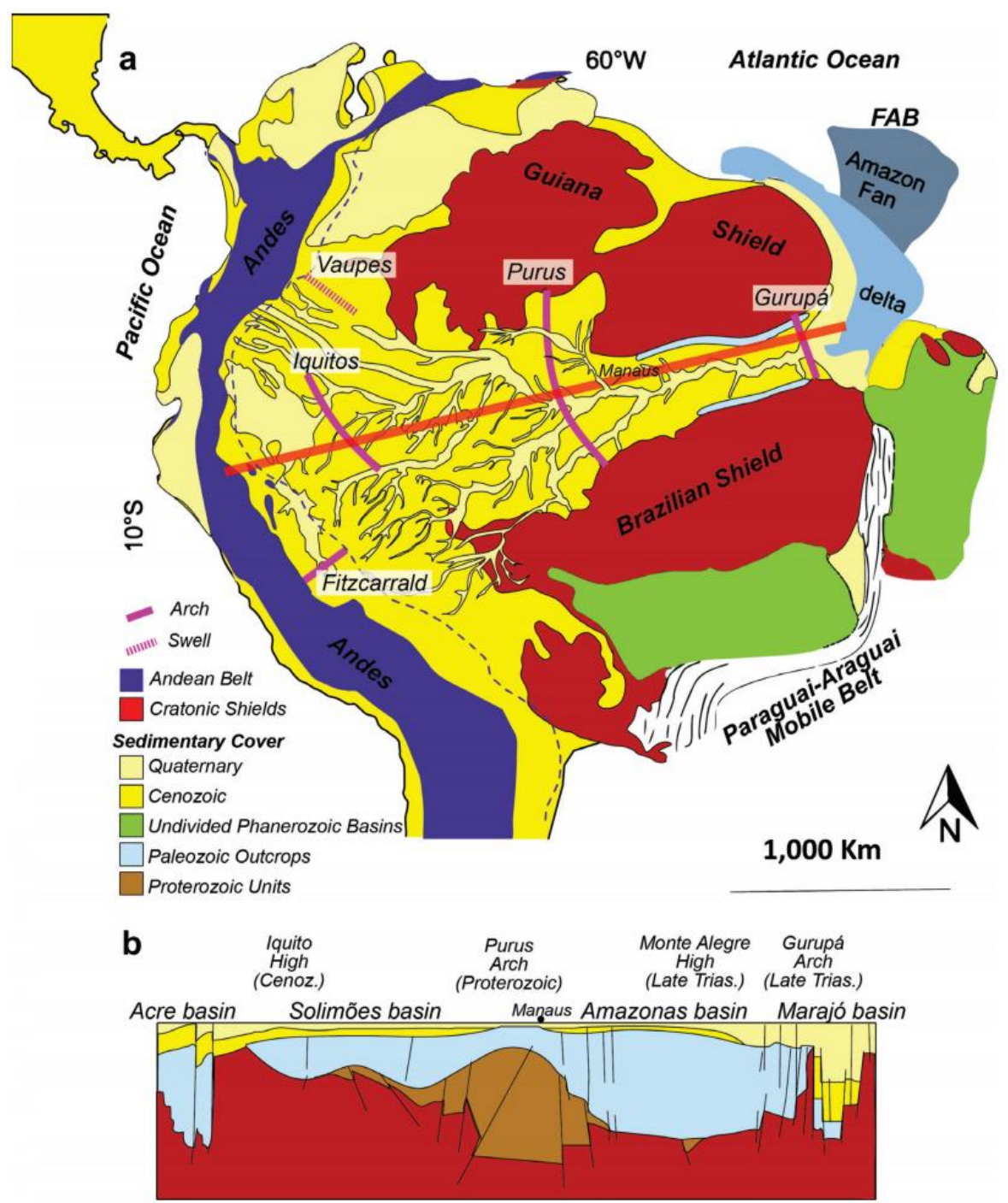

Figure 2 - a. Simplified geological map of the North South America. b. schematic longitudinal section of the Acre, Solimões, Amazon and Marajó basins shows structural arches and highs (Albert et al., 2018; after Caputo and Soares, 2016; Hoorn et al., 2017).

Global tectonic events during Cretaceous, such as the spreading of the Atlantic Ocean, resulted in a reorganization of the Amazon basin. After the long hiatus period, subsidence and deposition resumed at the Late Cretaceous in Solimões and Amazonas basins and sediments of the eastern Amazonas Basin began to reach the Atlantic sea (Putzer, 1984). The unit deposited over both basins during the Late Cretaceous until the Paleocene is the Alter-do-Chão Formation (Photo 1) that consists of deposits of fluvial, deltaic, and lacustrine sediments intercalated with conglomerates. 

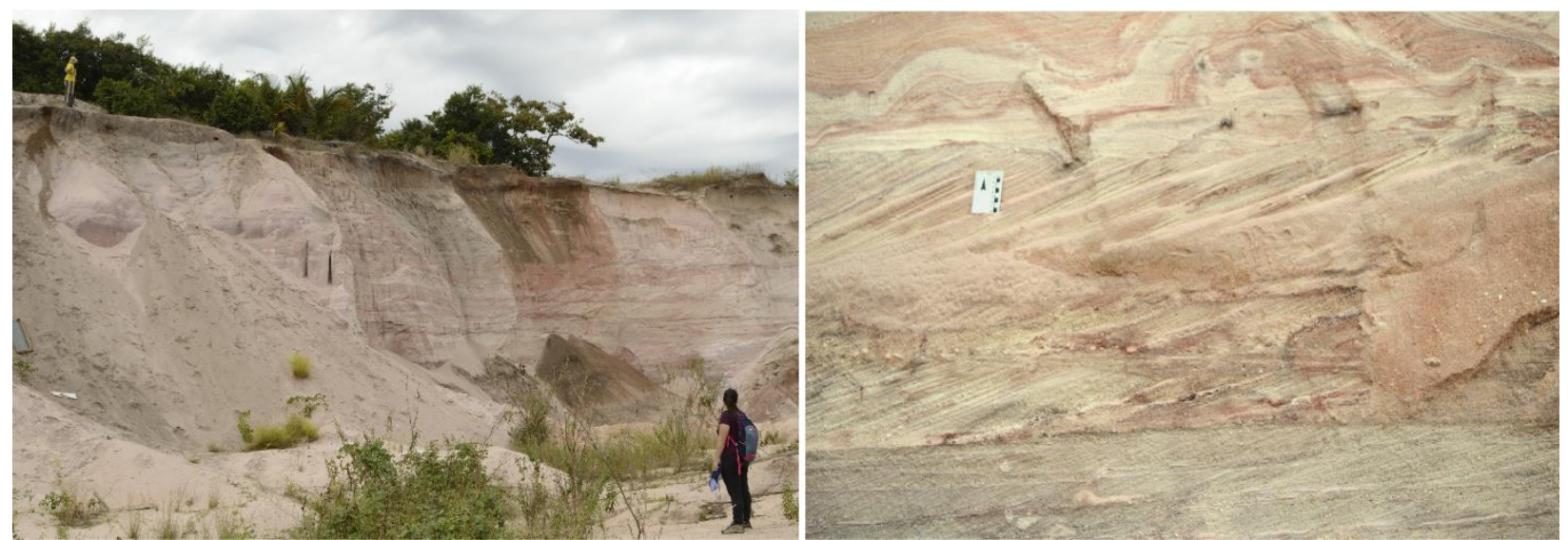

Photo 1 - A. Outcrop of Alter-do-Chão Formation in Monte Alegre region, Pará. B. Cross-bedded sandstones intercalated with thin conglomerate layers. Photo: Thomas Akabane.

The Andean Cordillera orogeny caused an overload and lithospheric flexuring, shifting the Cenozoic basin depocentre to the sub-Andean foreland basins (Roddaz et al., 2009; Wanderley-Filho et al., 2009). Extensive Paleogene deposition appears to be restricted to the foreland basins of the Western Amazon (Roddaz et al., 2009). The Miocene Solimões Formation cover almost all Western Brazilian Amazonia and can reach thickness over $1000 \mathrm{~m}$ along the border between Acre and Amazonas states (Figure 3) (Hoorn, 1993; Latrubesse et al., 2007). It extends from the western Brazilian border region, where it reaches its maximum thickness, and thinning to the Purus arch, which was the eastward depositional limit of the basin (Latrubesse et al., 2007, 2010). The Solimões Formation is mainly formed of sandstones, siltstones, and claystones, and unconformably overlay the Alter-do-Chão Formation in the upper Solimões region, outcropping along riverbanks and road cuts (Figure 4) (Latrubesse et al., 2007).

The Early and Middle Miocene Solimões Formation register two rapid events of marine incursions from north, intercalated with episodes of fluvial, deltaic, estuarine environments and presence of mega-wetlands environments (Hoorn, 1993; Jaramillo et al., 2017; Albert et al., 2018), although some authors criticize the marine incursion hypothesis (e.g. Campbell Jr. et al., 2006; Latrubesse et al., 2010). According to Latrubesse et al. (2010), the uppermost Solimões Formation of Late Miocene age, represents a system of avulsive rivers in aggradational conditions, with floodplain facies, lateral accretion deposits, and local crevasse-splays. The fossil fauna and palynological 
record indicate an environment dominated by grasslands and gallery forests under a tropical to subtropical climate (Latrubesse et al., 2007). According to Latrubesse et al. (2007, 2010), these sediments could only be deposited prior to the establishment of a transcontinental Amazon system, when the southwestern Amazonia acted as an effective sedimentary basin. By the Late Miocene-Pliocene, deposition of Solimões Formation ceased and instead became an erosional area, as consequence of a reorganization of the drainage basin to a modern-like system. However, some authors consider these deposits as belonging to the Içá Formation and support alternative explanations for the evolution of the Amazon Basin (e.g. Rossetti et al., 2005, 2015; Campbell et al., 2006). East of Purus Arch, occurs Miocene sedimentary deposits designate as Novo Remanso Formation, formed of cross-bedded sandstones intercalated with argilites and representative of a meandering fluvial system (Dino et al., 2012). Notwithstanding, some authors question the role of Purus arch in Neogene events, once, during this period, this structural high was already buried beneath hundreds of meters of Cretaceous and Cenozoic sediments (Campbell et al., 2006; Campbell, 2010).

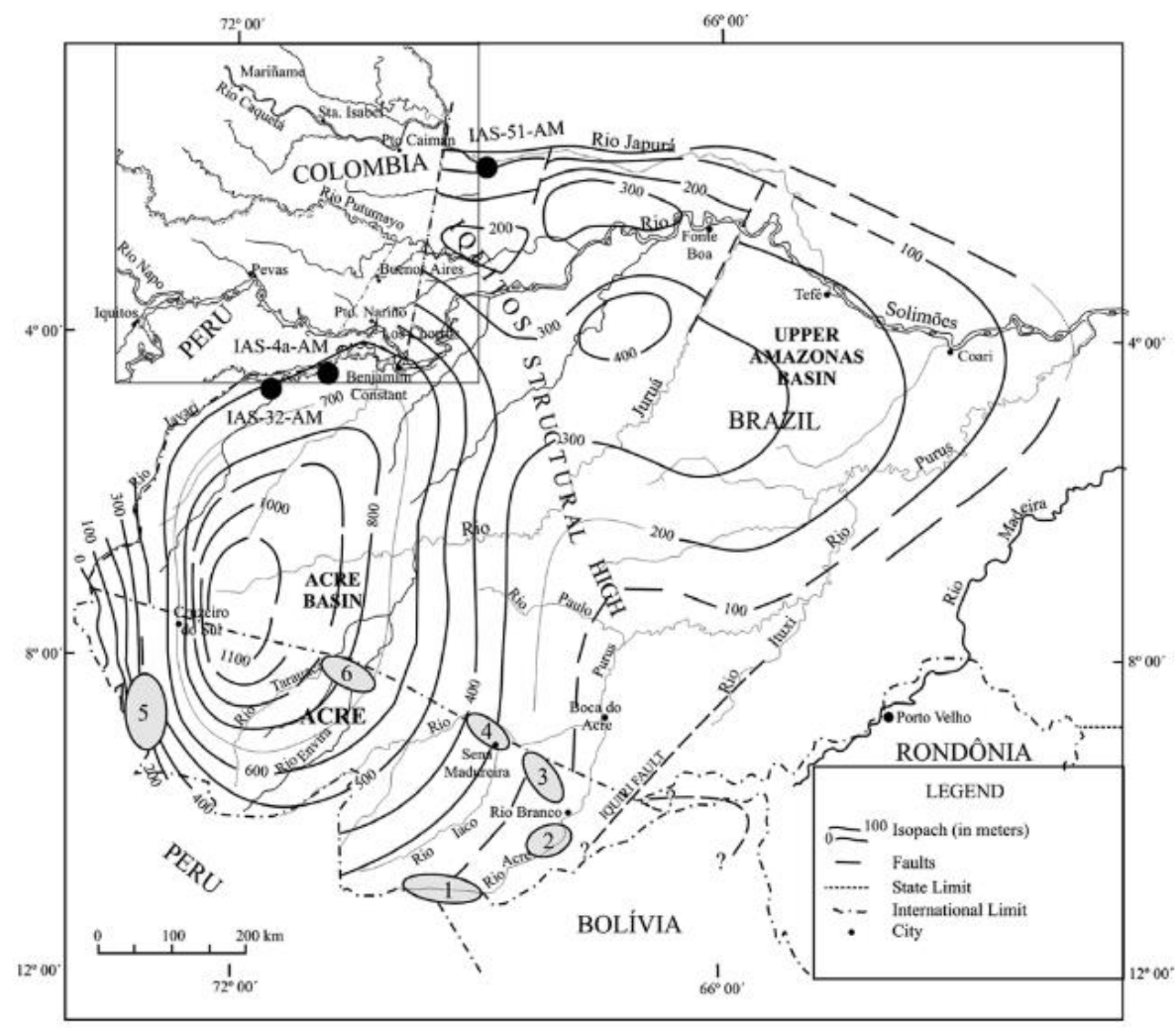

Figure 3 - Isopach map of the Solimões Formation (Maia et al., 1977, apud Latrubesse et al. 2007) 


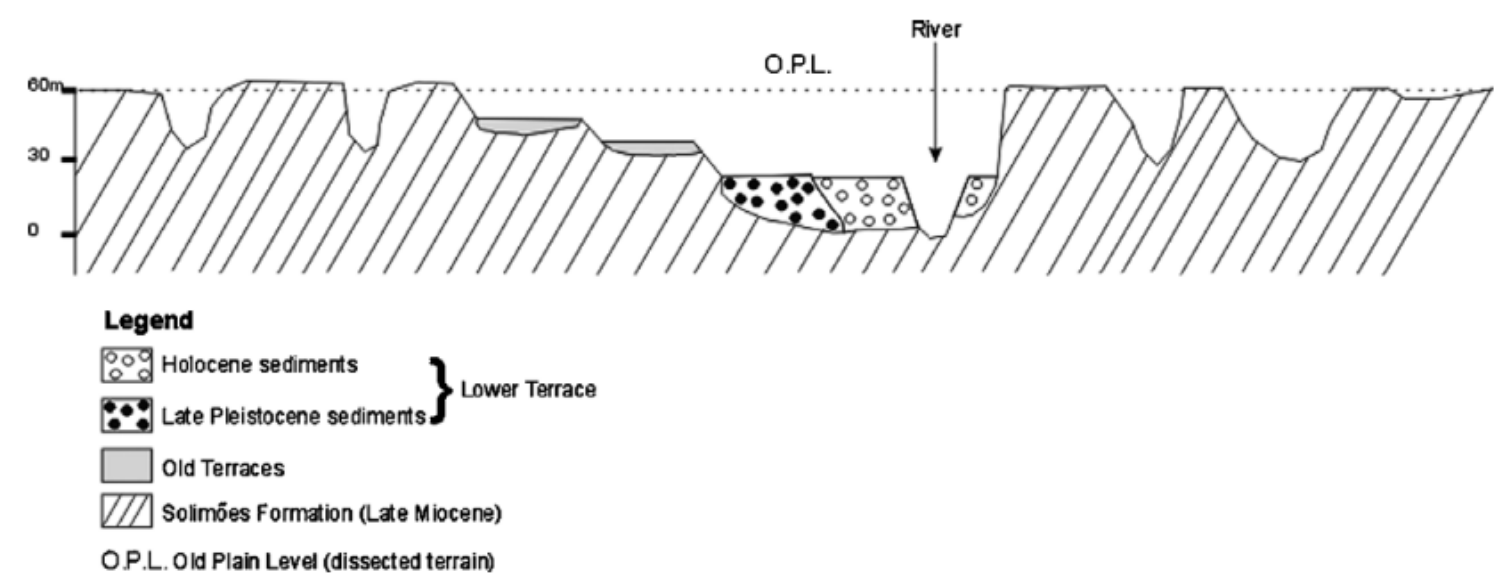

Figure 4 - Schematic section showing the main elements of the landscape in SW Brazilian Amazonia (lowlands) (Latrubesse et al., 2007).

The Içá Formation lies unconformably over the Solimões Formation and under Late Pleistocene-Holocene deposits, attributed to a wide range of ages, from the Miocene (e.g. Campbell et al., 2006) to the Mid-late Pleistocene (Rossetti et al., 2005, 2015). These deposits are dominated by sandstones generally interbedded with mudstones, also contains concentrations of iron oxides and hydroxides forming highly ferruginous beds (Rossetti et al., 2015). Campbell et al. (2006) describe the Madre de Dios Formation, which they correlate with Içá Formation, as containing basal conglomerates, thick horizons of sand and thinner layers of clay, with paleochannels often filled with clay-pebble conglomerates. They interpret these deposits as of fluvial, fluvio-deltaic, deltaic, and lacustrine origin, formed after the Pan-Amazonian Ucayali Uncoformity (Figure 5). According to Campbell et al. (2006), these sediments express paleodeltas and the evolution of a mega-lake complex, Lago Amazonas, prior to the establishment of the modern Amazon drainage system at $\sim 2.5 \mathrm{Ma}$. 


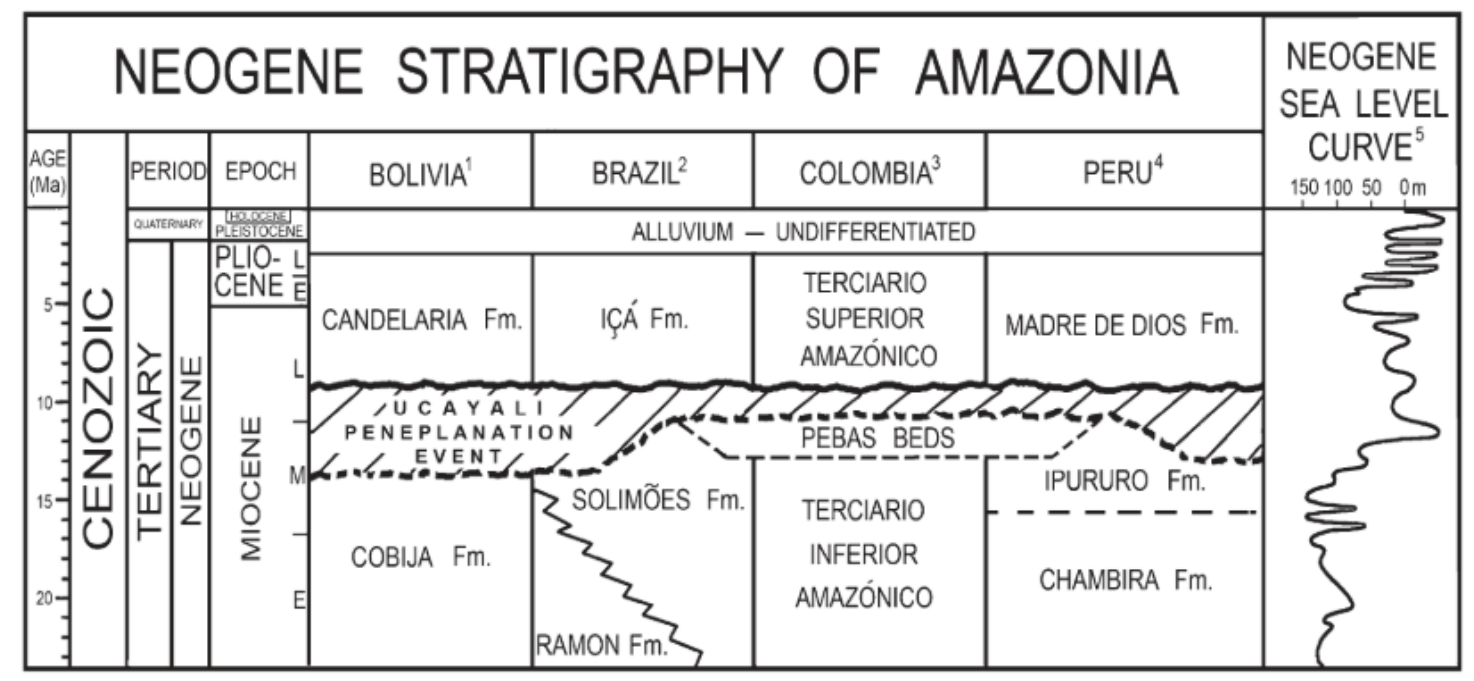

Figure 5 - Correlation chart for the Neogene stratigraphy of Amazonia. The end of the Ucayali peneplanation event is estimated to lie between 9.5 and 9.0 Ma. The end of deposition of the Madre de Dios Formation is estimated to have occurred by $2.5 \mathrm{Ma}$, which corresponds to the second low sea level stand of the PlioPleistocene (Campbell et al., 2006).

Sedimentary records of the Foz do Amazonas Basin exhibit an increase in the sedimentation rate, a change in the geochemical signatures, and appearance of pollen from Andean taxa at the Late Miocene, 10.5-9.4 Ma (Figueiredo et al., 2009, 2010; Hoorn et al., 2017). Sedimentation rates continue to increase at 6.8-2.4 Ma and highly increase by the end of Pliocene 2.5 Ma (Figueiredo et al., 2009). These records base the hypothesis of a Late Miocene origin of the transcontinental Amazon River (Figueiredo et al., 2009; Hoorn et al., 2017), or the recently more refined model with a first Andes-Atlantic connection at 10.1-9.4 Ma and the establishment of the modern Amazon system at 4.5 Ma (Albert et al., 2018).

Correlation of stratigraphical units and events over the Amazon Basin is confuse due to a small spatial representativeness of data. This yields a numerous contradicting or disconnected hypotheses for the evolution and establishment of the Amazon fluvial system (e.g. Campbell et al., 2006; Latrubesse et al., 2010; Rossetti et al., 2015; Hoorn et al., 2017), which highlights the need of a systematized theory embracing the several continental and marine records. 


\subsection{Climate}

Tropical climate of monsoons (Am) and equatorial climate (Af) predominate in the region, according to the Köppen climatic classification. The Amazon region presents seasonal homogeneity of the temperature registering a thermal amplitude on the order of 1 to $2^{\circ} \mathrm{C}$. In Belém, Pará, the average monthly temperatures range between 25 and $26^{\circ} \mathrm{C}$ and in Manaus 25 and $27^{\circ} \mathrm{C}$. The average rainfall in the basin is about $2300 \mathrm{~mm} / \mathrm{year}$ (Fisch et al., 1992; Marengo, 1992). The western high montane and the southern region receives the least rainfall between May and October whereas the northwestern region maintains a wet climate throughout the year where the precipitation can exceed 3600 $\mathrm{mm} /$ year (Marengo, 1992). Seasonality of precipitation increases from north to south and from west to east in the Amazon Basin. The rainfall regime near Manaus is defined by a rainy season between November and May, with higher rainfall in March and a dry season between June and October (Fisch et al., 1992; Marengo, 1992). Evapotranspiration accounts for about half of the produced moisture and the region's rainfall (Leopoldo et al., 1987).

The Intertropical Convergence Zone (ITCZ) is a narrow low pressure belt of convective clouds that constitute the ascending branch of Hadley circulation and strongly controls precipitation over the equatorial region (Waliser and Gautier, 1993). The mean position of the ITCZ, north of the equator, relates to an atmospheric energy balance due to the northward energy transported by the Atlantic's meridional overturning circulation (AMOC), which results in a warmer Northern Hemisphere (Schneider et al., 2014). Over the continent, the branch of ITCZ is broad and irregular, often disconnected from their oceanic counterparts (Waliser and Gautier, 1993). During the austral winter (June-JulyAugust) the ITCZ is displaced northwards causing a dry season in the southern Amazonia and increased rainfall in northern South America and Central America (Figure 6). Between November and March, the southward shift of the ITCZ over northern Amazonia causes an increase in the precipitation over the basin area (Wang and Fu, 2007; Garreaud et al., 2009).

Anomalous elevation of sea surface temperature (SST) in the North Atlantic and weakening trade winds displace the ITCZ to the north, generate periods of drought in the west and south of the Amazon (Espinoza et al., 2011). The El Niño / Southern Oscillation 
(ENSO) events are characterized by interannual climate variability in the Pacific Basin and by elevated SST in the eastern Pacific near western South America (Sandweiss et al., 1996). It is responsible for severe droughts affecting the Amazon, mainly in the central and eastern regions (Williams et al., 2005). The Amazon also plays an important role in southern South America rainfall, the moisture produced over the region is transported southwards and southeastwards by the South Atlantic Convergence Zone (SACZ) (Sachs et al., 2009).

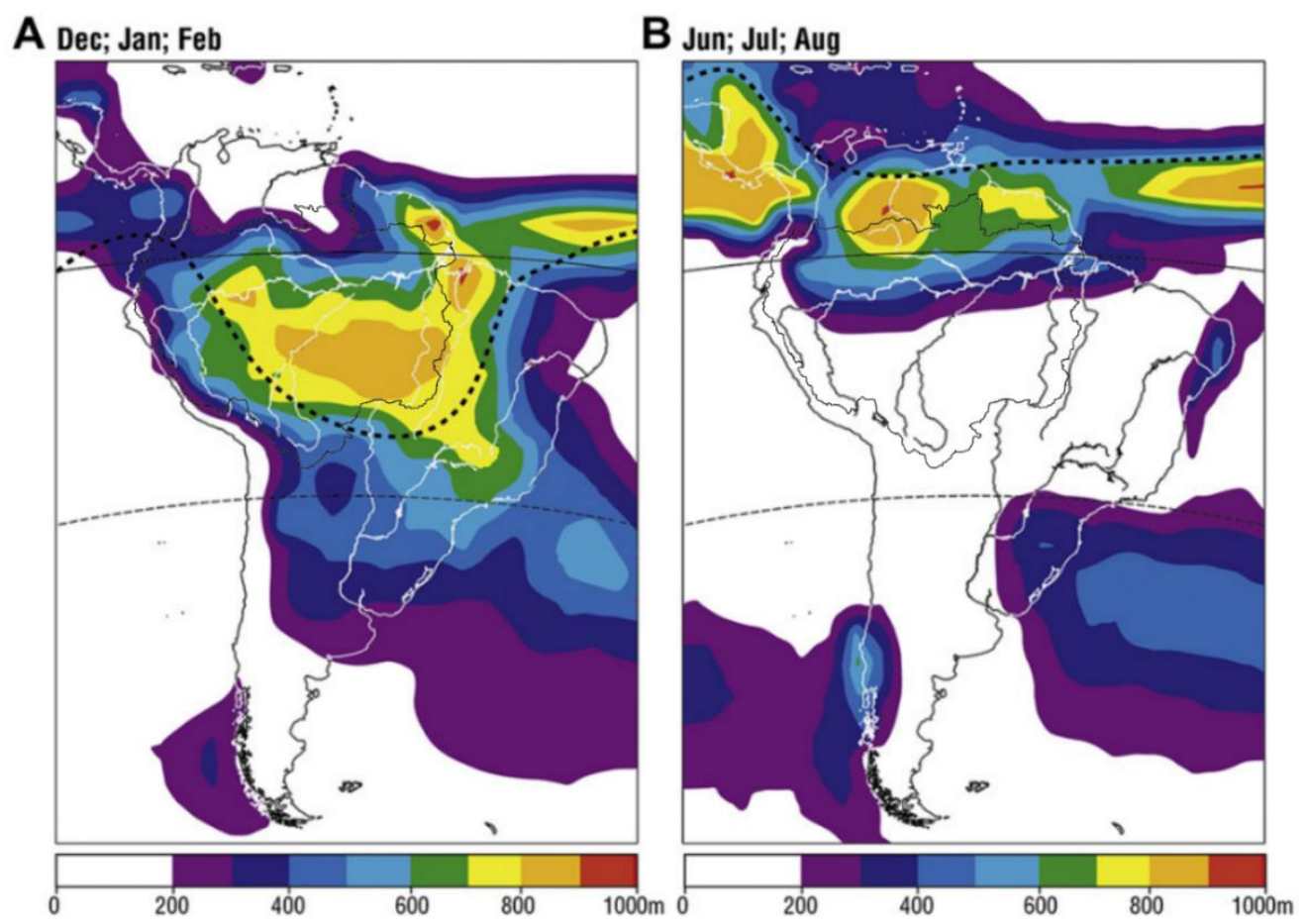

Figure 6 - Modern rainfall in South America. Long-term mean (1979-2000) for December-February (A) and June-August (B). The mean positions of the Inter-tropical convergence zone (ITCZ) are shown in A and B (dashed line) (Maslin et al., 2011).

\subsection{Hydrology}

The history of Amazon is tightly bound to water, as rivers play a crucial role in shaping the relief, mobilizing minerals and nutrients, isolating or connecting biological communities, restricting habitats and dispersing species. The major force driving the biota and biogeochemical processes in these areas are the pulsing of rivers (Junk et al., 1989), and according to simulations made by Miguez-Macho and Fan (2012) flooding occurs over almost a fifth of the basin area (Figure 7). The flood regime is marked by a period of lower 
water level between October and December (drought), followed by the flooding phase from December to June, then reaches its maximum level during May to July and ebbing from July to October / November (Leopoldo et al., 1987; Hess et al., 2003).

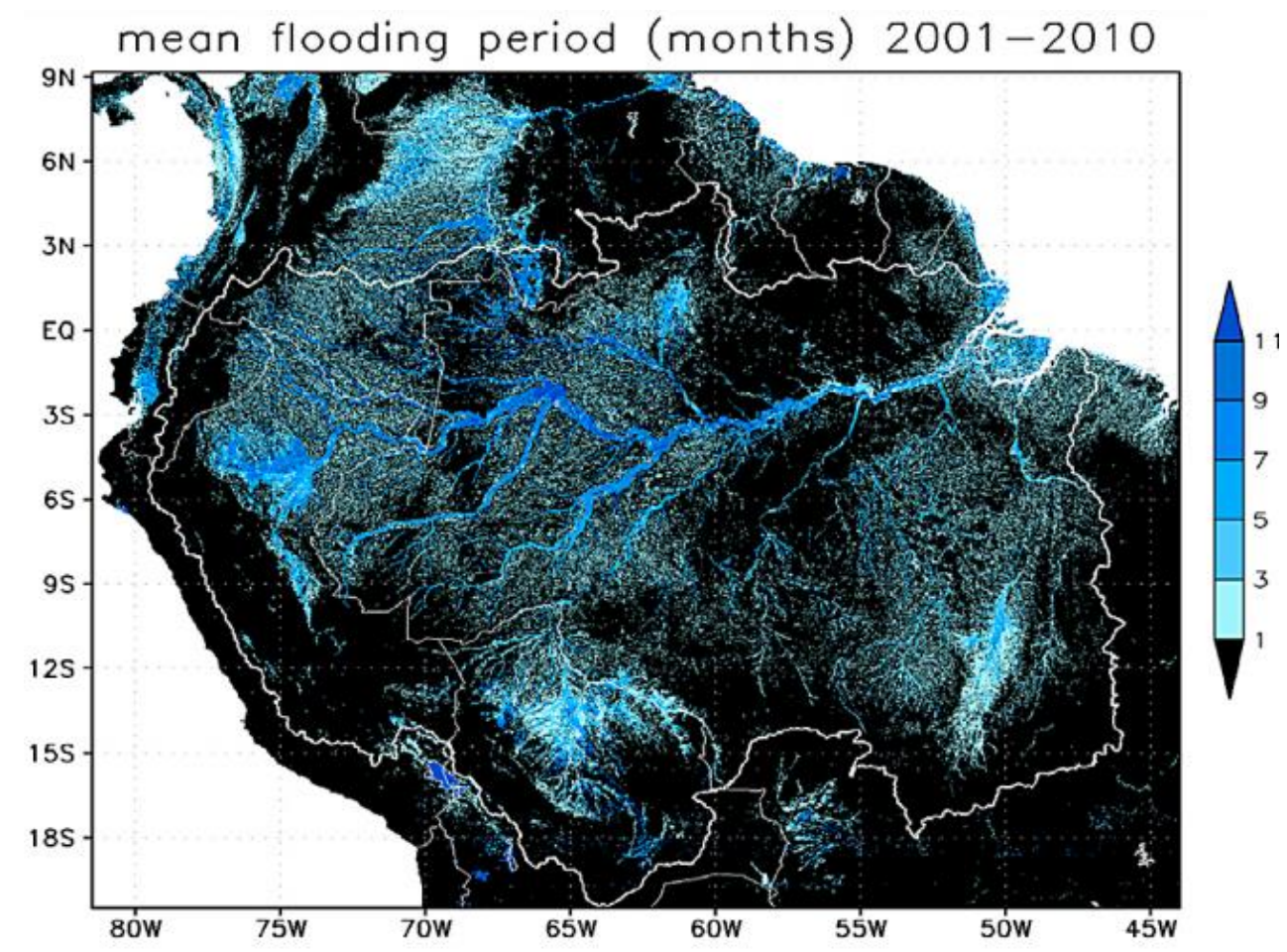

Figure 7 - Flooding frequency as number of months per year over the 10-year period of 2001-2010 (Miguez-Macho and Fan, 2012).

Wallace (1889, apud Archer, 2005) first classified rivers based upon optical proprieties, including whitewater, which is turbid and muddy, blackwater, which lack an inorganic suspended load but have humic compounds, and clearwater, which lack both suspended materials and humic compounds (Figure 8) (Sioli, 1984; Archer, 2005). This classification has proven very useful as biological communities are strongly influenced by hydrological aspects (Prance, 1979). 


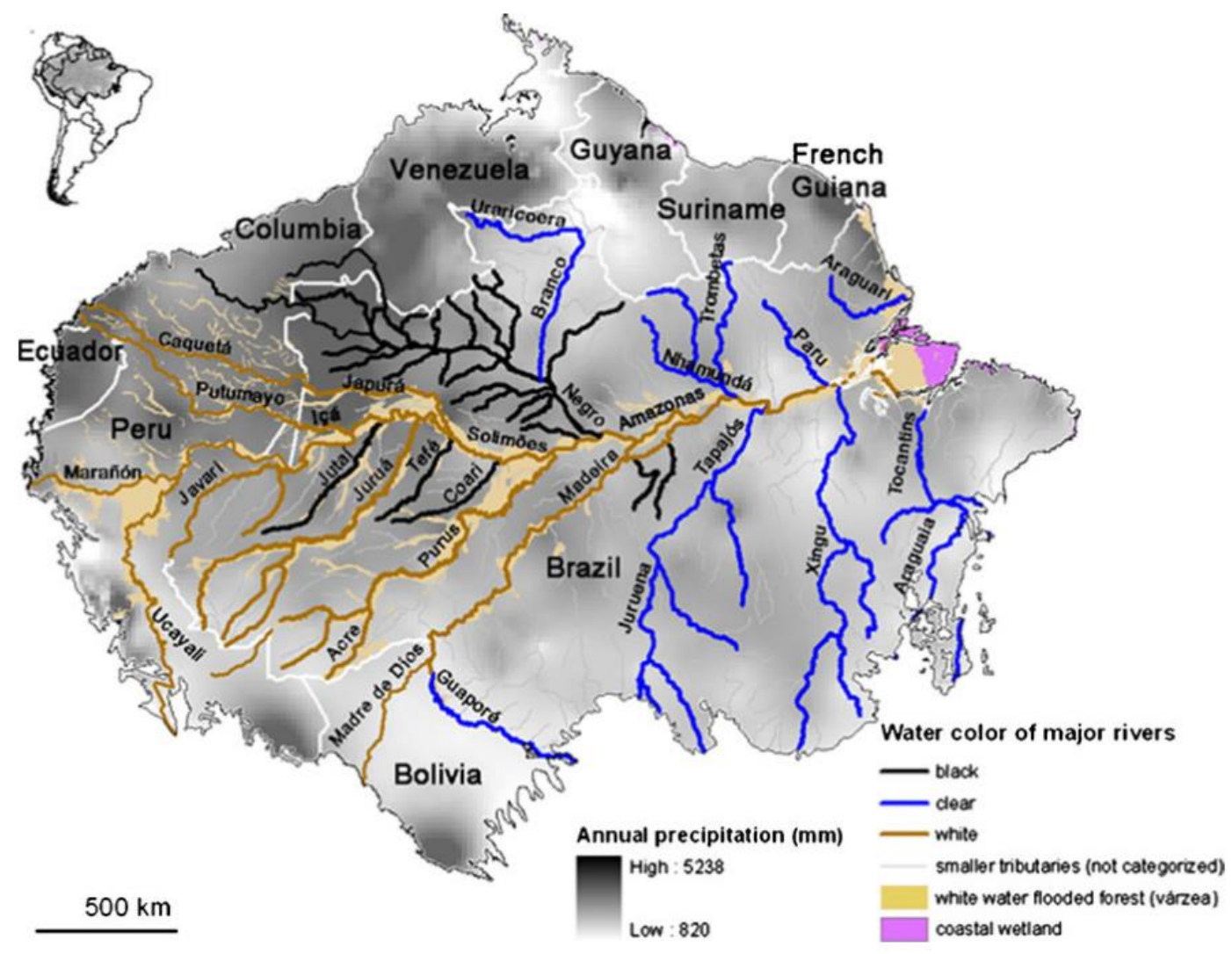

Figure 8 - The distribution of major whitewater, blackwater, and clearwater rivers in the Amazon basin (Junk et al., 2011)

\subsubsection{Whitewater Rivers}

Whitewater rivers include the Amazon River and tributaries such as Içá, Japurá, Juruá, Purus and Madeira rivers. Their waters have neutral $\mathrm{pH}$ and relatively high levels of dissolved solids (Sioli, 1984; Junk et al., 2011). Nutrient-rich sediments brought from Andean regions to the lowlands are deposited in large fringing fertile floodplains, termed várzeas (Pires and Prance, 1985). In montane regions under humid climate, rivers carve steep valleys in $\mathrm{V}$, and processes of mechanical erosion act to feed the drainage with large amounts of debris that are then transported to the lowlands (Sioli, 1984). About $90 \%$ of the sediment discharged by the Amazon River to the Atlantic Ocean is derived from the Andes and nearly half via Madeira River (Meade, 1994). When the Andean-born tributaries enter the lowlands, they develop strong lateral incision, form wind meanders and produces elevated erosion rates (Sioli, 1984; Salo et al., 1986). In whitewater 
floodplains, vertical accretion is constant as well as the development of landforms such as scroll-bars, relict meanders, levees, back swamps, and floodplain-lakes (Archer, 2005).

\subsubsection{Blackwater Rivers}

Blackwater rivers, such as Negro, Coari, and Tefé, are born and drain in the lowlands itself. Dark, transparent and acidic waters are characteristic due to practically absent suspended matter and high concentrations of humic and fulvic acids which give the distinct color (Sioli, 1975, 1984). These black waters originate from lowland podsols, soils of white bleached sands over which develops an open vegetation called campinarana (Sioli, 1975). The lack of alluviation and extensive plant stabilization result in more stable riverbanks, occupied by igapó forests (Pires and Prance, 1985; Archer, 2005). Rias form at the lower reaches of blackwater rivers due to reduced potential for vertical accretion and capacity to keep pace with base-level rise.

The Negro River, the second largest river in the world, transports large amounts of dissolved organic carbon and just a small amount of suspended sediments (Meade, 1994). The watershed of Negro River drains the sedimentary basin and the Precambrian Guyana Shield via Branco River, transporting sand and fine sediments to the Negro River, altering its physical-chemical proprieties. Two of the largest fluvial archipelagos in the world occur in Negro River, Mariuá and Anavilhanas, respectivelly located in the middle and lower reaches of the river (Archer, 2005; Junk et al., 2011; Scudeller and VegasVilarrúbia, 2018).

\subsubsection{Clearwater Rivers}

The most voluminous clearwater tributaries, such as Tapajós (Photo 2), Xingu, and Tocantins, originate in the Brazilian Shield and their watersheds drain part of the cerrado domain of Central Brazil. Clearwater rivers have colorless waters due to the lack of humic matter and to minute amounts of suspension loads (Sioli, 1984). Similarly to blackwater rivers, these rivers lack alluvial valleys, have relatively stable riverbanks with practically absent floating plants, and are margined by an igapó forest. Water acidity is variable and depends on the geological substrate, varying from $\mathrm{pH} \sim 4.5$, in zones of Tertiary 
sediments, reaching up to more than 7 in the Carboniferous rocky strips (Jacobs et al., 1975; Archer, 2005; Junk et al., 2011).

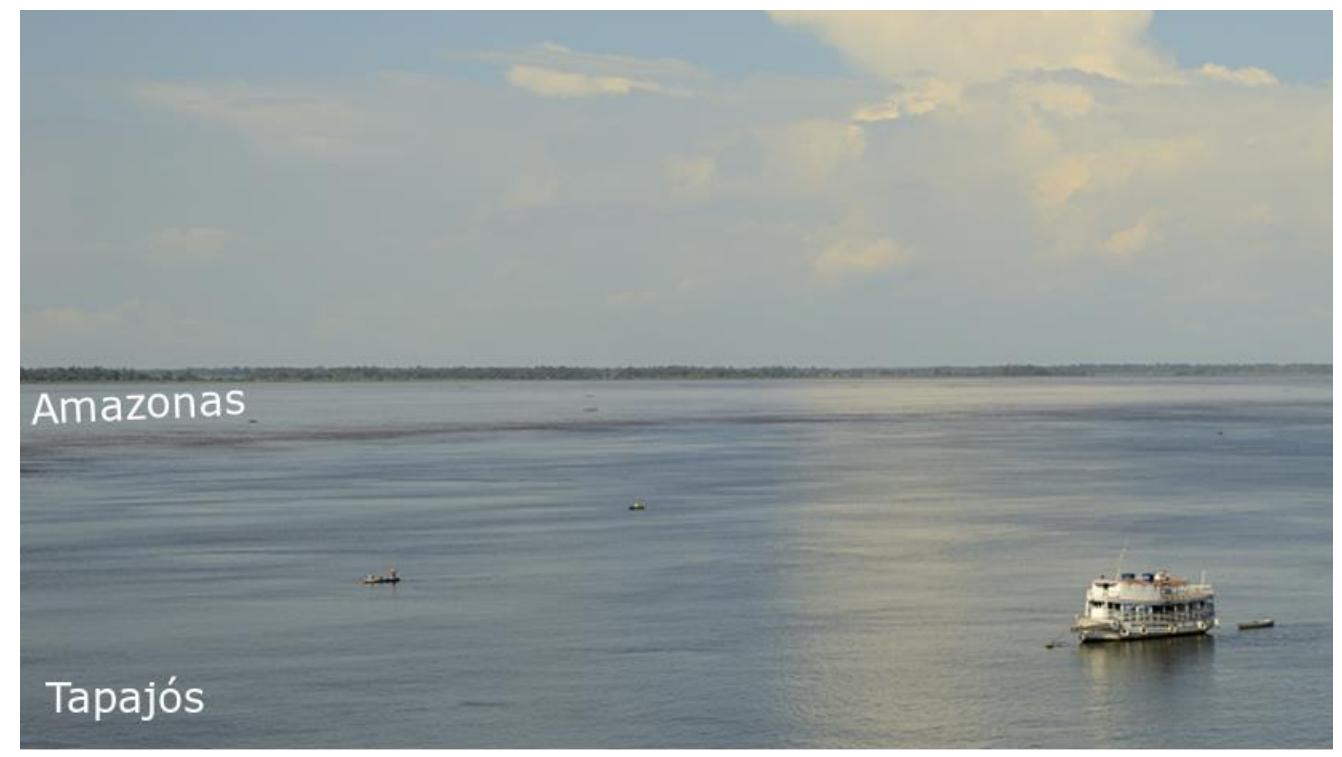

Photo 2 - Confluence of the Tapajós and Amazon rivers. Photo: Thomas Akabane.

\subsection{Geomorphology}

The landscape along the Amazon River distinctly changes due to the interaction with geological substrates and entering tributaries. The western rivers meander in a widestretching lowland, whereas between the Negro River and Amazon estuary, the Amazon River flows in a valley, $20-100 \mathrm{~km}$ in width, margined by the edges of the terra firme (Sioli, 1984).

According to Mertes et al. (1996), the upstream reaches of Solimões River are characterized by a sinuous channel, and high rates of bank and island erosion that promote smaller streamlined lakes disconnected from the main channel and by short-lived islands. The scroll-bar topography tends to channelize floodwater into floodplain drainage channels. Downstream, the river tends to be straighter with slower migration rates, exhibits less scroll bars and larger islands and lakes. In the middle reaches between the Madeira and Tapajós Rivers, the Amazonas River is fairly straight, migrates slower, the floodplains are flatter and covered by hundreds of broad, shallow, patchy lakes, where scroll-bars and levees are constantly buried by overbank deposition. The eastern-most reach of the Amazonas, the delta plain, extends downstream of Tapajós confluence to the 
estuary, where the number and size of islands and lakes decrease dramatically, and the main channel remains straight and locked in position (Figure 9).

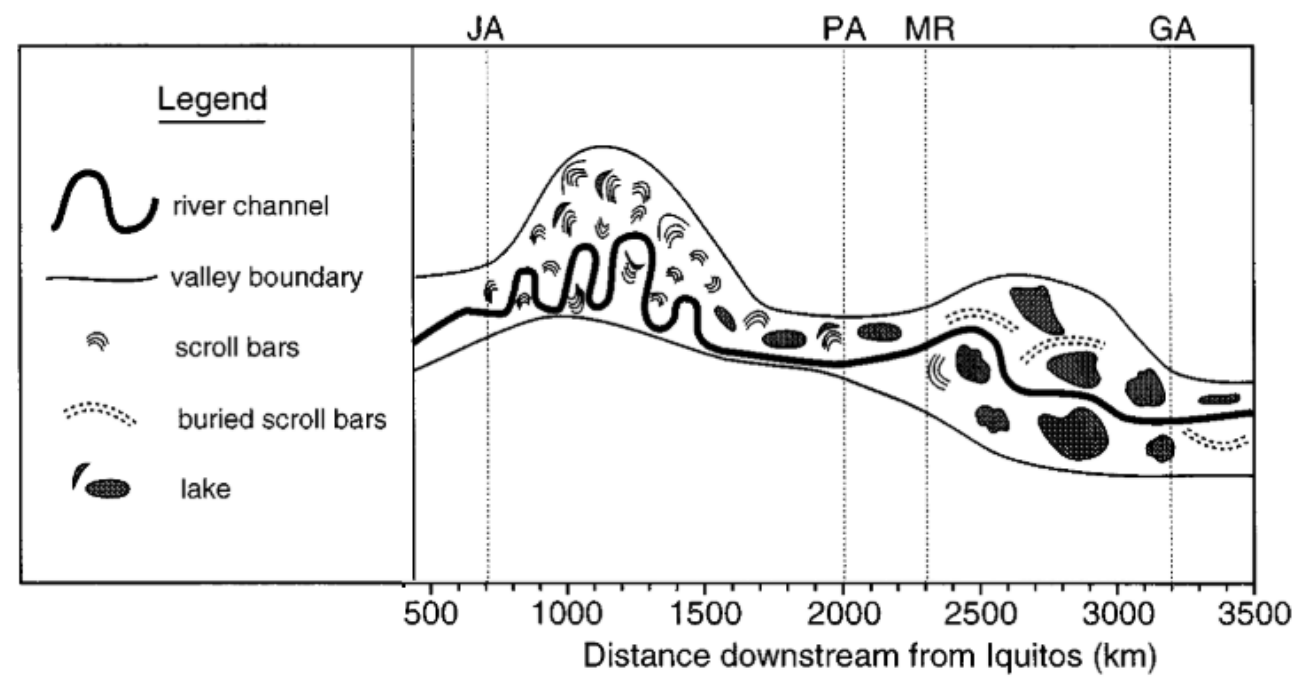

Figure 9 - Schematic illustration of observed along-stream pattern of channel-floodplain geomorphology and valley width. JA—Jutaí arch, PA—Purús arch, MR—Madeira River confluence, and GA—Gurupá arch (Mertes et al., 1996).

Colonization by plants takes place on built fluvial landforms that include scroll bars, islands, levees (Photo 3), lakeshores, drainage channels, and lake deltas. Each of these landforms would experience a slightly different inundation sequence of water flow, sediment transport, and nutrient supply, promoting greater vegetation diversity (Mertes et al., 1995).

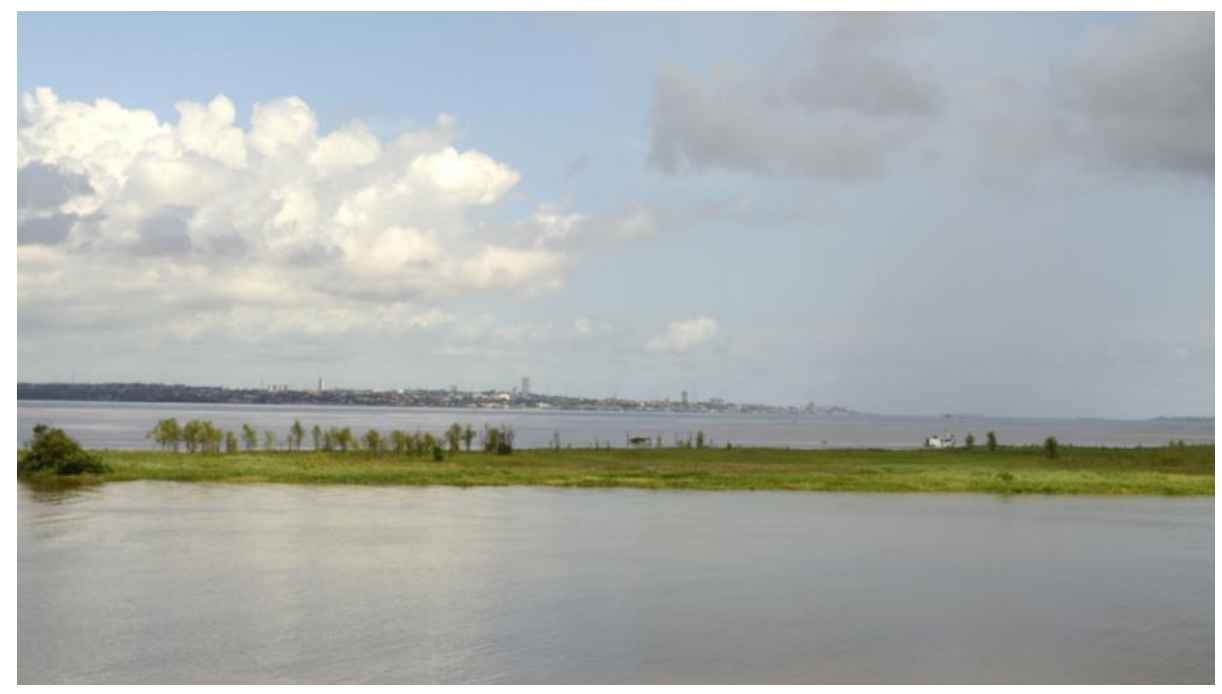

Photo 3 - Vegetated levee at the Amazonas-Tapajós confluence. Photo: Thomas Akabane. 
The Amazon River presents a strong seasonal water level fluctuation that is result of the rainfall in its headwater zones, which oscillate in intensity throughout the year between the northern and southern tributaries. The resultant water discharge from the tributaries cause a maximum inundation level generally reached in May, and the lowest water level in October-November (Sioli, 1984; Leopoldo et al., 1987). The differences between highest and lowest water levels may reach up to $20 \mathrm{~m}$ in the upstream reaches of Solimões; near Manaus this amplitude is 10-12 m. After the Negro River confluence, the flood amplitude continually decreases to about 6-7 m near Santarém. At the Estuary the amplitude is $2-3 \mathrm{~m}$ and there is a growing influence of ocean tides that are felt as far as about $1000 \mathrm{~km}$ upstream (Sioli, 1984) (Figure 10).

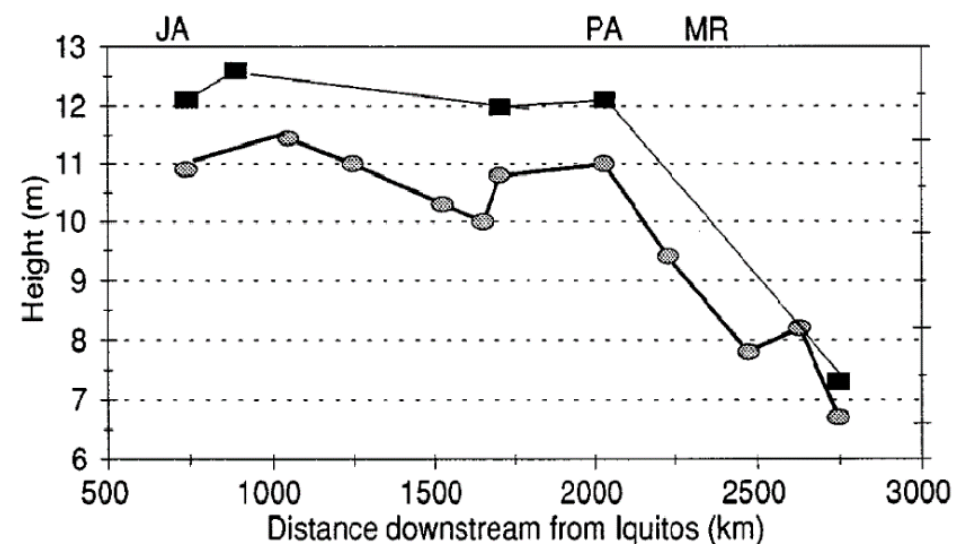

Figure 10 - Flood amplitude in the Amazon River. Dots indicate bank height with respect to low water, and rectangles indicate the maximum flood height based on the difference between the lowest and highest river stage along the Amazon River. JA = Jutaí Arch; PA = Purus Arch, MR = Madeira River (Mertes et al., 1996).

Some tributaries, as Xingu, Tapajós, Negro, Coari, and Tefé rivers, exhibit a sudden enlargement in their lower reaches, forming an elongated lake-like aspect called ria (Figure 11). In these areas, the current slows down and the capacity of transport is reduced. Some of these forms are the result of dammed up water bodies that have filled and drowned their original river valleys, probably as consequence of erosion followed by the rise of the ocean level at the end of the last glacial period (Sioli, 1984), or related to neotectonic reactivation (Bertani et al., 2015). 


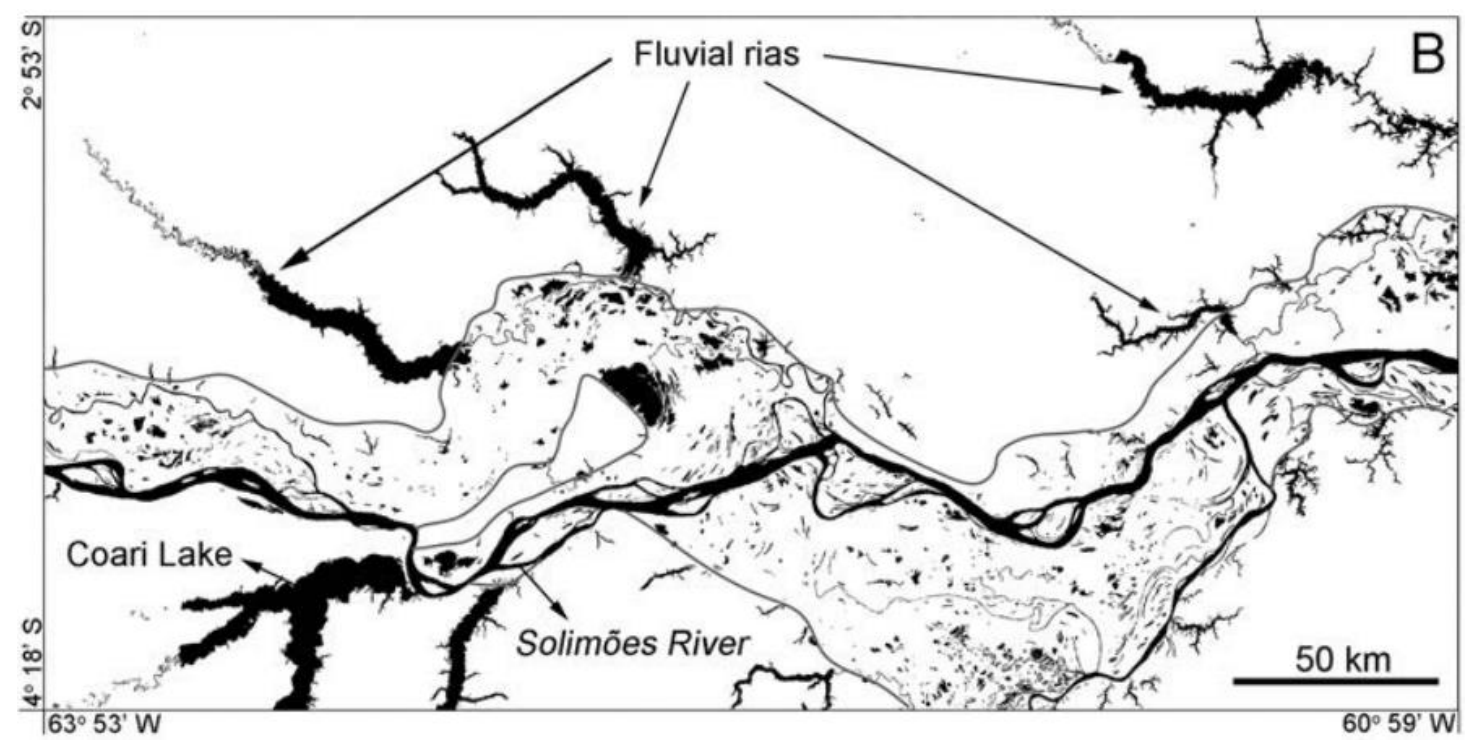

Figure 11 - Modern fluvial rias in the Solimões River floodplain (Bertani et al., 2015).

\subsection{Vegetation}

Amazon forest hosts an array of the most diverse plant communities in the world, although most of them are still poorly known. The Western Amazon is thought of as a biodiversity hotspot, where high densities of about 300 arboreal species per hectare were registered (Gentry, 1992). This exuberant Amazon tropical forest is the result of a sum of various environmental conditions that permit dense vegetation to thrive. Under the warm and humid equatorial climate, competition for water is not so important, whereas competition for light becomes paramount, thus adaptations for reaching light through the forest canopy or for shading competing plants are commonly developed (Pires, 1984). A wide range of variation in species composition and physiognomy relate to geographical distance or local conditions, evident by enclaves or discontinuities in the dense forest canopy (Pires, 1984).

According to Gama et al. (2005) Protium hebetatum and Eschweilera coriacea are some of the most commonly species recorded in Amazon forests. In fact, it has been observed that a few oligarch species show high frequency, locally abundance, and usually dominate in different parts of Amazônia (Pires and Prance, 1985; Pitman et al., 1999, 2001). Ter Steege et al. (2013) data show that about $1.4 \%$ of hyperdominant tree species account for half of all trees, whereas the rarest 11,000 species account for just $0.12 \%$ of trees. Some of the hyperdominant taxa include species belonging to the arboreal genera 
Euterpe, Protium, Eschweilera, Pseudolmedia, Iriartea, Eperua, Hevea, Attalea and Licania. The arboreal families that usually exhibit more frequent hyperdominant species are Arecaceae, Myristicaceae, Lecythidaceae, Sapotaceae, and Burseraceae (ter Steege et al., 2013; Silva et al., 2016).

Relief has an important role in determining watercourse and shaping rivers, which affect the vegetation composition. Accordingly, there are two principal ecosystems, the terra firme, which comprises the non-flooded lands, and the várzea (floodplain), occupied by the inundated forest. Terra firme hosts most of Amazonian diversity, while the conditions of várzea restrict the occurrence of flood intolerant species (Wittmann et al., 2006). Despite the fact that many of the Amazonian várzea tree species are also found in adjacent moist terra firme, the opposite is not true (Gama et al., 2005; Scudeller, 2018). Other factors that control vegetation include fire frequency, soil-water deficits during the dry season (i.e., seasonality), and human activity (Hess et al., 2003; Gama et al., 2005).

\subsubsection{Terra Firme}

Terra firme refers to the non-flooded uplands, which covers over 5 million $\mathrm{km}^{2}$ of the Amazon and concentrate the richest amazonian vegetation diversity with high occurrence of rare plant species (Pires, 1984; Silva et al., 2016). The most important tree families in neotropical terra firme forests are (with decreasing importance): Fabaceae, Moraceae, Annonaceae, Euphorbiaceae, Lauraceae, Sapotaceae, Myristicaceae, and Arecaceae (Wittmann et al., 2011). Pires and Prance (1985) sub-classify terra firme vegetation in Dense Forest, Open forest without and with palms, Liana forest, Dry forest and Montane forest, described below.

Dense forest is the physiognomy with the greatest biomass and occurs where environmental conditions are optimal and where there is no limiting factor of excess or scarcity of water. This physiognomy is characterized by a cleaner understory, with a diversity of lianas climbing directly to the crown (Photo 4) and lack of shrubs, vines, grasses, and sedges between the trees (Pires, 1984; Pires and Prance, 1985).

In the Open forest without palms, the biomass is lower and the trees are smaller, consequently, sunlight can penetrate allowing shrubs and lianas to develop well and cover the forest floor. A lower water table, long dry season or edaphic aspects promoting water 
stress conditions cause this lower biomass. The open forest with Attalea and Euterpe palm species, and frequently with a large number of Brazil nut trees (Bertholletia excelsa) in certain areas, is similar to the former in density and tree height (Pires and Prance, 1985).

The Liana forest comprises a variety of open forest types that have an abundance of lianas or climbing vines usually forming a complex mosaic with dense forest types, where plants to reach the upper canopy adopt several strategies. Some important families of lianas are Fabaceae, Bignoniaceae, Malpighiaceae, Dilleniaceae and Menispermaceae (Pires and Prance, 1985).

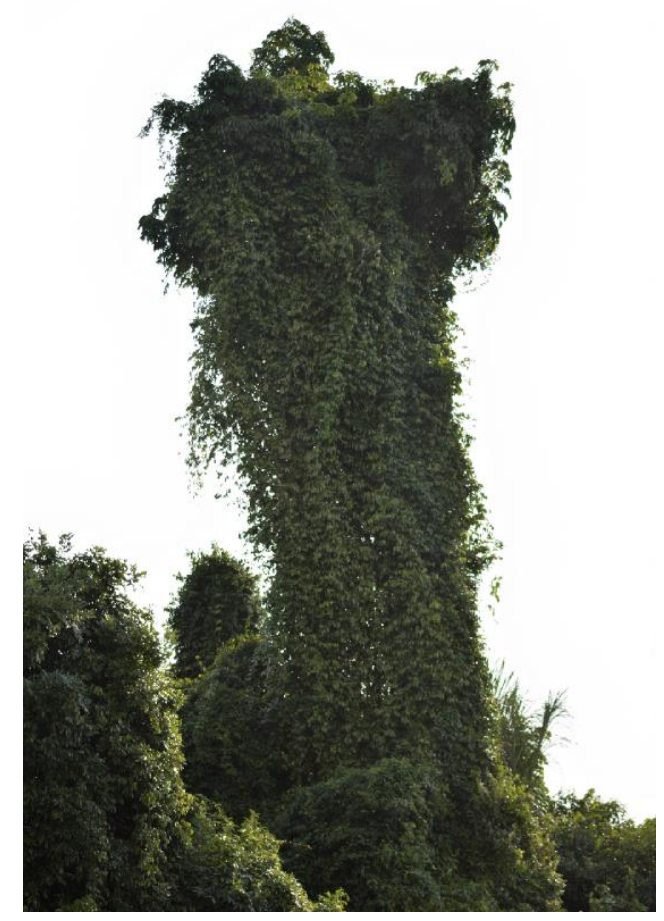

Photo 4 - Tree draped in lianas at Altamira, Pará, region. Photo: Thomas Akabane.

Dry forest occurs as a transitional vegetation type, occasionally found in the southeastern Amazon, due to higher seasonality and lower relative humidity. Some common species there are Cenostigma macrophyllum, Combretum leprosum, Bowdichia virgilioides, Vochysia haenkeana and Attalea speciosa (Pires and Prance, 1985).

Terra firme savannahs also occur in Amazonia, physiognomically very similar to the cerrados of Central-brazil, cover about $3-4 \%$ of the Brazilian Amazonia and include 
species typical of cerrados, such as Curatella americana, Byrsonima crassifolia, Tabebuia caraiba (Pires and Prance, 1985). Near Santarém and Monte Alegre, these open areas are locally called capoeiras (Photo 5).

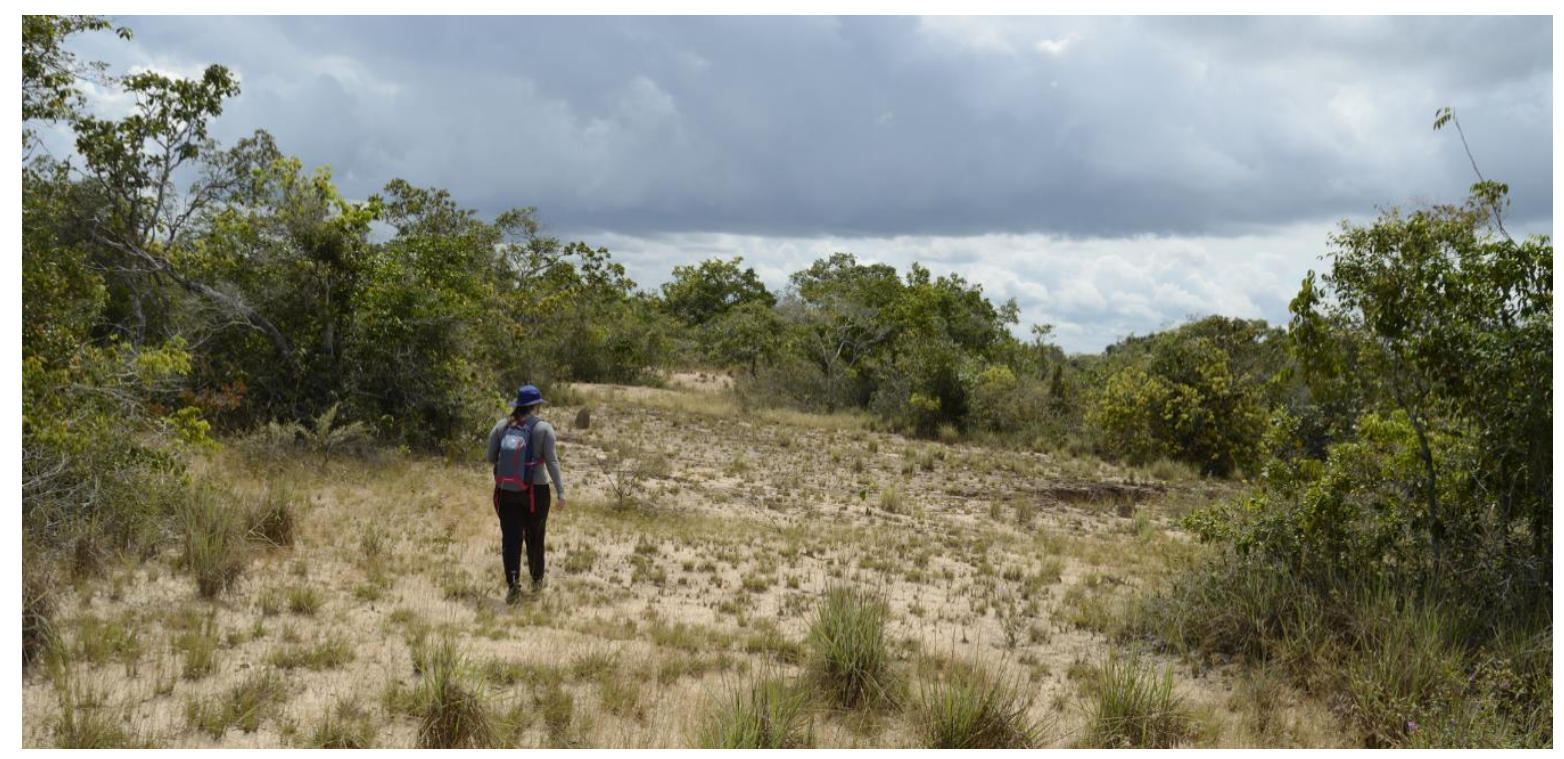

Photo 5 - Open vegetation edaphically restrained, locally called capoeiras, near the city of Monte Alegre,

Pará. Photo: Thomas Akabane.

Mountainous regions occur to the northern Amazon boundary between Roraima, Venezuela and Guyana, and to the western boundary at the Andean region. Although humidity is high on steeper slopes, shallow and rocky soils hinder water retention and induce drought even in short dry periods of the year. As altitude increases, the biomass usually diminishes and trees become smaller. Some examples of important families in these regions are Theaceae, Bromeliaceae, Eriocaulaceae, Poaceae, Ericaceae, Cunoniaceae, Winteraceae, Podocarpaceae and Betulaceae (Pires and Prance, 1985).

At Northeast Roraima and part of Guyana, the wide-open vegetated area of savannahs are locally called 'Lavrado' in Brazil (Photo 6). A different phitophysignomy also occur in this region, known as campos rupestres (rocky fields). The savannahs in this area have numerous lakes or patches of swamp where monospecific stands of Mauritia flexuosa occur, known as veredas or buritizais (Pires and Prance, 1985). 


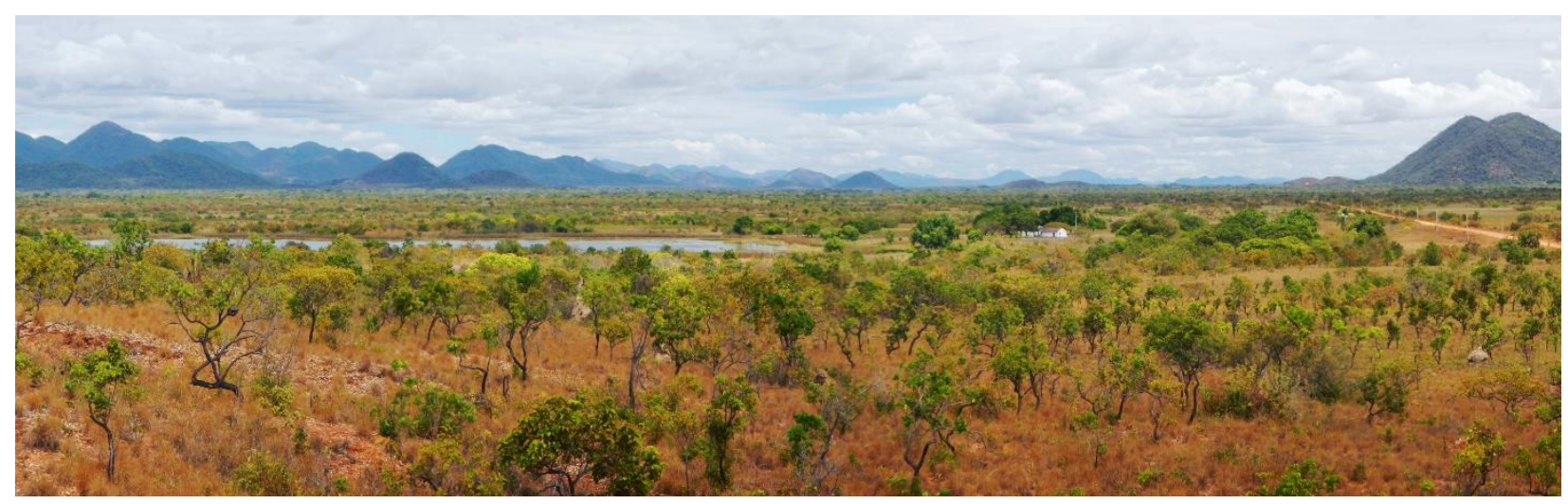

Photo 6 - Open vegetation of northeast Roraima, Lavrado, Pacaraima. (Photo: André Stern)

\subsubsection{Flooded vegetation}

Floodplains of whitewater rivers, rich in suspended sediments, are called várzea, and those inundated by black or clearwater rivers are called igapó. Difference in the water property that lave the floodplain directly impacts the vegetation in terms of available nutrients, humic matter, and soil acidity (Prance, 1979; Sioli, 1984). The terminology for describing these vegetation types are vast and many subdivisions can be made (Prance, 1979; Pires and Prance, 1985), however, here just the major classifications according to water-type and flood duration are used.

Amazon biological communities along floodplain systems may be explained by the pulse concept, which states that the predictable seasonal flooding regime (flood pulse) is the major force controlling the biota and biogeochemical processes in these areas (Junk et al., 1989). The flood pulse is pointed as a great factor influencing forest distribution, succession (e.g. Montero and Latrubesse, 2013; Wittmann et al., 2006, 2002; Wittmann and Junk, 2003; Worbes et al., 1992), and species differentiation (Kubitzki, 1989).

At high-várzea, floristic dissimilarity significantly increases with increasing geographical distance, whereas the low-várzea can exhibit high similarity over large distances. This similarity might be related to the connectivity of riparian corridors, which leads to similar, vertically arranged ecological niches across remote várzea forests (Wittmann et al., 2002, 2006). However, this similarity is not observed in other regions, such as the igapó forests of Negro River, where the communities form mosaics, and environmental factors (e.g., soil texture or height and duration of flooding) may act as filter for species distribution (Montero et al., 2014). 


\subsubsection{Várzea}

Várzea forests contain fewer species than their non-flooded counterparts, nevertheless, are the world's most species-rich wetlands (Wittmann et al., 2006). Flooding occur for about 5 months during the rainy season and the vegetation is strongly controlled by land gradient and period of submersion during inundation; therefore várzea can be classified in terms of length and height of inundation. Low-várzea forests establish where the annual water column has an average height greater than $3 \mathrm{~m}$ and inundation period exceeds 50 days/year (Martinez and Le Toan, 2007). In this case, forest structure depends on the successional stage, as species diversity increases with increasing age of the formations. High-várzea forests occur where the annual water column averages less than $3 \mathrm{~m}$ in height and less than 50 days/year, and consist of late successional forests that occupy the transitional zone between flooded and non-flooded sites (Wittmann et al., 2011). The ecological succession processes follow a pattern that is governed by the exposition of vegetation communities to the flood. (Martinez and Le Toan, 2007). At the middle reaches of the Amazon River, semi-aquatic vegetation, tree-like aquatic plants (e.g. Montrichardia arborescens) (Photo 7), and shrub-like trees (e.g. Salix sp. and Courupita guianensis) can colonize regions flooded for more than 300 days/year. Secondary colonizers, such as tall well-developed floodplain forest taxa, cover regions flooded for approximately 150 days/year, and floodplain climax forest colonize regions inundated for less than 60 days/year (Costa, 2004)

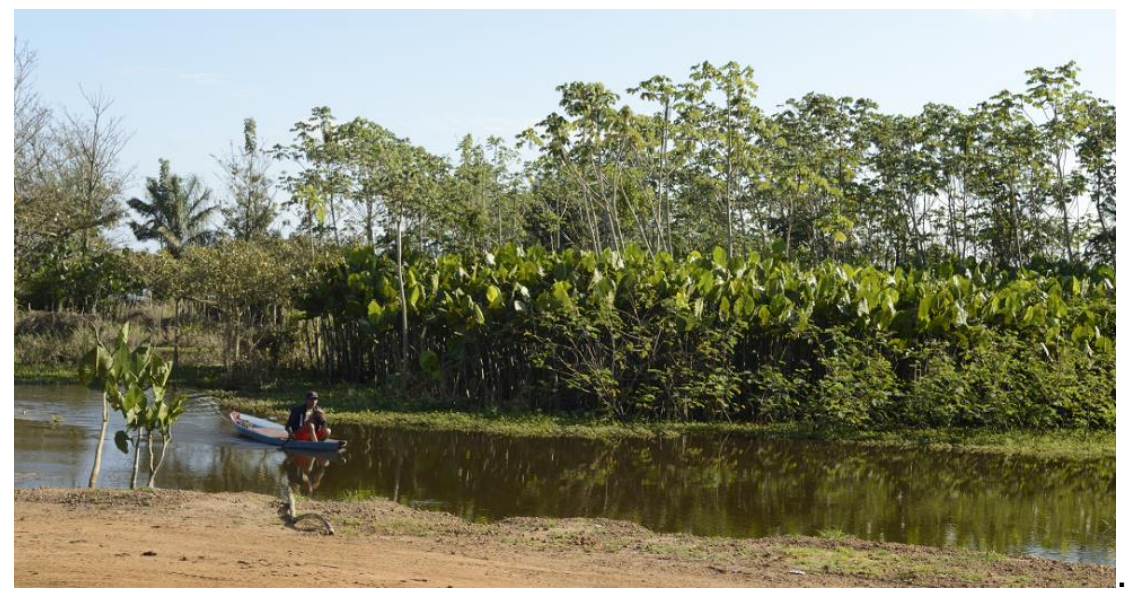

Photo 7 - Stands of aninga (M. arborescens) and embaúba (Cecropia sp.) on the Amazon River margin, at Distrito Portuário de Santana do Tapará, Pará. Photo: Thomas Akabane. 
Due to river activity, erosion and aggradation continually destroy and recreate fluvial forms, and new available areas for plants colonization are in constant generation. According to Salo et al. (1986), about a quarter of the modern western lowland forests have characteristics of recent erosional and depositional activity, and $12 \%$ are in a degree of successional stage (Figure 12). Forest succession starts with few species stands on ridges of point bars and channel bars. This process of increasing biomass of vegetation succession takes place until reaches the climax stage, a theoretical biomass equilibrium point (Pires, 1984). Levees are covered by dense highly adapted floodplain forest, and lowlying and strongly disturbed areas are rapidly colonized by herbs (Junk and Piedade, 1993).

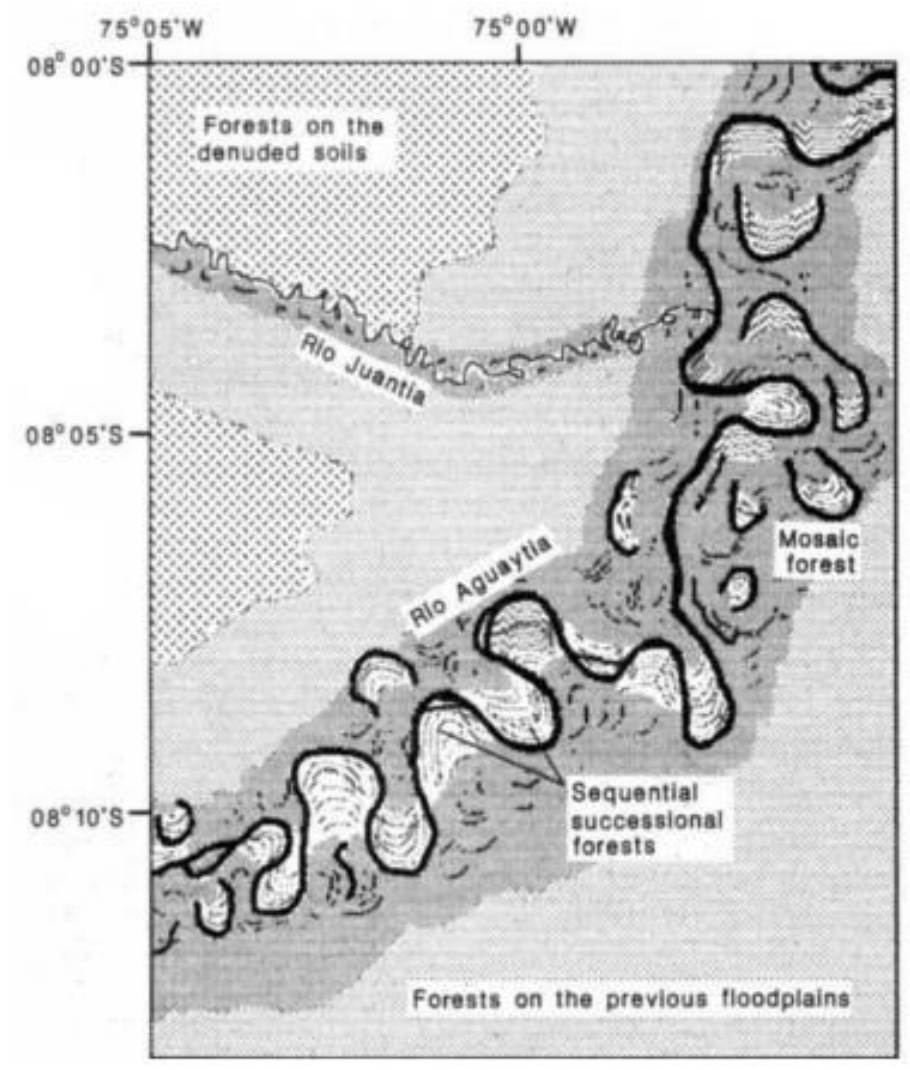

Figure 12 - Successional forest is created on both sides of the meandering rivers. As the meandering proceeds, the sequential successional forest is cut and a mosaic forest structure is created (Salo et al., 1986).

The pioneer flora includes many widespread perennial herbs able to grow over sediments exposed during low water levels (Photo 8), poor in organic carbon and nitrogen. Colonization begins either with immigrant propagules dispersed by wind or water, or with 
the invasion of species by vegetative means (Junk and Piedade, 1993). The most plentiful early vegetation is usually found on fine-textured sediment in distal-bar forms and in chute channels, and includes species members of Poaceae, Asteraceae, Cyperaceae, Onagraceae, Amaranthaceae, Solanaceae, Lamiaceae, Rubiaceae and Piperaceae (Junk and Piedade, 1993). Establishment of a pioneer vegetation promotes sedimentation because stems and roots reduce water current energy and induces the topography of river bars to grow in height, which allows the increment of biomass by a gradual reduction in the flood duration (Junk and Piedade, 1993; Martinez and Le Toan, 2007).

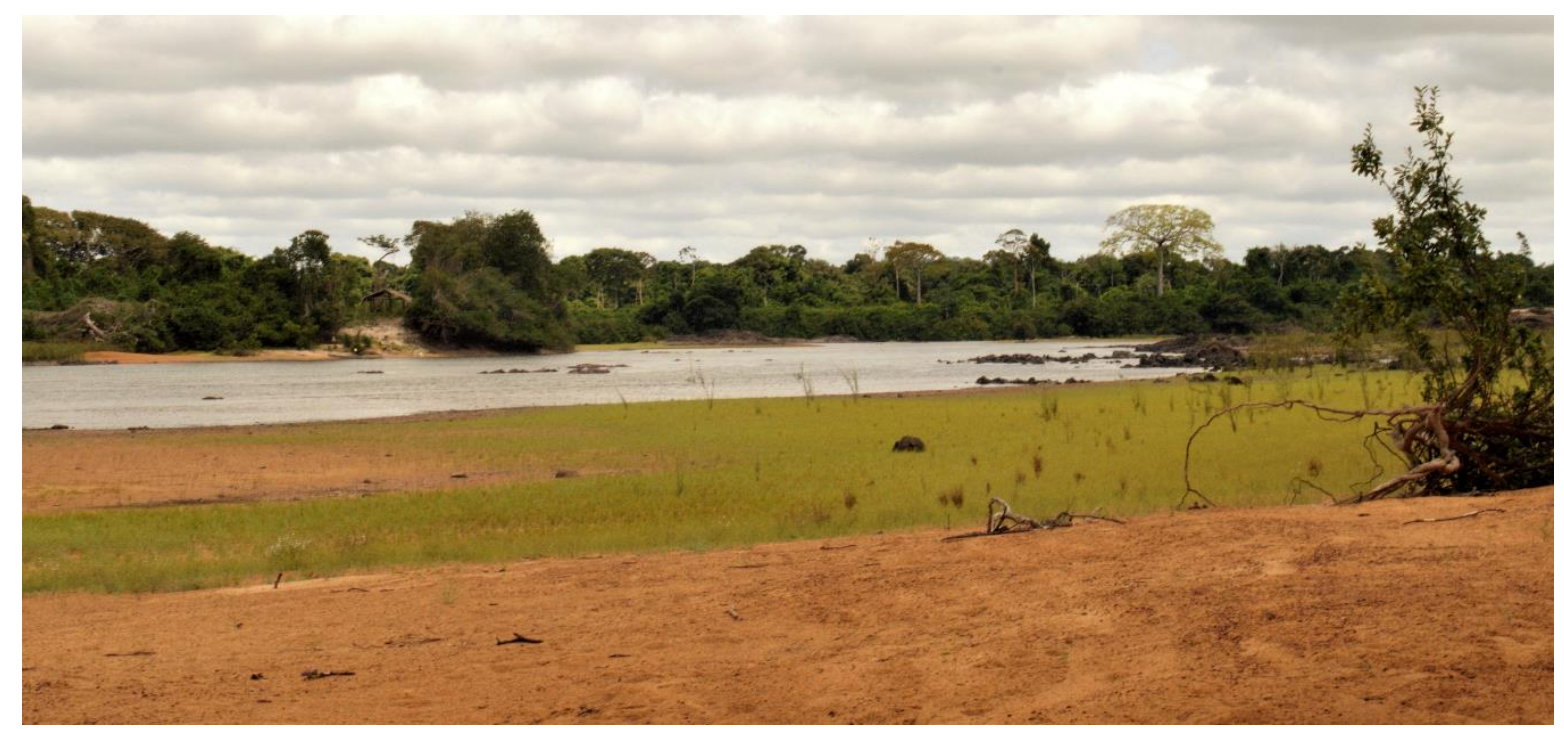

Photo 8 - Grasses growing over exposed lands during low water levels, Iriri River, Pará. Photo: Thomas Akabane.

Várzea savannahs (grasslands) are typical between the mouth of Negro River down to the mouth of the Xingu River, and especially between the Madeira River and the city of Monte Alegre, Pará (Figure 13). Narrow stretches of forest grow on the levees beside the main stem and tributaries, and behind the forests, there are meadows of grass known as canarana. In these formations, several perennial species, notably Paspalum repens and Echinochloa polystachya, adapted to the succession of terrestrial and aquatic phases, rapidly grow as the water rises during the inundation phase. Flood duration limits forest implantation, low vegetation develop in areas flooded more than 252 days a year (Martinez and Le Toan, 2007). A distinct feature of the middle and low Amazonas várzea 
is the presence of several lakes that increase in size during the rainy season and during the dry season, when the water recedes, become covered with grass (Pires and Prance, 1985). Various species of floating plants, grasses, shrubs and vines colonize these areas, exemplified by a diversity of Poaceae and Cyperaceae species, Artemisia, Ipomoea, Polygonum, Alternanthera, Hyptis, Aeschynomene, Mimosa, Cassia, Phaseolus and Clitoria (Pires and Prance, 1985; Junk and Piedade, 1993).

Pioneer stage is succeeded by early-secondary stage, allowing first formation of homogeneous Cecropia latiloba stands followed by the increasing of low-várzea species (Figure 14). In floodplain lakes, the clayey poorly aerated soil and long inundation periods favors early-successional vegetation, such as Symmeria, Eugenia and Cocoloba. Formation of late-secondary forests proceeds only when the flooding length decreases due to building-up and rise of the lake bottom. After the establishment of early-secondary tree species, pioneer herb species no longer regenerate because of competition for light, on the other hand, a canopy cover favors late-secondary tree species by reducing solar radiation (Junk, 1989; Kalliola et al., 1991; Wittmann et al., 2002, 2011).

Late-successional stages near river shores are characterized by upper canopy species, such as Pseudobombax munguba, Laetia corymbulosa and Luehea cymulosa, while those in the lower canopy are Maclura tinctoria, Nectandra amazonum and Crateva benthamii (Worbes et al., 1992). Late-successional forests develop as the age of substrate increases (Kalliola et al., 1991), and are formed by a substantial amount of trees belonging to the upper canopy, at a height of 30-35 m, contrasting with a poorer understory vegetation. Characteristic species in the upper canopy are Piranhea trifoliata, Tabebuia barbata and Hevea spp. and in the lower canopy Pouteria spp., Oxandra spp., and Duroia duckei. Maximum stand ages of approximately 400 years are recorded in tree rings of Piranhea trifoliata, which indicates a climax stage (Worbes et al., 1992; Junk, 1997; Wittmann et al., 2011). 

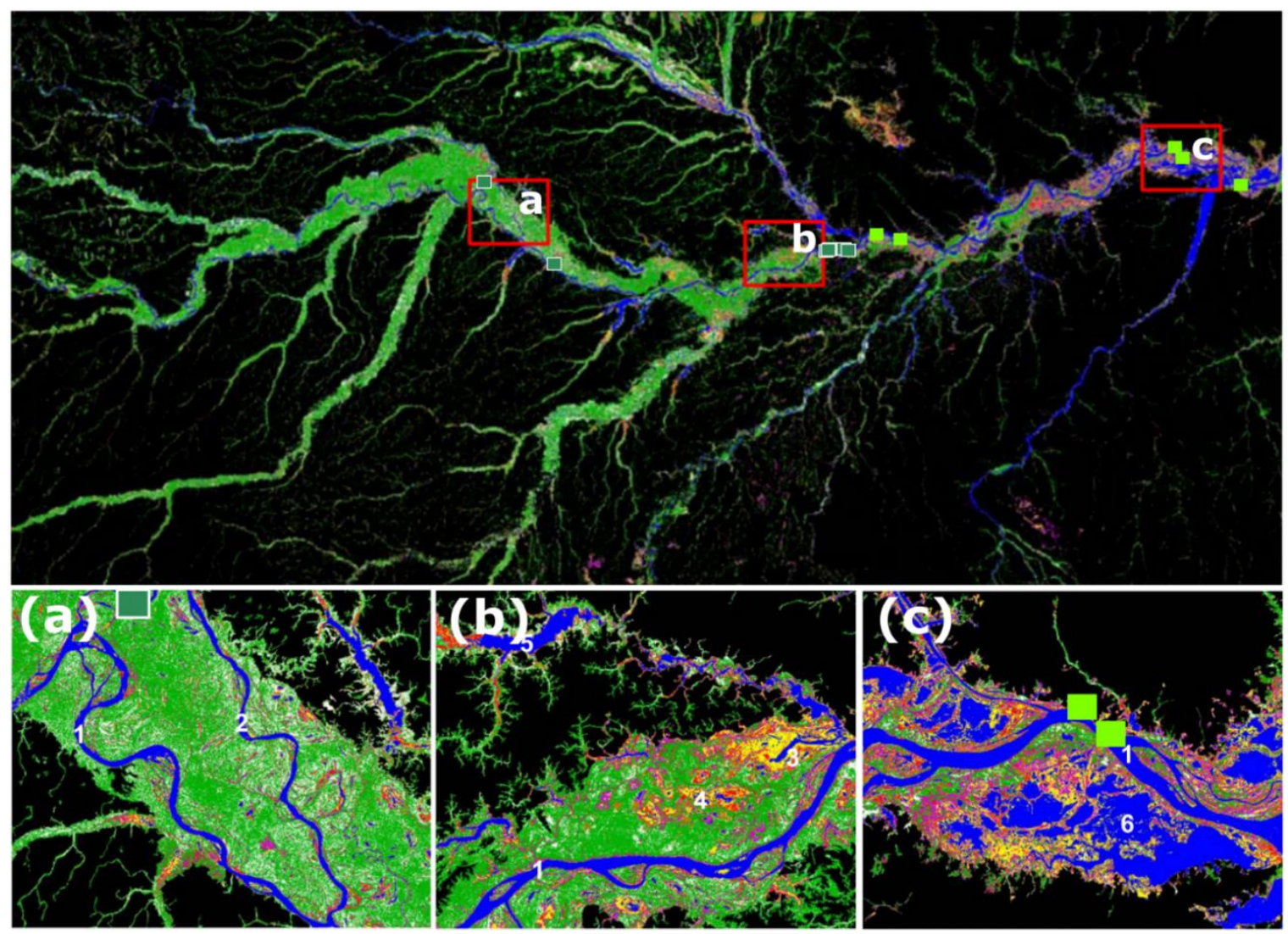

Water

Bare or herbaceous, nonflooded

Herbaceous, flooded

Shrub, nonflooded
$50 \mathrm{~km}$
Shrub, flooded

Woodland, flooded

Forest, nonflooded

Forest, flooded

Figure 13 - Vegetation cover classes at low-water stage, extrated by L-band synthetic aperture radar imagery (adapted from Hess et al., 2003). Green squares represent the samples analysed in the present study.

High-várzea forests establish above a mean flood level of $3 \mathrm{~m}$ and due to the relatively long terrestrial phases, trees regenerate during most of the year, thus leading to a characteristically dense understory. These forests can be considered as the climax stage of successional sequence of várzea (Figure 15) and in central Amazonia, some abundant genera include Terminalia, Aspidosperma, Guarea, Pouteria, Brosimum, Eschweilera, Inga, Duguetia, and Annona (Wittmann et al., 2011). 


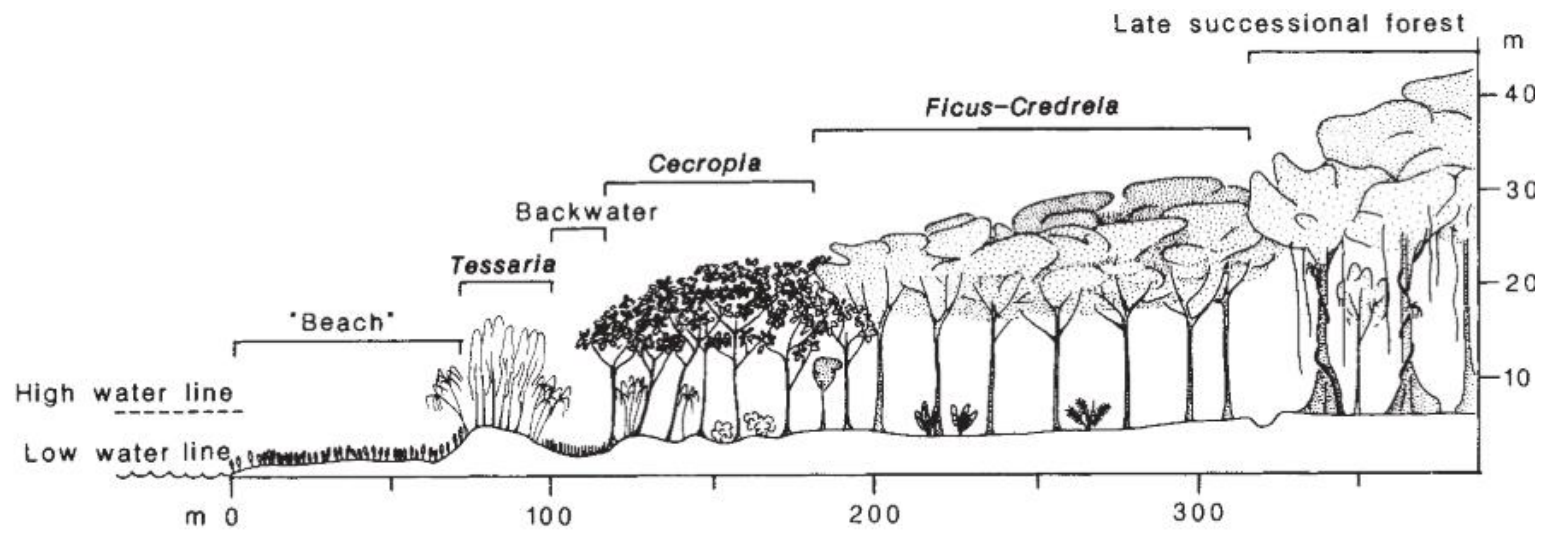

Figure 14 - Riparian succession in the sequential successional flora in a western tributary (Manú River)

(Salo et al., 1986).

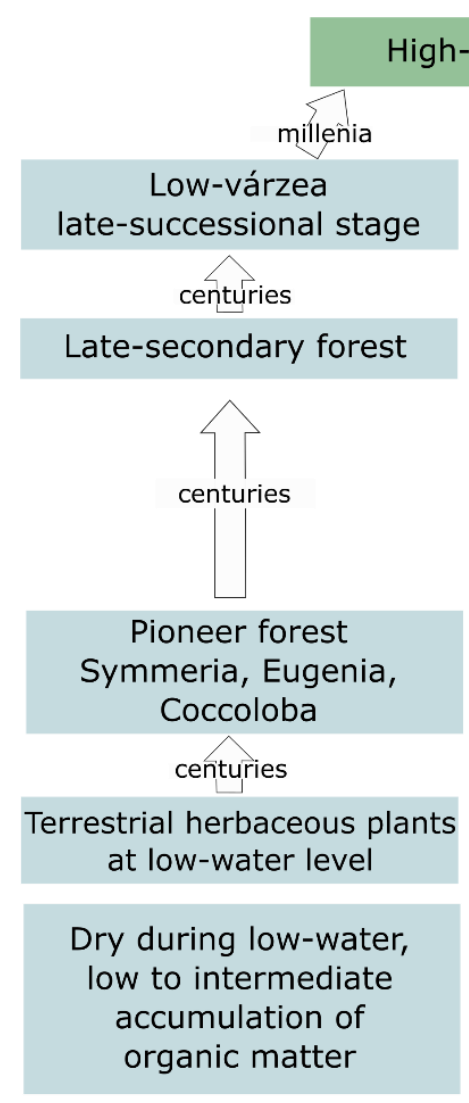

Low sediment deposition

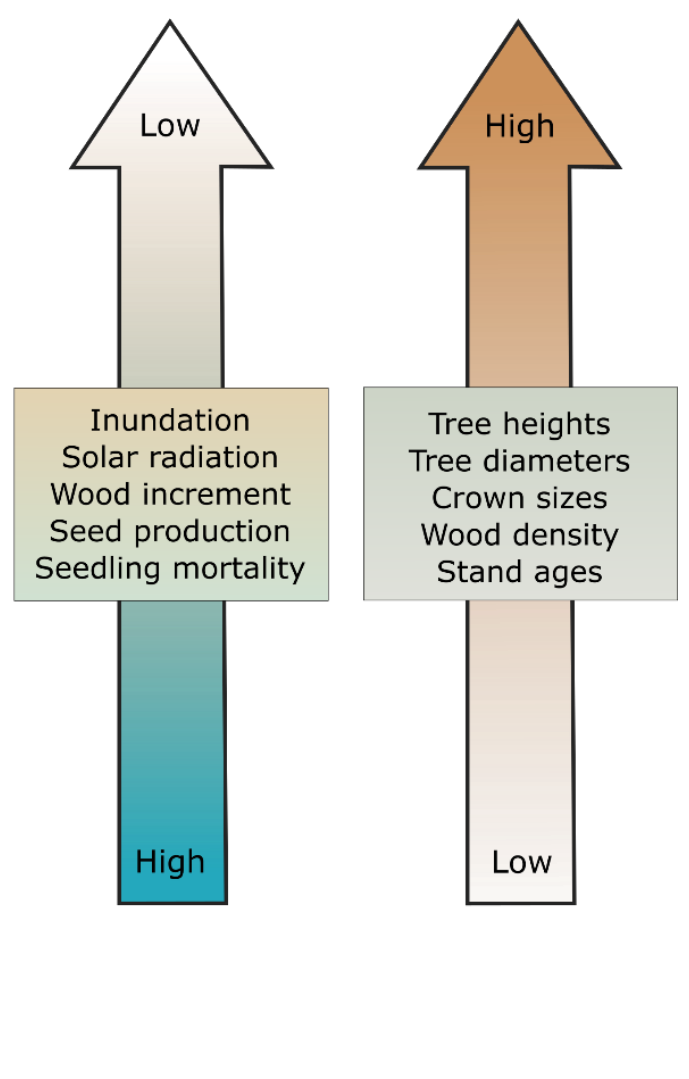

High sediment deposition

Figure 15 - Schematic types of forest succession in várzea floodplains. Simplified from Wittman et al. (2011). 


\subsubsection{2 lgapó}

Igapó (from tupi: $\mathrm{y}$ - water/river, apó - root) refers to the forests annually inundated by black or clearwater rivers. Buttress roots (Photo 9) and pneumatophores are common. The forest is often interspersed with sandy beaches and patches of open-vegetation, the campinaranas (Prance, 1979). Campinarana resembles savannah vegetation and grows over nutrient-poor white sandy soils, leached by blackwaters, which restricts the vegetation cover even under a climate suitable for forest development (Pires and Prance, 1985; Kubitzki, 1989). Trees have lower height and the canopy less stratified than várzea forest. Igapó forests are less diverse, e.g. Negro River inundated forest has about 63 species per ha, and is considered one of the poorest forest types in Amazonia (Montero and Latrubesse, 2013).

The most important families in igapó forests of Negro River are Fabaceae, Lecythidaceae, Chrysobalanaceae, Euphorbiaceae and Sapotaceae. Some common trees species are various members of the Myrtaceae family and the following genera of various plant families such as Triplaris, Piranhea, Coparifera, Alchornea, Escheweilera, Licania, Macrolobium, Pouteria, Virola, Laetia, Amanoa, Parkia, Crudia and Tabebuia. (Pires and Prance, 1985; Montero and Latrubesse, 2013; Montero et al., 2014).

According to Kalliola et al. (1991), herbaceous pioneer species are almost nonexistent in suspension-poor rivers of low erosion rate. Most of the bars remain poorly vegetated, suggesting that the site conditions are not favorable for the establishment of herbaceous vegetation.

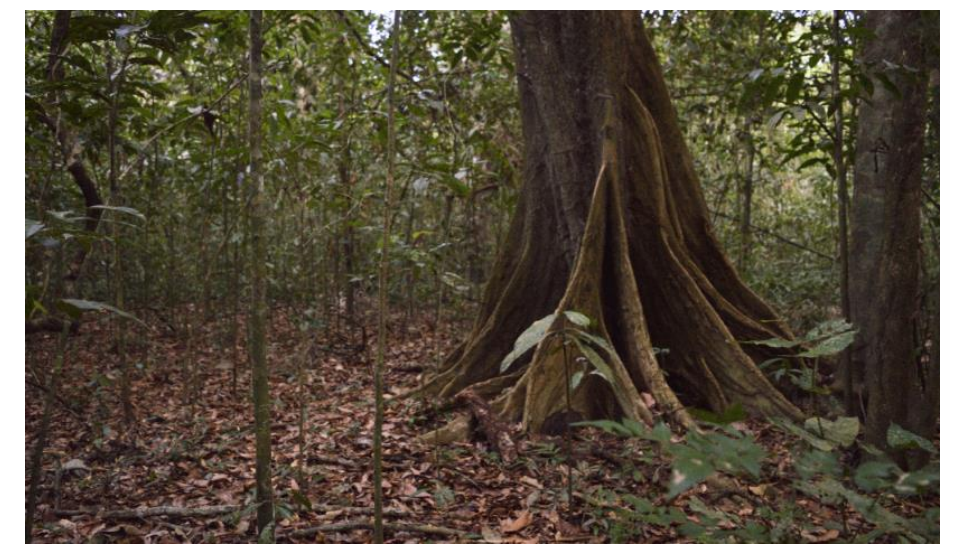

Photo 9 - Igapó forest understory at Xingu River floodplain. Trees buttressed by tabular roots are common in seasonal inundated forests. Photo: Thomas Akabane. 


\subsubsection{Floating meadows}

The floating meadows are extensive beds of floating emergent macrophytes that develop annually on the riverine margin of the floodplain, mostly formed by species of the Poaceae family, such as those in the Paspalum and Echinochloa genera. The grasses begin as terrestrial plants, develop aquatic growth forms as the water rises and decay as the waters fall during the dry season (Engle and Melack, 1989; Martinez and Le Toan, 2007). Clonal propagation is a very effective reproduction strategy of aquatic macrophytes, due to conditions that reduce or restricts the success of sexual reproduction. The increasing water depth prejudices the emergence of flowering structures, while benefits dispersion and growth of propagules, thus reducing the selective value of sexual reproduction, e.g., by reducing pollination success in self-incompatible species (Grace, 1993; Santamaría, 2002). Some of the most common semi-aquatic grasses present along the Amazon River accomplish specific parts of their life cycles during either the terrestrial or the aquatic phase. Because of these adaptations, they are abundant along the middle and lower Amazon River, where the floods are regular, and less common in the upper reaches due to unpredictable and rapid flood pulses (Junk and Piedade, 1993).

\subsection{Palynology}

A series of processes act over pollen and spores between its production, deposition and incorporation into the sedimentary record. The processes related to the production and release of pollen and spores are intrinsic to each plant and the depositional influences. The fluvial pollen load derive from local riverbank vegetation, surface run-off, regional wind and rain, and from reworked sediments of the floodplain (Haberle, 1997; Salgado-Labouriau, 2007). One pollen taxa cannot be used as a definitive indicator of any ecosystem; instead, associations of taxa are more adequate for this purpose (Colinvaux et al., 1999; Gosling et al., 2009). The absence of some pollen taxa in the record, despite the abundance of its correspondent plant in the landscape characterizes what is defined in Quaternary Palynology as "silent taxa" (Colinvaux et al., 1999). Some features that may result in a reduced representativeness of species in the pollen record are a low pollen production or dispersal capacity due to zoophilous strategy, closed flower structure, or investment in an asexual reproduction (Gosling et al., 2009). In fact, most of the vegetation 
is not expressed palynologically, for instance, pollen of large entomophilous trees are rare and under-represented in pollen rain (Bush, 1991; Gosling et al., 2005). Conversely, anemophillous taxa, which include Cecropia, Moraceae/Urticaceae, Alchornea are constantly over-represented in the record, even when absent from the local surrounding vegetation (Gosling et al., 2005; Burn et al., 2010). The sensitivy of the palynological method to detect changes of the adjacent forest structure reduces as the distance from the forest boundary increases (Whitney et al., 2018). Bush (1991) analyzed pollen from modern superficial sediments in lakes and concluded that is possible to discern major vegetation types, such as várzea, igapó, semi-deciduous, cerrado, and terra firme forest. Andean taxa in the lowlands are usually rare, with percentages lower than $3 \%$ (Haberle, 1997; Sá et al., 2016).

Through pollen traps, Gosling et al. (2009) observed that terra firme pollen rain of a moist evergreen tropical forest shows a dominance of Moraceae $(>40 \%)$ and an important contribution of Cecropia, Hyeronima, Celtis; a semi-deciduous dry tropical forest is characterized by Anadenanthera, Apuleia, Ferdinandusa, Asteraceae, Bromeliaceae, and Piper, whereas a cerradão exhibit the association of Poaceae, Myrtaceae, Borreria, Solanum, and Asteraceae. Poaceae correlates with open vegetated areas, though regions of cerrado can present low grass pollen production whereas in some floodplain lakes it can be fairly abundant (Gosling et al., 2009; Horbe et al., 2011; Sá et al., 2016). Melastomataceae/Combretaceae, Pouteria, Sapium, and Symmeria are well represented in seasonally inundated and riparian forests (Burn et al., 2010). Pollen of Cecropia is abundant in meandering rivers sediments, where fluvial dynamics constantly disturbs the environment and promote succession of the riparian vegetation (Burn et al., 2010; Rodríguez-Zorro et al., 2015).

From a core in a floodplain lake of Solimões River, Sá et al. (2016) interpret an advancing vegetative succession as the water level decreases. The first stages are represented by Alchornea, Cecropia, Symmeria and pioneer herbs (Poaceae, Asteraceae, Alternanthera) and as the succession progresses, pioneer taxa give place to Pseudobombax, Luehea, Laetia, Ryanaea, among others. Taxa adapted to fine substrate and calmer environments, such as Symmeria and Myrtaceae, decrease with increasing sedimentation. 
In southern Peru, Weng et al. (2004) studied the pollen rain of a elevational transect along Madre de Dios and Manu rivers through moss-pollsters and surface sediments. The palynological assemblage of lowland back-swamps are characterized by abundant Mauritia and Sloanea, and in new oxbows or disturbed habitats Cecropia is the dominant taxa. Pollen from Iriartea, Ficus, Urticaceae/Moraceae, Acalypha and Alchornea are constantly present in these areas. At higher elevations, these types decrease or are absent. At medium and mid-high elevations (1000-2000 m), Cecropia is dominant and Acalypha, Melastomataceae/Combretaceae, Hedyosmum, and Poaceae are abundant. Alnus begins to increase at high elevations and dominates the upper Andean forest (2000$2700 \mathrm{~m}$ ). At the high Andean open vegetation (>2700 m), Asteraceae and Poaceae are the dominant pollen taxa, with occurrence of Alnus, Myrsine, Myrica, Polylepis, and Ericaceae.

\subsubsection{Waterborne pollen}

The fluvial system is very efficient in transporting pollen grains throughout long distances, from the headwaters to the river mouth (Muller, 1959; Haberle, 1997; Zhu, 2003). The pollen load transported by rivers are nearly uniform and preferentially deposited within the fine sediments (Brush and Brush, 1972; Smirnov et al., 1996; Brown et al., 2007). Differential deposition of grains by hydrodynamics of transport is recognized by some authors (Muller, 1959; Brush and Brush, 1972; Catto, 1985), while according to others, it is minimal or unlikely to affect the deposited assemblages along the river channel (Smirnov et al., 1996; Moss et al., 2005). A seasonal variability related to blooming and flooding periods are known to control composition and concentration of the waterborne pollen in temperate basins (Chmura and Liu, 1990; Smirnov et al., 1996; Brown et al., 2007), which in some extend may also apply to tropical basins. The waterborne load is influenced by discharge and increases during the flood season, probably due to flushing out of pollen and sediments accumulated within the channel system (Brown, 1985; Brown et al., 2007).

\section{MATERIALS AND METHODS}


River bed sediments were collected in expeditions linked to FAPESP projects Proc. 11/06609-1, 12/50260-6 and 16/02656-9 along the Içá, Japurá, Juruá, Tefé, Coari, Purus, Solimões Amazonas, Negro, Madeira, Tapajós, Xingu and Pará rivers during the dry seasons of 2011 and 2015 and the wet season of 2012 (Figure 16). As the Amazon River enters the Brazilian territory it is known as the Solimões River until the Negro River confluence, near Manaus. There, downstream from Negro River it is called Amazonas River. The Brazilian geographical names are adopted for each stretch - Solimões and Amazonas -, and when referred to the river system as a whole, the name Amazon River is used.

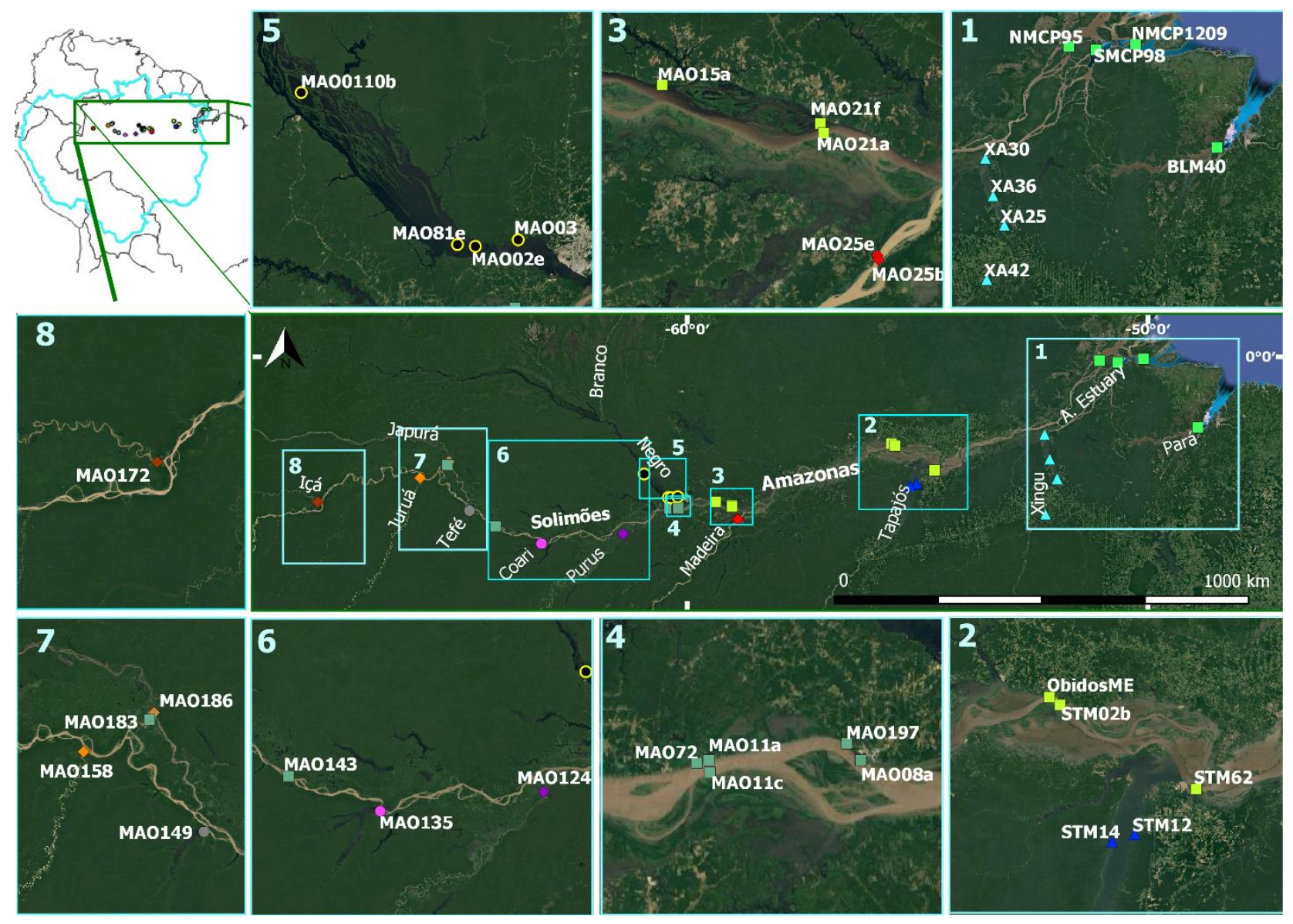

Figure 16 - Sampling sites over the studied area.

Sampling was made on the fluvial channels with a Van Veen bottom sampler (Photo 10 ) with the superficial sediments then stored in sealed plastic bags. Samples intended 
for palynological analysis were preferentially selected based on grain size and organic content. When no finer sediments were available, coarser ones were chosen in order to achieve a geographical representativeness and adequate spacing between samples. Selected samples were subsampled in the Micropaleontology Laboratory of the Institute of Geosciences of the University of São Paulo (IGc/USP) for palynology, grain size and xray fluorescence (XRF) analyses.

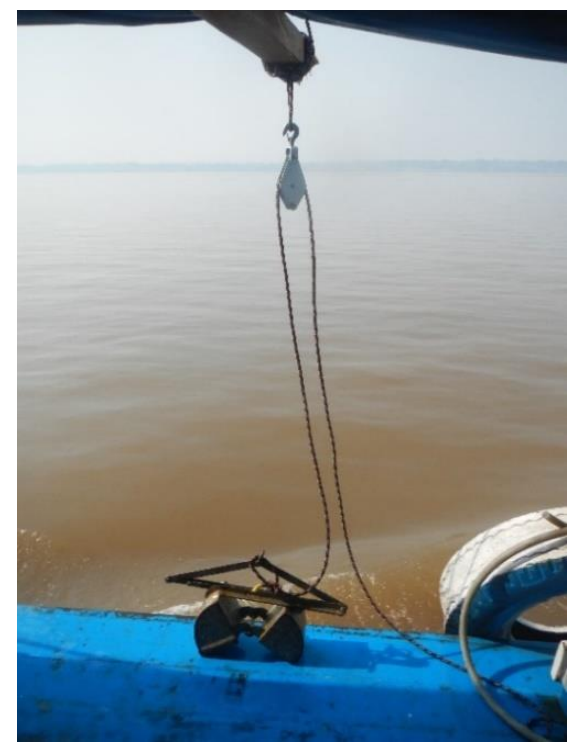

Photo 10 - Van Veen sampler. Photo: André Stern.

Palynological analysis were carried out on 36 sediment subsamples of $1 \mathrm{~cm}^{3}$ each, covering an area that extends from the Içá River to the Amazon Estuary (Table 1). Pollen extraction of all samples followed standard methods employing hydrofluoric acid and acetolysis composed of 9 parts acetic anhydride and 1 part sulfuric acid (Faegri and Iversen, 1966; Erdtman, 1986; Colinvaux et al., 1999). Pollen concentrations (grains/ $/ \mathrm{cm}^{3}$ ) in the sediments were calculated based on the addition of one Lycopodium clavatum tablet to each sample before the extraction (Stockmarr, 1971). Residues were stored in glycerine and mounted in semi-permanent slides sealed with parafin, counted at 400X and 1000X (oil) magnifications in a Zeiss Axio Scope A1 and Zeiss Axio Lab.A1 compound light microscopes. An intended minimum of 300 pollen grains was counted in most of the samples, whenever possible; damaged grains (corroded, folded and broken), pteridophyta and fungi spores were counted apart. Taxa that corresponds to more than about a third of the assemblage $(>30 \%)$ is considered overrepresented and counted apart. Identification 
was based on morphological descriptions and illustrations present in Hooghiemstra (1984), Roubik and Moreno (1991), Colinvaux et al. (1999), Lorente et al. (2017) and on the modern pollen reference collection of the Micropaleontology Laboratory of IGc/USP, containing over 6,000 neotropical plant species. Paleontological Statistics Software (PAST) was used to process data for multivariate analyses (DCA) and to create pollen graphs by locally estimated scatterplot smoothing (LOESS) and histograms (Hammer et al., 2001). The average 'unidentified grains' category accounts for about $10 \%$ of the total assemblages. Detrended Correspondence Analysis (DCA) is a specialized module for ecological data set analysis, and it has become a standard method for studying gradients in such data. DCA provides an interpretable species ordination in Standard Deviation of Species Turnover (SD units) (Hill and Gauch, 1980).

Grain size analysis was conducted on Mastersizer 2000 laser diffraction particle size analyser (Malvern Instruments), except on samples from the Amazon Estuary that were already grounded before subsampling. For X-ray fluorescence spectrometry analysis (XRF), on PANalytical Epsilon3-XL XRF with emphasis on $\mathrm{Ca}, \mathrm{Fe}, \mathrm{Si}, \mathrm{Ti}, \mathrm{K}, \mathrm{P}$, $\mathrm{Al}$, subsamples of bulk material were grounded in agate mortar, homogenized and dried. 
Table 1 - Sample code, river, position, depth of sampling, season, sediment class (Folk, 1974) according to grain size, grain size index $\mathrm{Al} / \mathrm{Si}$, pollen count, pollen concentration, and other palynological aspects.

\begin{tabular}{|c|c|c|c|c|c|c|c|c|c|c|c|c|c|c|c|c|c|c|}
\hline Sample & River & Long & Lat & Depth $(\mathrm{m})$ & Season & Sed. Class & $\mathrm{Al} / \mathrm{Si}$ & P. Count & P. Conc. & Trees & Cecr. & Herbs & Poac. & Palms & Lianas & Spores & Unk. & Dmg \\
\hline MAO172 & Içá & -68.018 & -3.15 & 8.5 & Dry & sandy silt & 0.189 & 77 & 4826 & $31 \%$ & $26 \%$ & $8 \%$ & $1 \%$ & $3 \%$ & $3 \%$ & $12 \%$ & $7 \%$ & $9 \%$ \\
\hline MAO186 & Japurá & -65.168 & -2.279 & 2 & Dry & silty sand & 0.118 & 278 & 6417 & $21 \%$ & $23 \%$ & $19 \%$ & $1 \%$ & $6 \%$ & $1 \%$ & $9 \%$ & $9 \%$ & $11 \%$ \\
\hline MAO183 & Solimões & 5.211 & -2.343 & 17 & Dry & silty sand & 0.122 & 58 & 1148 & $28 \%$ & $22 \%$ & $8 \%$ & $4 \%$ & $8 \%$ & $4 \%$ & $12 \%$ & $3 \%$ & $12 \%$ \\
\hline MAO158 & Juruá & -65.797 & -2.628 & 7.5 & Dry & sandy silt & 0.143 & 736 & 11917 & $21 \%$ & $33 \%$ & $4 \%$ & $3 \%$ & $3 \%$ & $1 \%$ & $10 \%$ & $9 \%$ & $16 \%$ \\
\hline MAO149 & Tefé & -64.724 & -3.34 & 2.2 & Dry & mud & 0.325 & 361 & 38532 & $57 \%$ & $17 \%$ & $4 \%$ & $3 \%$ & $1 \%$ & $1 \%$ & & $9 \%$ & $5 \%$ \\
\hline MAO135 & Coari & & -4.053 & 3 & Dry & & 0.219 & & 66275 & $29 \%$ & $28 \%$ & $10 \%$ & $8 \%$ & $1 \%$ & $1 \%$ & $3 \%$ & $7 \%$ & $13 \%$ \\
\hline MAO124 & & -61.393 & -3.843 & 26 & Dry & silt & 0.184 & & & $24 \%$ & $39 \%$ & & $6 \%$ & $1 \%$ & & $4 \%$ & $10 \%$ & $8 \%$ \\
\hline MAO143 & Solimões & -64.156 & -3.676 & 18 & Dry & silty sand & 0.134 & 193 & 2450 & $17 \%$ & $20 \%$ & $6 \%$ & $9 \%$ & $6 \%$ & $2 \%$ & $12 \%$ & $10 \%$ & $19 \%$ \\
\hline MAO72 & Solimões & -60.4 & -3.291 & 28 & Wet & sandy silt & 0.180 & 537 & 20755 & $25 \%$ & $24 \%$ & $7 \%$ & $8 \%$ & $4 \%$ & $1 \%$ & $16 \%$ & $4 \%$ & $12 \%$ \\
\hline MAO11c & Solimões & -60.384 & -3.302 & 3.5 & Dry & sandy silt & 0.191 & 549 & 23833 & $20 \%$ & $27 \%$ & $7 \%$ & $4 \%$ & $7 \%$ & $1 \%$ & $10 \%$ & $14 \%$ & $9 \%$ \\
\hline MAO11a & Solimões & -60.385 & -3.287 & 21 & Dry & sandy silt & 0.206 & 306 & 8291 & $34 \%$ & $25 \%$ & $14 \%$ & $6 \%$ & $1 \%$ & & $5 \%$ & $3 \%$ & $12 \%$ \\
\hline & Solimões & -60.216 & -3.267 & 1 & Dry & & 0.175 & 655 & 20871 & $14 \%$ & $44 \%$ & $6 \%$ & $9 \%$ & $2 \%$ & $1 \%$ & $8 \%$ & $9 \%$ & $8 \%$ \\
\hline & & & & 16 & & & & & 9225 & $19 \%$ & $15 \%$ & & & $3 \%$ & & & $23 \%$ & $15 \%$ \\
\hline MAO15a & Amazonas & & -3.147 & & Dry & sandy silt & 0.182 & 148 & & $19 \%$ & $20 \%$ & $7 \%$ & $5 \%$ & $5 \%$ & & & $9 \%$ & $17 \%$ \\
\hline MAO15e & Amazonas & & & & Dry & silty sand & 0.153 & 191 & 1631 & $22 \%$ & $19 \%$ & $8 \%$ & $6 \%$ & $3 \%$ & & $14 \%$ & $8 \%$ & $20 \%$ \\
\hline $\mathrm{MAO} 21 \mathrm{f}$ & Amazonas & -59.034 & -3.232 & & Dry & sandy silt & 0.197 & 361 & 12140 & $26 \%$ & $12 \%$ & $9 \%$ & $14 \%$ & $3 \%$ & $2 \%$ & $11 \%$ & $13 \%$ & $10 \%$ \\
\hline MAO21a & Amazonas & -59.027 & -3.254 & & Dry & sandy silt & 0.184 & 326 & 9011 & $19 \%$ & $19 \%$ & $7 \%$ & $10 \%$ & $5 \%$ & $1 \%$ & $20 \%$ & $8 \%$ & $11 \%$ \\
\hline ObidosME & Amazonas & -55.564 & -1.885 & 1 & Dry & & 0.168 & 132 & 6050 & $17 \%$ & $13 \%$ & $15 \%$ & $10 \%$ & $5 \%$ & $2 \%$ & & $7 \%$ & $17 \%$ \\
\hline STM02b & & & -1.935 & & Wet & & 0.190 & & & $18 \%$ & $19 \%$ & & $18 \%$ & $3 \%$ & & & $12 \%$ & $16 \%$ \\
\hline STM62 & Amazonas & -54.631 & -2.466 & & & & 0.217 & & & $18 \%$ & $14 \%$ & $13 \%$ & $13 \%$ & $6 \%$ & & & $3 \%$ & $15 \%$ \\
\hline & A. Estuary & & -0.082 & & Wet & & & & & $21 \%$ & $8 \%$ & & & $3 \%$ & & & $9 \%$ & $26 \%$ \\
\hline SMCP98 & A. Estuary & -50.657 & -0.1284 & 2 & Wet & & & & & $8 \%$ & $9 \%$ & & $9 \%$ & $2 \%$ & 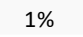 & & $13 \%$ & $29 \%$ \\
\hline NMCP1209 & A. Estuary & -50.091 & -0.051 & 3 & Wet & & & & & $16 \%$ & $9 \%$ & & $6 \%$ & $4 \%$ & & & $7 \%$ & $29 \%$ \\
\hline BLM40 & Pará & -48.919 & -1.533 & 40 & Wet & & 0.186 & 600 & & $19 \%$ & $17 \%$ & $10 \%$ & $17 \%$ & $1 \%$ & 10 & & $14 \%$ & $18 \%$ \\
\hline MAO0110b & Negro & -60.935 & -2.545 & & & & 0.422 & & & $60 \%$ & $13 \%$ & & & $1 \%$ & 10 & & $6 \%$ & $5 \%$ \\
\hline MAO81e & Negro & -60.41 & -3.055 & & Wet & & 0.162 & & & $30 \%$ & $6 \%$ & $4 \%$ & $18 \%$ & $4 \%$ & $2 \%$ & $4 \%$ & $18 \%$ & $15 \%$ \\
\hline $\mathrm{MAO02 \textrm {e }}$ & Negro & -60.35 & -3.061 & 16 & Dry & & 0.292 & 75 & & $48 \%$ & $5 \%$ & $9 \%$ & $11 \%$ & $2 \%$ & $1 \%$ & $6 \%$ & $7 \%$ & $11 \%$ \\
\hline MAO03 & Negro & -60.206 & -3.039 & 0.7 & Dry & & 0.300 & 839 & & $32 \%$ & $9 \%$ & $4 \%$ & $26 \%$ & $2 \%$ & $2 \%$ & $2 \%$ & $7 \%$ & $15 \%$ \\
\hline MAO25e & Madeira & -58.908 & & 10 & & & 0.181 & & & $16 \%$ & $8 \%$ & $6 \%$ & $1 \%$ & $8 \%$ & $1 \%$ & & $8 \%$ & $12 \%$ \\
\hline $\mathrm{MAO} 25 \mathrm{~b}$ & & & & 22 & & & & & & & $14 \%$ & & & $3 \%$ & & & $10 \%$ & $29 \%$ \\
\hline STM12 & Tapajós & -55.022 & -2.752 & & Wet & silty sand & 0.034 & & & $20 \%$ & $7 \%$ & $19 \%$ & $39 \%$ & $1 \%$ & & & $8 \%$ & $5 \%$ \\
\hline STM14 & Tapajós & -55.166 & -2.798 & & Wet & silty sand & 0.094 & 135 & 2176 & $22 \%$ & $6 \%$ & $17 \%$ & $20 \%$ & $1 \%$ & $1 \%$ & $5 \%$ & $5 \%$ & $24 \%$ \\
\hline XA42 & Xingu & -52.222 & -3.419 & & Wet & sandy silt & 0.168 & 646 & 19821 & $36 \%$ & $31 \%$ & $5 \%$ & $1 \%$ & $3 \%$ & $1 \%$ & $2 \%$ & $7 \%$ & $15 \%$ \\
\hline XA25 & Xingu & -51.97 & -2.645 & 2.3 & Dry & sandy silt & 0.284 & 598 & 51089 & $29 \%$ & $47 \%$ & $3 \%$ & $3 \%$ & $2 \%$ & $1 \%$ & $4 \%$ & $4 \%$ & $6 \%$ \\
\hline XA36 & Xingu & -52.132 & -2.222 & 9.2 & Dry & & 0.332 & 767 & 18203 & $29 \%$ & $31 \%$ & $6 \%$ & $3 \%$ & $3 \%$ & $2 \%$ & $5 \%$ & $8 \%$ & $14 \%$ \\
\hline XA30 & Xingu-confl & -52.243 & -1.688 & 13 & Dry & sandy silt & 0.217 & 220 & 34438 & $14 \%$ & $26 \%$ & $8 \%$ & $15 \%$ & $2 \%$ & $1 \%$ & $8 \%$ & $10 \%$ & $17 \%$ \\
\hline
\end{tabular}

\section{RESULTS}

\subsection{Sedimentary and Geochemical aspects}

The analyzed sediments containing pollen vary from silt to silty sand after Folk's classification (1974) (Figure 17). According to Pejrup (1988), the sand content is not always a good indicator of the depositional environment because sand can be transported both in suspension and along the bottom, and also because the sand class covers a wide range of grain sizes. Furthermore, the sand content of a sediment may be very dependent on the distance from the source. For instance, pollen is present in coarse sediments from Tapajós ria due to calmer hydrodynamic conditions that favor its deposition, as these 
sands are derived from the erosion of banks and do not represent high-energy environments (Sioli, 1984).

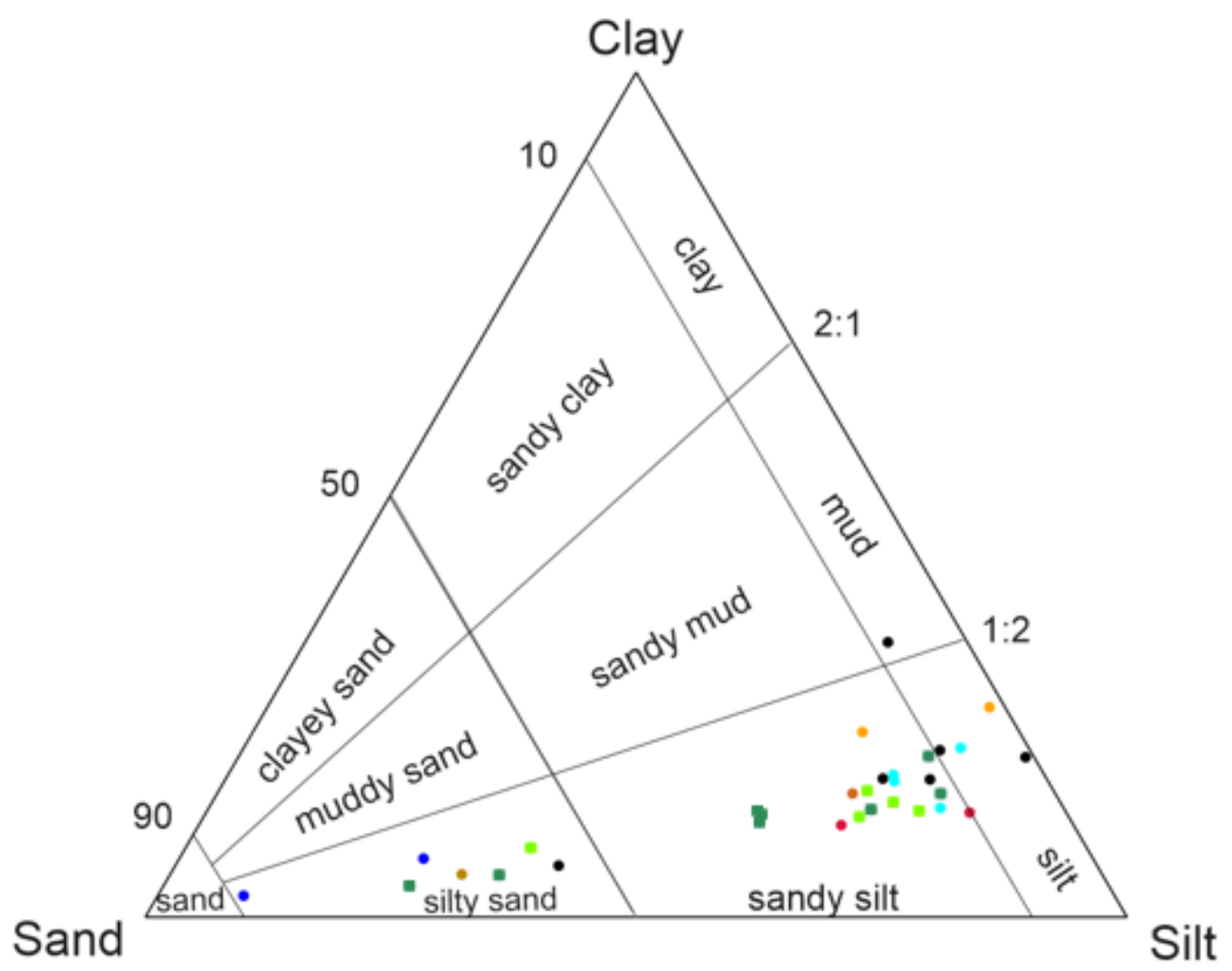

Figure 17 - Ternary diagrams based on sand/silt/clay ratios measured in Malvern. A: Diagram for the textural classification of sediments (Folk, 1974). Solimões (darkgreen), Amazonas (lightgreen), Negro (black), Xingu (cyano), Madeira (red), Tapajós (blue), Coari (purple), Tefé (gray), Purus (pink), Juruá (orange), Japurá (dark brown), Içá (light brown).

As demonstrated by Bouchez et al. (2011), the Al/Si ratio tighly correlates with grain size, this negative correlation is also observed in the analyzed samples and henceforth is used as a grain size index (Figure 18). Xingu, Negro, and Tefé Rivers sediments are comparatively enriched in Al for the same grain size of whitewater riverbed sediments. 


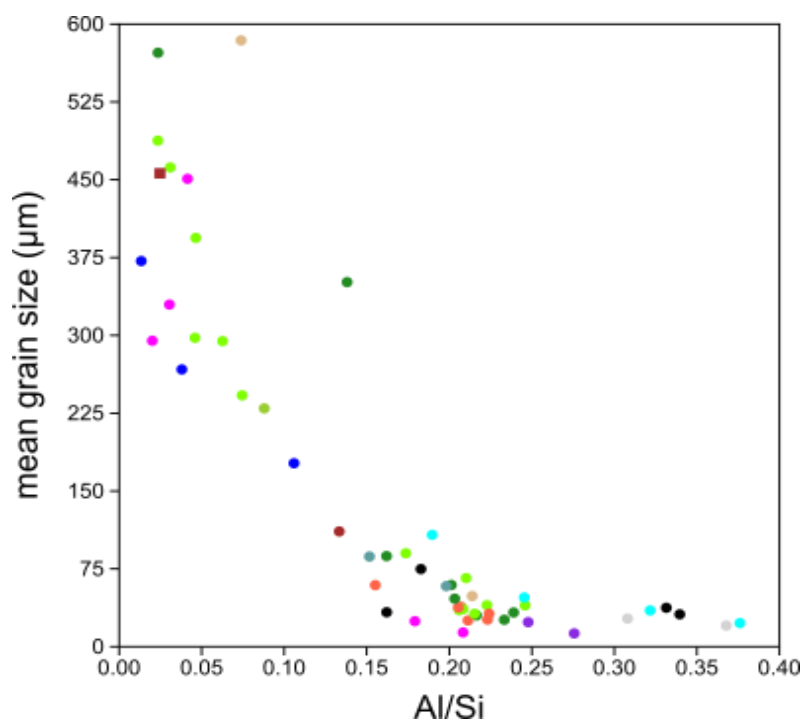

Figure 18 - Correlation of mean grain size measured on Malvern and Al/Si ratio, a grain size index, of all riverbed sediments. Solimões (darkgreen), Amazonas (lightgreen), Negro (black), Xingu (cyano), Madeira (red), Tapajós (blue), Coari (purple), Tefé (gray), Purus (pink), Juruá (orange), Japurá (dark brown), Içá (light brown).

Inorganic sediments can be used as good indicators of the source area, weathering intensity, and maturity; inasmuch as minerals are directly related to their parent-rocks and chemical elements behave according to different environmental conditions. Sediments from lowland tributaries are more weathered and mature than sediments brought by montane regions. Predominance of physical weathering in Andean mountainous environment favors formation of illite $\left(\mathrm{KAl}_{2}(\mathrm{OH})_{2}\left[\mathrm{AlSi}_{3}(\mathrm{O}, \mathrm{OH})_{10}\right]\right)$ as byproduct, while chemical weathering in the lowlands, under tropical and humid conditions, induces the formation of kaolinite $\left(\mathrm{Al}_{2} \mathrm{O}_{3} .2 \mathrm{SiO}: .2 \mathrm{H}: \mathrm{O}\right)$ (Guyot et al., 2007). Intense and long-term weathering also favors the enrichment of $\mathrm{Ti}$ in sediments as residues or as neoformed anatase, a mineral form of titanium dioxide (Cornu et al., 1999). Therefore, those rivers that carry sediments from the highlands have high $\mathrm{K}$ and $\mathrm{Ca}$ contents. On the other hand, rivers that gather sediments from the lowland basins are enriched in $\mathrm{Al}, \mathrm{Ti}$ and $\mathrm{Fe}$. Blackwater rivers exhibit enriched Ti sediments, whereas clearwater rivers born at the cratonic domains are $\mathrm{Fe}$ rich, hence $\mathrm{Fe} / \mathrm{Ti}$ ratio works as a good proxy differentiating these river types (Figure 19.C). Pará River is differentiated from the Amazon River samples by higher $\mathrm{Al} / \mathrm{K}$ ratio and Fe content, and exhibits an intermediate composition between clear and whitewater rivers. 
Sediments from whitewater river are separated from clear and blackwater rivers based on the $\mathrm{Al} / \mathrm{K}$ ratio (Figure 19Figure 20 ), an index for mineralogical maturity. $\mathrm{Al}$ and $\mathrm{K}$ are associated with fine-grained particles and are grain-size dependent (Govin et al., 2014). Madeira River sediments distinguishes from those of Solimões and Amazonas Rivers by relative depleted Ca content shown by the Fe/Ca ratio (Figure 19.A). Recent várzea sediments are relatively rich in Ca compared to Andean sediments (Irion et al., 2010), which might indicate that Amazon River load have a bigger contribution from reworked sediments of várzea compared to the Madeira River.

Samples of Coari-lake (MAO135) and lower Xingu ria (XA30) exhibit geochemical characteristics of Solimões and Amazonas riverbed sediments, evidencing a predominant deposition from the mainstem channel (Figure 19Figure 20). As already observed by Häggi et al. (2016), upstream samples from Xingu River show elevated Fe/K ratios, expected for the material originated from the heavily weathered Central Brazil Shield rocks, while the sample from the lower Xingu ria, near the confluence, shows a lower Fe/K ratio (Figure 19.B). This index, however, does not differentiate sediments of Negro and Tefé from those of whitewater rivers.

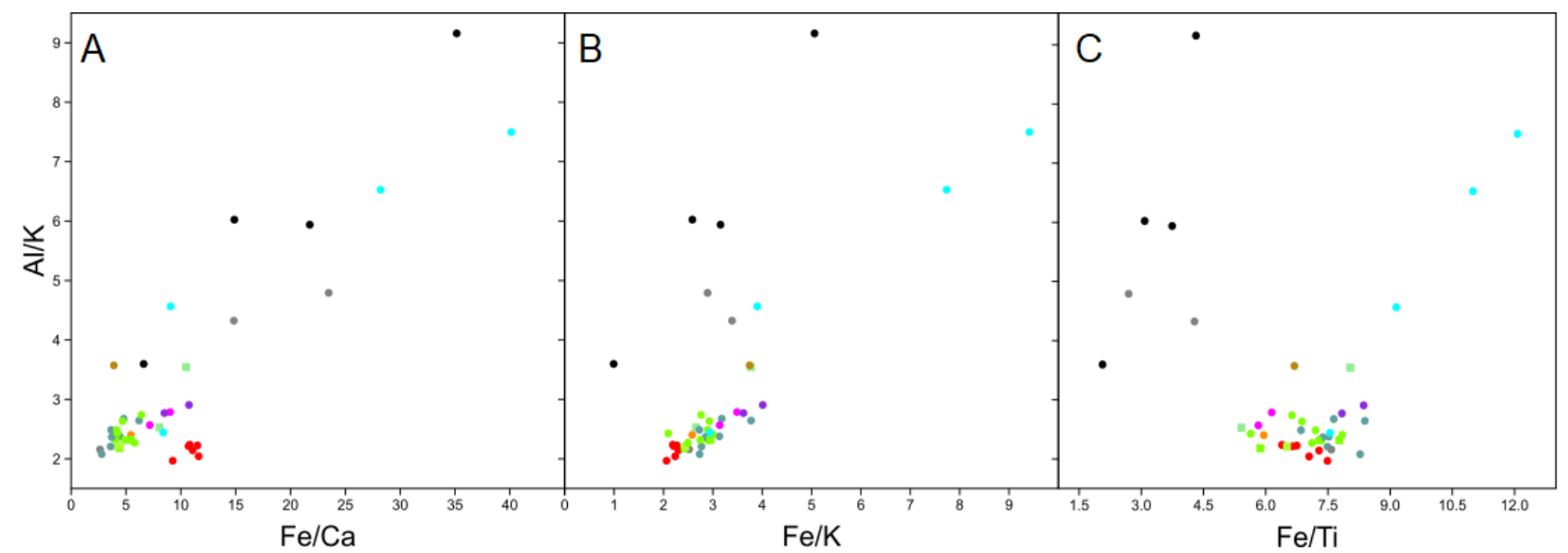

Figure 19 - Geochemistry of riverbed sediments from rivers: Solimões (darkgreen), Amazonas (lightgreen), Amazon estuary (lightgreen squares), Negro (black), Xingu (cyano), Madeira (red), Coari (purple), Tefé (gray), Purus (pink), Juruá (orange), Içá (brown). The graphs show a clustering of whiteriver samples, which also include those from Coari and the Xingu-Amazonas confluence, and scattering of samples from Negro, Tefé and Xingu, indicating higher weathered sediments. 


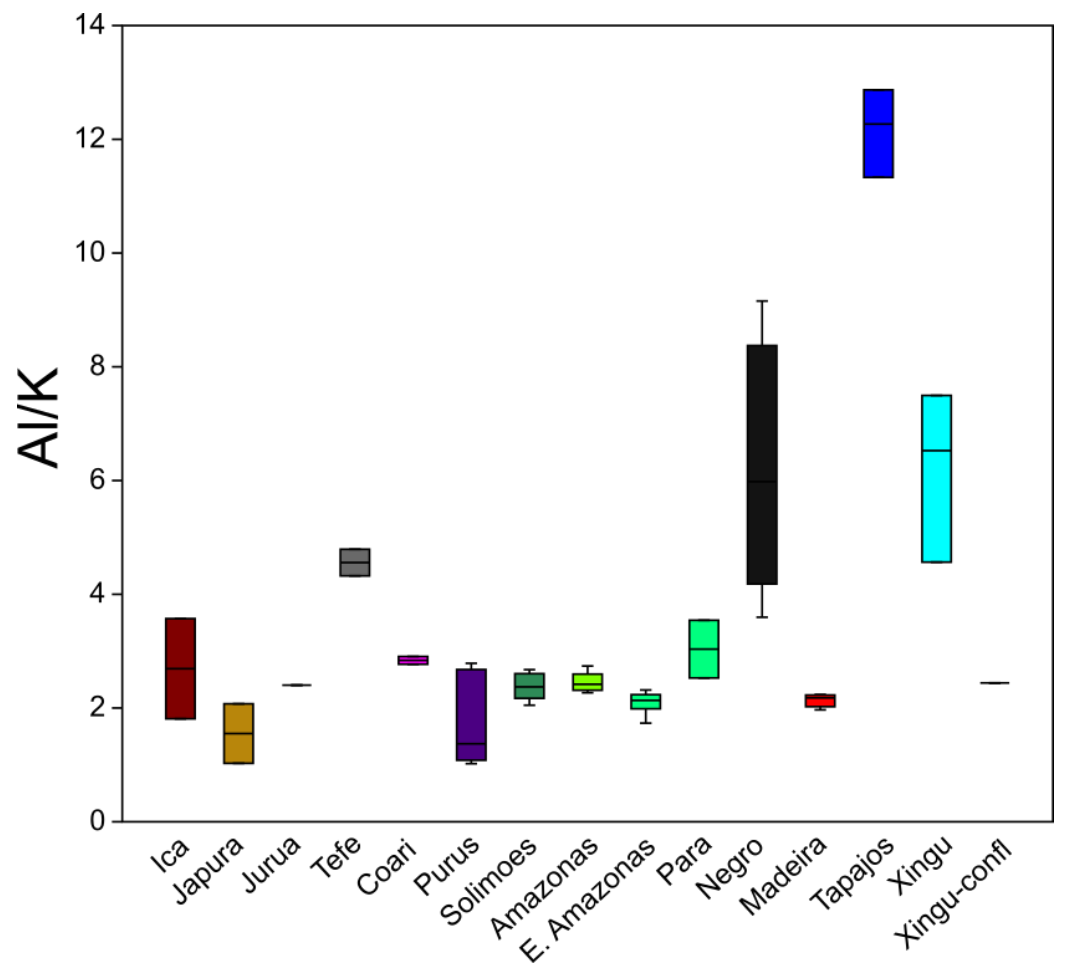

Figure 20 - Boxplot of $\mathrm{Al} / \mathrm{K}$ ratio shows that Coari and Xingu confluence samples have contribution of less mature sediments, typical of Solimões-Amazonas. Samples containing coarser sediments such as Içá, Japurá, and Tapajós might be influenced by the grain size.

\subsection{General Aspects of Surface Pollen Signatures}

\subsubsection{Pollen Concentration}

Pollen is fairly abundant in most fine grained samples and its concentration covers an order of magnitude from 1,500 to 68,000 pollen grains $/ \mathrm{cm}^{3}$ of sediment (PGS). Sediment samples with coarser grain size tend to exhibit lower pollen concentrations, though this relation is not straightforward (Figure 21.A). Pollen grains have a very low specific gravity of $\sim 0.5-1.2$ and settling speed of $\sim 4-7 \mathrm{~cm} /$ hour, thus behave roughly like fine silt particles during transport (Durham, 1947; Muller, 1959). The average amount of pollen grains contained in $1 \mathrm{~cm}^{3}$ of sediment in whitewater rivers is about $\sim 10,500$, whereas in clearwater rivers $\sim 31,000$, and in blackwater rivers $\sim 47,000$ (Figure 21.B). Pollen concentration relates to the sedimentation rate since its value is calculated after a given volume of sediment; therefore, the palynological content becomes diluted in rivers with a higher amount of suspended sediments, yielding lower concentrations. Higher 
concentrations in black and clearwater rivers are attributed to low sedimentation rates in calmer lake-like environment that favor the accumulation of pollen and organic matter.

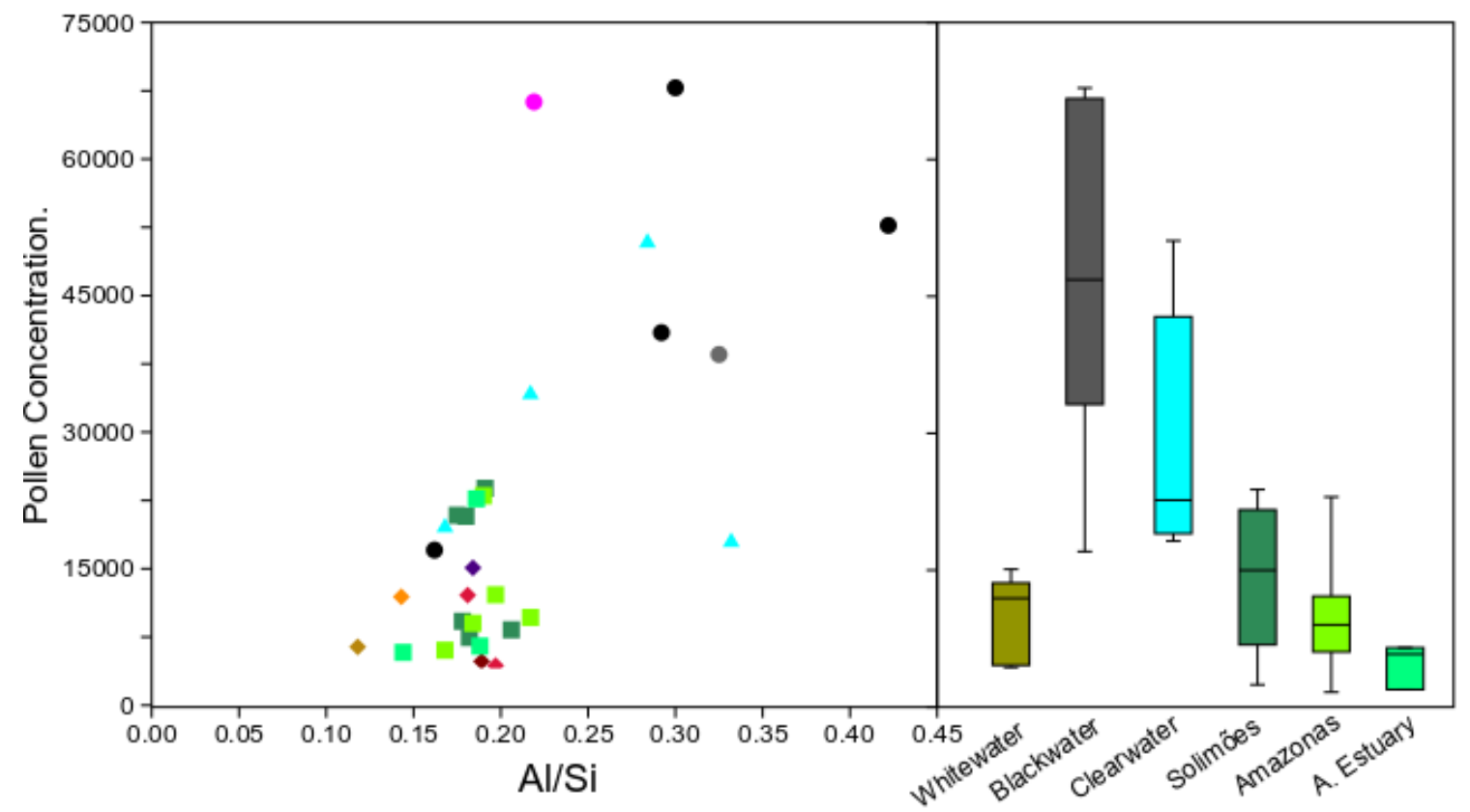

Figure 21 - A: Correlation of pollen concentrations and grain size proxy, Al/Si ratio. B: Boxplot of pollen concentration grouped according to water type; sediments coarser than sandy silt were removed. Whitewater group includes sediments from Madeira, Japurá, Purus, Juruá and Içá; Blackwater group includes sediments from Negro, Tefé; Clearwater group is restricted to Xingu.

The particulate organic carbon carried by rivers is dependent on the physical processes governing sediment dynamics and microbial degradation (Moreira-turcq et al., 2003). Total organic carbon (TOC) content data previously published by Häggi et al. (2016) and Sun et al. (2017) for some of the present analyzed riverbed samples are compared with pollen concentration values (Figure 22). Negro and Xingu rivers present higher TOC and pollen concentrations than Solimões and Amazonas rivers, whereas Madeira River exhibits the lowest values. Although it is not tightly correlated, both follow the same pattern, which is expected as the variables are influenced by the suspended load, sediment grain size and are preserved under similar conditions (Moreira-turcq et al., 2003; Sun et al., 2017). 


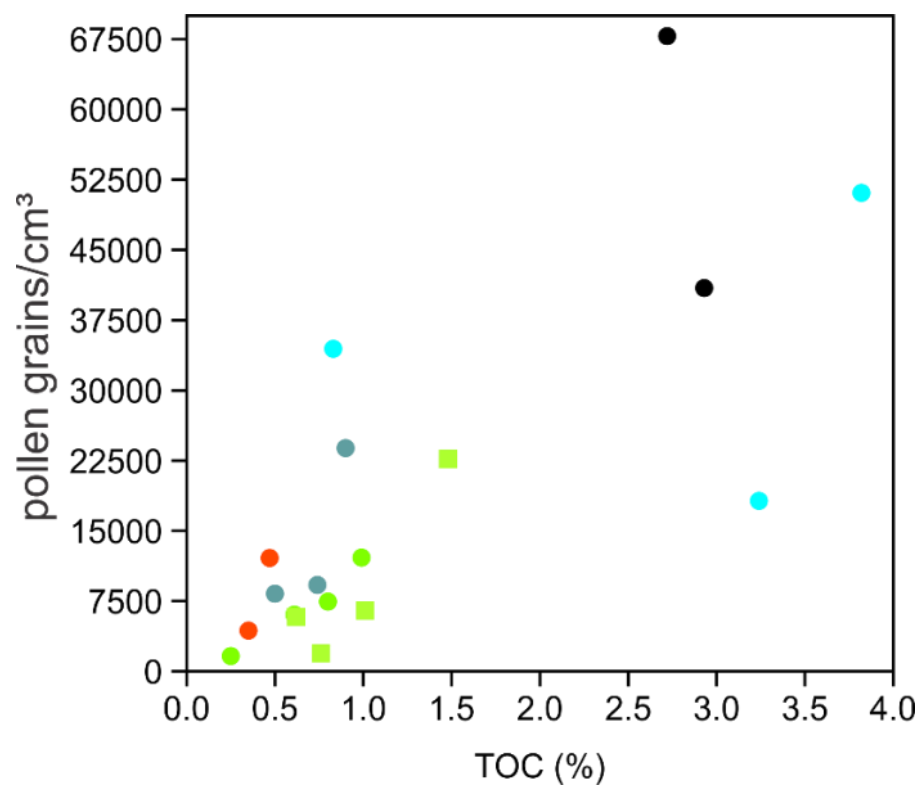

Figure 22 - Pollen concentration (pollen grains $/ \mathrm{cm}^{3}$ ) (this study) and TOC (\%) presented by Sun et al. (2017). Solimões River (cadetblue), Amazonas River (green dots), Amazon Estuary (green squares), Madeira River (red), Negro River (black), Xingu River (cyano).

\subsubsection{Pollen aspects}

The modern palynological signatures of the Brazilian amazonian rivers are characterized by a ubiquitous presence of Cecropia, Poaceae, Alchornea, Melastomataceae/Combretaceae, Moraceae, Symmeria and Asteraceae, additionally to an important contribution of Cyperaceae, Myrtaceae and Iriartea. Most of the identified taxa belong to families/genera found both in floodplain and terra firme, or exclusively in inundated forests, whereas those restrict to terra firme contributes with low percentages and usually exhibit sporadic occurrences $<3 \%$.

The complete list of pollen types belonging to 74 families and the respective ecological settings is shown on Appendix 1 and the pollen plates in Appendix 2. The ecological distribution in terra firme, várzea, montane forests, savannah and cerrado, was based on floristic survey works (Prance, 1979; Campbell et al., 1986; Kalliola et al., 1991; Rankin-de-Mérona et al., 1992; Junk and Piedade, 1993; Wittmann et al., 2002, 2006; Marchant et al., 2002; Miranda et al., 2003; Duque et al., 2003; Gama et al., 2003, 2005; Carneiro, 2004; Ortuño and Borsch, 2006; Toledo and Salick, 2006; Helena et al., 2008; Scudeller and Souza, 2009; Marchioretto et al., 2010; Sousa, 2012; Silva e Silva et al., 
2013; Carim, 2016; Maciel et al., 2016; Lombardi and Biral, 2016; Silva et al., 2016; Scudeller and Vegas-Vilarrúbia, 2018).

\subsubsection{Pollen degradation}

Pollen degradation has a light increasing tendency downstream the Amazon River system and negatively correlates to absolute values of pollen concentration, which might reflect a series of factors (Figure 23).

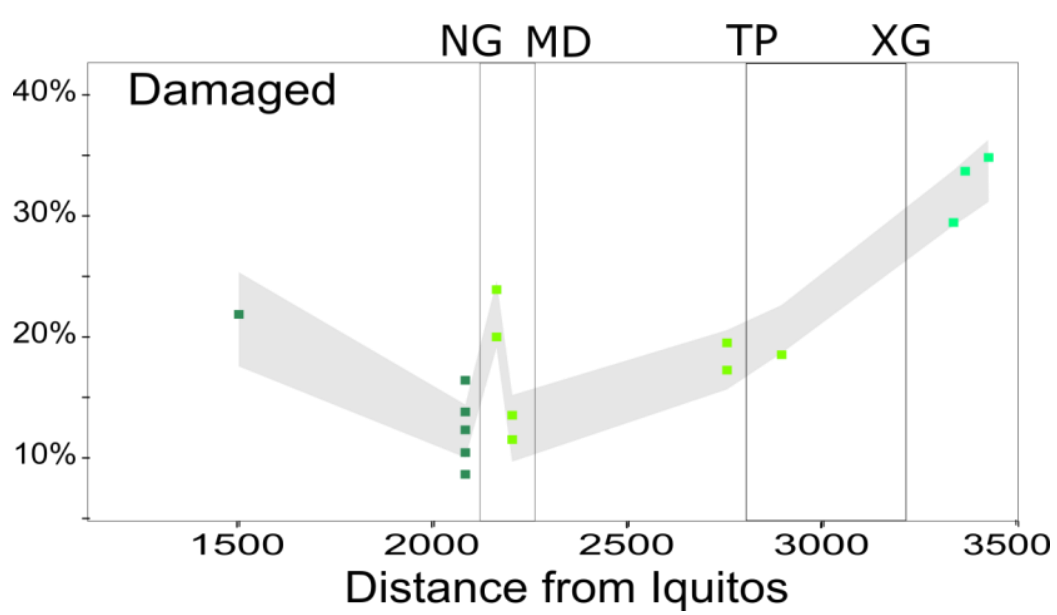

Figure 23 - LOESS: Damaged grains through the Amazon River by distance from lquitos. Dark green squares: Solimões River; Light green squares: Amazon River; Grey band: 95\% confidence band calculated by LOESS, with smoothing factor of 0,5 .

First, samples with higher pollen concentrations are usually those from calmer environments and low oxygenated waters may favor pollen preservation, as oxidation is known as one of the main causes of pollen and organic matter degradation (Campbell, 1999; Rösel et al., 2012). Second, whitewater rivers characteristically present low pollen concentrations, as well as they intensely rework their margins and bars, and tend to have larger floodplain areas (Archer, 2005). Thus, pollen deposited on the floodplains are subjected to subaerial exposition and then can be reincorporated to the fluvial load again by surface runoff, flooding, or bank erosion. Wet-dry cycles alternation is recognized by Campbell (1991) as one of the main factors responsible for weakening of the pollen wall. Third, saprophytic fungi and microbial attack are documented as agents responsible for the corrosion of sporopollenin, which in turn, make the grain wall more susceptible to 
degradation by mechanical, chemical and other biochemical damages (Goldstein, 1960; Elsik, 1966; Rösel et al., 2012; Wurzbacher et al., 2014). Whitewater rivers sediments are usually richer in fungi spores, which can make up to $85 \%$ of the total palynomorphs (sum of pollen and all spore types), while sediments from blackwater rivers are among the poorest (Figure 24). Regardless of the vast richness of fungi, its diversity, ecological distribution and habits are still poorly known (Cortez, 2016), which makes it hard to quantify the effect of this agent to pollen degradation in the overall assemblage.

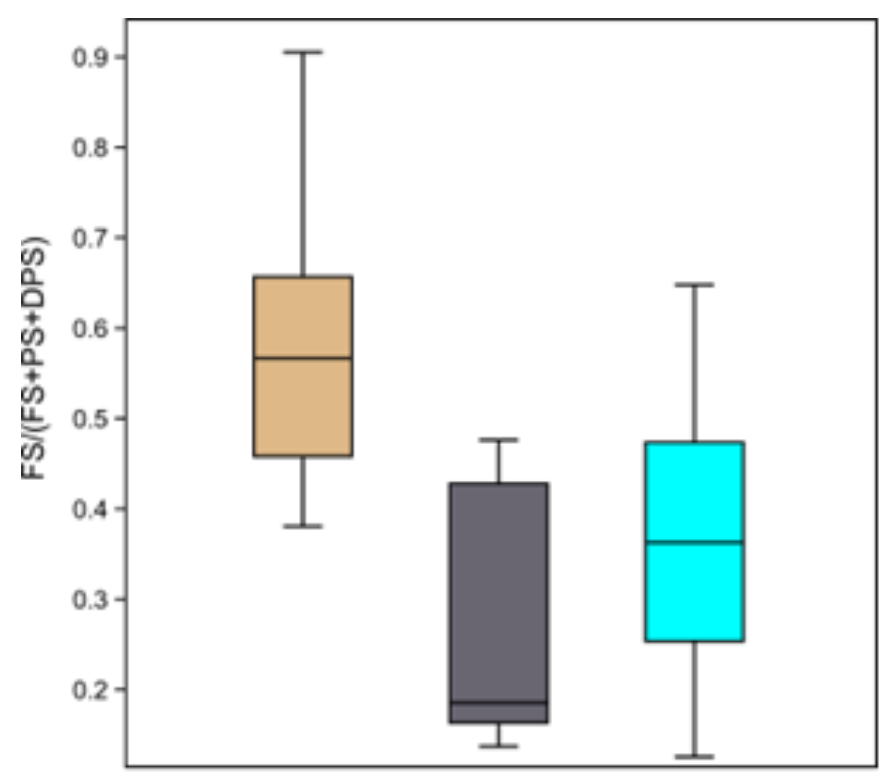

whitewater blackwater clearwater

Figure 24 - Contribution of fungi spores according to water type (FS = Fungi Spores; PS = total of Pollen and Pteridophyte Spores; DPS = Damaged Pollen and Spores).

Fourth, mechanical damage alone, as a result of collision between grains, was laboratory proven to have a minor destructive effect on sporopollenin (Campbell, 1991), although this might not be true on an already weakened grain wall. Fifth, high values of pollen degradation are usually found in sediments with coarser grain size for most of samples (Figure 25), which is similar to the pattern observed by Sun et al. (2017) for lignin degradation in riverbed sediments that points out to the role of the fine sediment matrix in isolating and preserving the organic matter.

A combination of these factors is the most probable answer for the observed pattern of pollen degradation, though how each one affects the assemblage is hard to quantify. 
Increasing downstream pollen degradation may reflect longer transport and exposure to all those damaging factors.

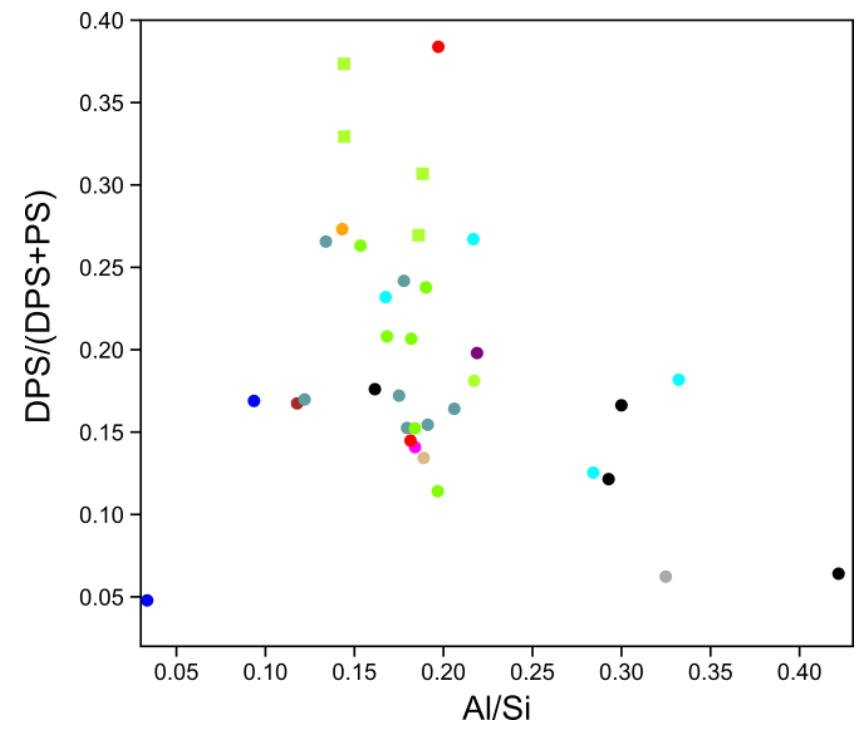

Figure 25 - Correlation between grain size and damaged pollen and spores. Solimões (darkgreen), Amazonas (lightgreen), Amazon estuary (lightgreen squares), Negro (black), Xingu (cyano), Madeira (red), Tapajós (blue), Coari (purple), Tefé (gray), Purus (pink), Juruá (orange), Japurá (dark brown), Içá (light brown).

\subsubsection{Reworked Fossil Palynomorphs}

The released material from Paleozoic rocks and Neogene riverbanks is transported to the river channel and incorporated into the modern register. The sporadic presence of Grimsdalea clavata $(<0.5 \%)$, a guide fossil from Miocene-Pliocene (Hoorn, 1993), in sediments from Solimões and Amazonas rivers highlights the incorporation of reworked fossil grains to the modern registry. This taxon is found in Neogene sedimentary rocks in northern South America (Pocknall and Jarzen, 2012) and is registered in riverbank outcrops such as the Solimões Formation in the west flank of Purus Arch (Latrubesse et al., 2007; Nogueira et al., 2013) and Novo Remanso Formation in east flank (Dino et al., 2012).

Acritarchs, such as Veryachium and Ammonidium, are present in sediments from Japurá, Juruá, Solimões, Madeira, and Amazonas rivers. These microfossils are freed from eroded rocks and carried in suspension with sediments by the rivers. The contribution 
of acritarchs is lower than $0.4 \%$ in the western tributaries and Solimões River, and considerably rises in the eastern Amazonas River samples (0.5-2.8\%), whereas Madeira River sediments register the highest percentages of acritarchs (5.5-7\%). These acritarchs are Siluro-Devonian guide fossils and their source can be traced to outcropping Paleozoic units in the Peruvian and Bolivian Andes (e.g. Vavrdová et al., 2011) and the northern part of the Amazon River trough, such as those crossed by Trombetas River (e.g. Oliveira and Lima, 1990). The Trombetas and other clearwater rivers, contribute with a negligible amount of sediments and are unlikely to have a great contribution to the observed increase. Madeira River can carry about half of the sediment load of the Amazonas main channel (Meade, 1994), and is probably the major source and cause of increase up to $2.8 \%$ in acritarchs at the downstream reaches of Amazonas River.

\subsection{Blackwater tributaries}

\subsubsection{Negro River}

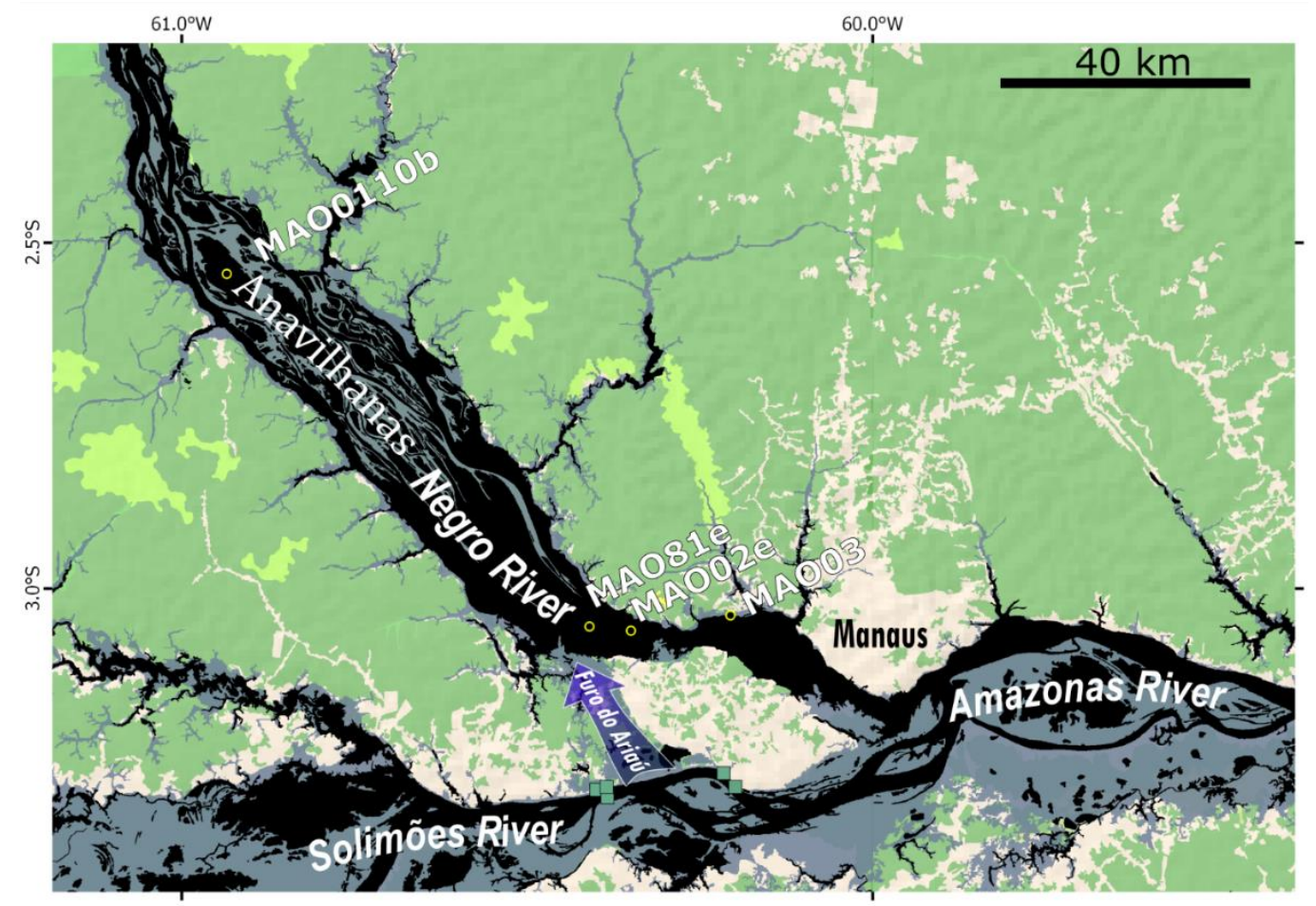

Figure 26 - Negro-Solimões confluence. Samples sites from Negro River indicated by yellow dots. River course during the dry season in black, flooding area in blue. Dense forest in green, open or transitional vegetation in light green, anthropogenically disturbed areas in white. 
Figure 26 shows the sample sites at Negro River. Silt riverbed sediments exhibit pollen concentrations between 41,000 and 68,000 PGS, and a sandy silt sample 17,000 PGS. Sample MAO0110b was collected in a semi-confined lake by the channel bars that build the Anavilhanas archipelago. The palynological assemblage of this sample is characterized by Alchornea (16\%), Moraceae (15\%), Cecropia (14\%), Sapium (10\%), Symmeria (10\%), and Poaceae (6\%). The Anavilhanas sediments are comparatively richer in pollen from riverine taxa, represented by Alchornea, Cecropia, Sapium, Symmeria, Pseudobombax, and Pouteria, than in lower Negro River.

The palynological signature of the lower Negro River, samples MAO03, MAO02e and MAO81e, is marked by Poaceae (13-32\%) as the main pollen type and a relatively lower Alchornea (5-12\%), Cecropia (7-11\%), Sapium (4-9\%), Moraceae (4-7\%), and Symmeria (2-6\%). Taxa with affinity to drier conditions are present and include Mollia, Duroia, Parkia, Byrsonima, Cassia, Bowdichia, and Esenbeckia. In the lower Negro River, there is an increase in Poaceae and Melastomataceae/Combretaceae, and occurrence of taxa absent in Anavilhanas, such as Iriartea, Attalea, Schefflera, and Virola.

The development of Anavilhanas' archipelago relates to the influx of sediments from the Branco River and during the flood season the islands are inundated for two months providing a passage for water and transported materials over these lakes (Adis, 1984; Franzinelli and Igreja, 2002). Thus, Anavilhanas' palynological content reflects a dominant local component composed by igapó forest elements, while a long-distance transported component is greater in the lower Negro River samples, evidenced by the rising of grass pollen (Poaceae) accompanied by an increase of pollen from a drier vegetation and absence of várzea herbs.

\subsubsection{Tefé River}

Sample MAO149, collected in the lower reaches of Tefé River, contains mineralogical mature sediments similar to those of the Negro River, indicated by $\mathrm{Al} / \mathrm{K}$ and $\mathrm{Ti} / \mathrm{Fe}$ ratios, which suggests no sedimentary influx from the Solimões River in this site (Figure 19Figure 20). The lack of pollen commonly found in whitewater rivers, such as those from altitude vegetation or whitewater várzea, supports no mixing. Its palynological signature is composed mainly of Symmeria (22\%), Cecropia (20\%), Alchornea (14\%), 
Moraceae (8\%), and Myrtaceae (6\%). Flooded forest taxa also include Pouteria, Luehea, Piranhea, Crudia and Virola. Terra firme taxa are scarcely represented by Piptadenia, Schefflera, Theobroma, Chrysobalanaceae and Bignoniaceae.

\subsubsection{Coari River}

Sample MAO135 was collected at Coari-lake, near the homonymous city and close to the confluence with Solimões River and exhibits high pollen concentration $\sim 66,200$ PGS. Both geochemical and palynological signatures point to a prevailing Solimões River sedimentation. This sample shows low $\mathrm{Al} / \mathrm{K}$ ratio (Figure 20 ) characteristic of mineralogical immature sediments transported by whitewater rivers. The Solimões River input causes an increase of Cecropia and appearance of Hedyosmum, Iriartea, Acalypha, and Alternanthera, frequent taxa in whitewater várzea. Cecropia (34\%) and Moraceae $(13 \%)$ are the most common pollen types, followed by Poaceae (9\%), Cyperaceae (8\%) and Symmeria (7\%). Cyperaceae, Symmeria, Piranhea, and Sapium, mostly reflect the local igapó vegetation, since these types are typical of lakes and stable flooded environments, and occur in higher percentages than in Solimões riverbed sediments. Terra firme taxa includes Piptadenia, Hieronyma, and Copaifera. This sample is the only that contains Pediastrum, representing about $3 \%$ of the total palynomorphs (excluding fungi).

\subsubsection{Overall aspects}

Tefé and Anavilhanas sediments show a higher palynological similarity and better reflect a typical blackwater river pollen signature. Symmeria (10-22\%), Sapium (3-10\%), Amanoa (0-2\%), Pouteria (2\%), Piranhea (1-2\%), and abundance of Myrtaceae (4-6\%) are characteristic of igapó forests. Pioneer herbaceous colonists and floating meadows are unlikely to have a considerable contribution to the palynological signature, due to low levels of suspended sediments and dissolved nutrients under acidic conditions that prevent the thriving of these plants (Kalliola et al., 1991; Archer, 2005). In fact, there is a low diversity and contribution from várzea herbs to the pollen spectra. Therefore, the low Poaceae values of Anavilhanas and Tefé are more likely to match an igapó signature. Pollen from terra firme forest exhibit a rich diversity exampled by Scleronema, Theobroma, 
Schefflera, Trattinnickia, Rutaceae, Meliaceae, and several genera of Fabaceae. The pollen percentages of riverbed samples of blackwater tributaries are shown in Table 2.

Table 2 - Percentage representation of pollen in blackwater tributaries riverbed sediments.

\begin{tabular}{|c|c|c|c|c|c|c|}
\hline Taxon & $\begin{array}{c}\text { MA0149 } \\
\text { Tefé } \\
(\%)\end{array}$ & $\begin{array}{c}\text { MA0135 } \\
\text { Coari } \\
(\%)\end{array}$ & $\begin{array}{c}\text { MA00110b } \\
\text { Anavilhanas } \\
(\%)\end{array}$ & $\begin{array}{c}\text { MAO81e } \\
\text { L. Negro } \\
(\%)\end{array}$ & $\begin{array}{l}\text { MAO02e } \\
\text { L. Negro } \\
(\%)\end{array}$ & $\begin{array}{c}\text { MAO03 } \\
\text { L. Negro } \\
(\%)\end{array}$ \\
\hline Cecropia & 20.0 & 33.7 & 14.0 & 7.3 & 6.7 & 11.4 \\
\hline Alchornea & 14.0 & 4.3 & 15.7 & 5.6 & 12.3 & 7.8 \\
\hline Symmeria & 21.9 & 7.3 & 10.1 & 2.4 & 4.8 & 5.8 \\
\hline Moraceae & 8.5 & 12.5 & 14.7 & 5.8 & 6.7 & 3.9 \\
\hline Sapium & 3.0 & 0.4 & 10.1 & 5.1 & 8.8 & 4.3 \\
\hline Myrtaceae & 5.8 & 2.6 & 4.2 & 3.4 & 4.2 & 1.3 \\
\hline Melast/Combr & 2.2 & 2.1 & 2.7 & 4.7 & 6.1 & 2.4 \\
\hline Pouteria & 2.2 & - & 2.0 & 1.3 & 0.4 & - \\
\hline Piranhea & 1.4 & 0.9 & 1.7 & 0.2 & 0.4 & 0.5 \\
\hline Amanoa & - & - & 2.0 & 1.9 & 2.9 & 3.6 \\
\hline Lecythidaceae & - & - & 0.5 & 0.2 & 0.6 & 1.4 \\
\hline Mauritia & 0.5 & 0.2 & 0.2 & 1.7 & - & 0.6 \\
\hline Iriartea & - & 0.6 & - & 1.9 & 1.0 & 0.6 \\
\hline Poaceae & 3.6 & 9.2 & 6.1 & 21.6 & 12.8 & 31.6 \\
\hline Asteraceae & 0.5 & 1.1 & 1.0 & 0.2 & 0.4 & 0.5 \\
\hline Cyperaceae & - & 7.7 & 1.2 & 1.3 & 1.5 & 1.5 \\
\hline
\end{tabular}

\subsection{Clearwater tributaries}

Samples from Tapajós and Xingu rivers are indicated in the Figure 27 and the pollen percentages in Table 3. Both clearwater rivers flow northwards and have its headwaters in the cerrado and cratonic domains. Tapajós samples are located at both margins of the lower reaches of the ria and the Xingu samples distributed along the river, XA30 locates at the Xingu-Amazonas confluence in an area strongly influenced by Amazonas River. An astonishing feature of this region is what has been called deforestation fishbone pattern (white), in which the Trans-Amazonian Highway is the backbone from where devastation spreads. 


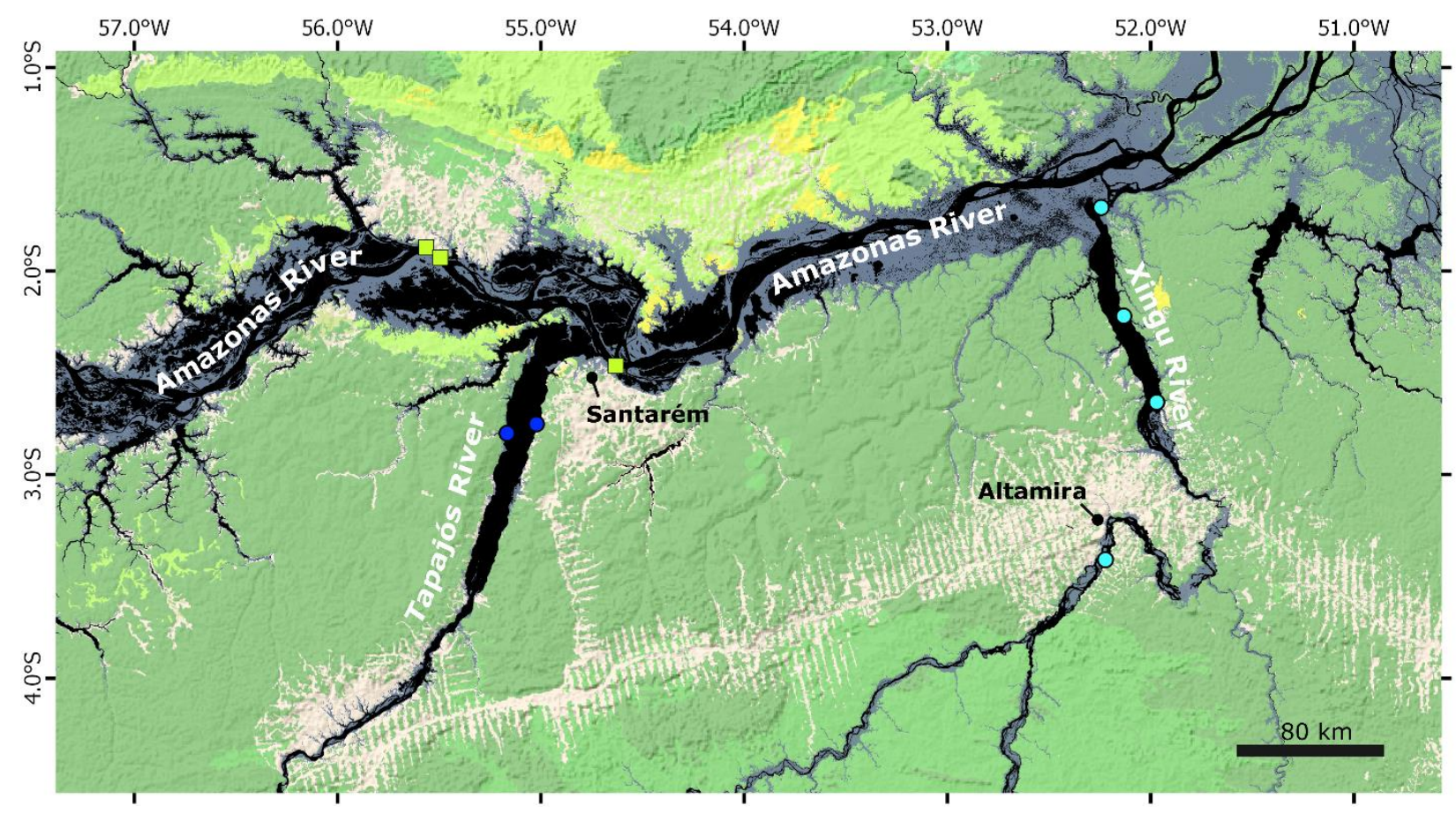

Figure 27 - Samples from Xingu River shown by light blue dots and from Tapajós River in dark blue. River course during the dry season in black, and floodplain in blue. Forested area in green, ecotone zone in light green and open physiognomy in yellow. Anthropogenic disturbed areas in white, such as occupated areas and the fishbone pattern.

\subsubsection{Tapajós River}

The Tapajós River samples contain riverbed silty sands collected near each margin of the ria and about $70 \mathrm{~km}$ upstream the confluence (Figure 27). These samples are characterized by low pollen concentrations 1,800-2,200 PGS and their pollen assemblages consist of Poaceae (28-41\%) and Ambrosia (9-19\%) as the most common pollen types, followed by Cecropia (8\%), Moraceae (6-7\%), Alchornea (4-7\%) and Cyperaceae (1-5\%). Other floodplain taxa include Symmeria, Alternanthera, Mauritia, Virola, Sapium, Crudia, and Acalypha. Terra firme is poorly represented by Symphonia, Schefflera, Tapirira, Copaifera, Hieronyma and Proteaceae.

Palynological spectra exhibit an overrepresentation of Poaceae accompanied by the presence of other várzea herbs, such as Ambrosia, Cyperaceae, Alternanthera, Acalpyha, under a closed-forest regional vegetation context. These herbs are pioneers that colonize river banks and levees, widely represented in the floodplain vegetation (Kalliola et al., 1991; Junk and Piedade, 1993). Pollen common in the Amazon River, such 
as Iriartea and Ilex are present. One Podocarpus pollen grain was found, and might suggest a contribution from Central Brazil (Ledru et al., 2007) or from an Amazon River backflow (Fricke et al., 2017). The proximity to the margin may enhance the influence of the local riverbank vegetation.

\subsubsection{Xingu River}

Sediment samples from Xingu River are rich in pollen, ranges from 18,000 to 51,000 PGS, and overrepresentation of Cecropia is a characteristic feature. Samples XA42 and XA36 have Cecropia (38-39\%), Symmeria (9.5\%), and Melastomataceae/Combretaceae (6-7\%) as the most frequent pollen types. Genipa (6\%) and Myrtaceae (4.5\%) are more important in XA42 and decrease in importance downstream. Sample XA25 is characterized by the highest percentage of Cecropia (53\%), followed by Alchornea (6\%) and Symmeria (5\%); in this sample Alchornea (6\%), Atallea, and Schefflera scores the highest values. In Xingu, floodplain taxa also include Piranhea, Pseudobombax, Sapium, Mauritia, Crudia, Amanoa, Manilkara, Zanthoxylum, and Tabebuia. These taxa characterize a seasonally flooded forest; indicate more stable margins and a mature igapó vegetation.

Terra firme is represented by Piptadenia, Hieronyma, Schefflera, Cupania, Celtis, Copaifera, Dalbergia, Anadenanthera, Dinizia, Banisteriopsis, Cheiloclinium, and Elaeis?. Taxa indicative of a drier vegetation are present, such as Borreria, Cassia, Cenostigma, Mollia, Canavalia, Byrsonima, Parkisonia, Roupala. Hyperdominant Amazonian taxa include Licana and Protium. Samples XA36 and XA25 have slightly higher values of Poaceae (3\%) than the most upstream sample XA42 (1\%), which might be consequence of pastures of the fishbone deforested zone, represented in white in Figure 27 (Photo 11).

Sample XA30, collected at the Xingu confluence, indicates a major influence from the Amazon River by a distinct increase in herb pollen (Poaceae, Cyperaceae) and other types commonly found in sediments from the mainstem. Cecropia (34\%) and Poaceae $(21 \%)$ make up the main types in the assemblage, followed by Cyperaceae $(4 \%)$, Moraceae, and Symmeria. Appearance of taxa such as Acalypha, Alternanthera, Ilex, Virola, and Ericaceae evidence the input from the Amazon River. 


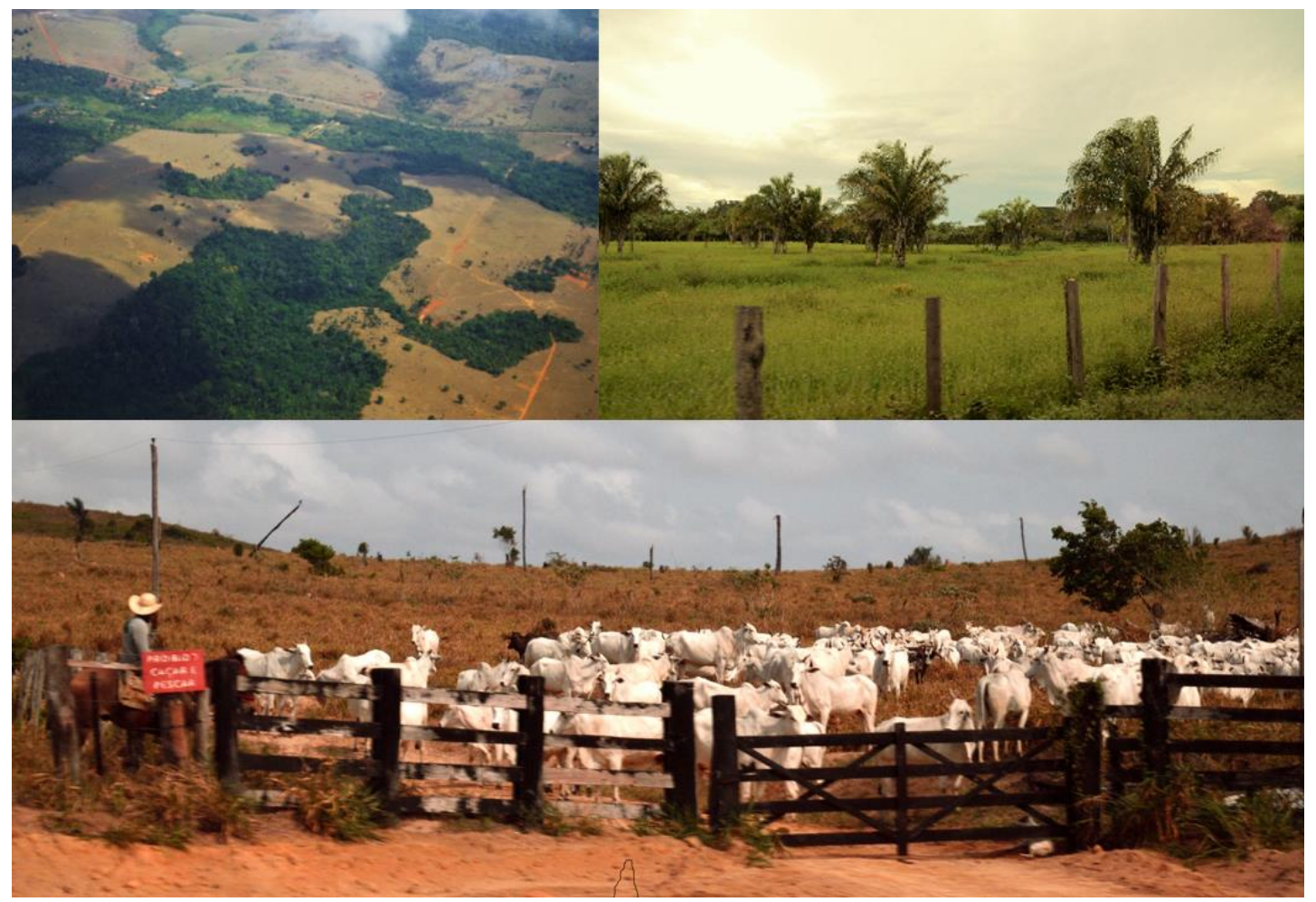

Photo 11 - Deforested areas for pasture in Altamira region. A. Aerial view. B. Attalea palms growing on a deforested area. C. Pastures for cattle ranching. Photos: Thomas Akabane.

Table 3 - Percentage representation of pollen in clearwater tributaries riverbed sediments.

\begin{tabular}{lcccccc}
\hline \multicolumn{1}{c}{ Taxon } & $\begin{array}{c}\text { STM12 } \\
\text { Tapajós } \\
(\%)\end{array}$ & $\begin{array}{c}\text { STM14 } \\
\text { Tapajós } \\
(\%)\end{array}$ & $\begin{array}{c}\text { XA42 } \\
\text { Xingu } \\
(\%)\end{array}$ & $\begin{array}{c}\text { XA25 } \\
\text { Xingu } \\
(\%)\end{array}$ & $\begin{array}{c}\text { XA36 } \\
\text { Xingu } \\
(\%)\end{array}$ & $\begin{array}{c}\text { XA30 } \\
\text { Xingu-Conf } \\
(\%)\end{array}$ \\
\hline Cecropia & 7.8 & 8.1 & 37.7 & 52.9 & 38.7 & 34.6 \\
Symmeria & 0.4 & 3.7 & 9.4 & 5.2 & 9.5 & 2.9 \\
Melast/Combr & 2.5 & 4.4 & 7.7 & 4.0 & 5.9 & 2.9 \\
Alchornea & 3.7 & 7.4 & 2.9 & 6.4 & 4.0 & 2.6 \\
Moraceae & 5.7 & 7.4 & 2.6 & 3.4 & 2.6 & 3.2 \\
Myrtaceae & - & 0.7 & 4.5 & 3.4 & 2.6 & 2.1 \\
Piranhea & - & - & 4.2 & 4.0 & 3.5 & 1.2 \\
Genipa & - & - & 6.0 & 0.3 & 0.4 & - \\
Sapium & 0.4 & 0.7 & 0.3 & 0.8 & 0.9 & 0.9 \\
Schefflera & 1.2 & 3.0 & 0.2 & 1.0 & 0.8 & - \\
Attalea & - & - & 0.8 & 1.3 & 0.9 & 0.3 \\
Mauritia & 1.2 & - & 0.2 & - & 0.5 & 0.6 \\
Poaceae & 40.2 & 28.1 & 1.1 & 3.0 & 3.3 & 20.5 \\
Asteraceae & 9.0 & 18.5 & 0.5 & 0.8 & 0.5 & 0.9 \\
Cyperaceae & 5.3 & 1.5 & 0.8 & 1.0 & 3.1 & 4.1 \\
Alternanthera & 0.4 & 1.5 & - & - & - & 0.3 \\
\hline
\end{tabular}




\subsection{Whitewater Tributaries}

Samples from whitewater tributaries are shown in Figure 28 and pollen percentages in Table 4.

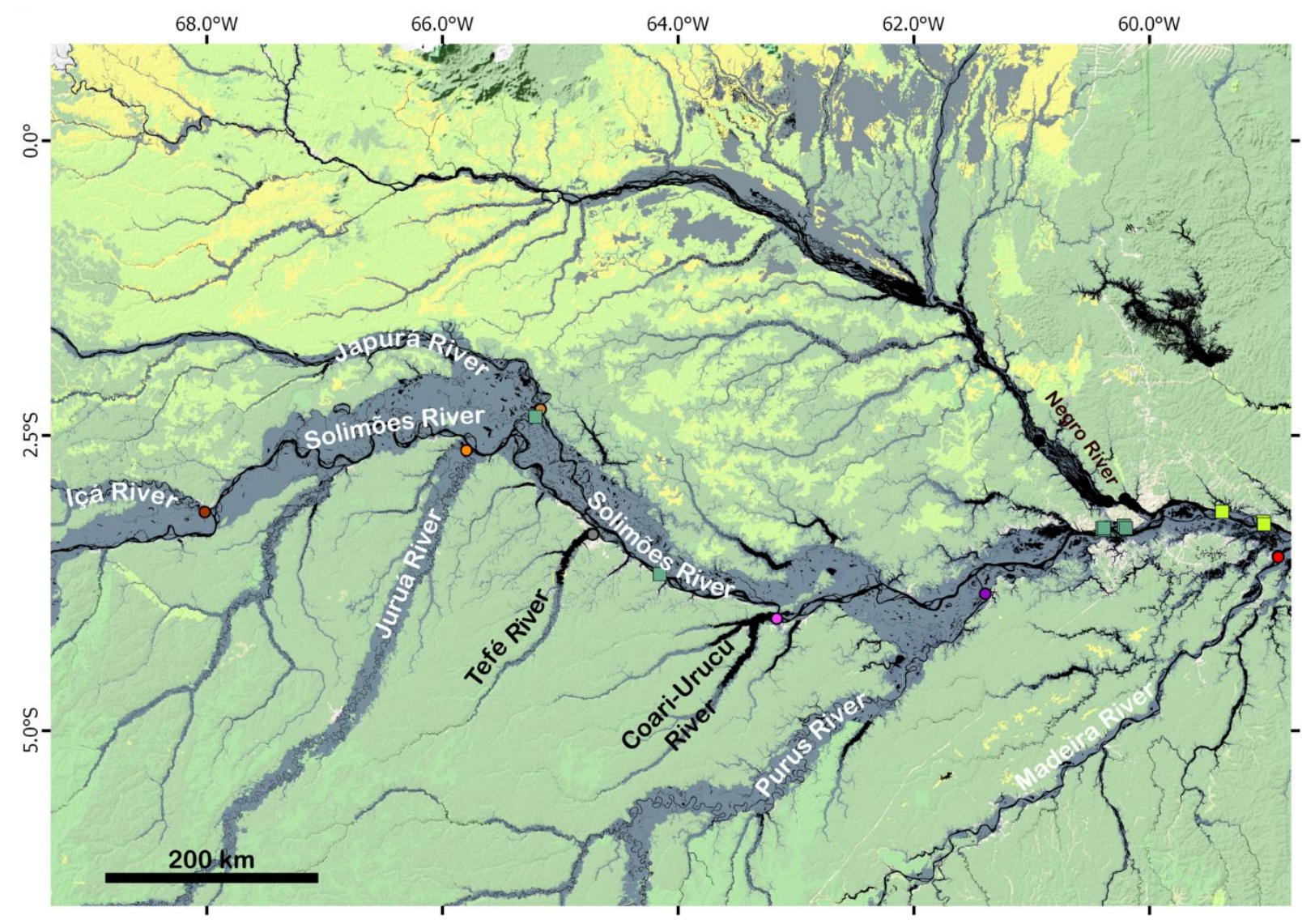

Figure 28 - Whitewater tributaries and Solimões River in white labels. River course during the dry season in black, and during high water levels in blue. Forested area in green, ecotone zone in light green and open physiognomy in yellow. Anthropogenic disturbed areas in white.

\subsubsection{Içá River}

The sample MAO172, containing sandy silt sediment from Içá River, exhibits low pollen concentration despite the finer grain size, which may be result of high amounts of suspended sediments. Because of that, a satisfactory quantity of pollen grains could not be counted. The assemblage mainly consists of Cecropia, Melastomataceae Combretaceae, Asteraceae, Alchornea, Symmeria, and Myrtaceae. Pollen from terra firme vegetation includes Piptadenia and Meliaceae. Montane vegetation is represented by Hedyosmum. 


\subsubsection{Japurá River}

Sample MAO186 contains silty sand sediments with low pollen concentration. The palynological content is dominated by Cecropia (32\%), Melastomataceae/Combretaceae (5\%) followed by others várzea elements such as Iriartea, Alchornea and Mauritia. Herbaceous vegetation is represented in low percentages and includes Asteraceae, Poaceae, Convolvulaceae, Brassicaceae. Terra firme taxa include Schefflera, Hieronyma, Tournefortia, Lecythidaceae, Sapindanceae. Long-distance transported taxa from Andean regions include Hedyosmum (3.6\%) and Alnus (0.4\%). An unidentified tricolporate pollen type is abundant $\sim 16 \%$.

\subsubsection{Juruá River}

The pollen assemblage of Juruá River is dominated by várzea taxa such as Cecropia (44\%), followed by Alchornea (10\%), Symmeria (5\%), and Poaceae (4\%). Floodplain taxa belonging to Iriartea (3\%), Ilex, Pseudombax and Mauritia are also present. Montane taxa include Hedyosmum and Podocarpus.

\subsubsection{Purus River}

The Purus River sample exhibits overrepresentation of Cecropia (44\%) and an important contribution of Alchornea (8\%), Poaceae (7\%) and Symmeria (4\%). Taxa common in floodplain include Iriartea, Ilex, and Pseudobombax, and indicators of a mature forest are present, such as Piranhea, Sapium, and Amanoa, typically found in riverbed sediments from sites surrounded by a stable igapó forest.

\subsubsection{Madeira River}

Madeira River samples (MAO25e and MAO25b) were collected at about $23 \mathrm{~km}$ upstream of the confluence. Because a satisfactory pollen count was not possible, the results are given as a compound of two samples in order to obtain a better representativeness. The resulting pollen assemblage is mainly made of Cecropia (23\%), Poaceae (9.5\%), Iriartea (9.5\%), Hedyosmum (7\%), and Moraceae (5.5\%). Lower abundance of pollen from várzea trees include Symmeria, Alchornea, and Virola. Terra 
firme taxa is poorly represented by a few occurrences of Piptadenia, Anadenanthera, Acacia, and Alibertia. Montane taxa also include Alnus. Contribution of Poaceae is higher in Madeira River than in others whitewater tributaries, and is accompanied by other herbs, such as Asteraceae, Cyperaceae, Alternanthera, Acalypha and Gomphrena.

\subsubsection{Overall aspects}

The palynological assemblage of whitewater tributaries exhibit dominance of Cecropia (23-44\%), and important contribution of Alchornea (3-10\%), Melastomataceae/Combretaceae (2-4\%), Moraceae (3-6\%), Iriartea (4-7\%), and Symmeria (3-4\%). Poaceae (2-9\%) and Asteraceae (1-5\%) are frequent, other herbs are generally present in low percentages and include Cyperaceae (0-3\%), Alternanthera, and Acalypha. Presence of montane taxa is characteristic of these rivers, represented by Hedyosmum (0-7\%), Alnus (0-2\%), Podocarpus, and Neosprucea.

Table 4 - Percentage representation of pollen in whitewater tributaries riverbed sediments. $\left({ }^{*}\right)$ Percentages based on less than 200 pollen couting $\left(^{* *}\right)$ Madeira values correspond to the integrate values of MAO25e and MAO25b.

\begin{tabular}{lccccc}
\hline \multicolumn{1}{c}{ Taxon } & $\begin{array}{c}\text { MAO172* } \\
\text { Içá } \\
(\%)\end{array}$ & $\begin{array}{c}\text { MAO186 } \\
\text { Japurá } \\
(\%)\end{array}$ & $\begin{array}{c}\text { MAO158 } \\
\text { Juruá } \\
(\%)\end{array}$ & $\begin{array}{c}\text { MAO124 } \\
\text { Purus } \\
(\%)\end{array}$ & $\begin{array}{c}\text { MAO25** } \\
\text { Madeira } \\
(\%)\end{array}$ \\
\hline Cecropia & 32.1 & 32.0 & 44.4 & 43.9 & 23.3 \\
Alchornea & 5.1 & 3.6 & 10.1 & 8.1 & 3.4 \\
Melast/Combr & 15.4 & 5.0 & 2.6 & 2.2 & 4.3 \\
Symmeria & 5.1 & 2.9 & 4.9 & 4.1 & 3.0 \\
Moraceae & 1.3 & 4.3 & 3.5 & 3.3 & 5.6 \\
Myrtaceae & 5.1 & 1.8 & 1.2 & 1.0 & - \\
Virola & 0.0 & 0.0 & 0.7 & 0.6 & 2.6 \\
Iriartea & 3.8 & 4.3 & 3.4 & 0.8 & 9.5 \\
Mauritia & - & 2.5 & 0.3 & - & - \\
Poaceae & 1.3 & 1.8 & 4.3 & 7.3 & 9.5 \\
Asteraceae & 5.1 & 2.2 & 1.4 & 1.2 & 3.4 \\
Cyperaceae & - & 0.0 & 3.0 & 2.4 & 3.0 \\
Ilex & - & 0.0 & 0.4 & 0.6 & - \\
Hedyosmum & 1.3 & 3.6 & 0.3 & - & 6.9 \\
Alnus & - & 0.4 & - & - & 0.9 \\
Podocarpus & - & - & 0.1 & - & - \\
\hline
\end{tabular}




\subsection{Amazon River}

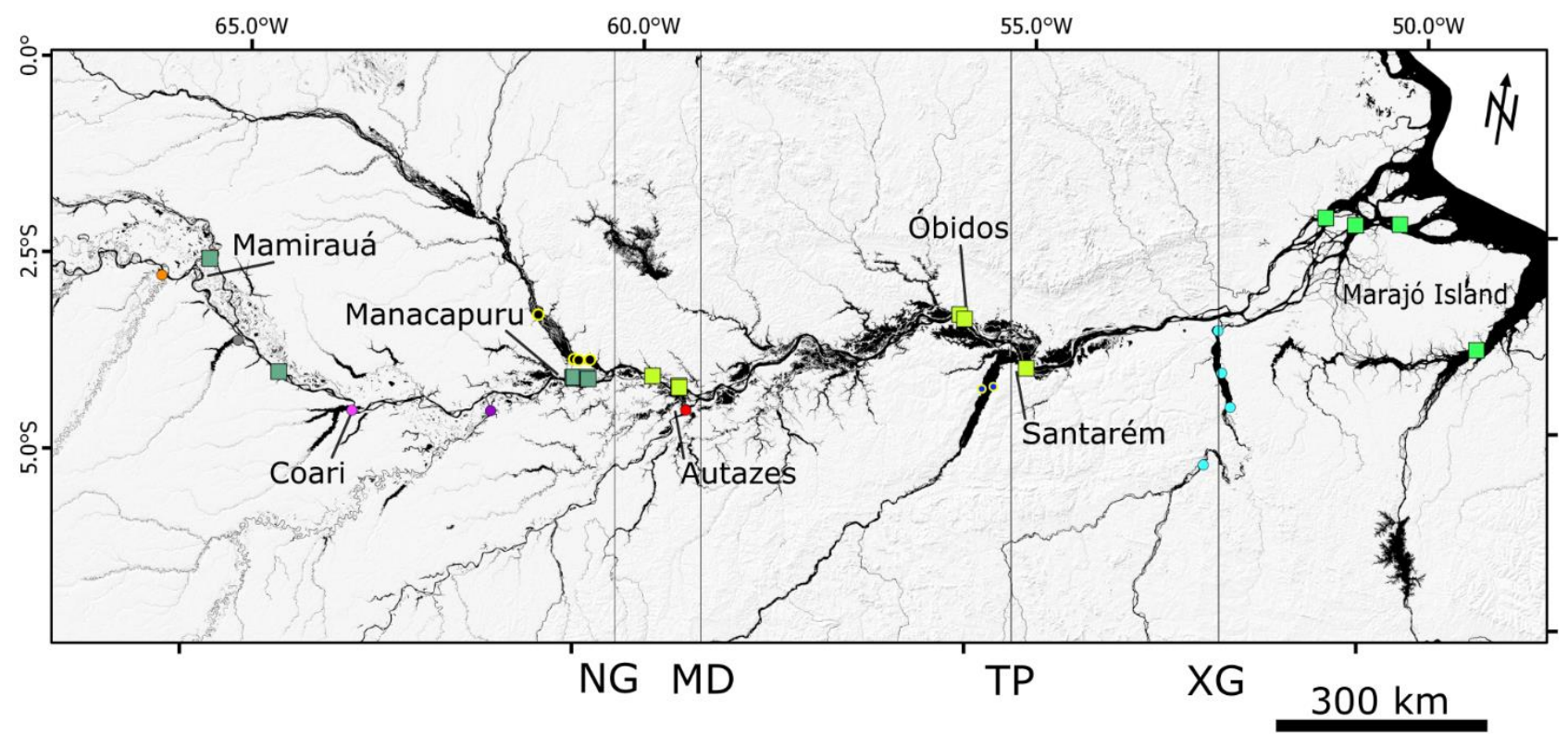

Figure 29 - Sample sites along the Amazon River and tributaries. Places where the major tributaries intercept the mainstem are indicated as NG (Negro), MD (Madeira), TP (Tapajós), and XG (Xingu).

The location of the sediment samples collected in Solimões and Amazonas rivers is shown in Figure 29, pollen percentages in Figure 30, and pollen percentages of each sample in Table 5 and Table 6. Pollen concentrations of Solimões River, Amazonas River, and the Amazon Estuary respectively ranges from 2,000-24,000 PGS; 1,600-23,000 PGS; and 1,900-6,500 PGS. Modern palynological spectra of the Solimões-Amazonas River is dominated by Cecropia (19-52\%) and Poaceae (5-13\%). Others important taxa include Alchornea (2-7\%), Melastomataceae/Combretaceae (3-10\%), Cyperaceae (0-5\%), Iriartea (1-5\%), Symmeria (1-3\%), Asteraceae (1-6\%), and Mauritia (0-3\%). In the downstream direction, there is a decrease in Cecropia, Melastomataceae/Combretaceae, Mauritia, and Moraceae/Urticaceae pollen. Conversely, taxa such as Poaceae, Cyperaceae, Asteraceae, and Arecaceae, show a progressive increase towards the lower reaches. All samples contain Alchornea and no trend is observed, probably because the contribution comes from several distinct sources.

The contribution of herbs is $\sim 13 \%$ at Solimões River, rises to $\sim 17 \%$ after the confluence with Negro River, and reach values up to $\sim 26 \%$ in the Óbidos region, near the confluence with Tapajós River. At the estuary, there is a decrease in Poaceae and 
increase in Cyperaceae, and a small reduction in the total herbs contribution to $\sim 24 \%$. Asteraceae and Cyperaceae are constantly present in the pollen assemblages, other herbs include Amaranthus, Alternanthera, Acalypha, Hyptis, Ipomoea, Begonia, Microtea, Polygonum, Phyla, and Elephantopus. The greatest diversity and contribution of herbs occurs at the lower reaches of Amazon River, in the Óbidos region, where the floodplain area occupied by grasslands and several patchy lakes increase.

Taxa common of late successional stages to climax forest, present in low percentages, include Piranhea, Tabebuia, Virola, Pseudobombax, Ilex, Sapium, Luehea, Zollernia, and Pouteria pollen. Symmeria pollen indicates calmer and less disturbed environments, such as floodplain-lakes or rias, and is slightly more abundant between the Negro and Madeira confluences.

Terra firme taxa exhibit sporadic occurrences and a rich diversity, the overall contribution are usually less than $15 \%$ of the total assemblage and include Licania, Protium, Banisteriopsis, Schefflera, Symphonia, Dicranostyles, Dalbergia, Janusia, Celtis, Hieronyma, Serjania, Piptadenia, Cheiloclinium, Mollia, Copaifera, Exellodendron, Trattinnickia, Maytenus, Canavalia, Cedrela, Davilla, Struthanthus, Passifloraceae, Rutaceae, and Fabaceae. Pollen from palms such as Euterpe and Attalea, are rarer and poorly represented in the sediments. Long distance transported grains from the Andean mountains, includes mainly Alnus ( $<1.4 \%$ ) and Hedyosmum ( $<2.4 \%$ ), followed by punctual occurrences of Podocarpus, Neosprucea, Myrsine, Ericaceae and Myricaceae.

The Pará River sample (BLM40) shows larger pollen concentration (22,700 PGS), and higher values of Cecropia (23\%), Poaceae (22\%), and Alchornea (10\%), than the Amazon estuary and absence of some taxa commonly found in Amazon River sediments, such as Iriartea, Alnus and Hedyosmum. Taxa with affinity to drier environments are diverse, represented by Borreria, Canavalia, Senna, Iresine, Byrsonima, and Daphnopsis?, and suggest an important input from the Tocantins River. Despite an inflow from the Amazon River reaches Pará River through the Furo de Breves, the distinguishable geochemical and palynological imprint of the Pará River sample indicate that Amazon River contribution is minor. 


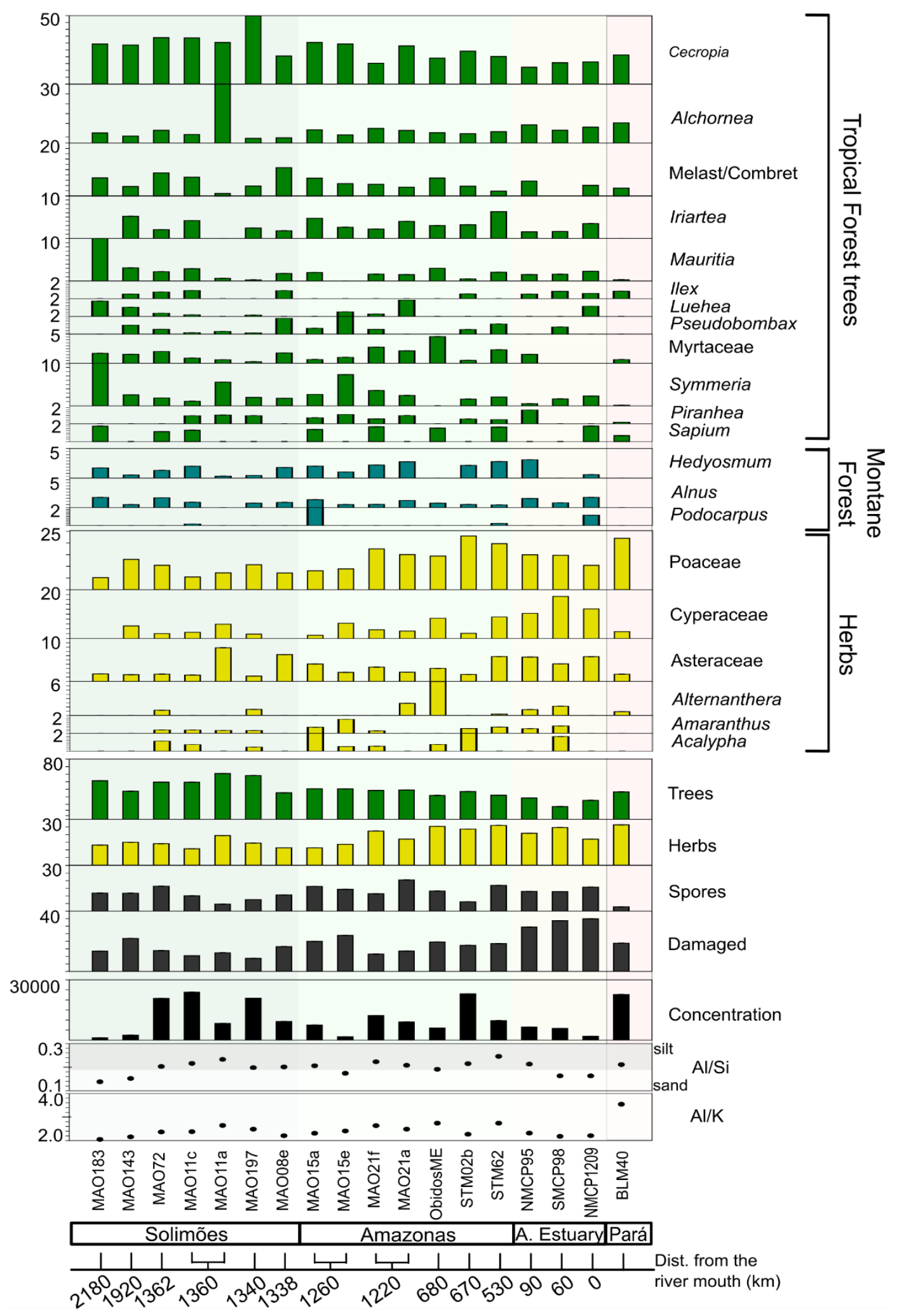

Figure 30 - Pollen diagrams of the Solimões-Amazonas River, grain size: Al/Si ratio, mineralogical maturity: $\mathrm{Al} / \mathrm{K}$ ratio, and distance from the River Mouth $(\mathrm{km})$. Fern spores = Spores/total(Pollen+Spores); Damaged grains $=$ Damaged grains $($ pollen+spores $) /$ total(Pollen+Spores $)$ 
Table 5 - Percentage representation of pollen in Solimões riverbed sediments.

\begin{tabular}{|c|c|c|c|c|c|c|c|}
\hline \multirow[b]{3}{*}{ Taxon } & MA0183 & MAO143 & MAO72 & MAO11c & MAO11a & MA0197 & MAO08a \\
\hline & \multicolumn{2}{|c|}{ Western Solimões } & \multicolumn{3}{|c|}{ E. Solimões River } & \multicolumn{2}{|c|}{ E. Solimões River } \\
\hline & $(\%)$ & (\%) & $(\%)$ & $(\%)$ & (\%) & $(\%)$ & $(\%)$ \\
\hline Cecropia & 36.2 & 28.8 & 35.0 & 34.4 & 30.6 & 51.8 & 19.5 \\
\hline Alchornea & 5.2 & 3.7 & 6.5 & 4.3 & 31.6 & 2.4 & 2.4 \\
\hline Melast/Combr & 6.9 & 3.7 & 8.7 & 7.1 & 1.0 & 3.8 & 9.8 \\
\hline Moraceae & 3.4 & 5.8 & 5.9 & 3.1 & - & 4.6 & - \\
\hline Myrtaceae & 1.7 & 1.6 & 2.0 & 0.9 & 0.7 & 0.3 & 1.6 \\
\hline Symmeria & 12.1 & 2.6 & 1.9 & 1.1 & 5.5 & 2.0 & 1.6 \\
\hline Ilex & - & 0.5 & 0.7 & 0.9 & - & - & 0.8 \\
\hline Sapium & 1.7 & - & 1.1 & 1.3 & - & - & - \\
\hline Pseudobombax & - & 1.0 & 0.6 & 0.2 & 0.3 & 0.2 & 1.6 \\
\hline Piranhea & - & - & - & 0.9 & 1.0 & 0.9 & - \\
\hline Iriartea & - & 5.2 & 2.0 & 4.2 & - & 2.4 & 1.6 \\
\hline Mauritia & 10.3 & 3.1 & 2.2 & 2.9 & 0.7 & 0.3 & 1.6 \\
\hline Schefflera & - & 0.5 & 0.2 & 0.2 & 0.3 & 0.5 & 0.8 \\
\hline Hedyosmum & 1.7 & 0.5 & 1.3 & 2.0 & 0.3 & 0.5 & 1.6 \\
\hline Alnus & 1.7 & 0.5 & 1.7 & 0.9 & - & 0.8 & 0.8 \\
\hline Poaceae & 5.2 & 13.1 & 10.4 & 5.4 & 7.2 & 10.7 & 6.5 \\
\hline Asteraceae & 1.7 & 2.1 & 1.7 & 1.4 & 7.8 & 1.7 & 5.7 \\
\hline Cyperaceae & - & 5.2 & 2.0 & 2.5 & 5.9 & 1.8 & - \\
\hline Alternanthera & - & - & 0.9 & - & - & 1.1 & - \\
\hline Amaranthus & - & - & 0.4 & 0.4 & 0.3 & 0.3 & - \\
\hline Acalypha & - & - & 1.1 & 0.7 & - & 0.5 & - \\
\hline
\end{tabular}

Table 6 - Percentage representation of pollen in Amazonas riverbed sediments

\begin{tabular}{|c|c|c|c|c|c|c|c|c|c|}
\hline \multirow[b]{3}{*}{ Taxon } & MAO15 & MAO21 & ObidosME & STM02b & STM62 & NMCP95 & SMCP98 & NMCP1209 & BLM40 \\
\hline & \multicolumn{2}{|c|}{ C. Amazon River } & \multicolumn{3}{|c|}{ Eastern Amazon River } & \multicolumn{3}{|c|}{ Amazon Estuary } & Pará River \\
\hline & $(\%)$ & $(\%)$ & $(\%)$ & $(\%)$ & $(\%)$ & $(\%)$ & $(\%)$ & $(\%)$ & $(\%)$ \\
\hline Cecropia & 34.7 & 26.5 & 19.5 & 22.7 & 20.4 & 12.1 & 15.2 & 16.9 & 22.7 \\
\hline Alchornea & 6.1 & 8.2 & 5.3 & 4.4 & 5.8 & 9.0 & 6.4 & 7.9 & 10.1 \\
\hline Melast/Combr & 6.5 & 4.6 & 6.8 & 3.4 & 1.9 & 5.5 & - & 3.9 & 2.9 \\
\hline Moraceae & 4.4 & 4.5 & 1.5 & 6.4 & 4.2 & 0.5 & - & 3.4 & 1.6 \\
\hline Myrtaceae & 1.0 & 2.9 & 4.5 & 0.5 & 2.3 & 1.5 & - & - & 0.7 \\
\hline Symmeria & 6.1 & 3.6 & - & 1.5 & 2.1 & 0.5 & 1.6 & 2.2 & 0.2 \\
\hline Ilex & - & - & - & 0.5 & - & 0.5 & 0.8 & 0.6 & 0.8 \\
\hline Sapium & 0.7 & 1.0 & 1.5 & - & 1.6 & - & - & 1.7 & 0.7 \\
\hline Pseudobombax & 1.7 & 0.3 & - & 0.5 & 1.2 & - & 0.8 & - & - \\
\hline Piranhea & 1.0 & 0.9 & - & 0.5 & 0.5 & 1.5 & - & - & 0.2 \\
\hline Iriartea & 4.1 & 3.6 & 3.0 & 3.0 & 6.3 & 1.5 & 1.6 & 3.4 & - \\
\hline Mauritia & 1.0 & 1.9 & 3.0 & 0.5 & 2.1 & 1.5 & 1.6 & 2.2 & 0.3 \\
\hline Schefflera & - & 1.0 & - & - & 0.5 & 0.5 & - & - & 0.2 \\
\hline Hedyosmum & 1.7 & 2.9 & - & 2.0 & 2.8 & 3.0 & - & 0.6 & - \\
\hline Alnus & 1.0 & 1.0 & 0.8 & 0.5 & 0.5 & 1.5 & 0.8 & 1.7 & - \\
\hline Poaceae & 9.9 & 19.2 & 14.3 & 21.2 & 19.7 & 14.6 & 14.4 & 10.1 & 21.6 \\
\hline Asteraceae & 3.4 & 3.3 & 3.8 & 1.5 & 5.8 & 6.0 & 4.0 & 6.2 & 1.6 \\
\hline Cyperaceae & 4.8 & 4.0 & 8.3 & 2.0 & 8.8 & 10.1 & 16.8 & 11.8 & 2.8 \\
\hline Alternanthera & - & 1.2 & 6.0 & - & 0.2 & 1.0 & 1.6 & - & 0.7 \\
\hline Amaranthus & 1.4 & 0.2 & - & - & 0.7 & 0.5 & 0.8 & - & - \\
\hline Acalypha & 1.4 & 0.3 & 0.8 & 2.0 & - & - & 1.6 & - & - \\
\hline
\end{tabular}




\subsection{Pollen Groups}

Figure 32 shows histograms of percentages of pollen types and groups per river. Cecropia (Ce) is the most abundant taxa and as Melastomataceae/Combretaceae (Me), exhibit higher values in the western whitewater tributaries, Solimões and Xingu rivers, and decrease eastwards. Poaceae (Po) pollen is always present in the sediments and its contribution becomes more important in the Lower Negro River samples, middle and lower reaches of Amazonas River, Tapajós and Pará rivers.

Some of the most common pollen types are grouped according to representativeness in each environment, as well as floristic surveys (bibliography). Overrepresented or widely distributed taxa as Cecropia, Poaceae, and Alchornea, or pollen-types with lower taxa resolution, such as Moraceae, Myrtaceae, and Melastomataceae/Combretaceae are excluded from these groups.

Várzea Forest (VF) is represented by Iriartea and Mauritia palms, Ilex, Pseudobombax, and Luehea. This group is usually more abundant in whitewater

tributaries (4-9\%) and the Solimões-Amazonas River (4-6\%), in black and clearwater tributaries the contribution of VF is low $<2 \%$, except in the lower Negro River $\sim 3 \%$, near Manaus.

Várzea herbs group $(\mathrm{VH})$ includes annual and perennial pioneer herbs, such as Asteraceae, Cyperaceae, Alternanthera, Amaranthus, Acalypha, Ipomoea, Microtea, Hyptis, Polygonum. VH progressively increases eastwards along Amazon course and constitutes a major part of the Tapajós River assemblage.

Symmeria (Sy) and Myrtaceae (My) are common constituents of the Amazon Basin palynological signature, and are particularly important in igapó forests, such as in blackwater and Xingu rivers. Igapó forest (IF) is represented by Symmeria and taxa of the late to mature stages of succession such as Piranhea, Sapium, Roupala, Protium, Amanoa, Genipa, or Pouteria. In the Figure 32, Symmeria is represented in a separate column from IF. Rivers with lower sedimentation rates and relatively stable margins, such as Negro, Tefé, and Xingu rivers are richer in IF and in Anavilhanas constitutes the main part of the assemblage. 
Piranhea, Manilkara, Tabebuia, Virola, Pseudobombax, Ilex, Sapium, Amanoa, Luehea Zollernia, Duroia, Virola, Trichilia, Pouteria, Pterocarpus, and Lecythidaceae relate to late-successional stages or mature forests (LM) of high-várzea and igapó forests.

Montane vegetation taxa (MO) is characterized by Alnus and Hedyosmum, with sporadic occurrences of Podocarpus, Myrica, Myrsine, Neosprucea and Ericaceae. MO is present in the Solimões-Amazonas River and whitewater tributaries, usually in low percentages $<3 \%$, except in Madeira River, where it contributes with $\sim 7 \%$ of the total assemblage and is mainly represented by Hedyosmum and Alnus. Low representativity of Podocarpus may result of its bissacate morphology that helps floatation (Hopkins, 1950) and is also very susceptible to mechanical and biological degradation (Goldstein, 1960; Campbell, 1991).

Savanna taxa group (SA) contains genera known to occur in the cerrado, lavrado, capoeiras, and campinaranas, and includes taxa with drier conditions affinity such as Borreria, Byrsonima, Cassia, Mollia, Senna, Bowdichia, Canavalia, Chiococca, Parkisonia, Roupala, Parkia, Esenbeckia, Galactia, Aegiphila, Daphnopsis, Diploon, and Cenostigma.

The relation of VF and IF can distinguish forests of whitewater várzeas from igapó forests (Figure 31), except for Purus River and Tapajós. Tefé, Anavilhanas, and Xingu rivers exhibit the most evident igapó signature. 


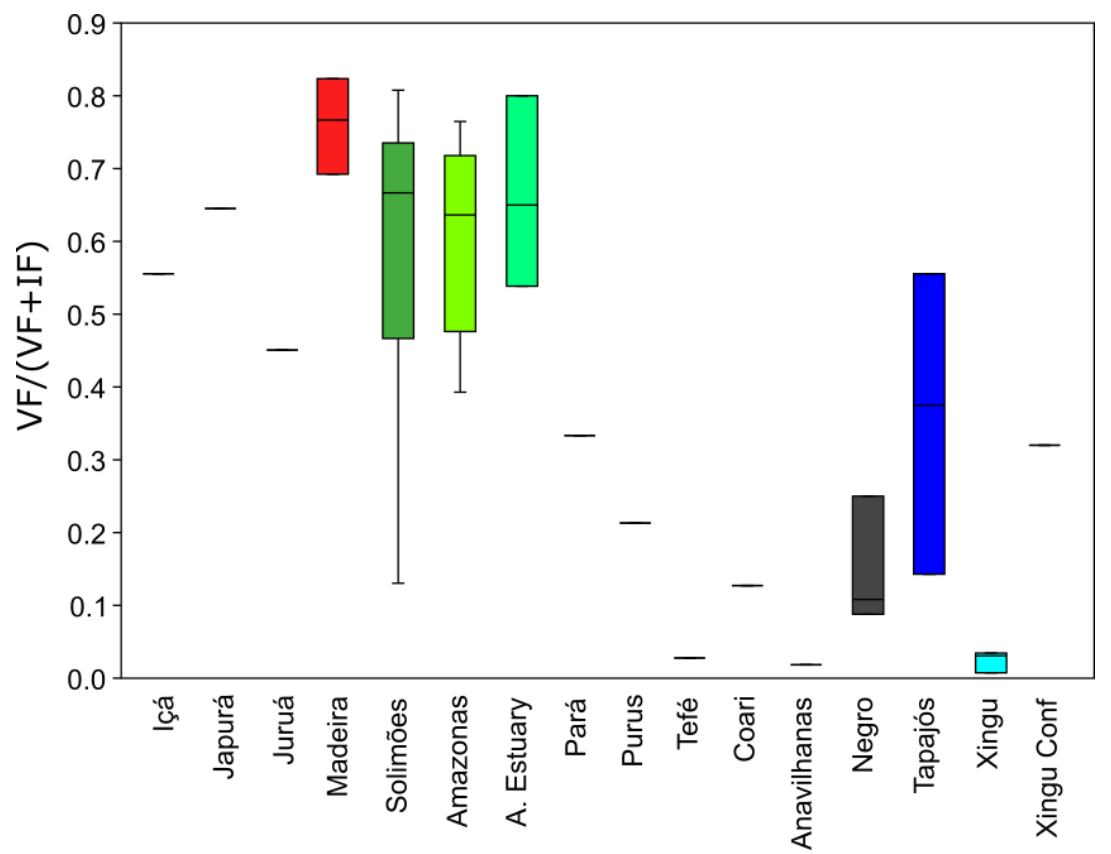

Figure 31 - Boxplot of the relation between várzea (VF) and igapó (IF) forests. The figure ilustrates that whitewater várzeas are dominated by VF and black and clearwater by IF elements. Lower Negro River, Xingu confluence and Tapajós sediments are enriched in taxa typical of várzea.

\begin{tabular}{|l|}
\hline VF = Iriartea + Mauritia + llex + Pseudobombax + Luehea. \\
\hline VH = Asteraceae + Cyperaceae + Alternanthera + Amaranthus + Acalypha \\
\hline IF = Symmeria + Sapium + Piranhea + Pouteria + Amanoa + Genipa. \\
\hline $\begin{array}{l}\text { LM = Piranhea + Pseudobombax + Ilex + Sapium + Amanoa + Luehea + Virola + Zollernia, } \\
\text { Virola + Trichilia + Pouteria + Pterocarpus + Manilkara + Tabebuia + Lecythidaceae } .\end{array}$ \\
\hline MO = Alnus + Hedyosmum + Podocarpus + Myrica + Myrsine + Neosprucea + Ericaceae. \\
\hline $\begin{array}{l}\text { SA = Borreria + Byrsonima + Cassia + Mollia + Senna + Bowdichia + Canavalia + Chiococca + } \\
\text { Parkisonia + Parkia + Esenbeckia + Galactia + Daphnopsis + Diploon + Cenostigma. } .\end{array}$ \\
\hline
\end{tabular}



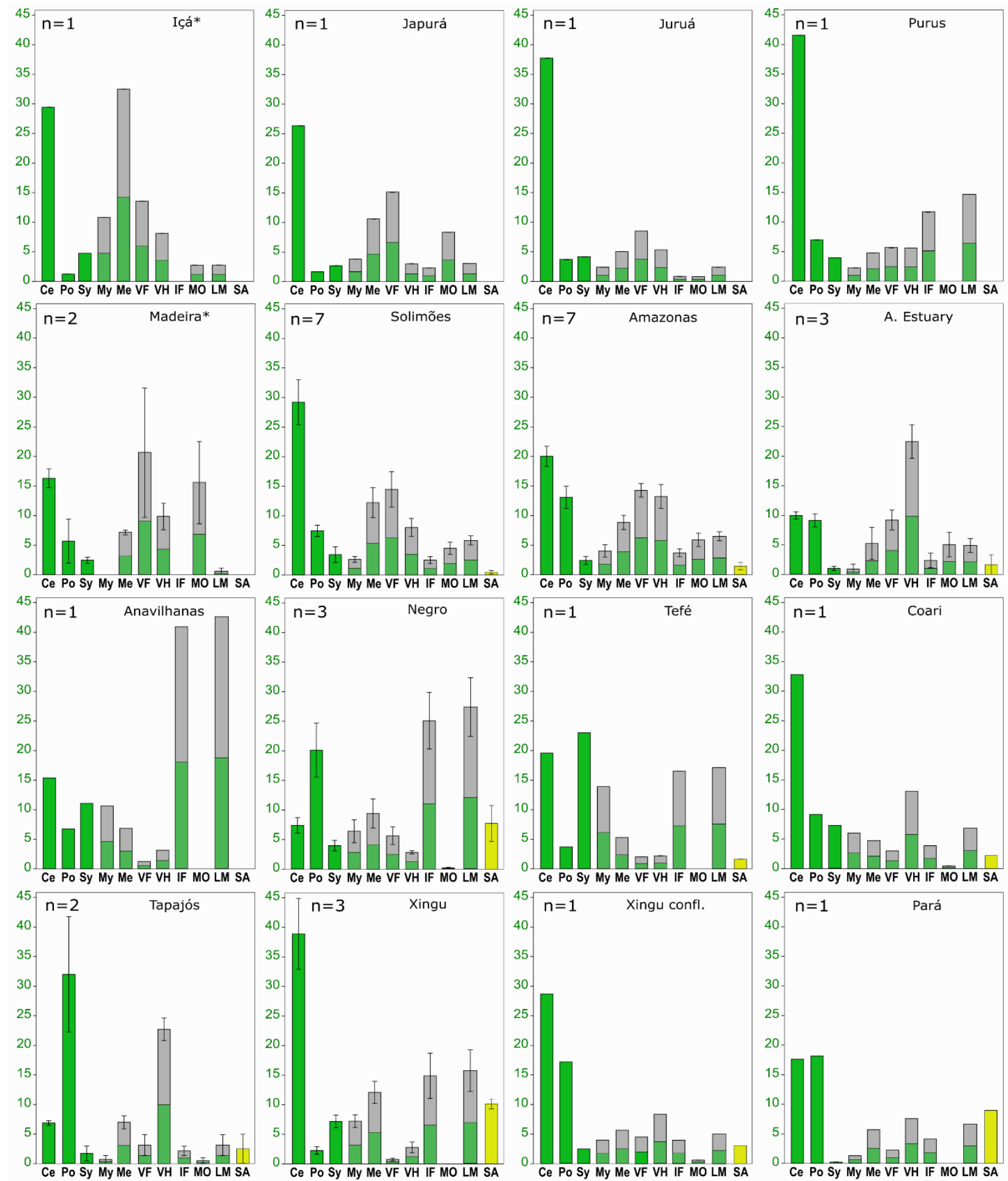

Figure 32 - Pollen percentage graphs. Ce - Cecropia, Po - Poaceae, Sy - Symmeria, My - Myrtaceae, Me - Melastomataceae, VF - Várzea forest, VH - Várzea Herbs, IF - Igapó forest, MO - Montane taxa, LM Late to Mature forest, SA - Savanna taxa (x10 exagerrated), $n$ - number of analyzed samples. *Percentages based on less than 200 pollen grains. 


\section{DISCUSSION}

\subsection{Pollen Source}

The pollen content of riverbed sediments does not reflect the lush biodiversity that constitutes this highly diverse ecosystem. The fact that most of the tropical flora consists of entomophilous plants that have low pollen production and dispersion capacity, favors the dominance of a few wind-pollinated taxa, especially those found along the floodplains. Most taxa are members of genera/families containing species well adapted to a seasonal inundation regime. Several taxa are representative of some stage of successional vegetation that are characteristic of the constant environmental disturbance that shapes the várzea. The overall contribution of flooded vegetation can exceed $80 \%$ of the total assemblage, when Cecropia and Poaceae are included. Composition of the inundated forest vegetation, hence the palynological record of fluvial sediments, are influenced by water-type, acidity, nutrients, humic matter, flooding regime, and geomorphology (Prance, 1979; Junk et al., 1989; Mertes et al., 1995). Terra firme taxa are represented by high diversity, low abundance, and several are represented by single occurrences in the assemblages, e.g. Cenostigma, Copaifera, Symphonia, Dinizia.

The palynology of Solimões-Amazonas River sediments (Figure 39) seems to respond to aspects of the floodplain vegetation (Figure 13) and geomorphology (Figure 9). Along the Amazon River, both upstream and middle reaches are predominantly covered by a dense flooded forest, in contrast, the floodplain of downstream reaches has a flatter topography, lower inundation height, largely covered by lakes and grasslands (Mertes et al., 1995; Hess et al., 2003). Contribution of the sum of várzea herbs and Poaceae show a good correspondence to the canopy opening of the floodplain vegetation especially after the Madeira confluence (Figure 33.1). Conversely, trees contribute with higher percentages at the upper reaches of Solimões and decrease downstream (Figure 33.2). This correspondence supports that the palynological record produced by the drainage system, as fluvial deposits and the Amazon fan sediments, better translates the state of the lowland floodplains than of the terra firme landscape. The seasonal flooding regime that controls vegetation structure along the mainstem is also reflected in the pollen assemblages. 

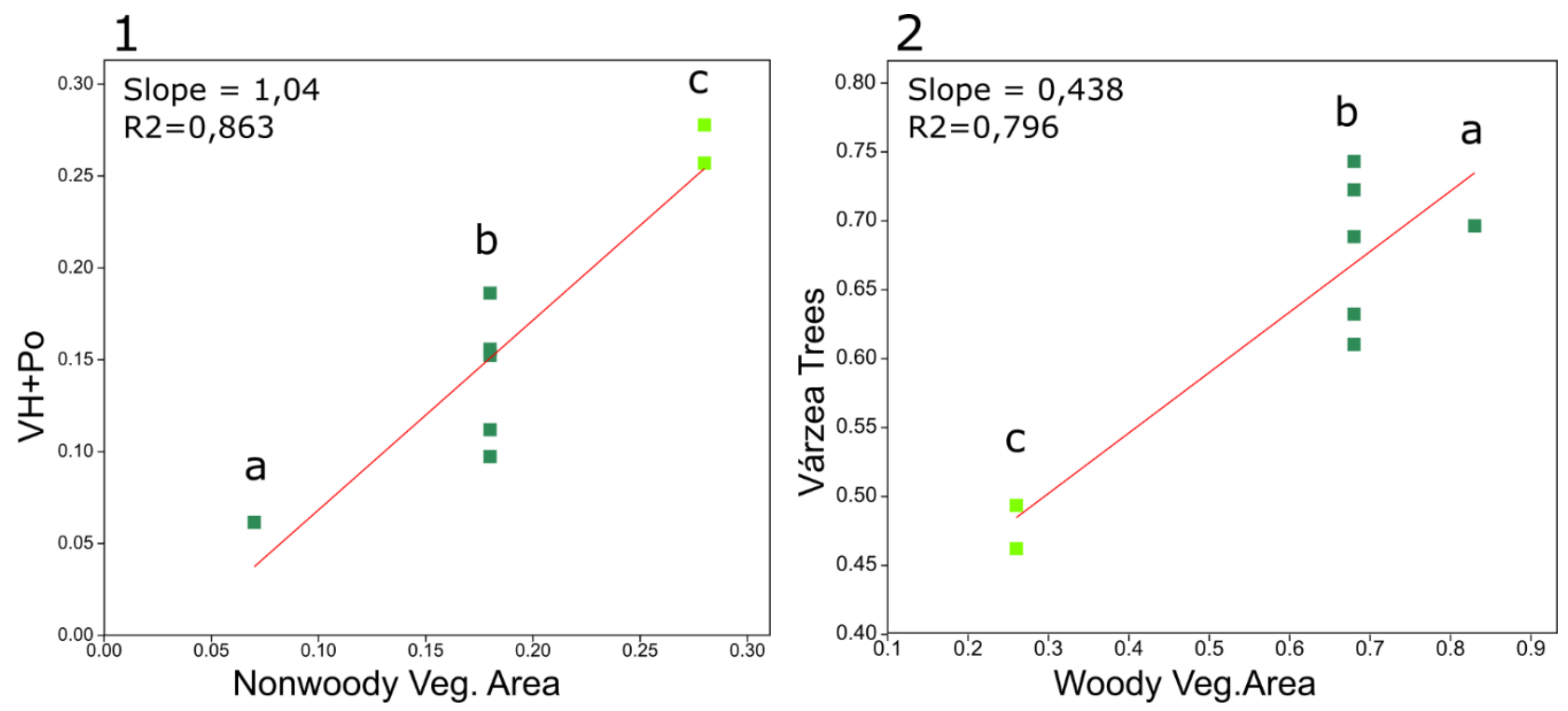

Figure 33 - Percentages of classes of vegetation cover (Hess et al., 2003) versus pollen percentages. The samples for comparison are those inserted in the areas analyzed by Hess et al. (2003), except the samples of the Lower Solimões, which are located immediately downstream of the area. (a) Mamirauá, (b) Manacapuru, (c) Óbidos. 1. Contribution of várzea herbs $(\mathrm{VH})$ and Poaceae (Po) correlate with the floodplain area occupied by nonwoody vegetation. 2. Contribution of várzea trees is related to floodplain woody vegetation cover.

\subsubsection{Trees}

Cecropia is the most common type along the Amazon fluvial system and particularly abundant in the Solimões River and whitewater tributaries, which are likely the main sources of this signature that reaches the Atlantic. It grows in early-successional stages and relates to the disturbance caused by lateral erosion and flooding, occupies a landscape widely covered by scroll-bars and short-lived islands, typical of the western upstream reaches (Figure 37.1) (Salo et al., 1986; Mertes et al., 1995). The overrepresentation of Cecropia pollen in Xingu River sediments can be attributed to fluvial disturbed environments related to the dense set of braided islands upstream of the Xingu ria. Anthropogenic disturbance is also important, as the highest values of Cecropia (52\%) associated with Attalea and Schefflera might characterize the first stages of succession posteriorly the land abandonment after years of land use (Moran et al., 1994) and terra firme areas with a more open forest canopy. This taxon is almost absent in nutrient-poor blackwater floodplains (Parolin, 2002), the representativeness in considerable 
percentages on these environments $(5-17 \%)$ is explained by the high pollen productivity and dispersal capacity (Bush and Rivera, 1998; Gosling et al., 2009).

Alchornea pollen is constant in fluvial sediments of the lowlands, though no eastwest trend is observed in its contribution, probably because this genus occurs in several distinct environments and is widely distributed in Amazonia. The shrub A. castaneifolia is an early colonizer in river bars (Kalliola et al., 1991), A. discolor is a common tree of igapó forests (Scudeller and Vegas-Vilarrúbia, 2018), and A. triplinervea occupies high-várzea and terra firme (Campbell et al., 1992).

Iriartea and Mauritia pollen are common constituents of várzea assemblages; these palms are widely distributed in the western lowlands, associated with elevated precipitation and/or wetlands, and at the Eastern Amazon, occur preferentially at stream margins (Henderson, 1990; Vormisto et al., 2004). Pseudobombax and Luehea, accompanied by other taxa from the LM group represent a transition to late-secondary or climax forests (Worbes et al., 1992), and are frequent types in Amazon River sediments.

Abundance of Symmeria, associated with Myrtaceae (possibly Eugenia?) and a late-successional to mature (LM) vegetation make up a characteristic signature of igapó forest, abundant in floodplain lakes (Sá et al., 2016) and clear- and black-water rivers. Symmeria is adapted to long periods of flooding and grows over finer substrates, common in early-stages of succession in floodplain-lakes and igapó (Wittmann et al., 2011), thus can be used as indicator of low energy flooded environments. Primary plant succession in environments of low sedimentation may take decades, as shrubs, and small trees that colonize igapó floodplains have comparatively slow growth rates (Figure 15) (Wittmann and Householder, 2017). Differently from modern pollen data by Bush (1991), Symmeria appears as an important taxa in igapó assemblage, even more abundant than in the várzea.

Savannah (SA) source is minor and pollen from taxa attributed to this ecosystem do not exceed $1.1 \%$. The Xingu and Pará rivers exhibit the highest values of SA (Figure 32 ), which indicate a source from the ecotone zones and cerrado in the southern and southeastern edges of the Amazon Basin, while elevated values of SA in Negro River suggest a contribution from the lavrado via Branco River and from the campinaranas at the Negro headwaters. 
Contribution from montane sources reaches the lowlands through fluvial transport, and ultimately the ocean (Muller, 1959; Hoorn et al., 2017). MO group is practically absent in black- and clear-water rivers and scores the highest values in whitewater tributaries. In the Amazon mainstem, MO mean contribution usually represents $<3 \%$, and contrary to expected (Haberle, 1997), do not show an apparent decreasing trend with increasing distance from the Andes. Hedyosmum percentages are highly variable and suggest different inputs of montane taxa along the river course through tributaries. Here is important to highlight that taxa such as Hedyosmum, Podocarpus, Ilex, and Panopsis commonly used as montane indicators can also occur in warmer lowlands on appropriate habitat types, especially highly flooded wetlands (Householder et al., 2015). This suggests that contribution from montane taxa might be overestimated to some extent. The absence of Alnus in Purus and Juruá rivers evidence the isolation of these tributaries from the Andes (Latrubesse et al., 2010), though still receive a contribution from elevated areas e.g. Hedyosmum, Podocarpus.

\subsubsection{Herbs}

Interpretation of the pollen record based on Poaceae is quite problematic due to its occurrence in a wide range of environments and pollen analysis's inability to recognize an accurate taxonomic level based on the grain morphology. Many implications arise from the understanding of its source, once pronounced variations on grass pollen recognized along the record translate important paleoenvironmental changes. A series of hypothesis were raised for the origin of Poaceae grains that reach the Amazon Fan deposits, such as floating meadows and grasslands in the lower reaches of the Amazon River, lowland savannas, Andean grasslands, and from tributaries draining the Central-Brazilian cerrado (Haberle, 1997; Hoorn et al., 2017). Poaceae contribution scores the highest values at Lower Negro, Tapajós, Pará, and Amazonas Rivers, and the probable sources in each river are discussed below.

Poaceae values along the Amazon River correlates with VH (Figure 34) and the opening of the floodplain forest cover (Figure 33). An increase of overall herbs distinctly occurs near Óbidos, where the topography is flatter, and hundreds of patchy floodplain lakes and open vegetated fields spreads over the floodplain. The substantial increase in 
Poaceae just after Negro River confluence suggests an influence of this tributary in this stretch.

Poaceae values of Solimões and Madeira 5-13\% rivers are higher than in Purus, Juruá, Japurá, and Içá, which suggests some possible sources: (1) open Andean grasslands might contribute with Poaceae input in Solimões and Madeira rivers, indicated by lower values of herbs in Purus and Juruá, which are isolated from the Andes. (2) Grass pollen in Madeira River can come from the Beni savannas (Llanos de Moxos) in its headwaters, in northern Bolivia, indicated by the presence Gomphrena. (3) A contribution from the herbs that grow on the landforms of the várzeas.

Madeira River has a narrower floodplain than Solimões, much similar to those of Içá and Japurá rivers that show low grass pollen production. This suggests that the Beni savanna or Andean grasslands at Madeira headwaters may contribute with an important share in Poaceae pollen in this tributary. A main high Andean contribution would be expected to show a decreasing pattern with an increasing distance from its source, however, the opposite is observed along the Amazon River. The distinct increase in Poaceae and other herbs at the middle and lower reaches point to a major várzea production of this signature and that contribution of herbs from the Open Andean vegetation, over $2500 \mathrm{~m}$ altitude, is minor at the lowlands.

In blackwater rivers, the nutrient-poor water hinders the growing of floating meadows and the floodplain stability reduces the presence of pioneer colonialists (Kalliola et al., 1991), then is unlikely that dominance of Poaceae in the lower Negro River is localsourced. Negro River watershed covers open areas of campinaranas (Figure 28) and the catchment area of the Branco River, one of its biggest tributaries, encompasses the Roraima/Rupununi Savannah ("lavrado"), which are probably the origin of the observed Poaceae rich signature in Lower Negro River, indicated by the presence of savannah elements (SA) and low VH. In the open vegetation of the Guyana, Wijmstra \& Van der Hammen (1966) reported a palynological association characterized by an overrepresentation of Poaceae and occurrence of Byrsonima and Mauritia. Results of $\delta^{13} \mathrm{C}$ for total organic content by Sun et al. (2017) and specific compound by Häggi et al. (2016) for Lower Negro River point to a predominantly C3 vegetation contribution, by respective values of -26.5 to -29.8 , and -35.9 to -34.7 . The palynological signature also 
shows a predominant forest source, nevertheless it captures an increase in Poaceae in consortium with savannah elements (campinaranas and lavrado). An influx of Solimões flooding waters via Furo do Ariaú may as well contribute (Figure 26), though low values of Cecropia suggest this influence is minor or absent in the studied sites.

The Tapajós River sediments presents the highest values of Poaceae and $\mathrm{VH}$, albeit has a narrow forested floodplain edged by a closed terra firme vegetation. Possible sources are contemplated and briefly discussed: (1) Anthropogenic impact - open vegetated and deforested areas at the headwaters: analogously, the extensive pastures that intersect Xingu River do not cause an expressive increase in the contribution of herbs, thus a similar scenario over $100 \mathrm{~km}$ upstream would be unlikely to cause such rise. (2) Local source - pioneer herbs that grow on exposed lands during low water level: sediments are seasonally exposed (Irion et al., 2010) and colonized by perennial herbs. An example is the fluvial archipelago at the upper $\sim 15 \mathrm{~km}$ stretches of the ria, which are unstable (Archer, 2005) and are the nearest upstream floodplain grasslands. (3) External source - Amazon River sediments are constantly deposited upwards by a backflow effect: Amazon River sediments reach the lower $40 \mathrm{~km}$ of the Tapajós ria (Fricke et al., 2017), a small fraction of very fine particles may reach further distances.

In the Tapajós ria sediments, contribution of Poaceae is higher and Cecropia is lower than the values found in the Amazon River, and Asteraceae is almost exclusively represented by the Ambrosia-type, differently from the main stem sediments. These features of the pollen signature indicate that a local source (2) dominate, though an minor input from Amazonas River (3) would explain the presence in low quantities of Iriartea, Acalypha, Alternanthera, Ilex, and Podocarpus, which are more commonly found in the Amazon River sediments, though not exclusively.

At South of the Marajó Island, the Pará River is formed by the confluence of Tocantins River with a branch of the Amazonas River and other minor tributaries. Poaceae and SA values in this site are higher than in Amazon Estuary and VH less important, thus suggesting that drier environments at southeastern region of the Amazon Basin are the main source of Poaceae to riverine sediments. 


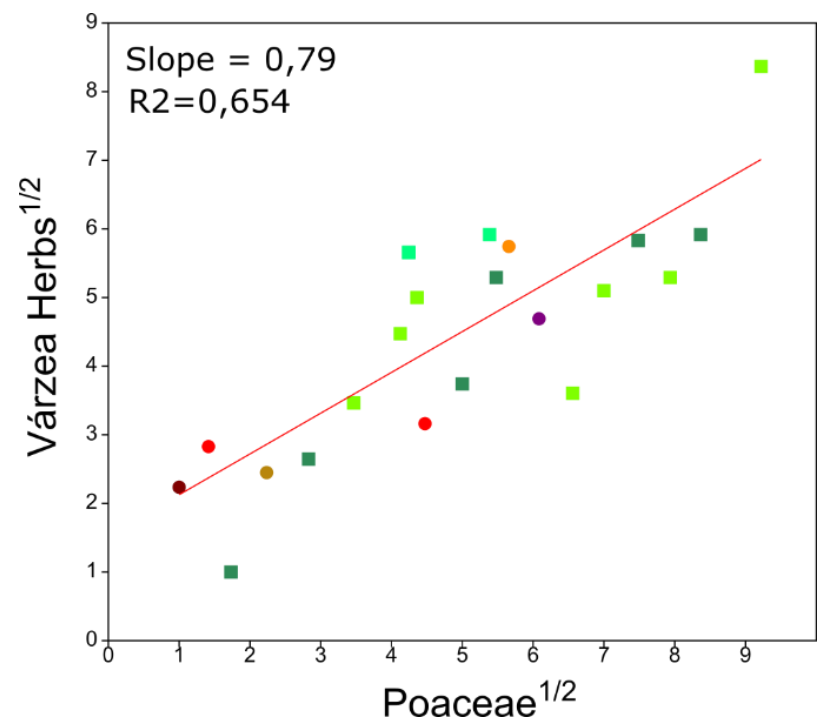

Figure 34 - Correlation of square-root counting values of Poaceae versus Várzea herbs, Lower Negro and Pará rivers samples are removed. Solimões (darkgreen), Amazonas (lightgreen), Amazon estuary (lightgreen squares), Negro (black), Xingu (cyano), Madeira (red), Tapajós (blue), Coari (purple), Tefé (gray), Purus (pink), Juruá (orange), Japurá (dark brown), Içá (light brown).

\subsection{Palynological assemblages}

Ternary diagram based on IF, VF, and VH permits distinguish forests of várzea from igapó (Figure 35), while the diagram based on LM, VH, and Cecropia indicates the successional stage of the contributing vegetation and permits infer about aspects of floodplain dynamics (Figure 36Figure 37).

The signature of várzea vegetation, characterized by early to late-successional forest and pioneer herbs, is pronounced at the Solimões, Amazonas, Içá, Japurá, Juruá, and Madeira rivers. Early-successional vegetation (Cecropia) and pioneer herbs (Poaceae, Asteraceae) are common in the whitewater rivers, where newly formed areas are frequent (Salo et al., 1986; Kalliola et al., 1991) and erosion of the landforms along the main channels constantly destroy forest communities (Junk, 1989).

From a core collected in an oxbow lake in southwestern Amazonia, RodríguezZorro et al. (2015) report dominance of Cecropia pollen (15-50\%) and low contribution from herbs, which was attributed to the Acre River fluvial dynamics. This assemblage is similar to the modern meandering whitewater tributary signatures (i.e. Juruá, Purus), except for a distinctly higher Moraceae contribution that might reflect a bigger local influence from terra firme. 
In Tapajós River, high amounts of pollen from herbs (Poaceae, Ambrosia) overlap the signal from the adjacent forest and set these samples closer to the $\mathrm{VH}$ vertex on the ternary diagrams. The contrast of the palynological signature with the surrounding vegetation, an igapó margined by a closed terra firme forest, indicates that the ria sediments reflect aspects of part of the floodplain instead of terra firme, as previously discussed.

Negro, Tefé, and Xingu rivers exhibit elevated values of IF and LM, which characterize and older and stable vegetation, reflecting less intense hydro-geomorphic processes. Floodplains from black and clearwater rivers tend to be narrower and more stable, with low suspended sediments, deposition and erosion rates, that favor a longer development of the forest and impair the growth of early herbs and floating meadows (Kalliola et al., 1991; Montero and Latrubesse, 2013; Wittmann and Householder, 2017). Xingu River exhibit contribution from advanced stages of successional vegetation and dominance of Cecropia, which suggests a source from the stable margins and another from disturbed mid-bars and deforested lands.

The intermediate composition of igapó and várzea signatures in Purus River is attributed to a input from several blackwater streams and a straightening of the channel in the lower stretches that may reduce the lateral erosive disturbance. The right bank of Purus River is formed by an older paleo-várzea than those margining other western tributaries i.e. Juruá River (Irion et al., 2010) that might host a more mature vegetation.

The Coari River shows a mixture of igapó and várzea forest signatures due to an input from the Solimões River, pointed by sediments with low mineralogical maturity and high amounts of Cecropia with the presence of Hedyosmum, Iriartea, Acalypha, and Alternanthera. At an upstream stretch of Coari-lake, Horbe et al. (2011) found higher values of Symmeria, Alchornea, and Amanoa and low values of Cecropia, which indicate minor influence of Solimões and better corresponds to an igapó forest signature. Similarly to Lago Calado (Behling et al., 2001), Solimões River input of inorganic sediments in Coari is much more expressive than the palynological input, due to high amounts of suspended solids and low organic content transported by the main channel (Moreira-Turcq et al., 2003). 


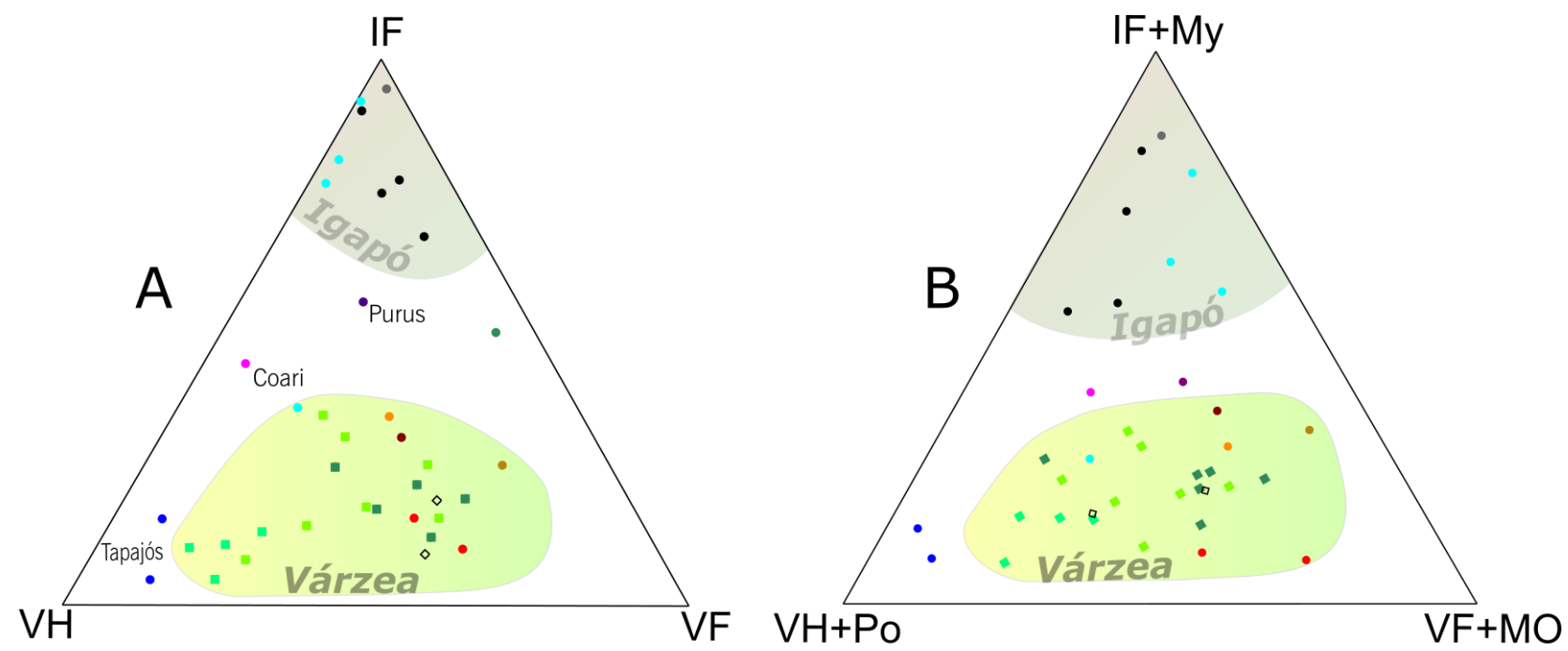

Figure 35 - Ternary diagrams A. based on IF (igapó forest), VF (várzea forest), and VH (várzea herbs). B. based on IF+My (Myrtaceae), VH+Po (Poaceae), VF+MO (Montane taxa). Igapó vegetation are poor in herbs and whitewater várzea elements, this group includes Tefé, Negro, and Xingu. Várzea vegetation includes Solimões, Amazonas, Amazon estuary, Japurá, Juruá, and Içá, note a increase of herbs to the east. Hollow diamonds are based on botanical affinity of two samples from D'Apolito et al., (2018), collected from a core near Manaus and attributed to Pliocene-Pleistocene age.

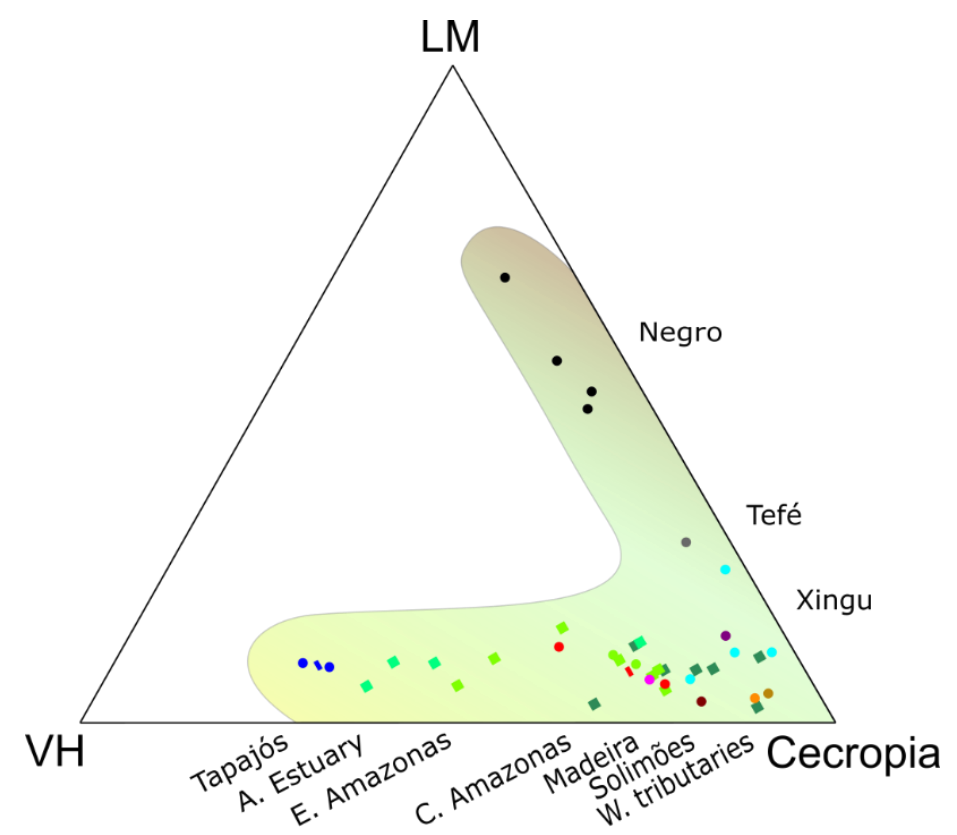

Figure 36 - Ternary diagram of late to mature successional forest (LM), Cecropia, and várzea herbs (VH). Solimões (darkgreen), Amazonas (lightgreen), Amazon estuary (lightgreen squares), Negro (black), Xingu (cyano), Madeira (red), Tapajós (blue), Coari (purple), Tefé (gray), Purus (pink), Juruá (orange), Japurá (dark brown), Içá (light brown). 


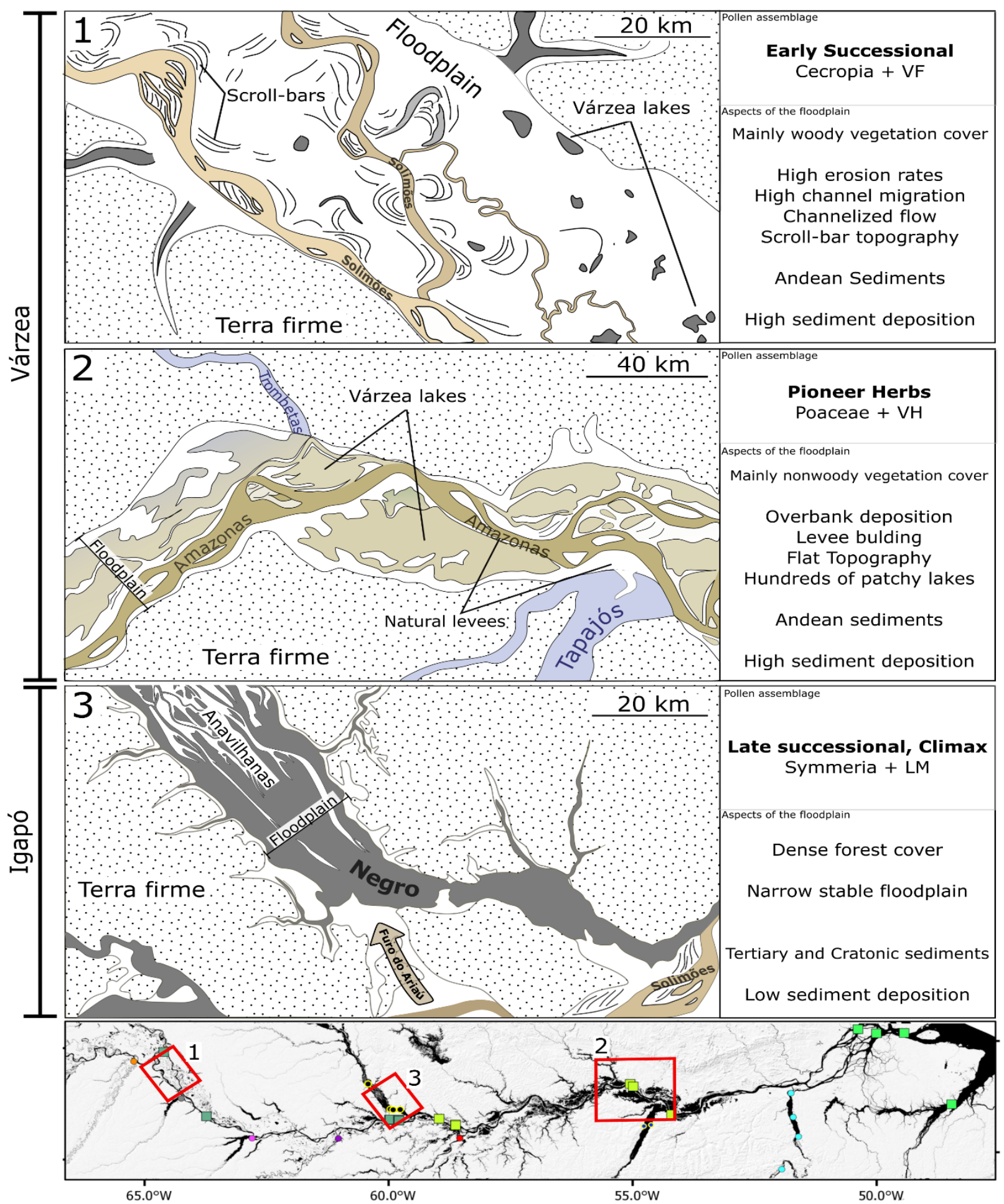

Figure 37 - Schematic floodplain geomorphologic features in three areas of the basin. Charactistic palynological signal and aspects of the floodplain listed aside. 1. Upper reaches of Solimões River, 2. Middle reaches of Amazonas River, Óbidos region. 3. Lower Negro River, Manaus region. Floodplain aspects based on Mertes et al. (1995, 1996) and Hess et al. (2003). 


\subsection{Detrended Correspondence Analysis (DCA)}

DCA axes represent hypothetical environmental gradients expressed in standard deviations of species turnover (SD units x100) that explain variance based on taxa occurrence and abundance. Ordination of pollen percentage data of Amazon Basin samples promotes a separation of tributaries and shows a transitional change of the Solimões and Amazonas rivers palynological signatures (Figure 38). DCA distribution of data is driven by changes in the floodplain vegetation aspect. Eigenvalues representing the first and second axes explain $77 \%$ of the variance within the pollen data matrix. The descending SD units in Axis 1 correspond to a downstream direction and relate to a transition from the dominance of trees to a rising herbs contribution (Figure 33), respectively represented at each extreme by Xingu and Tapajós rivers. Solimões and Amazonas rivers show a progressive change in the pollen signature, which suggest that the Solimões River is the main contributor and its signature gradually changes downstream the course of Amazon River by the floodplain vegetation and input from other tributaries. Negro River exhibits a similar gradient of the Amazon main stem; notwithstanding, the increase of Poaceae at the downstream samples cannot be directly correlated with the surrounding landscape nor with the floodplain vegetation. This pattern instead reflects a transported component from the Negro and Branco rivers headwaters, largely occupied by campinaranas and savannahs. Rising of SD units on the Axis 2 is driven by a decrease of Cecropia and várzea herbs and increase of Moraceae, Myrtaceae, Symmeria, Pouteria, and Sapium. This gradient corresponds to a shift from earlysuccessional and pioneer vegetation to late-successional to mature forests. 

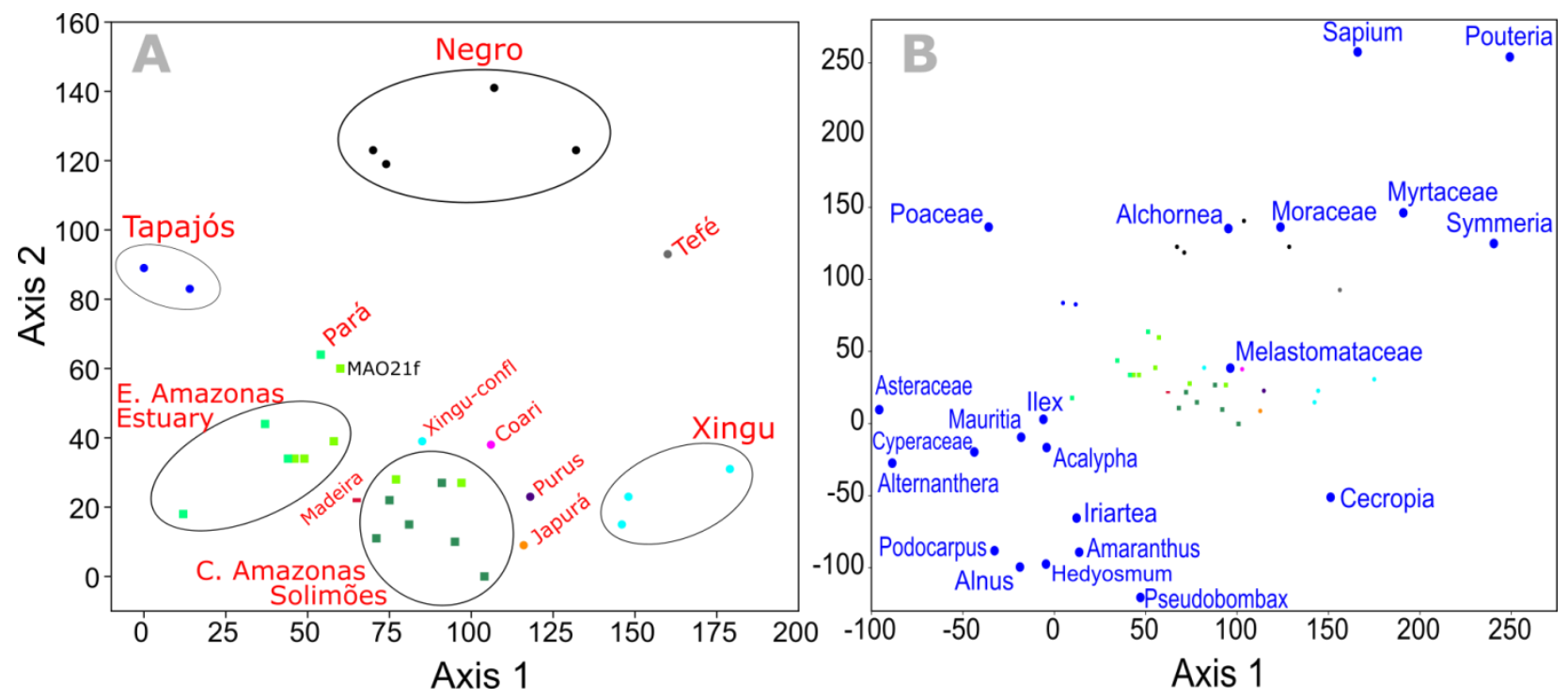

Figure 38 - Results of DCA ordination of modern pollen data, in percentage, from the Amazon Basin. Excluded samples from Içá and Japurá. A. All pollen included allows separate tributaries. Eigenvalue of DCA, Axis 1-0,179, Axis 2-0,131. B. Some of main pollen that yield the samples separation. E. Amazonas encompasses the samples near Óbidos, C. Amazonas encompasses the samples just after Negro River confluence.

\subsection{Influence of Major Tributaries}

The hindmost palynological signal that reaches the estuary region is gathered all along the drainage basin system, since over $3500 \mathrm{~km}$ upstream. Whitewater tributaries and Solimões River carry a pollen load rich in Cecropia, together with an important VF and MO contents. Smaller blackwater tributaries such as Tefé and Coari, do not represent a considerable input to the main stem, contrarily, they trap material transported from the Solimões River, as shown for Coari.

After Negro River confluence and before Madeira, a well-marked increase in Poaceae and IF is detectable in the samples located in the first $110 \mathrm{~km}$ downstream. A peak in pollen types that characterize the Negro River signature evidences this input and contrasts with a decrease in the contribution of Cecropia and Melastomataceae/Combretaceae, which are characteristic of Solimões River. Pollen of IF turn less important in the overall assemblage in the middle and lower reaches of Amazonas River and suggest that this source either rapidly becomes diluted in the main load, deposited or degraded along the way. The high amount of floodplain-lakes downstream Negro River may act as sinks for sediments and organic matter (Moreira- 
Turcq et al., 2004) and contribute with the progressive reduction in the influence of distant sources. The pronounced separation of samples from Negro and Amazonas rivers in the DCA (Figure 38) and a gradual change of the palynological assemblage of Solimões to Amazonas River, indicate that Solimões is the greatest contributor. The middle and lower reaches of the Amazon River strongly affects the end signal by a distinct input of herbaceous pollen from the adjacent várzea.

The Madeira River influence was not recognized in the pollen signature downstream of its confluence. This might relate to the fact that Madeira River is responsible for a low contribution of organic matter, contrary to the great input of suspended sediments (Moreira-turcq et al., 2003), which probably results in the increase of acritarchs observed in the middle Amazonas River. These fossils are transported with the suspended solids and trace from the eroded Paleozoic rocks outcropping in the Andean regions.

The Tapajós and Xingu Rivers do not have a significant influence in the pollen composition of the Amazon River. The contribution of the mentioned tributaries would be expected to cause a rise in Poaceae and Cecropia, respectively, which is not seen downstream. Reversely, a load from the Amazonas River is deposited in the lower reaches of the ria, and indeed, this lake-like physiography acts as traps rather than a source of sediments (Fricke et al., 2017) and organic matter (Bertassoli et al., 2017). At the Xingu-confluence, the palynological assemblage differs from the upstream tributary signature. Higher values of Poaceae and Cyperaceae together with Ilex, Ericaceae, Alternanthera and Acalypha, evidence an Amazon River influx by a backflow effect (Fricke et al., 2017). This Amazon River input at the lower reaches of Xingu ria has already been described by Häggi et al. (2016) through leaf-wax biomarkers and Fe/K ratio.

Pará River has a distinct geochemical and palynological signature from the Amazon estuary, exhibits a higher contribution of Cecropia, Poaceae, and SA, and lower of VH and VF, which indicates that Tocantins River is more influent than Amazonas River at the South Marajó Island branch. Diversity of taxa from the cerrado suggests a predominance of Tocantins River contribution and corroborates with compound-specific $\delta^{13} \mathrm{C}$ and $\delta \mathrm{D}$ data published by Häggi et al. (2016). 


\subsection{Comparison between the suspended and riverbed load}

The content of riverbed sediments are compared to the suspended load data published by Haberle (1997) and Haberle and Maslin (1999) (Figure 39). Haberle does not explicit the period when the suspended samples were collected, therefore, seasonal aspects could not be approached. The suspended load is susceptible to temporal variation such as blooming and flooding periods, while continuous fluvial deposits tend to integrate this variability (Chmura and Liu, 1990; Smirnov et al., 1996; Brown et al., 2007). Physical parameters of the pollen grains and hydrodynamics of transport can also affect the composition and abundances of the pollen load (Brush and Brush, 1972; Smirnov et al., 1996). Despite these aspects, the pollen assemblages of the analysed riverbed samples and the suspended load (Haberle, 1997; Haberle and Maslin, 1999) are mostly consistent.

Cecropia and Melastomataceae/Combretaceae show the same downstream decreasing trend in the bed and suspended load, which corroborates that these taxa relate mainly to the western Amazon floodplain environments. The suspended load is richer in Cecropia, Moraceae, and Iriartea pollen, the first two by nearly double the contribution, probably due to the easiness of transport or maybe a blooming period during the sampling of the suspended sediments. Contribution of Alchornea, Asteraceae, Cyperaceae, and Mauritia are higher in riverbed sediments. Myrtaceae, Melastomataceae/Combretaceae, Poaceae, Acalypha, Ilex, Hedyosmum, Schefflera, and Alnus exhibit conformable values between the bed and suspended sediments. These observations are indicative of differential behaviour of pollen grains such as noted in other studies (Brush and Brush, 1972; Catto, 1985), though a seasonal effect on the suspended sediments cannot be discarded. Catto (1985) observed that Cyperaceae is preferentially concentrated in coarser sediments while Poaceae and Alnus are preferentially associated with finer sediments, which correspond to the pattern of higher abundance of the former taxa in the bed and of the latter two in the suspended load. In general, the pollen deposited along the channel is representative of the content transported in suspension to the ocean. Continuous marine deposits probably integrate seasonal variations; however, effects of differential deposition must be taken into account when comparing continental and marine deposits, though this issue requires more investigations. 


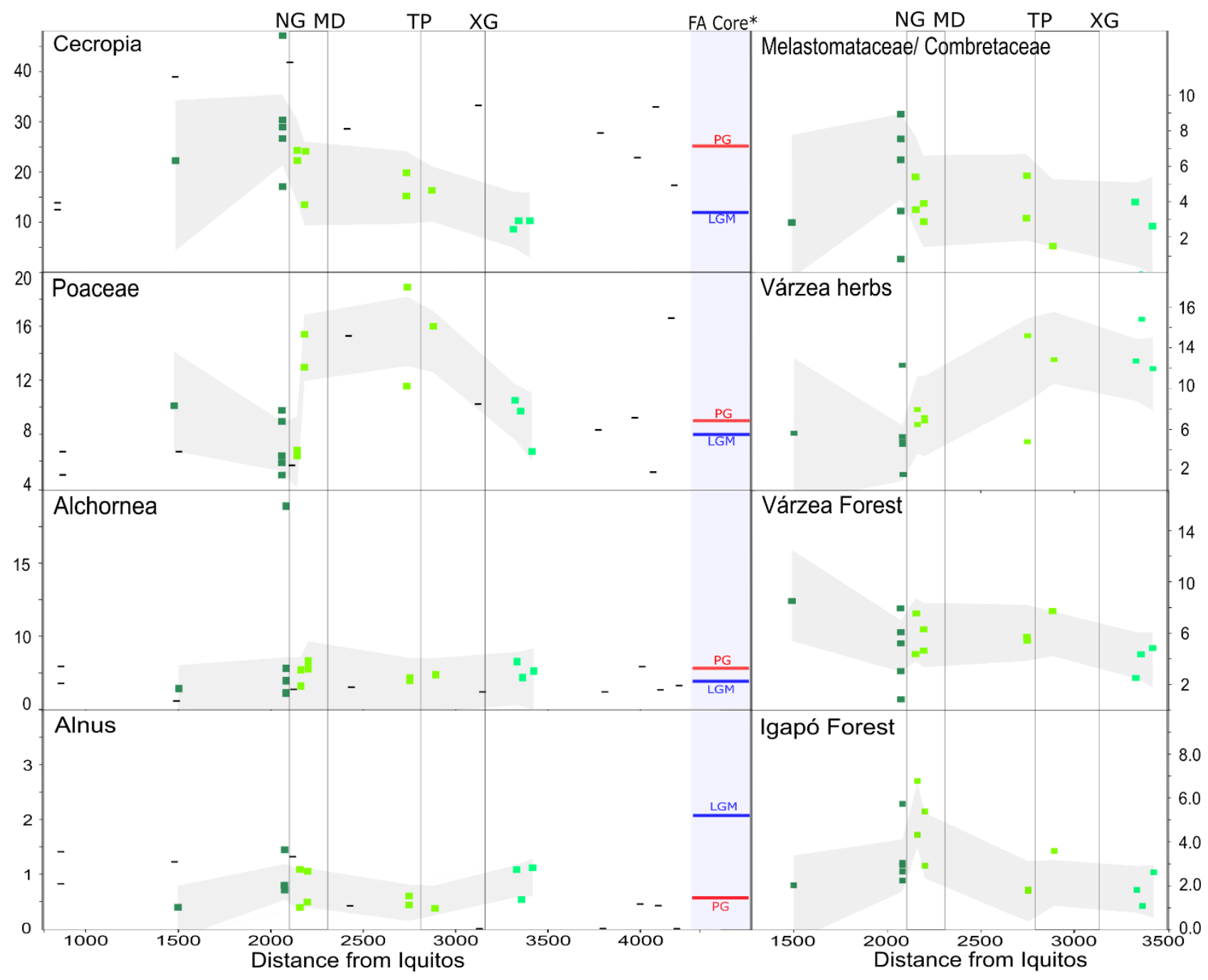

Figure 39 - Percentage values of types and groups along the Amazon River, distance measured from Iquitos, Peru. Analyzed riverbed sediments (present study) are represented by squares. Palynological data from Haberle (1997) of suspended sediments are plotted by dashs, and of a core in the Foz do Amazonas* represented in the blue columm, for the Last Glacial Maximum (LGM) and Postglacial (PG). Confluence of major tributaries are marked, NG = Negro; MD = Madeira; TP = Tapajós; XG = Xingu. Grey band: 95\% confidence band calculated by LOESS, with smoothing factor of 0,5 . 


\subsection{Implications to Pollen Record}

Some palynological records are evaluated based upon the perspective of floodplains as the major source of pollen and geomorphological aspects driving vegetation and palynological changes along the gradient.

Comparison with upper Quaternary record of the Foz do Amazonas Basin of Haberle (1997) and Haberle and Maslin (1999): DCA exhibits a similarity of the samples of the Amazon Fan and those of riverbed sediments of the lowlands (Figure 40). Low contribution of Cecropia in the Foz do Amazonas sediments during the Last Glacial Maximum (LGM) is probably related to slower channel migration and lower lateral erosion rates in the Western Amazon. The relative stability of Poaceae, Cyperaceae, Asteraceae, Alternanthera, and Acalypha, throughout the record suggests that várzea grasslands remained on the landscape. A slight increase of Poaceae and taxa associated with dry environments and a small decrease in some várzea herbs during the LGM might indicate some expansion of drier vegetation, though not expressive basin-wide, and shrinking of floodplain-lakes caused by a incised channel and higher riverbanks. Increase in Symmeria in postglacial periods might indicate forming of rias and that floodplain-lakes increased in the landscape or a bigger connection with the main channel by more wide-ranging floods due to a decrease in the slope of the Amazon River after the glacial period (Irion et al., 2010). The palynological assemblage of Pará River suggests that the cerrado contributes with an important input of grass pollen, thus an expressive increase in Poaceae would be expected if large areas of savanna dominated basin-wide during glacial times. Montane taxa represent $<3 \%$ of the modern pollen assemblage at the lower ends of Amazon River, so the rising to over $10 \%$ in the LGM suggests a substantial expansion of these taxa to the western lowlands. These interpretations agree with the scenario discussed by the authors. 


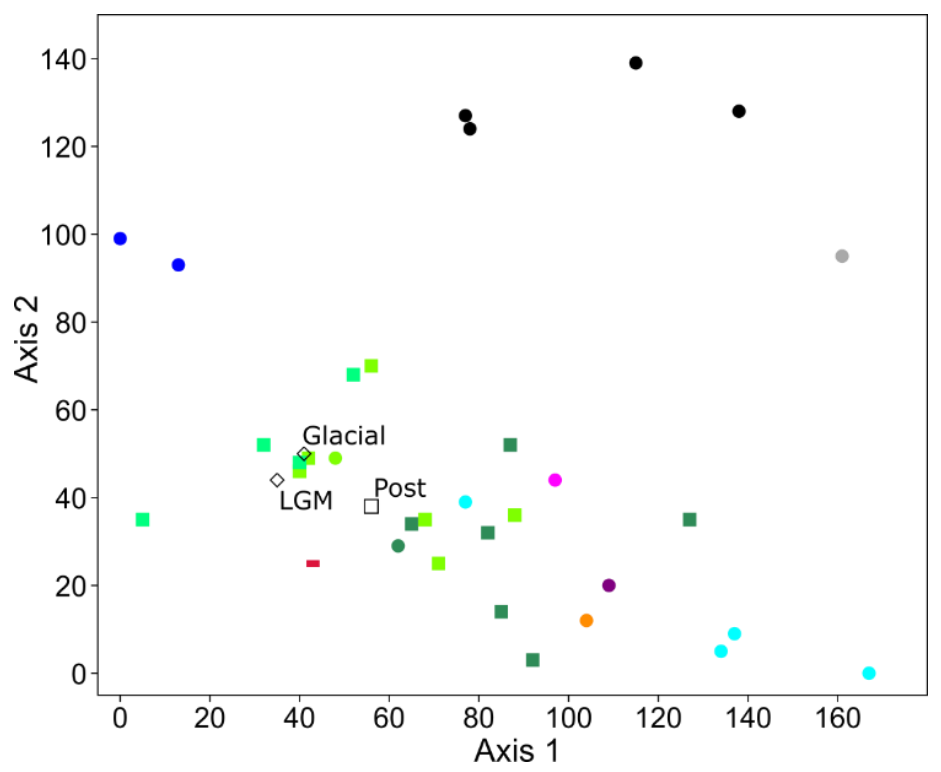

Figure 40 - DCA of modern pollen data (this study) and Foz do Amazonas data from Haberle (1997) in three moments: Pleniglacial, Last Glacial Maximum (LGM), and Postglacial (PG). During the glacial period contribution of Cecropia reduces and of herbs increase, which suggests a slight expansion of open vegetation and reduction of river erosive migration. Solimões (darkgreen squares), Amazonas (lightgreen squares), Amazon estuary (lightgreen squares), Negro (black), Xingu (cyano), Madeira (red dash), Tapajós (blue), Coari (purple), Tefé (gray), Purus (pink), Juruá (orange).

Hoorn et al. (2017) describe the Neogene scenario of evolution and establishment of the Amazon River and vegetation cover after a core from Foz do Amazonas Basin. Although the record extends from the late Oligocene to the Pleistocene, and the older the record, the more difficult is to make an analogy from a modern data, this study bring insights into the interpretation of the Amazon Fan record. Hoorn et al. (2017) discuss the possible sources and causes for the rise in Poaceae pollen that started at the Middle Miocene and higher increases registered after $\sim 9 \mathrm{Ma}$ and $\sim 4 \mathrm{Ma}$. According to the authors, it is unlikely that the lower reaches would have been the main cause of the rise of grasses since the proto-Amazon River already drained these areas. They argue that lowland savannas and highland grasses cover an extensive part of the drainage basin thus should have the large share in the pollen contribution. The concomitant increase of Poaceae, taxa of the freshwater community (e.g. Cyperaceae), cerrado and savanna taxa (e.g. Alternanthera), Asteraceae, and montane taxa, are related to the onset of a transcontinental river and increase savannas around $9 \mathrm{Ma}$ and at $4 \mathrm{Ma}$ to the expansion 
of the cerrados, additionally to a growing contribution from the Andean grasslands (Páramos and Punas) and newly formed megafans in the foothills.

This study shows that the western tributaries poorly contribute with herbs to the main Amazon load, which suggests that the Poaceae input from the open Andean vegetation achieve minor contribution at the lowlands, thus this source do not explain such a distinguishable increase in grass pollen. As indicated by the Pará River, a large expansion of cerrado could potentially cause an increase in grass pollen, though it should be noted that Alternanthera, the main taxa of the 'cerrado and savanna' group of Hoorn et al. (2017) relates more to the seasonally flooded (várzea) savannahs (Kalliola et al., 1991; Junk and Piedade, 1993). Currently, the main contribution of Poaceae and other herbs come from the middle and lower reaches of the Amazon River, where open vegetation occupies larger areas of the floodplain. This suggests that the Amazon Fan record reflects mainly changes in the landscape of the floodplains rather than on the terra firme, and that, despite the open vegetation of várzea occupies a relatively small area of the overall drainage basin, they represent the largest share in grass pollen.

It is beyond the scope of this study to discuss how and when the Western-Eastern connection of a transcontinental Amazon River takes place. However, the increase in Poaceae in the Amazon Fan deposits can be interpreted as result of a lowland landscape adequate for the establishment of grasslands, associated with floodplains subjected to seasonally long inundation periods (Junk, 1989; Martinez and Le Toan, 2007). Therefore, the Miocene increase of grass pollen possibly relate to a development or connection with wide floodplains covered by lakes and grasslands. A suitable scenario could be the western lowlands of the Neogene Amazon Basin, either with megafan systems (Latrubesse et al., 2010) or mega-wetlands (Albert et al., 2018) and the posterior increase of Poaceae (4 Ma) could relate to an expansion of várzea or a growing connection of the western wet-lands and a reorganization of the basin (Albert et al., 2018). The appearance of Cecropia $\sim 5.4$ Ma may indicate an increase in the rivers erosive activity or a connection with the western avulsive systems, although lower than Quaternary rates, which also coincides with the time of increasing sedimentation rates in the Amazon Fan (Figueiredo et al., 2009; Hoorn et al., 2017). 
Soares et al. (2017) studied a thin sediment layer through drill holes in the lower course of Negro River channel. This layer consists of brownish-gray sandstones cemented by siderite and with subordinate mudstone and conglomerate beds, separated by unconformities from the underlain Miocene strata and the overlain Quaternary Negro River deposits. The palynological content, detailed in D'Apolito et al. (2018), is rich in herbs e.g. Monoporopollenites annulatus (Poaceae), Echitricolporites sp. (Asteraceae); várzea forest taxa e.g. Mauritiidites franciscoi (Mauritia-type), Ilexpollenites tropicalis (Ilextype), Clavamonocolpites lorentei (Iriartea-type), Bombacacidites ciriloensis (Pseudobombax-type); montane taxa e.g. Alnipollenites verus (Alnus-type), Clavainaperturites microclavatus (Hedyosmum-type); and spores. Taxa abundant in igapó forests are less common e.g. Psilatricolporites labitatus (Burseraceae), Retitrescolporites? irregularis (Amanoa-type), Ladakhipollenites? Lolongatus (Symmeriatype). The authors propose an age for the deposits that ranges from late Pliocene to early Pleistocene, $\sim 3.6$ to $\sim 1.9 \mathrm{Ma}$, based on the first appearance datum of $A$. verus and the last appearance datum of $G$. magnaclavata and Paleosantalaceaepites cingulatus. They interpret these sediments as phytostabilized fluvial bars deposited in a channel connected with Andean headwaters during Plio-Pleistocene times.

Comparing the Soares et al. (2017) data with results of this study, it is possible to observe a similarity between the palynological composition of that record and those of the modern riverbed sediments of Solimões (Figure 35). Present data corroborate with Soares et al.' (2017) interpretation of fluvial bars deposited in an ancient course of Solimões River before the megacapture of the Negro River (Almeida-Filho and Miranda, 2007). The contribution of $A$. verus in the sediment strata are much higher, up to $3-13 \%$, than the present values of Alnus in the lowlands, usually $<3 \%$, which suggests that these sediments were deposited under colder periods, such as during the Pleistocene. Punctual occurrences of reworked pollen grains from Neogene units in the modern riverbed sediments call for caution in age determinations based on single grains of index fossil species. Palynological zonation of Soares et al. is feeble as it stands on one occurrence in each sample of $P$. cingulatus and one single $G$. magnaclavata grain that may represent reworking of older units. 
Modern pollen signature of Tapajós River is characterized by high amount of Poaceae and low Cecropia, consistent with Irion et al. (2006) core data for Tapajós ria, where rise and dominance of Poaceae over Cecropia is registered after $4300 \mathrm{cal} \mathrm{yr} \mathrm{BP.}$ According to the interpretation of Irion et al. (2006), the pollen assemblage of the Tapajós ria indicates that a wet climate remained over large part of the eastern lowland landscape and the shift of the dominant pollen-type is attributed to human occupancy. However, the present data suggest that the fluvial record majorly reflects the riparian vegetation and that an extensive modern human impact does not cause a significant increase in Poaceae as indicated by Xingu ria samples. On the other hand, an Amazon River source and the development of fluvial islands would explain the concomitant increase of Poaceae, Iriartea, and Alternanthera. Between 5000 and $4000 \mathrm{cal} \mathrm{yr} \mathrm{BP,} \mathrm{occurs} \mathrm{an} \mathrm{expansion} \mathrm{of}$ grasslands at Lago Santa Ninha, near Óbidos (Moreira et al., 2009) that may relate to the increase of Poaceae observed in Tapajós ria. After the mid-Holocene, environmental and climatic changes might have been responsible for a shift in the river dynamics and vegetation cover, such as an increase in precipitation due to a southward migration of the ITCZ (Baker et al., 2001; Haug et al., 2001) and rising of sea level. The dominance of Poaceae may be amplified by a reduced presence of massive pollen producers (Bush, 2002), as the early-successional Cecropia, due to less intense fluvial dynamics. As argued by Burn et al. (2010) and corroborated by this study, the palynological record of this site describe the floodplain vegetation, thus cannot be used to infer about changes in the terra firme landscape either by wetness or dryness, instead, better represents changes in the river dynamics and geomorphology.

\section{CONCLUSIONS}

In this study, palynological analysis of riverbed sediments distributed along the Amazon Basin were used to investigate the relationship between the pollen source and the landscape. A significant conclusion of this study is that the palynogical signatures of the Amazon River and tributaries mainly correspond to the floodplain vegetation cover of the lowlands (Figure 41). Fluvial dynamics and the floodplain geomorphology play a important role in controlling the vegetation, which in turn reflects in the pollen load transported and deposited by rivers. The upper reaches of Amazon River, characterized 
by higher erosion, promotes constant succession that reflects in an abundance of Cecropia, whereas the lower reaches, a flatter floodplain covered by lakes, favor the dominance of herbs.

The hindmost palynological signature of the Amazon Basin, at the estuary, results from a major contribution of Solimões and Amazonas rivers. Negro River influence is important at the downstream stretches near the confluence and decreases eastwards, whereas the contribution from other tributaries are minor. Poaceae and other herbs better correlate with várzea grasslands and grow in importance at the stretches between Madeira and Tapajós rivers. Xingu and Tapajós Rivers do not cause a detectable change in the Amazon River palynological signature, thus environmental changes in CentralBrazil region are unlikely to cause major oscillations in the palynological record of the Amazon fan deposits. The dissonance between the modern pollen records and the regional surrounding vegetation raises another evidence of the dubious meaning of Poaceae as a reliable indicator of either open or dry landscapes in the terra firme context. Low values of Poaceae and montane taxa in the Western Amazon reveals that the Andean grasslands does not contribute with relevant amounts of pollen. Extensive anthropogenic disturbance does not cause an expressive change in grass signal, as indicated by Xingu River. These findings can help in a more accurate interpretation of the palynological record of fluvial deposits and the Amazon fan. 


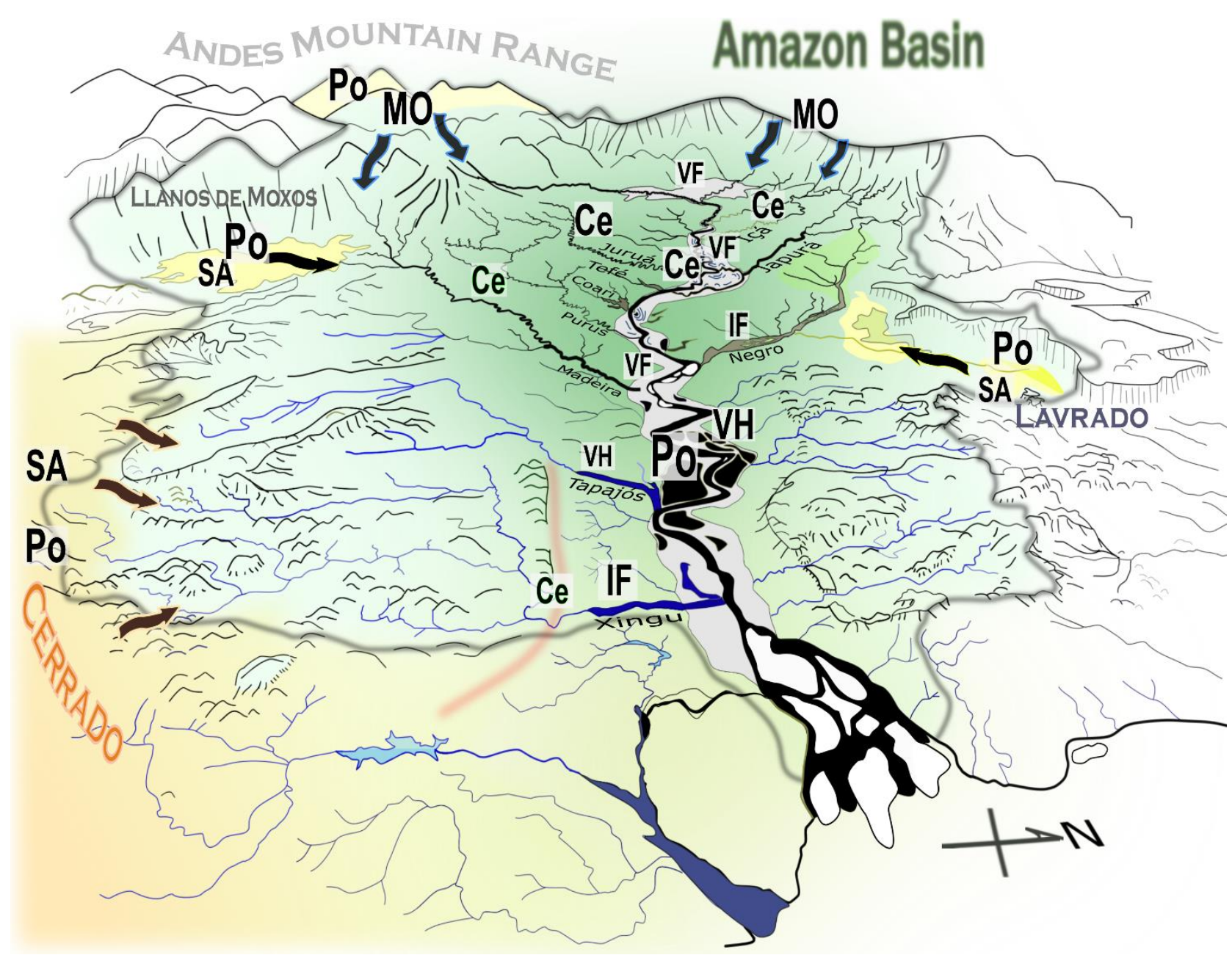

Figure 41 - Source of the main pollen signatures transported by the drainage system of the Amazon Basin. Amazon River in black encompassed by the floodplain represented in gray. Area of the Amazon Basin delimited by a faded gray line. The lowlands, represented by a darker green hue, where most of the pollen is gathered. Arrows indicate extra-Amazonian sources, such as the Andean regions, cerrado, Llanos de Moxos, and the lavrado. $\mathrm{Po}=$ Poaceae, $\mathrm{Ce}=$ Cecropia, VF = Várzea forest, VH = Várzea herbs, IF = Igapó forest, $\mathrm{SA}=$ Savanna taxa, $\mathrm{MO}=$ Montane taxa. The floodplain size and topography are exaggerated. 


\section{REFERENCES}

Adis, J., 1984, 'Seasonal igapó'-forests of Central Amazonian blackwater rivers and their terrestrial arthropod fauna, in Sioli, H. ed., The Amazon, Dordrecht, Springer, p. 245268, doi:10.1007/978-94-009-6542-3_9.

Albert, J.S., Val, P., and Hoorn, C., 2018, The changing course of the Amazon River in the Neogene: center stage for Neotropical diversification: Neotropical Ichthyology, v. 16, p. 1-23, doi:10.1590/1982-0224-20180033.

Almeida-Filho, R., and Miranda, F.P., 2007, Mega capture of the Rio Negro and formation of the Anavilhanas Archipelago, Central Amazônia, Brazil: Evidences in an SRTM digital elevation model: Remote Sensing of Environment, v. 110, p. 387-392, doi:10.1016/j.rse.2007.03.005.

Archer, A.W., 2005, Review of Amazonian depositional systems: , p. 17-39.

Baker, P.A., Seltzer, G.O., Fritz, S.C., Dunbar, R.B., Grove, M.J., Tapia, P.M., Cross, S.L., Rowe, H.D., and Broda, J.P., 2001, The History of South American Tropical Precipitation for the Past 25,000 Years: Science, v. 291, p. 640-643, doi:10.1126/science.291.5504.640.

Behling, H., Keim, G., Irion, G., Junk, W., and Nunes De Mello, J., 2001, Holocene environmental changes in the central amazon basin inferred from Lago Calado (Brazil): Palaeogeography, Palaeoclimatology, Palaeoecology, v. 173, p. 87-101, doi:10.1016/S0031-0182(01)00321-2.

Bertani, T.C., Rossetti, D.F., Hayakawa, E.H., and Cohen, M.C.L., 2015, Understanding Amazonian fluvial rias based on a Late Pleistocene-holocene analog: Earth Surface Processes and Landforms, v. 40, p. 285-292, doi:10.1002/esp.3629.

Bertassoli, D.J. et al., 2017, The Fate of Carbon in Sediments of the Xingu and Tapajós Clearwater Rivers, Eastern Amazon: Frontiers in Marine Science, v. 4, doi:10.3389/fmars.2017.00044.

Bouchez, J., Gaillardet, J., France-Lanord, C., Maurice, L., and Dutra-Maia, P., 2011, Grain size control of river suspended sediment geochemistry: Clues from Amazon River depth profiles: Geochemistry, Geophysics, Geosystems, v. 12, p. 1-24, doi:10.1029/2010GC003380.

Brooks, J., and Shaw, G., 1978, Sporopollenin: A review of its chemistry, palaeochemistry 
and geochemistry: Grana, v. 17, p. 91-97, doi:10.1080/00173137809428858.

Brown, A.G., 1985, The potential use of pollen in the identification of suspended sediment sources: Earth Surface Processes and Landforms, v. 10, p. 27-32, doi:10.1002/esp.3290100106.

Brown, A.G., Carpenter, R.G., and Walling, D.E., 2007, Monitoring fluvial pollen transport, its relationship to catchment vegetation and implications for palaeoenvironmental studies: Review of Palaeobotany and Palynology, v. 147, p. 60-76, doi:10.1016/j.revpalbo.2007.06.005.

Brush, G.S., and Brush, L.M., 1972, Transport of pollen in a sediment-laden channel; a laboratory study: American Journal of Science, v. 272, p. 359-381, doi:10.2475/ajs.272.4.359.

Burn, M.J., Mayle, F.E., and Killeen, T.J., 2010, Pollen-based differentiation of Amazonian rainforest communities and implications for lowland palaeoecology in tropical South America: Palaeogeography, Palaeoclimatology, Palaeoecology, v. 295, p. 1-18, doi:10.1016/j.palaeo.2010.05.009.

Bush, M.B., 1991, Modern pollen-rain data from South and Central America: a test of the feasibility of fine-resolution lowland tropical palynology: The Holocene, v. 1, p. 162167, doi:10.1177/095968369100100209.

Bush, M.B., 2002, On the interpretation of fossil Poaceae pollen in the lowland humid neotropics: Palaeogeography, Palaeoclimatology, Palaeoecology, v. 177, p. 5-17, doi:10.1016/S0031-0182(01)00348-0.

Bush, M.B., De Oliveira, P.E., Colinvaux, P.A., Miller, M.C., and Moreno, J.E., 2004, Amazonian paleoecological histories: One hill, three watersheds: Palaeogeography, Palaeoclimatology, Palaeoecology, v. 214, p. 359-393, doi:10.1016/S00310182(04)00401-8.

Bush, M.B., and Rivera, R., 1998, Pollen Dispersal and Representation in a Neotropical Rain Forest: Global Ecology and Biogeography Letters, v. 7, p. 379, doi:10.2307/2997685.

Campbell, I.A.N.D., 1991, Experimental Mechanical Destruction of Pollen Grains: v. 15, p. 29-33.

Campbell, K.E., 2010, Late Miocene onset of the Amazon River and the Amazon deep- 
sea fan: Evidence from the Foz do Amazonas Basin: COMMENT: Geology, v. 38, p. e212-e212, doi:10.1130/G30633C.1.

Campbell, I.D., 1999, Quaternary pollen taphonomy: examples of differential redeposition and differential preservation: v. 149, p. 245-256.

Campbell, D.G., Daly, D.C., Prance, G.T., and Maciel, U.N., 1986, Quantitative Ecological Inventory of Terra Firme and Varzea Tropical Forest on the Rio Xingu, Brazilian Amazon: Brittonia, v. 38, p. 369, doi:10.2307/2807085.

Campbell, K.E., Frailey, C.D., and Romero-Pittman, L., 2006, The Pan-Amazonian Ucayali Peneplain, late Neogene sedimentation in Amazonia, and the birth of the modern Amazon River system: Palaeogeography, Palaeoclimatology, Palaeoecology, v. 239, p. 166-219, doi:10.1016/j.palaeo.2006.01.020.

Campbell Jr., K.E., Frailey, C.D., and Romero-Pittman, L., 2006, The Pan-Amazonian Ucayali Peneplain, late Neogene sedimentation in Amazonia, and the birth of the modern Amazon River system: Palaeogeography, Palaeoclimatology, Palaeoecology, v. 239, doi:10.1016/j.palaeo.2006.01.020.

Campbell, D.G., Stone, J.L., and Rosas, A., 1992, A comparison of the phytosociology and dynamics of three floodplain (Várzea) forests of known ages, Rio Juruá, western Brazilian Amazon: Botanical Journal of the Linnean Society, v. 108, p. 213-237, doi:10.1111/j.1095-8339.1992.tb00240.x.

Caputo, M.V., and Soares, E.A.A., 2016, Eustatic and tectonic change effects in the reversion of the transcontinental Amazon River drainage system: Brazilian Journal of Geology, v. 46, p. 301-328, doi:10.1590/2317-4889201620160066.

Carim, M.D.J.V., 2016, Estrutura, composição e diversidade em florestas alagáveis de várzea de maré e de igapó e suas relações com variáveis edáficas e o período de inundação no Amapá, Amazônia Oriental, Brasil: Instituto Nacional de Pesquisas da Amazônia, 96 p.

Carneiro, V.M.C., 2004, Composição Florística E Análise Estrutural Da Floresta Primária De Terra Firme Na Bacia Do Rio Cuieiras, Manaus-Am: INPA/UFAM, 61 p.

Catto, N.R., 1985, Hydrodynamic distribution of palynomorphs in a fluvial succession, Yukon: Canadian Journal of Earth Sciences, v. 22, p. 1552-1556, doi:10.1139/e85163. 
Chmura, G.L., and Liu, K.B., 1990, Pollen in the lower Mississippi River: Review of Palaeobotany and Palynology, v. 64, p. 253-261, doi:10.1016/0034-6667(90)90140E.

Colinvaux, P., Moreno Patiño, J.E., and Oliveira, P.E. de, 1999, Amazon pollen manual and atlas/ Manual e atlas palinológico da Amazônia: Amsterdam, Harwood Academic Publishers, $332 \mathrm{p}$.

Colinvaux, P.A., De Oliveira, P.E., Moreno, J.E., Miller, M.C., and Bush, M.B., 1996, A Long Pollen Record from Lowland Amazonia: Forest and Cooling in Glacial Times: Science, v. 274, p. 85-88, doi:10.1126/science.274.5284.85.

Cornu, S., Lucas, Y., Lebon, E., Ambrosi, J.P., Luizão, F., Rouiller, J., Bonnay, M., and Neal, C., 1999, Evidence of titanium mobility in soil profiles, Manaus, central Amazonia: Geoderma, v. 91, p. 281-295, doi:10.1016/S0016-7061(99)00007-5.

Cortez, A.C.A., 2016, Influência da sazonalidade e do modo de coleta na diversidade de fungos decompositores de madeira submersa de ambientes aquáticos da Região Amazônica: UFAM, https://tede.ufam.edu.br/handle/tede/5632.

Costa, M.P.F., 2004, Use of SAR satellites for mapping zonation of vegetation communities in the Amazon floodplain: International Journal of Remote Sensing, v. 25, p. 1817-1835, doi:10.1080/0143116031000116985.

D’Apolito, C., da Silva-Caminha, S.A.F., Jaramillo, C., Dino, R., and Soares, E.A.A., 2018, The Pliocene-Pleistocene palynology of the Negro River, Brazil: Palynology, v. 6122, p. 1-21, doi:10.1080/01916122.2018.1437090.

Dino, R., Soares, E.A.A., Antonioli, L., Riccomini, C., and Nogueira, A.C.R., 2012, Palynostratigraphy and sedimentary facies of Middle Miocene fluvial deposits of the Amazonas Basin, Brazil: Journal of South American Earth Sciences, v. 34, p. 61-80, doi:10.1016/j.jsames.2011.11.008.

Duque, A.J., Cavelier, J., and Posada, A., 2003, Strategies of tree occupation at a local scale in terra firme forests in the Colombian Amazon: Biotropica, v. 35, p. 20-27, doi:10.1111/j.1744-7429.2003.tb00258.x.

Durham, O.C., 1947, The volumetric incidence of atmospheric allergens: Journal of Allergy, v. 18, p. 231-238, doi:10.1016/0021-8707(47)90046-4.

Elsik, W.C., 1966, Biologic Degradation of Fossil Pollen Grains and Spores: 
Micropaleontology, v. 12, p. 515, doi:10.2307/1484797.

Engle, D.L., and Melack, J.M., 1989, Floating meadow epiphyton: biological and chemical features of epiphytic material in an Amazon floodplain lake: Freshwater Biology, v. 22, p. 479-494, doi:10.1111/j.1365-2427.1989.tb01120.x.

Erdtman, G. (Gunner), 1986, Pollen morphology and plant taxonomy: E.J. Brill, 464 p.

Espinoza, J.C., Ronchail, J., Guyot, J.L., Junquas, C., Vauchel, P., Lavado, W., Drapeau, G., and Pombosa, R., 2011, Climate variability and extreme drought in the upper Solimões River (western Amazon Basin): Understanding the exceptional 2010 drought: Geophysical Research Letters, v. 38, p. n/a-n/a, doi:10.1029/2011GL047862.

Faegri, K., and Iversen, J., 1966, Textbook of pollen analysis: Kobenhavn, Munksgaard, $237 \mathrm{p}$.

Feitosa, Y.O., Absy, M.L., Latrubesse, E.M., and Stevaux, J.C., 2015, Late Quaternary vegetation dynamics from central parts of the Madeira River in Brazil: Acta Botanica Brasilica, v. 29, p. 120-128, doi:10.1590/0102-33062014abb3711.

Figueiredo, J., Hoorn, C., van der Ven, P., and Soares, E., 2010, Late Miocene onset of the Amazon River and the Amazon deep-sea fan: Evidence from the Foz do Amazonas Basin: Reply: Geology, v. 38, p. e213-e213, doi:10.1130/G31057Y.1.

Figueiredo, J., Hoorn, C., van der Ven, P., and Soares, E., 2009, Late Miocene onset of the Amazon River and the Amazon deep-sea fan: Evidence from the Foz do Amazonas Basin: Geology, v. 37, p. 619-622, doi:10.1130/G25567A.1.

Fisch, G., Marengo, J.A., and Nobre, C., 1992, Clima da amazônia: Clima da amazônia, v. 80 , p. 1-15, doi:(INPE-11888-PRE/7235).

Folk, R.L., 1974, Petrology of sedimentary rocks: Hemphll Publishing Company, Austin, p. 170, doi:10.1017/CBO9781107415324.004.

Franzinelli, E., and Igreja, H., 2002, Modern sedimentation in the Lower Negro River, Amazonas State, Brazil: Geomorphology, v. 44, p. 259-271, doi:10.1016/S0169555X(01)00178-7.

Fricke, A.T., Nittrouer, C.A., Ogston, A.S., Nowacki, D.J., Asp, N.E., Souza Filho, P.W.M., da Silva, M.S., and Jalowska, A.M., 2017, River tributaries as sediment sinks: Processes operating where the Tapajós and Xingu rivers meet the Amazon tidal river: 
Sedimentology, v. 64, doi:10.1111/sed.12372.

Gama, J.R.V., Botelho, S.A., Bentes-Gama, M. de M., and Scolforo, J.R.S., 2003, Estrutura e potencial futuro de utilização da regeneração natural de floresta de várzea alta no município de Afuá, estado do Pará.: Ciência Florestal, v. 13, p. 71, doi:10.5902/198050981744.

Gama, J.R.V., Souza, A.L. de, Martins, S.V., and Souza, D.R. de, 2005, Comparação entre florestas de várzea e de terra firme do Estado do Pará: Revista Árvore, v. 29, p. 607-616, doi:10.1590/S0100-67622005000400013.

Garreaud, R.D., Vuille, M., Compagnucci, R., and Marengo, J., 2009, Present-day South American climate: Palaeogeography, Palaeoclimatology, Palaeoecology, v. 281, p. 180-195, doi:10.1016/j.palaeo.2007.10.032.

Gentry, A.H., 1992, Tropical Forest Biodiversity: Distributional Patterns and Their Conservational Significance: Oikos, v. 63, p. 19, doi:10.2307/3545512.

Goldstein, S., 1960, Degradation of Pollen by Phycomycetes: Ecology, v. 41, p. 543-545, doi:10.2307/1933329.

Gosling, W.D., Mayle, F.E., Tate, N.J., and Killeen, T.J., 2009, Differentiation between Neotropical rainforest, dry forest, and savannah ecosystems by their modern pollen spectra and implications for the fossil pollen record: Review of Palaeobotany and Palynology, v. 153, p. 70-85, doi:10.1016/j.revpalbo.2008.06.007.

Gosling, W.D., Mayle, F.E., Tate, N.J., and Killeen, T.J., 2005, Modern Pollen-Rain Characteristics of Tall Terra Firme Moist Evergreen Forest, Southern Amazonia: Quaternary Research, v. 64, p. 284-297, doi:10.1016/j.yqres.2005.08.008.

Govin, A., Chiessi, C.M., Zabel, M., Sawakuchi, A.O., Heslop, D., Hörner, T., Zhang, Y., and Mulitza, S., 2014, Terrigenous input off northern South America driven by changes in Amazonian climate and the North Brazil Current retroflection during the last 250 ka: Climate of the Past, v. 10, p. 843-862, doi:10.5194/cp-10-843-2014.

Grace, J.B., 1993, The adaptive significance of clonal reproduction in angiosperms: an aquatic perspective: Aquatic Botany, v. 44, p. 159-180, doi:10.1016/03043770(93)90070-D.

Guyot, J.L., Jouanneau, J.M., Soares, L., Boaventura, G.R., Maillet, N., and Lagane, C., 2007, Clay mineral composition of river sediments in the Amazon Basin: Catena, v. 
71, p. 340-356, doi:10.1016/j.catena.2007.02.002.

Haberle, S., 1997, Upper Quaternary vegetation and climate history of the Amazon Basin: correlating marine and terrestrial pollen records: Proceedings of the Ocean Drilling Program, Scientific Results, v. 155, p. 381-396, doi:10.2973/odp.proc.sr.155.225.1997.

Haberle, S.G., and Maslin, M. a, 1999, Late Quaternary Vegetation and Climate Change in the Amazon Basin Based on a 50,000 Year Pollen Record from the Amazon Fan, ODP Site 932: Quaternary Research, v. 51, p. 27-38, doi:10.1006/qres.1998.2020. Häggi, C., Sawakuchi, A.O., Chiessi, C.M., Mulitza, S., Mollenhauer, G., Sawakuchi, H.O., Baker, P.A., Zabel, M., and Schefuß, E., 2016, Origin, transport and deposition of leaf-wax biomarkers in the Amazon Basin and the adjacent Atlantic: Geochimica et Cosmochimica Acta, v. 192, p. 149-165, doi:10.1016/j.gca.2016.07.002.

Hammer, Ø., Harper, D.A.T. a. T., and Ryan, P.D., 2001, PAST: Paleontological Statistics Software Package for Education and Data Analysis: Palaeontologia Electronica, v. 4(1), p. 1-9, doi:10.1016/j.bcp.2008.05.025.

Haug, G.H., Hughen, K.A., Sigman, D.M., Peterson, L.C., and Röhl, U., 2001, Southward Migration of the Intertropical Convergence Zone Through the Holocene: Science, v. 293, p. 1304-1308, doi:10.1126/science.1059725.

Helena, D., Costa, M., Natalino, J., Silva, M., Olegário, J., and Carvalho, P. De, 2008, Crescimento de árvores em uma área de terra firme na Floresta Nacional do Tapajós após a colheita de madeira: Rev. ciênc. agrár, v. 50, p. 63-76.

Henderson, A., 1990, Arecaceae. Part I. Introduction and the Iriarteinae: Flora Neotropica, v. 53 , p. $1-100$, doi:10.2307/2805360.

Hess, L.L., Melack, J.M., Novo, E.M.L.M., Barbosa, C.C.F., and Gastil, M., 2003, Dualseason mapping of wetland inundation and vegetation for the central Amazon basin: Remote Sensing of Environment, v. 87, p. 404-428, doi:10.1016/j.rse.2003.04.001. Hill, M.O., and Gauch, H.G., 1980, Detrended Correspondence Analysis: An Improved Ordination Technique.: Vegetatio, v. 42, p. 47-58, www.jstor.org/stable/20145789. Hooghiemstra, H., 1984, Vegetational and climatic history of the high plain of Bogotá,

Colombia : a continuous record of the last 3.5 million years: J. Cramer, 368 p. Hoorn, C., 1993, Marine incursions and the influence of Andean tectonics on the Miocene 
depositional history of northwestern Amazonia: results of a palynostratigraphic study: Palaeogeography, Palaeoclimatology, Palaeoecology, v. 105, p. 267-309, doi:10.1016/0031-0182(93)90087-Y.

Hoorn, C., 1997, Palynology of the Pleistocene glacial/interglacial cycles of the Amazon Fan (Holes 940A, 944A, and 946A), in Proceedings of the Ocean Drilling Program, 155 Scientific Results, Ocean Drilling Program, v. 155, p. 531-538, doi:10.2973/odp.proc.sr.155.226.1997.

Hoorn, C., Bogotá-A, G.R., Romero-Baez, M., Lammertsma, E.I., Flantua, S.G.A., Dantas, E.L., Dino, R., do Carmo, D.A., and Chemale, F., 2017, The Amazon at sea: Onset and stages of the Amazon River from a marine record, with special reference to Neogene plant turnover in the drainage basin: Global and Planetary Change, v. 153, p. 51-65, doi:10.1016/j.gloplacha.2017.02.005.

Hopkins, J.S., 1950, Differential Flotation and Deposition of Coniferous and Deciduous Tree Pollen: Ecology, v. 31, p. 633-641, doi:10.2307/1931580.

Horbe, A.M.C., Behling, H., Nogueira, A.C.R., and Mapes, R., 2011, Environmental changes in the western Amazonia: Morphological framework, geochemistry, palynology and radiocarbon dating data: Anais da Academia Brasileira de Ciencias, v. 83, p. 863-874, doi:10.1590/S0001-37652011005000030.

Householder, J.E., Wittmann, F., Tobler, M.W., and Janovec, J.P., 2015, Montane bias in lowland Amazonian peatlands: Plant assembly on heterogeneous landscapes and potential significance to palynological inference: Palaeogeography, Palaeoclimatology, Palaeoecology, v. 423, p. 138-148, doi:10.1016/j.palaeo.2015.01.029.

Irion, G., Bush, M.B., Nunes de Mello, J.A., Stüben, D., Neumann, T., Müller, G., Morais de, J.O., and Junk, J.W., 2006, A multiproxy palaeoecological record of Holocene lake sediments from the Rio Tapajós, eastern Amazonia: Palaeogeography, Palaeoclimatology, Palaeoecology, v. 240, p. 523-535, doi:10.1016/j.palaeo.2006.03.005.

Irion, G., de Mello, J.A.S.N., Morais, J., Piedade, M.T.F., Junk, W.J., and Garming, L., 2010, Development of the Amazon Valley During the Middle to Late Quaternary: Sedimentological and Climatological Observations, in The Canadian veterinary 
journal. La revue vétérinaire canadienne, v. 37, p. 27-42, doi:10.1007/978-90-4818725-6_2.

Jacobs, J., Lange, L., and Olson, S., 1975, Tropical Ecological Systems (F. B. Golley \& E. Medina, Eds.): New York, Springer-Verlag, Ecological Studies, v. 11, doi:10.1007/978-3-642-88533-4.

Jaramillo, C. et al., 2017, Miocene flooding events of western Amazonia: Science Advances, v. 3, p. e1601693, doi:10.1126/sciadv.1601693.

Johnsson, M.J., and Meade, R.H., 1990, Chemical Weathering of Fluvial Sediments During Alluvial Storage: The Macuapanim Island Point Bar, Solimoes River, Brazil: SEPM Journal of Sedimentary Research, v. Vol. 60, p. 827-842, doi:10.1306/212F9296-2B24-11D7-8648000102C1865D.

Junk, W.J., 1989, Flood tolerance and tree distribution in central Amazonian floodplains, in Tropical Forests, Elsevier, v. 44, p. 47-64, doi:10.1016/B978-0-12-3535504.50012-5.

Junk, W.J., 1997, The Central Amazon Floodplain (W. J. Junk, Ed.): Berlin, Heidelberg, Springer Berlin Heidelberg, Ecological Studies, v. 126, 525 p., doi:10.1007/978-3662-03416-3.

Junk, W.J., Bayley, P.B., and Sparks, R.E., 1989, The flood pulse concept in riverfloodplain systems: Proceedings of the International Large River Symposium. Can. Spec. Publ. Fish. Aquati. Sci., v. 106, p. 110-127, doi:10.1371/journal.pone.0028909. Junk, W.J., and Piedade, M.T.F., 1993, Herbaceous plantes of the Amazon floodplain near Manaus: species diversity and adaptations to the flood pulse: Amazoniana, v. 12, p. 467-484.

Junk, W.J., Piedade, M.T.F., Schöngart, J., Cohn-Haft, M., Adeney, J.M., and Wittmann, F., 2011, A classification of major naturally-occurring amazonian lowland wetlands: Wetlands, v. 31, p. 623-640, doi:10.1007/s13157-011-0190-7.

Kalliola, R., Salo, J., Puhakka, M., and Rajasilta, M., 1991, New Site Formation and Colonizing Vegetation in Primary Succession on the Western Amazon Floodplains: The Journal of Ecology, v. 79, p. 877, doi:10.2307/2261087.

Kubitzki, K., 1989, The ecogeographical differentiation of Amazonian inundation forests:

Plant Systematics and Evolution, v. 162, p. 285-304, doi:10.1007/BF00936922. 
Latrubesse, E.M., Cozzuol, M., da Silva-Caminha, S.A.F., Rigsby, C.A., Absy, M.L., and Jaramillo, C., 2010, The Late Miocene paleogeography of the Amazon Basin and the evolution of the Amazon River system: Earth-Science Reviews, v. 99, p. 99-124, doi:10.1016/j.earscirev.2010.02.005.

Latrubesse, E.M., da Silva, S.A.F., Cozzuol, M., and Absy, M.L., 2007, Late Miocene continental sedimentation in southwestern Amazonia and its regional significance: Biotic and geological evidence: Journal of South American Earth Sciences, v. 23, p. 61-80, doi:10.1016/j.jsames.2006.09.021.

Ledru, M.-P., Salatino, M.L.F., Ceccantini, G., Salatino, A., Pinheiro, F., and Pintaud, J.C., 2007, Regional assessment of the impact of climatic change on the distribution of a tropical conifer in the lowlands of South America: Diversity and Distributions, v. 13, p. 761-771, doi:10.1111/j.1472-4642.2007.00389.x.

Leopoldo, P.R., Franken, W., Salati, E., and Ribeiro, M.N., 1987, Towards a water balance in the Central Amazonian region: Experientia, v. 43, p. 222-233, doi:10.1007/BF01945545.

Lombardi, J.A., and Biral, L., 2016, Flora das cangas da Serra dos Carajás, Pará, Brasil: Celastraceae: Rodriguésia, v. 67, p. 1285-1290, doi:10.1590/2175-7860201667528. Lorente, F.L., Buso Junior, A.A., de Oliveira, P.E., and Pessenda, L.C.R., 2017, Atlas Palinológico: FEALQ, 333 p., http://fealq.org.br/produto/atlas-palinologico/.

Maciel, E.A., Oliveira-Filho, A.T., and Eisenlohr, P. V., 2016, Prioritizing rare tree species of the Cerrado-Amazon ecotone: warnings and insights emerging from a comprehensive transitional zone of South America: Natureza e Conservacao, v. 14, p. 74-82, doi:10.1016/j.ncon.2016.10.002.

Maia, R.G.N., Godoy, H.K., Yamaguti, H.S., Moura, P.A. de, Costa, F.S.F. da, Holanda, M.A. de, and Costa, J.A. de, 1977, Projeto carvão no Alto Solimões: relatório final:, http://rigeo.cprm.gov.br/xmlui/handle/doc/9392 (accessed January 2019).

Marchant, R. et al., 2002, Distribution and ecology of parent taxa of pollen lodged within the Latin American Pollen Database: Review of Palaeobotany and Palynology, v. 121, p. 1-75, doi:10.1016/S0034-6667(02)00082-9.

Marchioretto, M.S., Teresinha, S., Miotto, S., and Siqueira, C. De, 2010, O gênero Pfaffia Mart. (Amaranthaceae) no Brasil: Hoehnea, v. 37, p. 461-511. 
Marengo, J.A., 1992, Interannual variability of surface climate in the Amazon basin: International Journal of Climatology, v. 12, p. 853-863, doi:10.1002/joc.3370120808. Martinez, J.M., and Le Toan, T., 2007, Mapping of flood dynamics and spatial distribution of vegetation in the Amazon floodplain using multitemporal SAR data: Remote Sensing of Environment, v. 108, p. 209-223, doi:10.1016/j.rse.2006.11.012.

Maslin, M.A., Ettwein, V.J., Wilson, K.E., Guilderson, T.P., Burns, S.J., and Leng, M.J., 2011, Dynamic boundary-monsoon intensity hypothesis: Evidence from the deglacial Amazon River discharge record: Quaternary Science Reviews, v. 30, p. 3823-3833, doi:10.1016/j.quascirev.2011.10.007.

Meade, R.H., 1994, Suspended sediments of the modern Amazon and Orinoco rivers: Quaternary International, v. 21, p. 29-39, doi:10.1016/1040-6182(94)90019-1.

Mertes, L.A.K., Daniel, D.L., Melack, J.M., Nelson, B., Martinelli, L.A., and Forsberg, B.R., 1995, Spatial patterns of hydrology, geomorphology, and vegetation on the floodplain of the Amazon river in Brazil from a remote sensing perspective: Geomorphology, v. 13, p. 215-232, doi:10.1016/0169-555X(95)00038-7.

Mertes, L.A.K., Dunne, T., and Martinelli, L.A., 1996, Channel-floodplain geomorphology along the Solimões-Amazon River, Brazil: Geological Society of America Bulletin, v. 108, p. 1089-1107, doi:10.1130/0016-7606(1996)108<1089:CFGATS>2.3.CO;2.

Miguez-Macho, G., and Fan, Y., 2012, The role of groundwater in the Amazon water cycle: 1. Influence on seasonal streamflow, flooding and wetlands: Journal of Geophysical Research Atmospheres, v. 117, p. 1-30, doi:10.1029/2012JD017539.

Miranda, I.S., Absy, M.L., and Rebêlo, G.H., 2003, Community structure of woody plants of Roraima savannahs, Brazil: Plant Ecology, v. 164, p. 109-123, doi:10.1023/A:1021298328048.

Montero, J.C., and Latrubesse, E.M., 2013, The igapó of the Negro River in central Amazonia: Linking late-successional inundation forest with fluvial geomorphology: Journal of South American Earth Sciences, v. 46, p. 137-149, doi:10.1016/j.jsames.2013.05.009.

Montero, J.C., Piedade, M.T.F., and Wittmann, F., 2014, Floristic variation across $600 \mathrm{~km}$ of inundation forests (Igapó) along the Negro River, Central Amazonia: Hydrobiologia, v. 729, p. 229-246, doi:10.1007/s10750-012-1381-9. 
Moran, E.F., Brondizio, E., Mausel, P., and Wu, Y., 1994, Amazonian Integrating Vegetation, and succession can inform future policies: v. 44, p. 329-338, doi:10.2307/1312383.

Moreira-Turcq, P., Jouanneau, J.M., Turcq, B., Seyler, P., Weber, O., and Guyot, J.L., 2004, Carbon sedimentation at Lago Grande de Curuai, a floodplain lake in the low Amazon region: Insights into sedimentation rates: Palaeogeography, Palaeoclimatology, Palaeoecology, v. 214, p. 27-40, doi:10.1016/j.palaeo.2004.06.013.

Moreira-turcq, P., Seyler, P., Guyot, J.L., and Etcheber, H., 2003, Exportation of organic carbon from the Amazon River and its main tributaries: v. 1344, p. 1329-1344, doi:10.1002/hyp.1287.

Moreira, L.S., Moreira-Turcq, P.F., Cordeiro, R.C., and Turcq, B.J., 2009, Reconstituição paleoambiental do Lago Santa Ninha, Várzea do Lago Grande de Curuai, Pará, Brasil: Acta Amazonica, v. 39, p. 609-616, doi:10.1590/S0044-59672009000300016.

Moss, P.T., Kershaw, A.P., and Grindrod, J., 2005, Pollen transport and deposition in riverine and marine environments within the humid tropics of northeastern Australia: Review of Palaeobotany and Palynology, v. 134, p. 55-69, doi:10.1016/j.revpalbo.2004.11.003.

Muller, J., 1959, Palynology of Recent Orinoco Delta and Shelf Sediments: Reports of the Orinoco Shelf Expedition; Volume 5: Micropaleontology, v. 5, p. 1, doi:10.2307/1484153.

Nogueira, A.C.R., Silveira, R., and Guimarães, J.T.F., 2013, Neogene-Quaternary sedimentary and paleovegetation history of the eastern Solimões Basin, central Amazon region: Journal of South American Earth Sciences, v. 46, p. 89-99, doi:10.1016/j.jsames.2013.05.004.

Oliveira, S.D.F., and Lima, M.R. De, 1990, Acritarcas silurianos da Formação Trombetas, bacia do Amazonas: Revista do Instituto Geológico, v. 8-11, p. 43-50, doi:10.5935/0100-929X.19900005.

Ortuño, T., and Borsch, T., 2006, A further new species of Gomphrena (Amaranthaceae, Gomphrenoideae) from the dry valleys of Bolivia: Kew Bulletin, v. 61, p. 565-568.

Parolin, P., 2002, Life history and environment of Cecropia latiloba in Amazonian 
floodplains.: Revista de biologia tropical, v. 50, p. 531-45, http://www.ncbi.nlm.nih.gov/pubmed/12298284.

Pejrup, M., 1988, The Triangular Diagram Used for Classification of Estuarine Sediments:

A New Approach, in Tide-Influenced Sedimentary Environments and Facies, Dordrecht, Springer Netherlands, v. 6, p. 289-300, doi:10.1007/978-94-015-77625_21.

Pires, J.M., 1984, The Amazonian forest, in Sioli, H. ed., The Amazon, Dordrecht, Springer, p. 581-602, doi:10.1007/978-94-009-6542-3_22.

Pires, J.M., and Prance, G.T., 1985, The vegetation types of the Brazilian Amazon, in G.T.Prance, T.E.L. ed., Key environments: Amazonia, Pergamon Press, p. 110-145. Pitman, N.C.A., Terborgh, J., Silman, M.R., and V., P.N., 1999, Tree Species Distributions in an Upper Amazonian Forest: Ecology, v. 80, p. 2651, doi:10.2307/177247.

Pitman, N.C.A., Terborgh, J.W., Silman, M.R., V., P.N., Neill, D.A., Ceron, C.E., Palacios, W.A., and Aulestia, M., 2001, Dominance and Distribution of Tree Species in Upper Amazonian Terra Firme Forests: Ecology, v. 82, p. 2101, doi:10.2307/2680219.

Pocknall, D.T., and Jarzen, D.M., 2012, Grimsdalea magnaclavata Germeraad, Hopping \& Muller: an enigmatic pollen type from the Neogene of northern South America: Palynology, v. 36, p. 134-143, doi:10.1080/01916122.2011.642258.

Prance, G.T., 1979, Notes on the Vegetation of Amazonia III. The Terminology of Amazonian Forest Types Subject to Inundation: Brittonia, v. 31, p. 26, doi:10.2307/2806669.

Putzer, H., 1984, The geological evolution of the Amazon basin and its mineral resources, in Sioli, H. ed., The Amazon, Dordrecht, Springer, p. 15-46, doi:10.1007/978-94-0096542-3_2.

Rankin-de-Mérona, J.M., Prance, G.T., Hutchings, R.W., Silva, M.F. da, Rodrigues, W.A., and Uehling, M.E., 1992, Preliminary Results of a Large-Scale Tree Inventory of upland Rain Forest in the Central Amazon: Acta Amazonica, v. 22, p. 493-534, doi:10.1590/1809-43921992224534.

Roddaz, M., Hermoza, W., Mora, A., Baby, P., Parra, M., Christophoul, F., Brusset, S., and Espurt, N., 2009, Cenozoic Sedimentary Evolution of the Amazonian Foreland Basin System, in Hoorn, H. and Wesselingh, F.P. eds., Amazonia: Landscape and 
Species Evolution, Oxford, UK, Wiley-Blackwell Publishing Ltd., p. 61-88, doi:10.1002/9781444306408.ch5.

Rodríguez-Zorro, P.A., Enters, D., Hermanowski, B., da Costa, M.L., and Behling, H., 2015, Vegetation changes and human impact inferred from an oxbow lake in southwestern Amazonia, Brazil since the 19th century: Journal of South American Earth Sciences, v. 62, p. 186-194, doi:10.1016/j.jsames.2015.06.003.

Rösel, S., Rychła, A., Wurzbacher, C., and Grossart, H.-P., 2012, Effects of pollen leaching and microbial degradation on organic carbon and nutrient availability in lake water: Aquatic Sciences, v. 74, p. 87-99, doi:10.1007/s00027-011-0198-3.

Rossetti, D.F. et al., 2015, Mid-Late Pleistocene OSL chronology in western Amazonia and implications for the transcontinental Amazon pathway: Sedimentary Geology, v. 330, p. 1-15, doi:10.1016/j.sedgeo.2015.10.001.

Rossetti, D.F., Mann de Toledo, P., and Góes, A.M., 2005, New geological framework for Western Amazonia (Brazil) and implications for biogeography and evolution: Quaternary Research, v. 63, p. 78-89, doi:10.1016/j.yqres.2004.10.001.

Roubik, D.W., and Moreno P., J.E., 1991, Pollen and spores of Barro Colorado Island [Panama].: St Louis, Cambridge University Press, v. 1, 256 p.

Sá, N. de P., Absy, M.L., and Soares, E.A.A., 2016, Late Holocene paleoenvironments of the floodplain of the Solimões River, Central Amazonia, based on the palynological record of Lake Cabaliana: Acta Botanica Brasilica, v. 30, p. 473-485, doi:10.1590/0102-33062016abb0250.

Sachs, J.P., Sachse, D., Smittenberg, R.H., Zhang, Z., Battisti, D.S., and Golubic, S., 2009, Southward movement of the Pacific intertropical convergence zone AD 14001850: Nature Geoscience, v. 2, p. 519-525, doi:10.1038/ngeo554.

Salgado-Labouriau, M.L., 2007, Critérios e técnicas para o Quaternário: São Paulo, Edgard Blucher, $387 \mathrm{p}$.

Salo, J., Kalliola, R., Häkkinen, I., Mäkinen, Y., Niemelä, P., Puhakka, M., and Coley, P.D., 1986, River dynamics and the diversity of Amazon lowland forest: Nature, v. 322, p. 254-258, doi:10.1038/322254a0.

Sandweiss, D.H., Richardson, J.B., Reitz, E.J., Rollins, H.B., and Maasch, K.A., 1996, Geoarchaeological Evidence from Peru for a 5000 Years B.P. Onset of El Nino: 
Science, v. 273, p. 1531-1533, doi:10.1126/science.273.5281.1531.

Santamaría, L., 2002, Why are most aquatic plants widely distributed? Dispersal, clonal growth and small-scale heterogeneity in a stressful environment: Acta Oecologica, v. 23, p. 137-154, doi:10.1016/S1146-609X(02)01146-3.

Santos, J.O.S., Hartmann, L.A., Gaudette, H.E., Groves, D.I., Mcnaughton, N.J., and Fletcher, I.R., 2000, A New Understanding of the Provinces of the Amazon Craton Based on Integration of Field Mapping and U-Pb and Sm-Nd Geochronology: Gondwana Research, v. 3, p. 453-488, doi:10.1016/S1342-937X(05)70755-3.

Schneider, T., Bischoff, T., and Haug, G.H., 2014, Migrations and dynamics of the intertropical convergence zone.: Nature, v. 513, p. 45-53, doi:10.1038/nature13636.

Schulte, F., Lingott, J., Panne, U., and Kneipp, J., 2008, Chemical Characterization and Classification of Pollen: Analytical Chemistry, v. 80, p. 9551-9556, doi:10.1021/ac801791a.

Scudeller, V.V., 2018, Do the Igapó Trees Species are Exclusive to this Phytophysiognomy? Or Geographic Patterns of Tree Taxa in the Igapó Forest Negro River - Brazilian Amazon, in Myster, R.W. ed., Igapó (Black-water flooded forests) of the Amazon Basin, Cham, Springer International Publishing, p. 185-207, doi:10.1007/978-3-319-90122-0_12.

Scudeller, V.V., and Souza, A.M.G. de, 2009, Florística da mata de igapó na Amazônia central, in Santos-Silva, E.N. and Scudeller, V.V. eds., Diversidade Biológica e Sociocultural do Baixo Rio Negro, Amazônia Central, Manaus, v. 2, p. 97-108.

Scudeller, V.V., and Vegas-Vilarrúbia, T., 2018, Distribution and $\beta$-diversity of tree species in igapó forests (Negro River basin, Brazilian Amazon) (M. De Cáceres, Ed.): Journal of Vegetation Science, p. 0-2, doi:10.1111/jvs.12680.

Silva e Silva, W.L. da, Gurgel, E.S.C., Santos, J.U.M. dos, and Silva, M.F. da, 2013, Inventário e distribuição geográfica de Leguminosae no arquipélago de Marajó, PA, Brasil: Hoehnea, v. 40, p. 627-647, doi:10.1590/S2236-89062013000400006.

Silva, K.E. da, Martins, S.V., Ribeiro, C.A.A.S., Santos, N.T., and Azevedo, C.P. de, 2016, Structure of 15 Hectares Permanent Plots of Terra Firme Dense Forest in Central Amazon: Revista Árvore, v. 40, p. 603-615, doi:10.1590/0100-67622016000400004. Sioli, H., 1984, The Amazon and its main affluents: Hydrography, morphology of the river 
courses, and river types, in Sioli, H. ed., The Amazon, Dordrecht, Springer, p. 127165, doi:10.1007/978-94-009-6542-3_5.

Sioli, H., 1975, Tropical Rivers as Expressions of Their Terrestrial Environments, in Golley, F.B. and Medina, E. eds., Tropical Ecological Systems, New York, SpringerVerlag, p. 275-288, doi:10.1007/978-3-642-88533-4_19.

Smirnov, A., Chmura, G.L., and Lapointe, M.F., 1996, Spatial distribution of suspended pollen in the Mississippi River as an example of pollen transport in alluvial channels: Review of Palaeobotany and Palynology, v. 92, p. 69-81, doi:10.1016/00346667(95)00098-4.

Soares, E.A.A., D’Apolito, C., Jaramillo, C., Harrington, G., Caputo, M.V., Barbosa, R.O., Bonora dos Santos, E., Dino, R., and Gonçalves, A.D., 2017, Sedimentology and Palynostratigraphy of a Pliocene-Pleistocene (Piacenzian to Gelasian) deposit in the lower Negro River: Implications for the establishment of large rivers in Central Amazonia: Journal of South American Earth Sciences, v. 79, p. 215-229, doi:10.1016/j.jsames.2017.08.008.

Sousa, M.M.P., 2012, Estrutura e composição das comunidades de árvores na bacia do alto rio Negro: INPA/UFAM, $88 \mathrm{p}$.

ter Steege, H. et al., 2013, Hyperdominance in the Amazonian Tree Flora: Science, v. 342, p. 1243092-1243092, doi:10.1126/science.1243092.

Stockmarr, J., 1971, Tablets with spores used in absolute pollen analysis: Pollen et Spores, v. XIII, p. 615-621.

Sun, S., Schefuß, E., Mulitza, S., Chiessi, C.M., Sawakuchi, A.O., Zabel, M., Baker, P.A., Hefter, J., and Mollenhauer, G., 2017, Origin and processing of terrestrial organic carbon in the Amazon system: Lignin phenols in river, shelf, and fan sediments: Biogeosciences, v. 14, p. 2495-2512, doi:10.5194/bg-14-2495-2017.

Toledo, M., and Salick, J., 2006, Secondary succession and indigenous management in semideciduous forest fallows of the Amazon basin: Biotropica, v. 38, p. 161-170, doi:10.1111/j.1744-7429.2006.00120.x.

Traverse, A., 2007, Paleopalynology: Dordrecht, Springer Netherlands, Topics in Geobiology, v. 28, 813 p., doi:10.1007/978-1-4020-5610-9.

Vavrdová, M., Isaacson, P.E., and Díaz-Martínez, E., 2011, Early Silurian-Early Devonian 
acritarchs and prasinophytes from the Ananea and San Gabán Formations, southern Peru and their paleogeographic implications: Revista Española de Micropaleontología, v. 43, p. 157.

Vital, H., and Stattegger, K., 2000, Major and trace elements of stream sediments from the lowermost Amazon River:

Vormisto, J., Svenning, J.-C., Hall, P., and Balslev, H., 2004, Diversity and dominance in palm (Arecaceae) communities in terra firme forests in the western Amazon basin: $J$ Ecology, v. 92, p. 577-588, doi:10.1111/j.0022-0477.2004.00904.x.

Waliser, D.E., and Gautier, C., 1993, A Satellite-derived Climatology of the ITCZ: Journal of Climate, v. 6, p. 2162-2174, doi:10.1175/15200442(1993)006<2162:ASDCOT>2.0.CO;2.

Wallace, A.R., 1889, A narrative of travels on the Amazon and Rio Negro : with an account of the native tribes, and observations of the climate, geology, and natural history of the Amazon Valley / by Alfred Russel Wallace; with a biographical introduction by the editor.: London ;, Ward, Lock, 1-432 p., doi:10.5962/bhl.title.2764.

Wanderley-Filho, J.R., Eiras, J.F., da Cruz Cunha, P.R., and van der Ven, P.H., 2009, The Paleozoic Solimões and Amazonas Basins and the Acre Foreland Basin of Brazil, in Hoorn, C. and Wesselingh, F.P. eds., Amazonia: Landscape and Species Evolution, Oxford, Wiley-Blackwell Publishing Ltd., p. 29-37, doi:10.1002/9781444306408.ch3.

Wang, H., and Fu, R., 2007, The Influence of Amazon Rainfall on the Atlantic ITCZ through Convectively Coupled Kelvin Waves: Journal of Climate, v. 20, p. 11881201, doi:10.1175/JCLI4061.1.

Weng, C., Bush, M.B., and Silman, M.R., 2004, An analysis of modern pollen rain on an elevational gradient in southern Peru: Journal of Tropical Ecology, v. 20, p. 113-124, doi:10.1017/S0266467403001068.

Whitney, B.S., Smallman, T.L., Mitchard, E.T., Carson, J.F., Mayle, F.E., and Bunting, M.J., 2018, Constraining pollen-based estimates of forest cover in the Amazon: A simulation approach: The Holocene, p. 095968361881039, doi:10.1177/0959683618810394.

Wijmstra, T.A., and van der Hammen, T., 1966, Palynological data on the history of 
tropical savannas in northern South America: LEIDSE GEOLOGISCHE MEDEDELINGEN, v. 38, p. 71-90, doi:0075-8639.

Williams, E., Dall' Antonia, A., Dall' Antonia, V., Almeida, J.M. de, Suarez, F., Liebmann, B., and Malhado, A.C.M., 2005, The drought of the century in the Amazon Basin: an analysis of the regional variation of rainfall in South America in 1926: Acta Amazonica, v. 35, p. 231-238, doi:10.1590/S0044-59672005000200013.

Wittmann, F., Anhuf, D., and Funk, W.J., 2002, Tree species distribution and community structure of central Amazonian várzea forests by remote-sensing techniques: Journal of Tropical Ecology, v. 18, p. 805-820, doi:10.1017/S0266467402002523.

Wittmann, F., and Householder, E., 2017, Why Rivers Make the Difference: A Review on the Phytogeography of Forested Floodplains in the Amazon Basin: Forest structure, function and dynamics in Western Amazonia, p. 125-144, doi:10.1002/9781119090670.ch6.

Wittmann, F., and Junk, W.J., 2003, Sapling communities in Amazonian white-water forests: Journal of Biogeography, v. 30, p. 1533-1544, doi:10.1046/j.13652699.2003.00966.x.

Wittmann, F., Schöngart, J., and Junk, W.J., 2011, Amazonian Floodplain Forests: v. 210, doi:10.1007/978-90-481-8725-6.

Wittmann, F., Schöngart, J., Montero, J.C., Motzer, T., Junk, W.J., Piedade, M.T.F., Queiroz, H.L., and Worbes, M., 2006, Tree species composition and diversity gradients in white-water forests across the Amazon Basin: Journal of Biogeography, v. 33, p. 1334-1347, doi:10.1111/j.1365-2699.2006.01495.x.

Worbes, M., Klinge, H., Revilla, J.D., and Martius, C., 1992, On the dynamics, floristic subdivision and geographical distribution of várzea forests in Central Amazonia: Journal of Vegetation Science, v. 3, p. 553-564, doi:10.2307/3235812.

Wurzbacher, C., Rösel, S., Rychła, A., and Grossart, H., 2014, Importance of Saprotrophic Freshwater Fungi for Pollen Degradation (D. E. Rozen, Ed.): PLoS ONE, v. 9, p. e94643, doi:10.1371/journal.pone.0094643.

Zhu, Y., 2003, Pollen transport in the Shiyang River drainage, arid China: Chinese Science Bulletin, v. 48, p. 1499, doi:10.1360/02wd0261. 
APPENDIX 1

Ecology of parent taxa 
(VA-Várzea, TF-Terra firma, CE-Cerrado, CACampinarana, MO-Montane *Commonly found in)

\section{Amaranthaceae}

Alternanthera
Amaranthus
Chenopodium
Chamissoa
Gomphrena
Irenella
Iresine
Pfaffia
Amaranthaceae

$\begin{array}{ll}\text { HERB } & \text { VA* } \\ \text { HERB } & V^{*} \\ \text { HERB } & V^{*} \\ \text { HERB } & \text { VA } \\ \text { HERB } & \text { Dry/CE/MO } \\ \text { HERB } & \text { TF } \\ \text { HERB } & \text { Dry/TF - open } \\ \text { HERB } & \text { DRY/VA/CE/MO } \\ \text { HERB } & \text { TF/VA }\end{array}$

Anacardiaceae

Anacardium

Lithraea

Schinus

Spondias

Tapirira

Anacardiaceae

\section{Apiaceae}

Apiaceae

\section{Aquifoliaceae}

Ilex

\section{Araceae}

Spathiphyllum

\section{Araliaceae}

Dendropanax

Schefflera

\section{Arecaceae}

Attalea

Astrocatyum

Elaeis

Euterpe
ARBO

ARBO

ARBO

ARBO

ARBO

ARBO

HERB

ARBO

HERB

HERB

ARBO

PALM

PALM

PALM

PALM
$\mathrm{TF}^{*}$

VA

TF*

TF

TF/CA

TF/VA

VA/TF/MO

Epiphyta

TF*

$\mathrm{TF}^{*} / \mathrm{VA} / \mathrm{CA}$

VA/TF

TF/VA

TF

VA/TF 


$\begin{array}{lll}\text { Iriartea } & \text { PALM } & \mathrm{VA} / \mathrm{TF} \\ \text { Mauritia } & \text { PALM } & \mathrm{VA}^{*} / \\ \text { Mauritiella } & \text { PALM } & \mathrm{VA}^{*} / \\ \text { Socratea } & \text { PALM } & \mathrm{VA} \\ \text { Wettinia } & \text { PALM } & \mathrm{TF} / \mathrm{MO} \\ \text { Arecaceae } & \text { PALM } & \mathrm{VA} / \mathrm{TF}\end{array}$

Asteraceae

Ambrosia

HERB VA

Elephantopus

HERB VA

Vernonia

HERB

TF/VA

Liguliflorae

Asteraceae

HERB

VA

Begoniaceae

Begonia

HERB

$V A^{*}$

Betulaceae

Alnus

ARBO

MO

Bignoniaceae

Spathodea-Type

ARBO

TF

Tabebuia

ARBO

TF

Tecoma

ARBO

TF

Boraginaceae

Cordia

ARBO

VA/TF/Dry - savanna

Heliotropium

HERB

$\mathrm{VA}^{*}$

Tournefortia

ARBO/LIANA

$\mathrm{VA} / \mathrm{MO}$

Boraginaceae

HERB

Brassicaceae

Polyctenium

HERB

Physaria

HERB

Brassicaceae

HERB

VA

Bromeliaceae

Puya?

HERB

Epiphyta

Bromeliaceae

HERB

Epiphyta

\section{Burseraceae}

Protium

ARBO

TF*/VA/CA/CE 
Trattinnickia

Burseraceae

\section{Cannabaceae}

Celtis

\section{Caprifoliaceae}

Caprifoliaceae

\section{Caryophyllaceae}

Caryophyllaceae

\section{Celastraceae}

Cheiloclinium

Hippocratea

Maytenus

Tontelea

Celastraceae

\section{Chloranthaceae}

Hedyosmum

Chrysobalanaceae

Exellodendron

Licania

\section{Clusiaceae}

Symphonia

Convolvulaceae

Evolvulos

Dicranostyles

Ipomoea

Convolvulaceae

\section{Cucurbitaceae}

Cayaponia

Cucurbita

\section{Cunoniaceae}

Cunoniaceae

ARBO

$\mathrm{ARBO}$

VA

TF*/VA/CA/CE

ARBO

TF*/VA/CE

HERB

Dry/CE

HERB

HERB

TF

HERB

HERB

TF

HERB

TF

ARBO

\section{Cyperaceae}

Cyperaceae

HERB

$\mathrm{VA}^{*}$

\section{Dilleniaceae}


Davilla

Tetracera

Elaeocarpaceae

Sloanea

Elaeocarpaceae

Ericaceae

Gaylussacia

Ericaceae

\section{Euphorbiaceae}

Acalypha

Alchornea

Bernardia

Chamaesyce

Croton

Dalechampia

Euphorbia

Pera

Maprounea

Micrandra

Sapium

\section{Fabaceae}

Caesalpinioideae

Bauhinia

Cassia

Cenostigma

Copaifera

Crudia

Dicorynia

Eperua

Macrolobium

Parkinsonia

Phanera

Tachigali
ARBO/LIANA

ARBO/LIANA

ARBO

ARBO

VA/TF/CA

VA

ARBO

MO

ARBO

$\mathrm{MO}$

VA

$\mathrm{VA}^{*} / \mathrm{TF}$

ARBO

VA/TF

ARBO

$\mathrm{VA}^{*}$

HERB

VA/TF

ARBO/LIANA

VA

HERB

$V A^{*}$

ARBO

VA/CA/TF

ARBO

TF

ARBO

TF/CA

ARBO

$\mathrm{VA}^{*} / \mathrm{TF}$

$\begin{array}{ll}\text { ARBO/LIANA } & \text { VA/TF } \\ \text { ARBO } & \text { VA/Dry - savanna } \\ \text { ARBO } & \text { TF* }^{*} \\ \text { ARBO } & \text { VA - open } \\ \text { ARBO } & \text { VA/CA } \\ \text { ARBO } & \text { TF*/VA } \\ \text { ARBO } & \text { TF/VA } \\ \text { ARBO } & \text { VA/CA/TF } \\ \text { ARBO } & \text { Dry }{ }^{*}-\text { savanna/TF } \\ \text { ARBO } & \text { TF*/VA } \\ \text { ARBO } & \text { VA/TF/CA/CE }\end{array}$


Mimosoideae

Acacia

Anadenanthera

Calliandra

Dinizia

Havardia

Mimosa

Parkia

Piptadenia

Schrankia

Stryphnodendron

Mimosoideae

Papilionoideae

Bowdichia

ARBO

Dry* - savanna/TF

Camptosema

Canavalia

HERB

TF

ARBO

$\mathrm{TF}^{\star}$ - open

Dalbergia

ARBO

VA - open/TF

Dipteryx

ARBO

$\mathrm{VA} / \mathrm{TF}$

Dioclea

ARBO

VA/TF

Galactia

ARBO

$\mathrm{TF}^{\star}$ - open

Lecointea

ARBO

VA

Lonchocarpus

ARBO

VA

Machaerium

ARBO/LIANA

VA/TF

Piscidia

Platymiscium

Pterocarpus

Pueraria

Zollernia

ARBO

ARBO

VA/TF

ARBO

VA

HERB

TF

ARBO

VA/TF

\section{Gentianaceae}

Gentianaceae

HERB

\section{Lamiaceae}

Aegiphila

ARBO

VA/Dry - savanna

Asterohyptis

HERB

VA

Hyptis

HERB

$\mathrm{VA}^{*}$

Lamiaceae

HERB 


\section{Lecythidaceae}

Eschweilera

Lecythidaceae

\section{Lentibulariaceae}

Lentibulariaceae

\section{Loasaceae}

Mentzelia?

\section{Loranthaceae}

Cladocolea

Struthanthus

Loranthaceae

\section{Malpighiaceae}

Banisteriopsis

Bunchosia

Byrsonima

Janusia

Tetrapterys

Malpighiaceae

Malvaceae

Ayenia/Byttneria

Luehea

Guazuma

Heliocarpus

Mollia

Pseudobombax

Scleronema

Theobroma

Melastomataceae/ Combretaceae

Melastomataceae/Combretaceae

Meliaceae

Cedrela

Guarea

Meliaceae

Trichilia
ARBO

VA/TF

ARBO

VA/TF

AQ.HERB

VA

HERB

Dry/MO

ARBO

TF

ARBO

$\mathrm{TF}^{*} / \mathrm{VA}$

ARBO

LIANA

$\mathrm{TF}$

ARBO

ARBO/LIANA

Dry $^{*}$ - savanna/TF/VA

HERB

Dry/CE

ARBO

TF/VA/Dry

HERB

HERB

Dry/VA

ARBO

VA

ARBO

VA

ARBO

TF

ARBO

VA*/TF/CA/BW*

ARBO

$\mathrm{VA}^{*} / \mathrm{TF}$

ARBO

TF

ARBO

TF/VA

ARBO

VA/TF

ARBO

$\mathrm{TF}^{\star} / \mathrm{VA}$

ARBO

TF/VA

ARBO

TF/VA

ARBO 
Moraceae/Urticaceae

Moraceae/Urticaceae

ARBO

$\mathrm{TF}^{*} / \mathrm{VA}$

Muntingiaceae

Muntingia

ARBO

VA

Myricaceae

Myrica

ARBO

$\mathrm{MO}$

Myricaceae

ARBO

VA/TF

Myristicaceae

Virola

ARBO

$\mathrm{VA}^{*} / \mathrm{TF}$

Myrtaceae

Myrtaceae

ARBO

VA/TF

Ochnaceae

Ouratea

ARBO

VA/TF

Ochnaceae

Ochnaceae

ARBO

TF

Olacaceae

Chaunochiton

ARBO

TF

Dulacia

ARBO

VA

Olacaceae

ARBO

TF

Onagraceae

Onagraceae

HERB

$\mathrm{VA}^{*}$

Passifloraceae

Turnera

HERB

TF/VA

Phyllanthaceae

Amanoa

ARBO

$\mathrm{VA}^{*} / \mathrm{CA}$

Hieronyma

HERB

$\mathrm{TF}^{\star}$

Phyllanthus

HERB

$\mathrm{TF}^{\star}$

Phytolaccaceae

Microtea

HERB

VA

Picrodendraceae

Piranhea

ARBO

$\mathrm{VA}^{*}$

Piperaceae

Piper

ARBO

VA 
Plantaginaceae

Sairocarpus?

ARBO

Poaceae

Poaceae

HERB

$\mathrm{VA} / \mathrm{TF}$

Podocarpaceae

Podocarpus

ARBO

$\mathrm{MO}$

Polemoniaceae

Leptodactylon?

HERB

Polemoniaceae

HERB

Polygalaceae

Badiera

ARBO

Securidaca

ARBO

VA/TF

Polygalaceae

HERB

Polygonaceae

Polygonum

HERB

$V A^{*}$

Symmeria

ARBO

$\mathrm{VA}^{*}$

Triplaris

ARBO

VA

Pontederiaceae

Pontederiaceae

AQVP

VA

Primulaceae

Anagallis??

HERB

Myrsine

ARBO

MO

Proteaceae

Euplassa

ARBO

TF

Panopsis

ARBO

VA

Roupala

ARBO

VA/Dry* - savanna

Proteaceae

ARBO

Ranunculaceae

Hamadryas??

HERB

Rhamnaceae

Rhamnaceae

ARBO

Rhizophoraceae

Rhizophora

MANG

Rubiaceae 
Alseis

Alibertia

Antirhea

Borreria

Bothriospora

Chiococca

Chomelia

Duroia

Faramea

Ferdinandusa

Genipa

Hedyotis

Houstonia??

Stachyarrhena

Rubiaceae

Rutaceae

Citrus

Esenbeckia

Zanthoxylum

Rutaceae

\section{Salicaceae}

Homalium

Neosprucea

Salix

Xylosma/Banara

Salicaceae

Salviniaceae

Azolla AQVP VA

\section{Sapindaceae}

Cupania

Paullinia

Serjania

Sapindaceae
ARBO

ARBO

ARBO

HERB

ARBO

ARBO

ARBO

ARBO

ARBO

ARBO

ARBO

ARBO

HERB

ARBO

TF

ARBO

ARBO

ARBO

ARBO

TF

TF

VA/TF/Dry - savanna

$\mathrm{VA}^{*}$

VA

CE

VA/TF/Dry - savanna

$\mathrm{VA}^{*} / \mathrm{TF} / \mathrm{CA} / \mathrm{BW}^{*}$

TF/VA

VA/TF

VA/Dry - savanna

VA

ARBO

ARBO

ARBO

ARBO

ARBO

ARBO
VA

$\mathrm{MO}$

VA

VA

TF

CE

VA/TF

VA/TF

Sapotaceae

ARBO

VA/TF/Dry - savanna

ARBO/Liana

VA

ARBO/Liana

ARBO 
Diploon

Manilkara

Micropholis

Pouteria

Sapotaceae

\section{Scrophulariaceae}

Aragoa

Solanaceae

Capsicum

Cestrum

Solanum

Solanaceae

\section{Thymelaeaceae}

Daphnopsis

Urticaceae

Cecropia

Verbenaceae

Citharexylum

Lantana-type

Phyla

Vochysiaceae

Vochysia

\section{Unknown}

c3p3 triang 1416
ARBO

ARBO

ARBO

ARBO

ARBO

HERB

HERB

ARBO

HERB

HERB

ARBO

ARBO

ARBO

HERB

HERB

ARBO
$\mathrm{MO}$

Dry* - savanna/TF

$\mathrm{VA}^{*} / \mathrm{TF}$

TF/CA/Dry - Savanna

VA/TF/CA

VA/TF

VA*/TF/CE

TF/VA

TF

VA/MO

TF/VA

TF/CE - ecotone

VA/Dry - savanna

VA 
APPENDIX 2

Pollen Plates 
Plate I - Amaranthaceae

Plate II - Apiaceae, Aquifoliaceae

Plate III - Anacardiaceae

Plate VI - Araliaceae, Araceae, Arecaceae

Plate $\mathrm{V}$ - Arecaceae

Plate $\mathrm{VI}$ - Asteraceae

Plate VII - Begoniaceae, Betulaceae, Bignoniaceae

Plate VIII - Boraginaceae, Brassicaceae

Plate IX - Bromeliaceae, Burseraceae

Plate X - Cannabaceae, Caprifoliaceae, Celastraceae

Plate XI - Celastraceae, Chloranthaceae

Plate XII - Chrysobalanaceae, Clusiaceae

Plate XIII - Convolvulaceae

Plate XIV - Curcubitaceae, Cunoniaceae, Cyperaceae

Plate XV - Dilleniaceae, Eleocarpaceae, Ericaceae

Plate XVI - Euphorbiaceae

Plate XVII - Euphorbiaceae

Plate XVIII - Fabaceae (Caesalpinioideae)

Plate XIX - Fabaceae (Caesalpinioideae)

Plate XX - Fabaceae (Caesalpinioideae, Mimosoideae)

Plate XXI - Fabaceae (Mimosoideae)

Plate XXII - Fabaceae (Mimosoideae, Papilionoideae)

Plate XXIII - Fabaceae (Papilionoideae)

Plate XXIV - Fabaceae (Papilionoideae), Lamiaceae, Lecythidaceae

Plate XXV - Lentibulariaceae, Loasaceae, Loranthaceae

Plate XXVI - Malpighiaceae

Plate XXVII - Malvaceae

Plate XXVIII - Malvaceae

Plate XXIX - Moraceae, Muntigiaceae, Myiricaceae, Myristicaceae

Plate XXX - Myrtaceae, Ochnaceae, Olacaceae

Plate XXXI - Onagraceae, Passifloraceae, Phyllanthaceae

Plate XXXII - Phytolaccaceae, Picrodendraceae, Piperaceae, Plantaginaceae

Plate XXXIII - Podocarpaceae, Polemoniaceae, Polygalaceae

Plate XXXIV - Polygonaceae, Pontederidaceae, Primulaceae

Plate XXXV - Proteaceae, Rhammanaceae, Rubiaceae

Plate XXXVI - Rubiaceae

Plate XXXVII - Rubiaceae

Plate XXXVIII - Rubiaceae, Rutaceae

Plate XXXIX - Salicaceae, Salviniaceae

Plate XL - Sapindaceae, Sapotaceae

Plate XLI - Solanaceae, Urticaceae

Plate XLII - Verbenaceae, Acritarchs, Grimsdalea.

All Scale bars $=10 \mu \mathrm{m}$ 
Amaranthaceae

Plate I
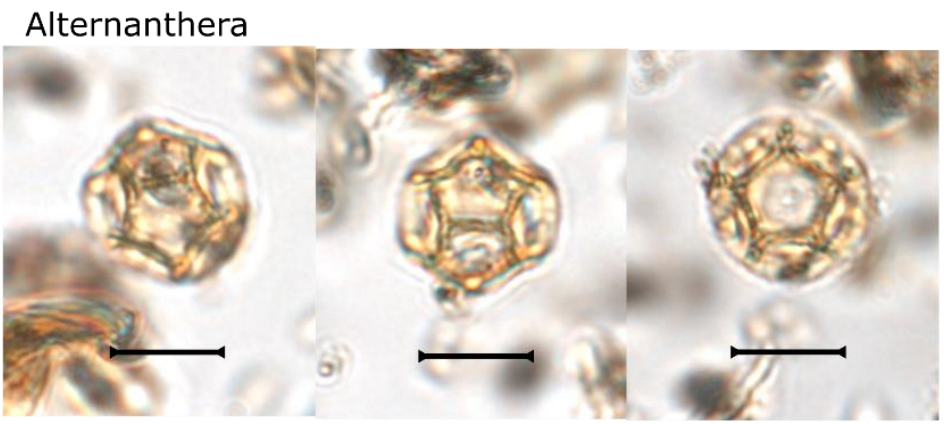

Chenopodium

\section{Amaranthus}

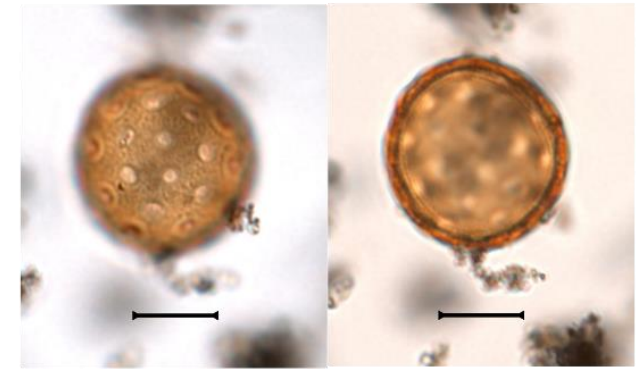

Gomphrena

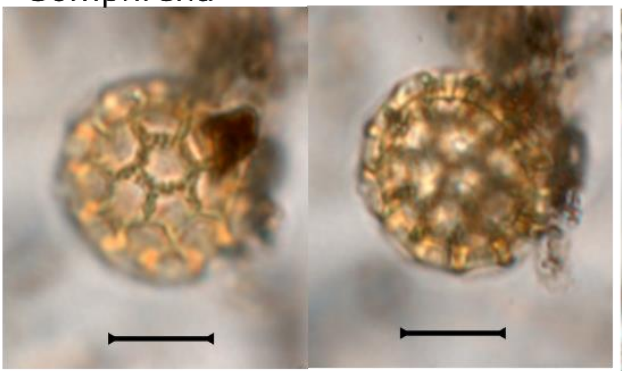

\section{Chamissoa}

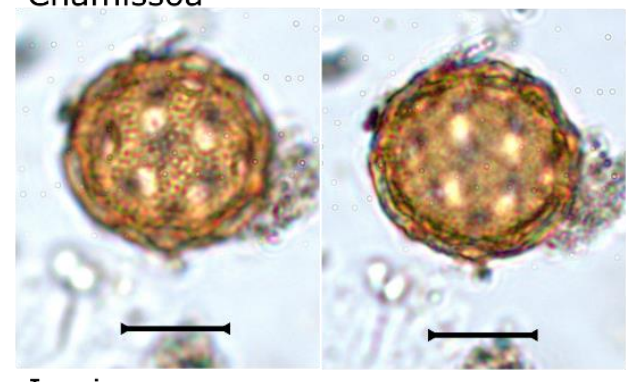

Iresine

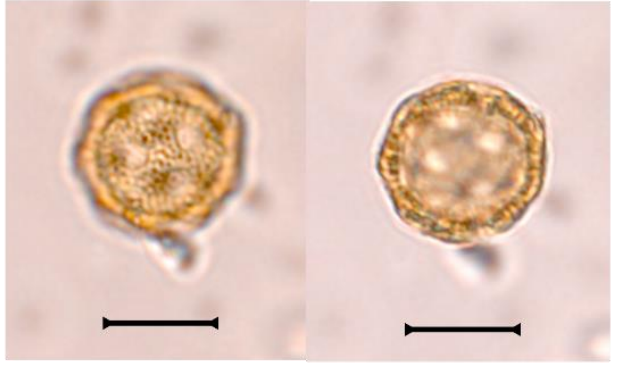

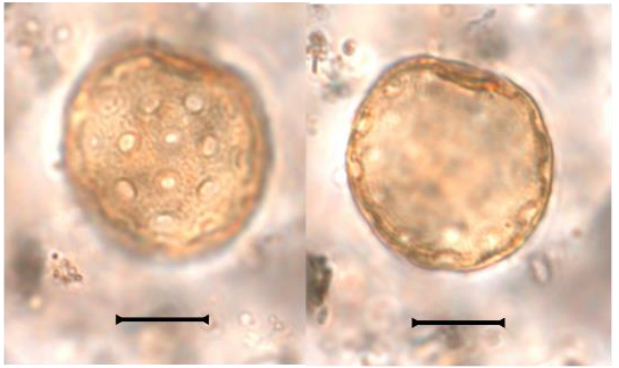
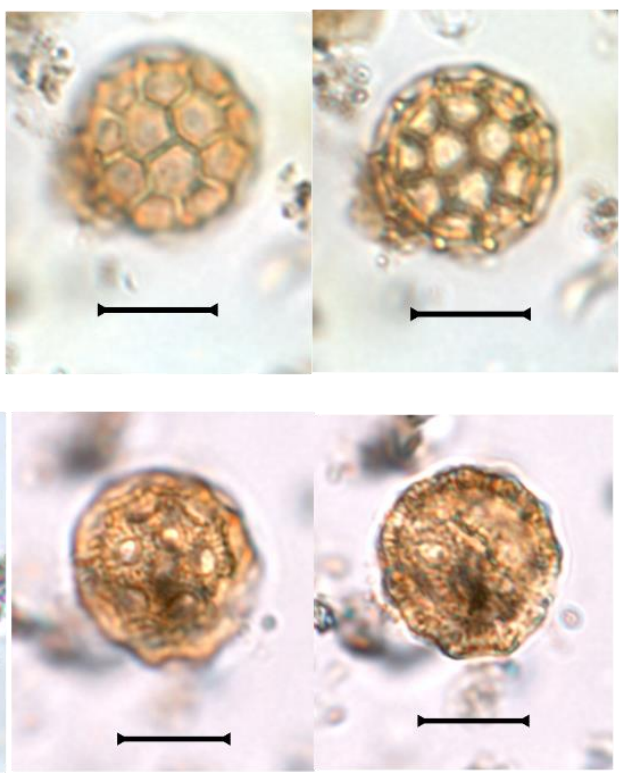
Irenella
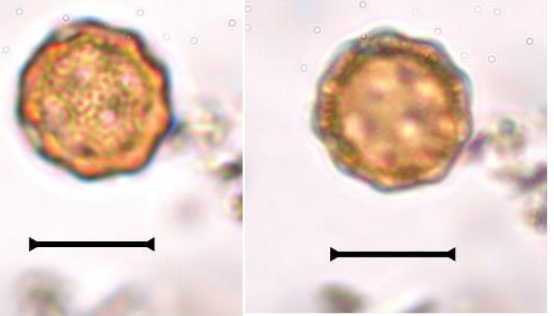

Amaranthaceae 1

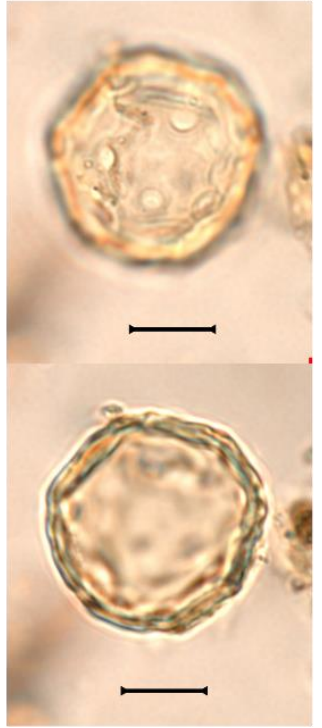

Amaranthaceae 2

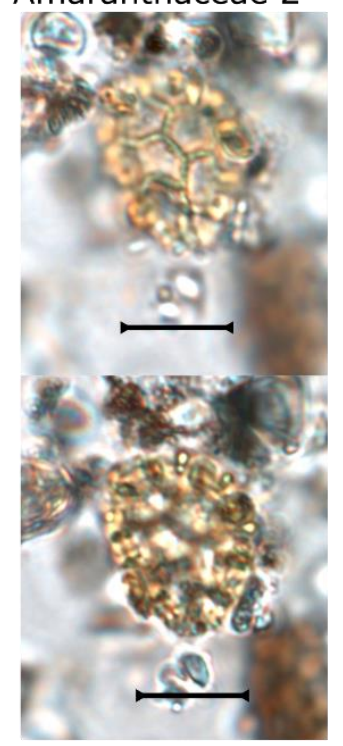


Apiaceae

Plate II

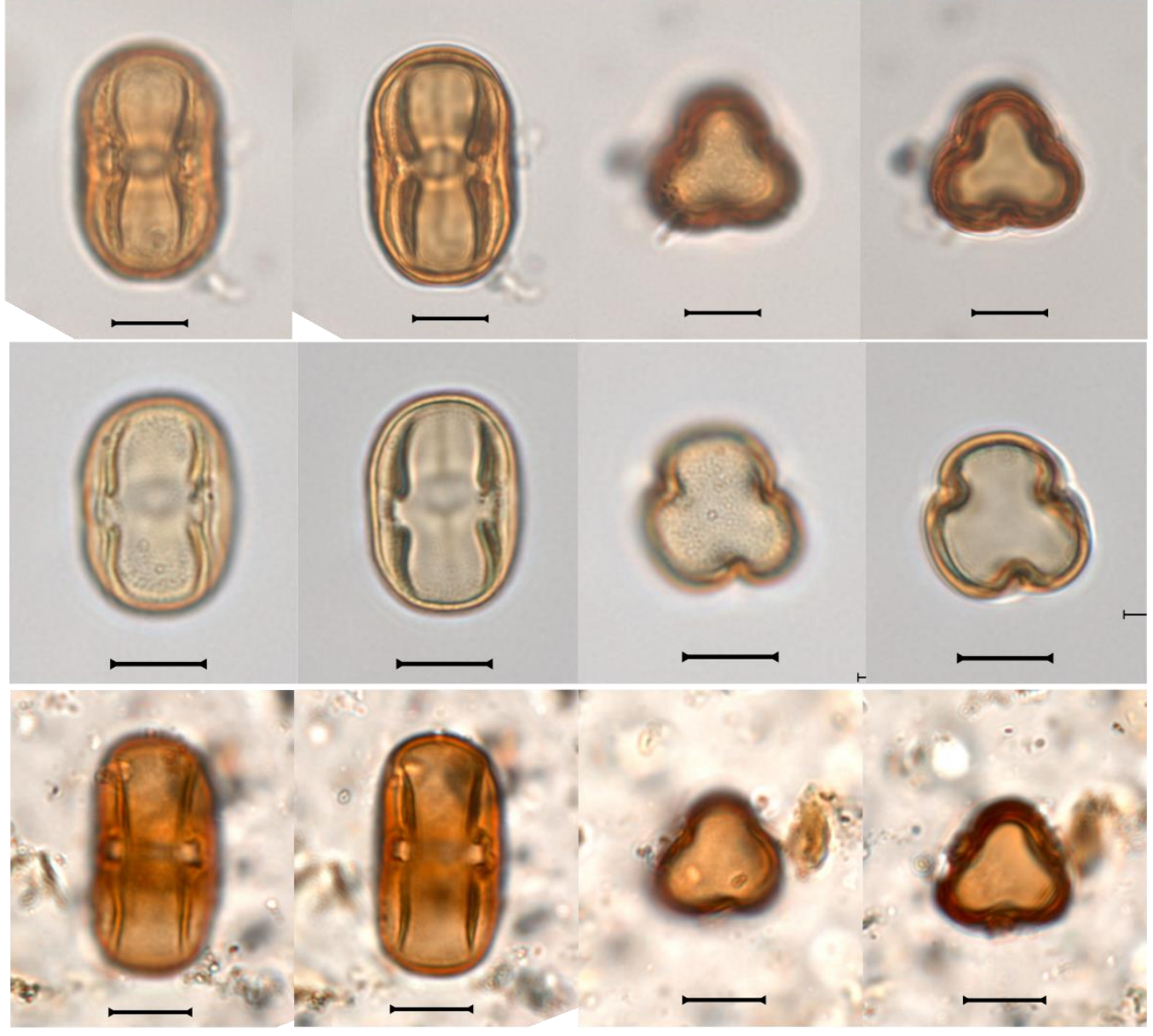

Aquifoliaceae Ilex

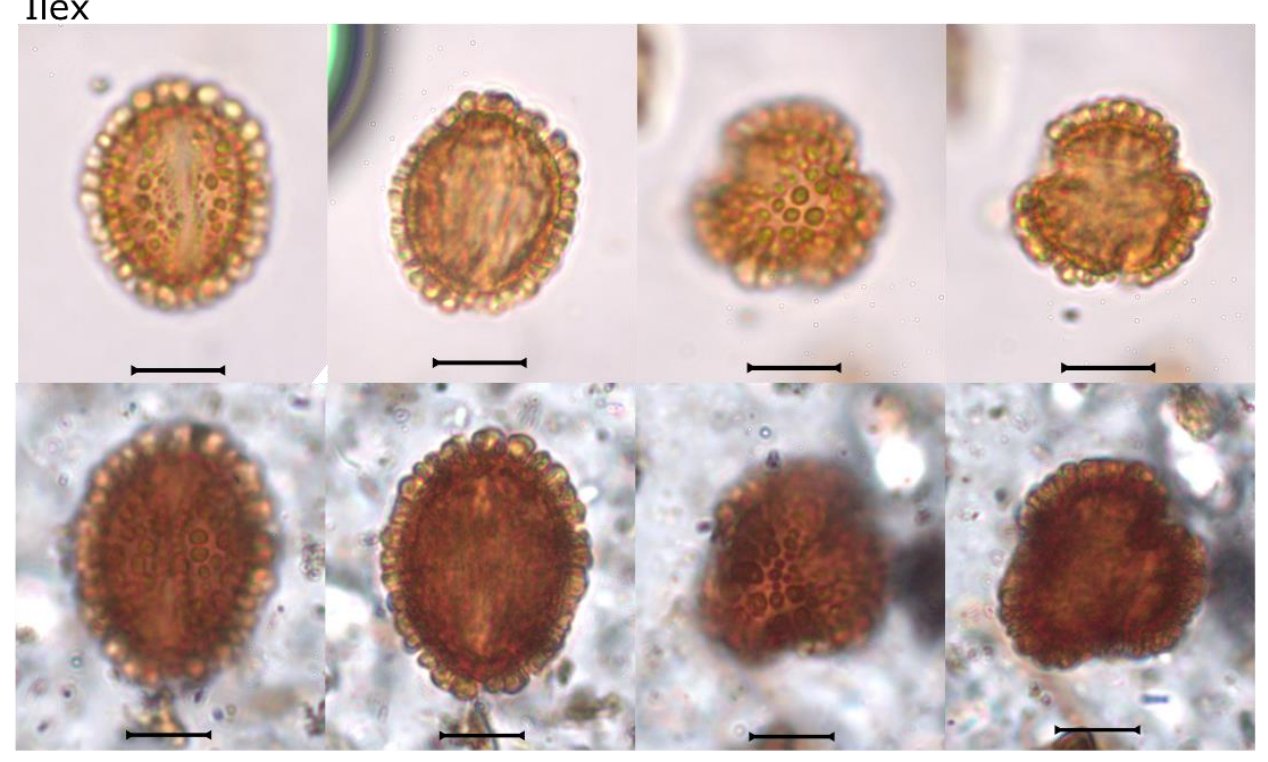


Anacardiaceae

Plate III

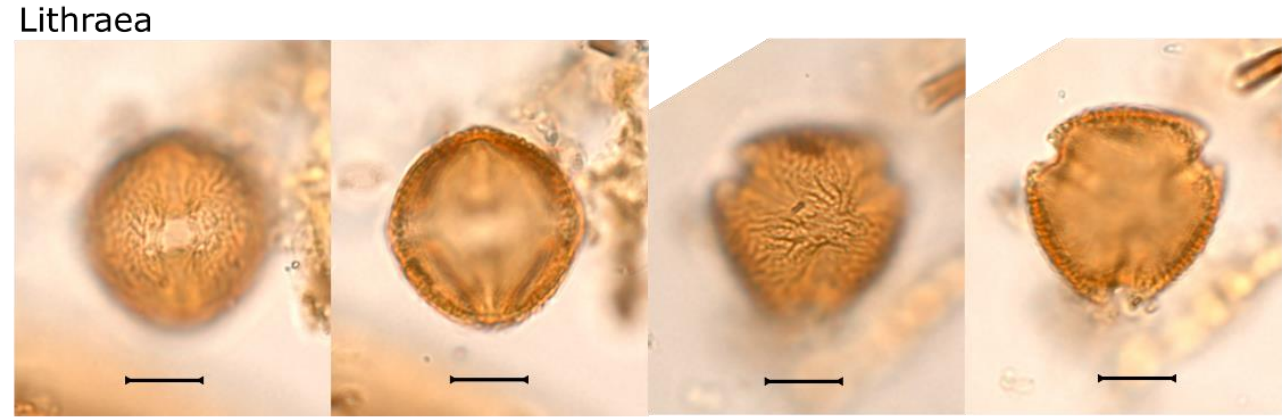

Tapirira
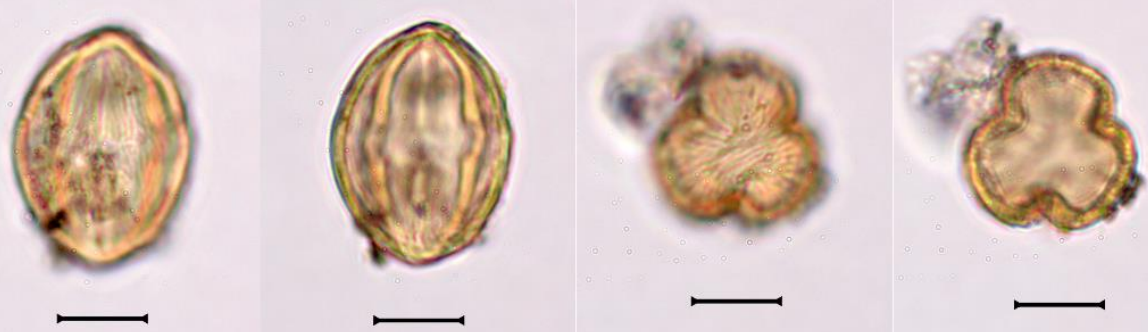

\section{Spondias}

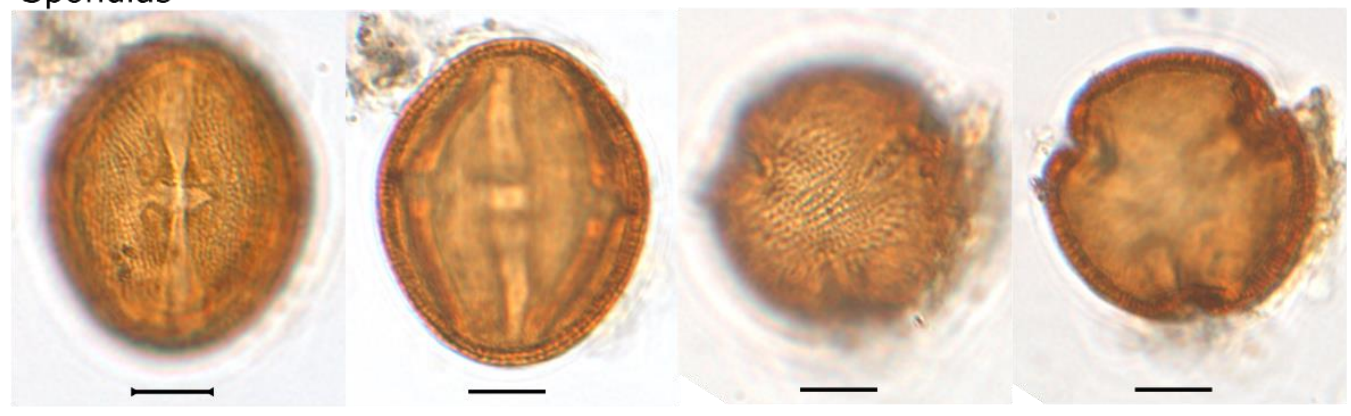

\section{Anacardiaceae}
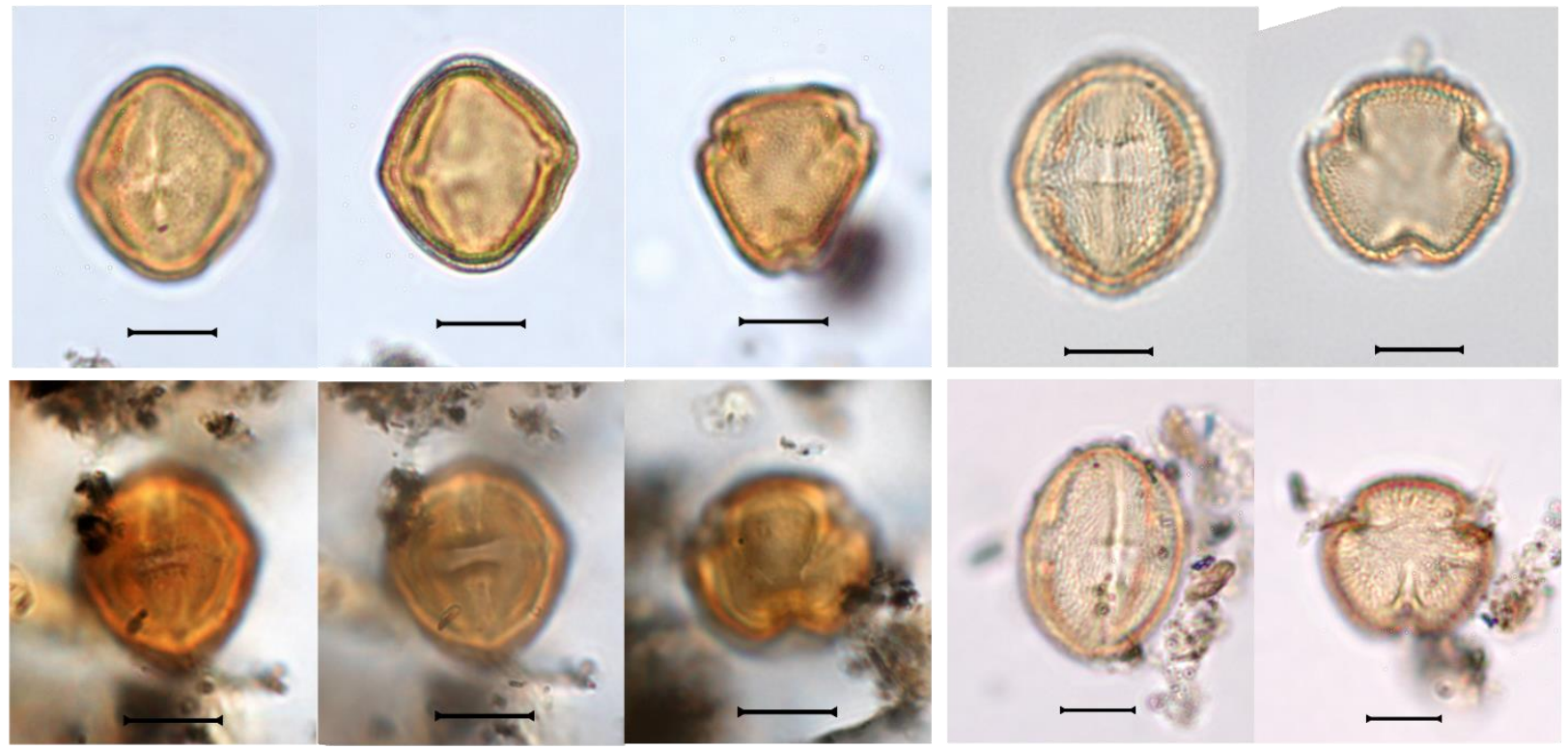


\section{Araliaceae}

Plate IV
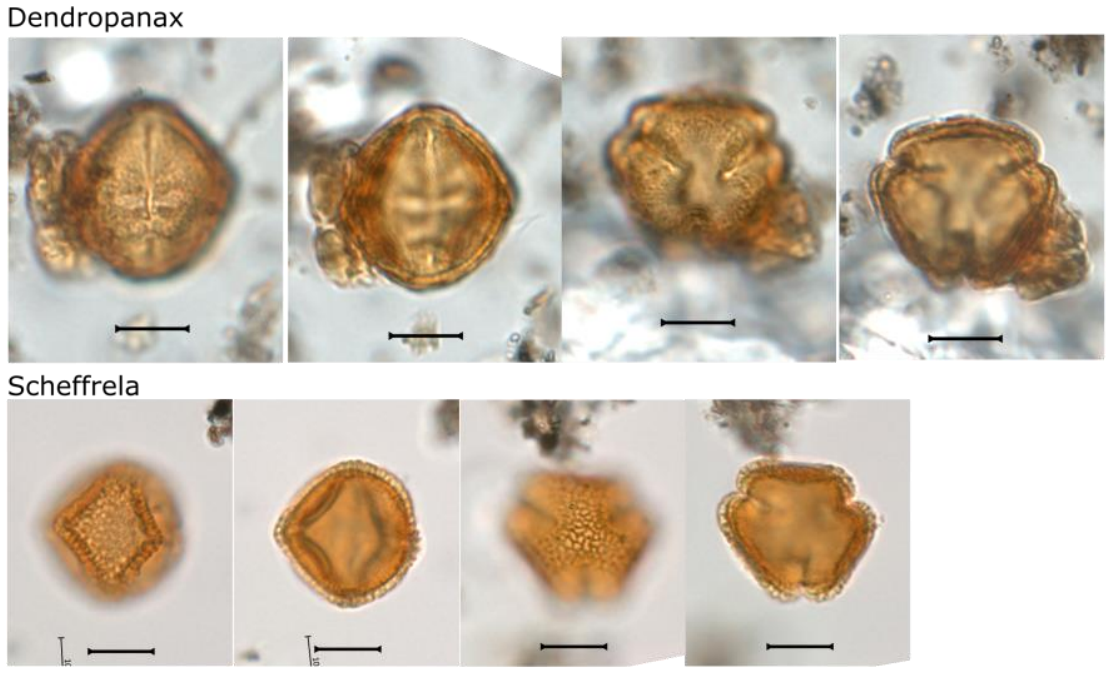

\section{Araceae}

Spathiphyllum

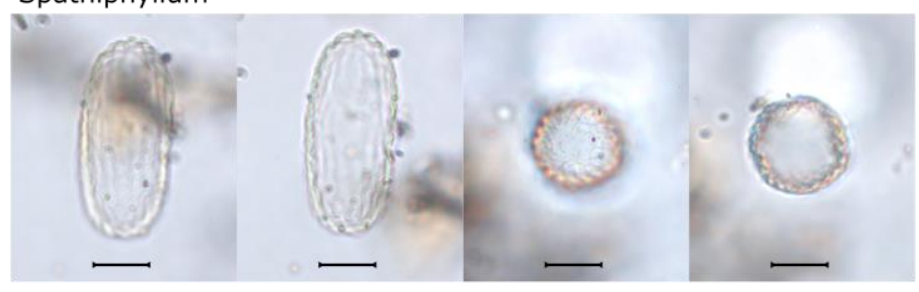

\section{Arecaceae}

Astrocaryum

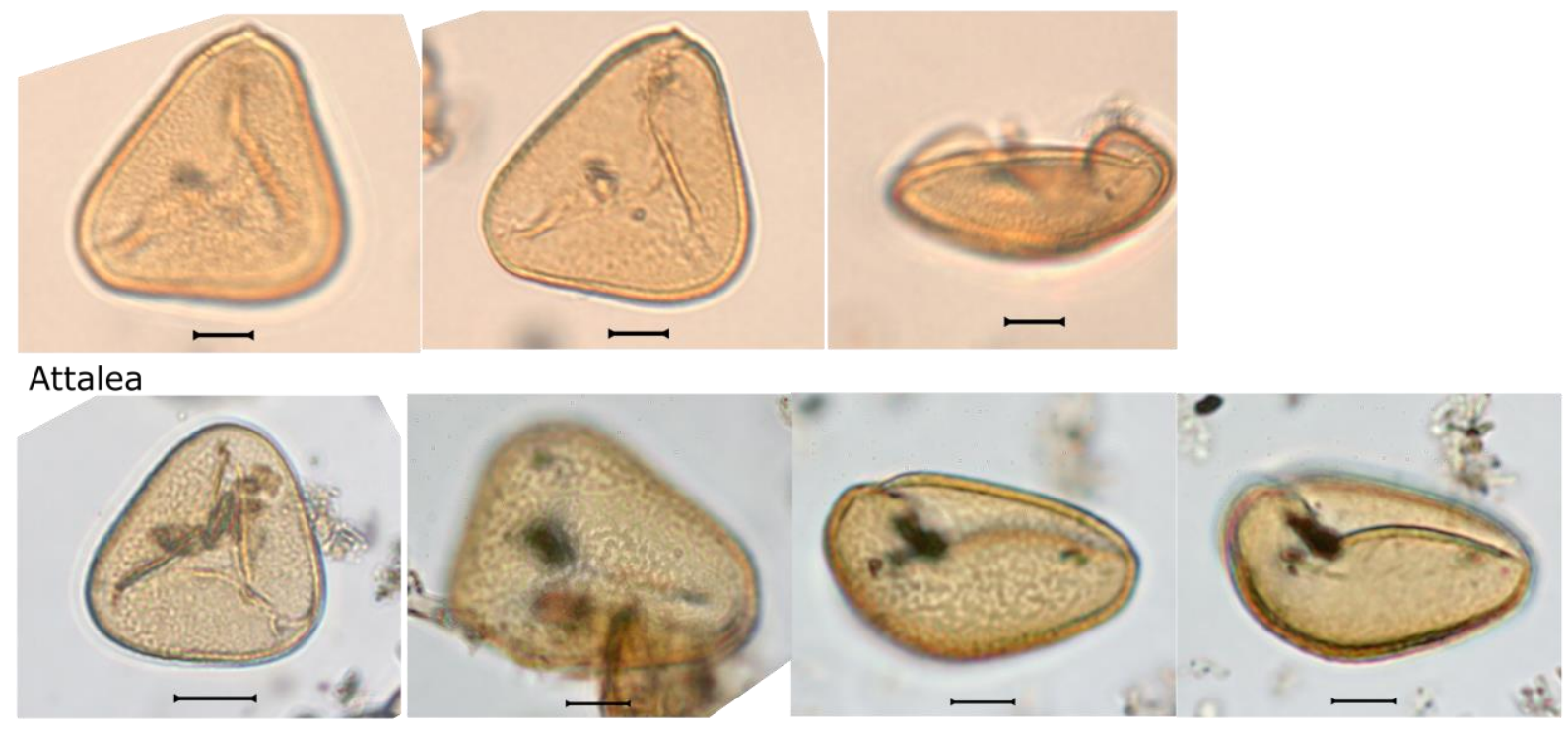




\section{Arecaceae}

Plate V

Attalea cf. humilis
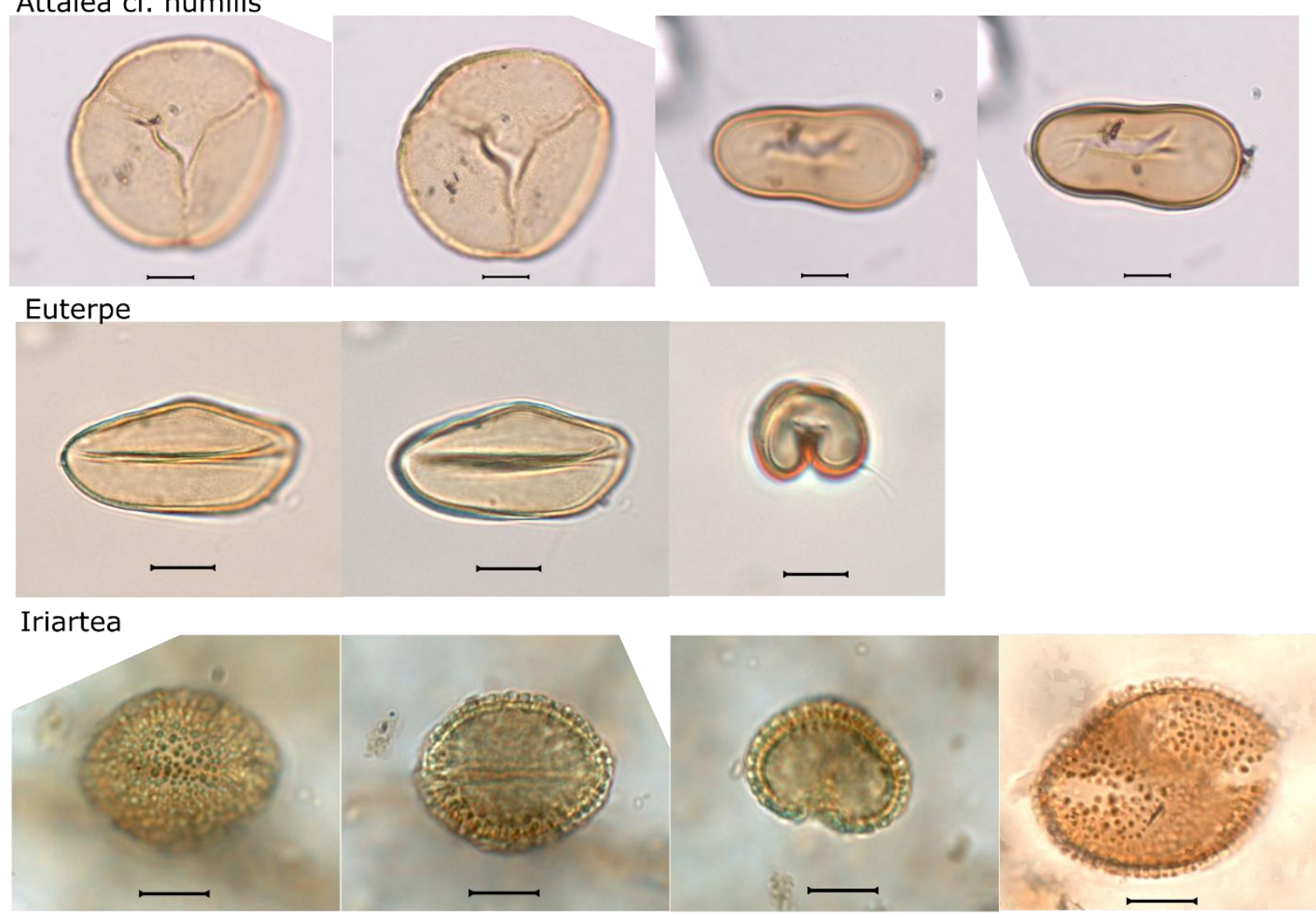

\section{Mauritia}

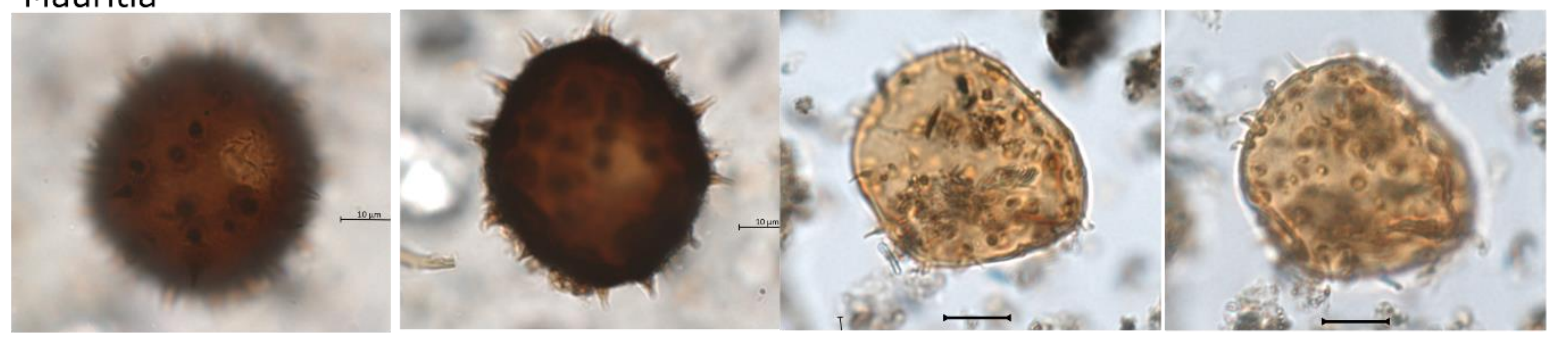

\section{Elaeis}
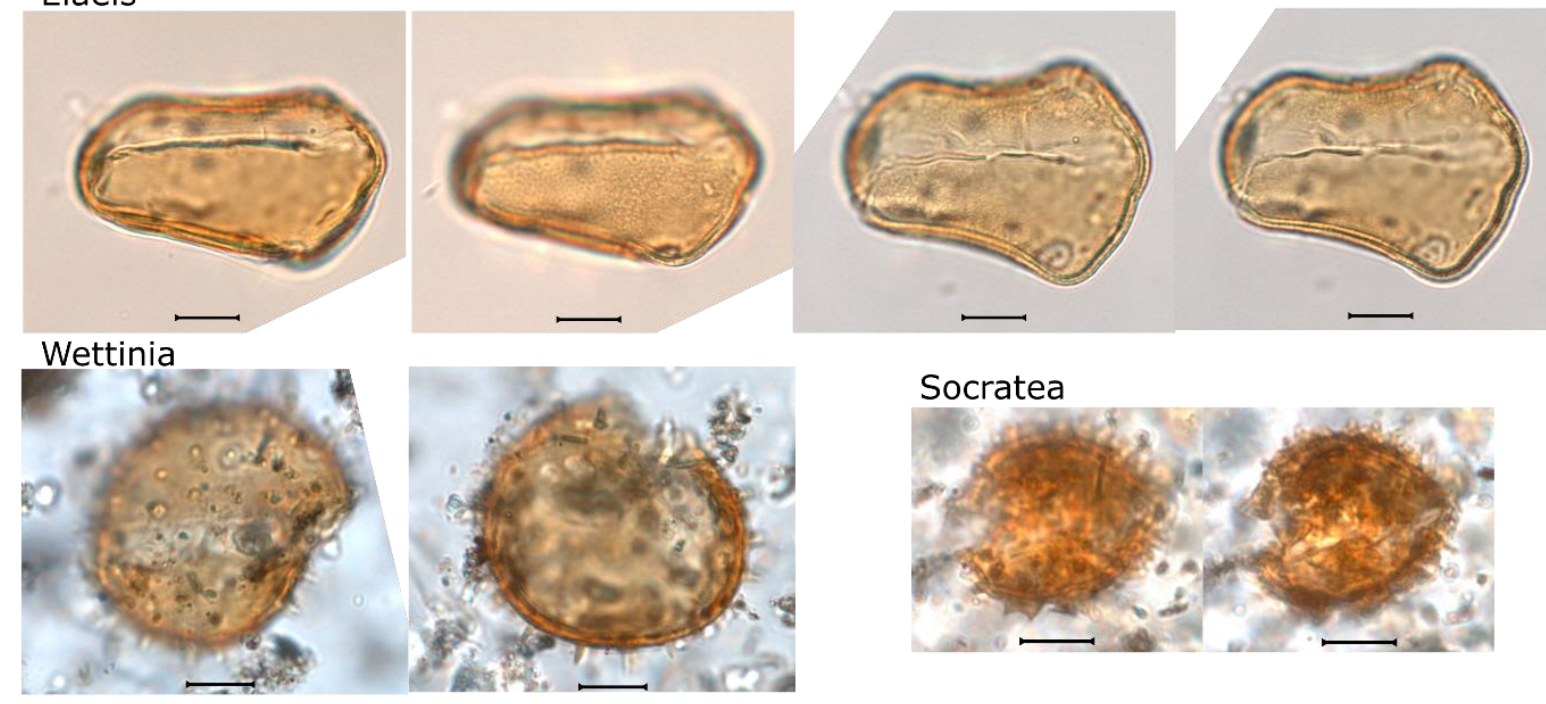

\section{Socratea}

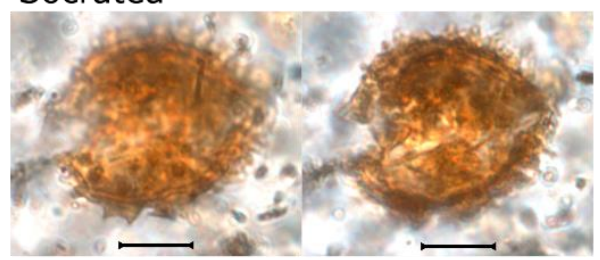




\section{Asteraceae}

\section{Plate VI}

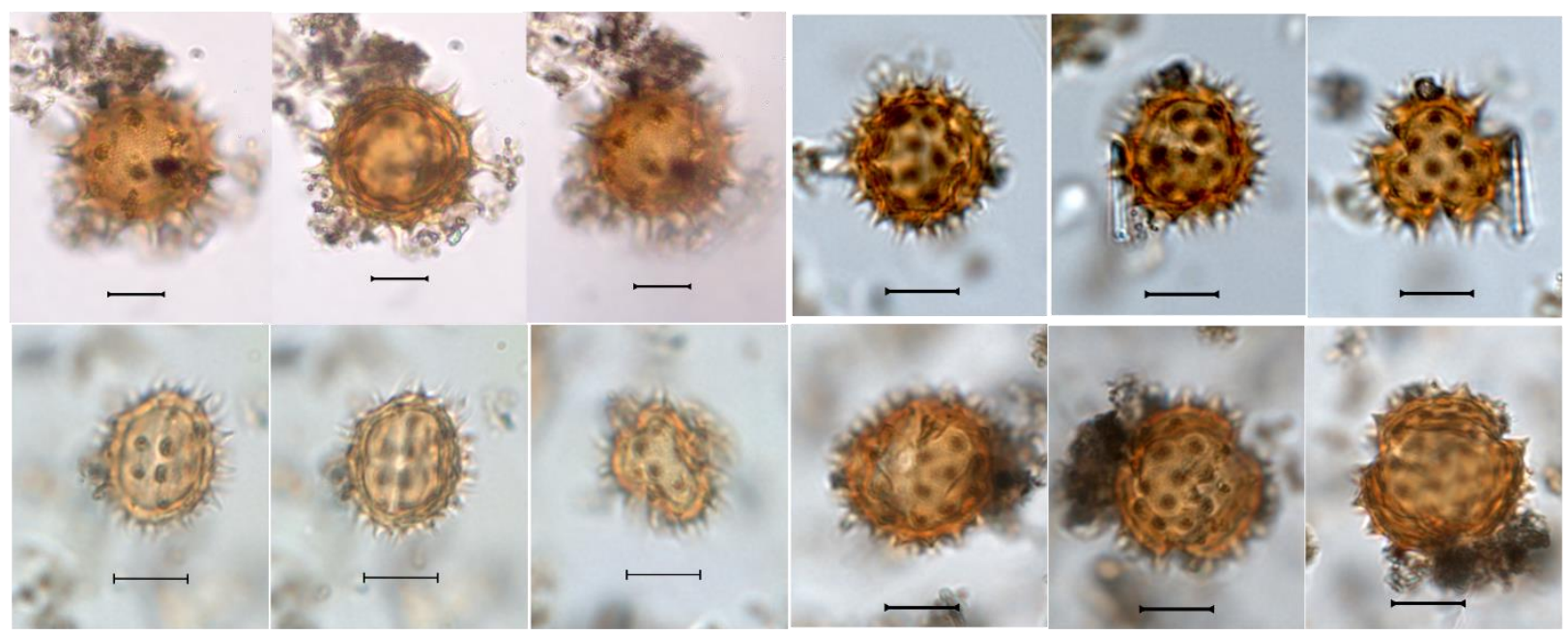

Ambrosia

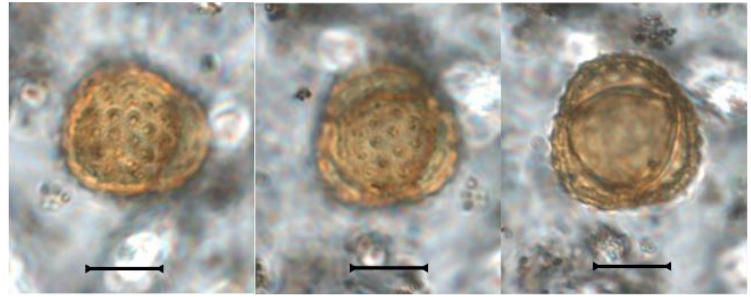

Asteraceae (Liguliflorae)

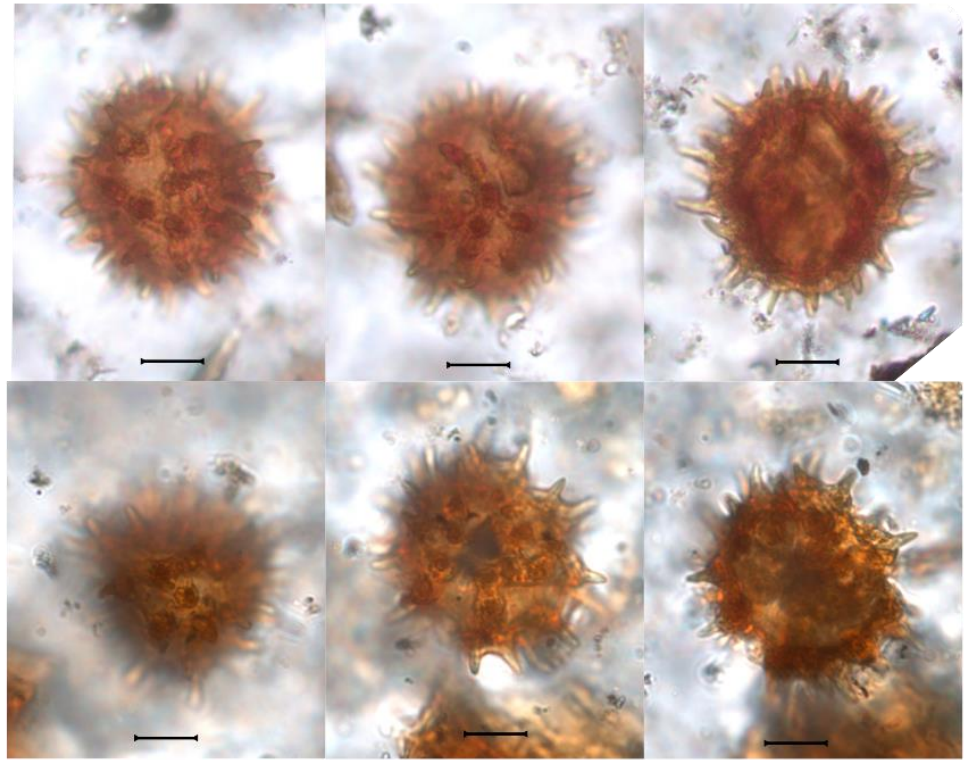

\section{Elephantopus}

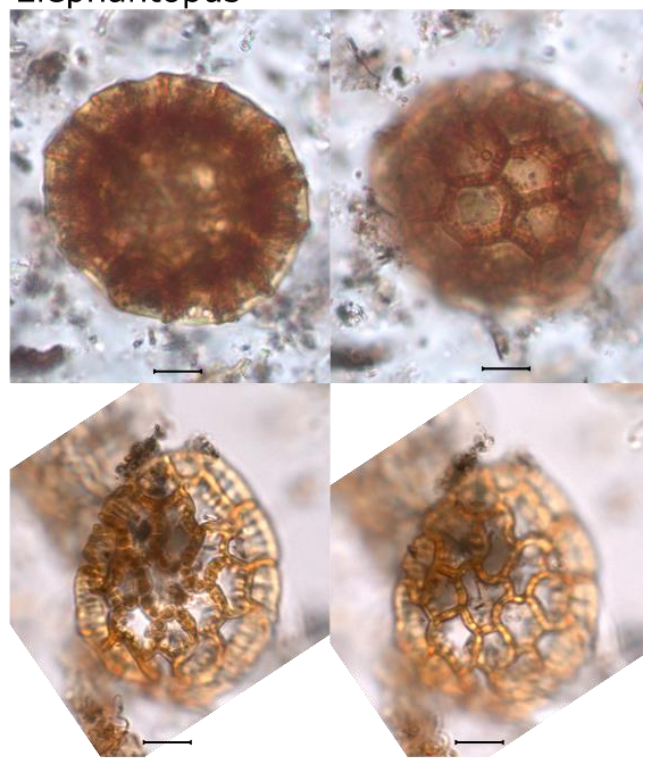




\section{Plate VII}

\section{Begoniaceae}

Begonia

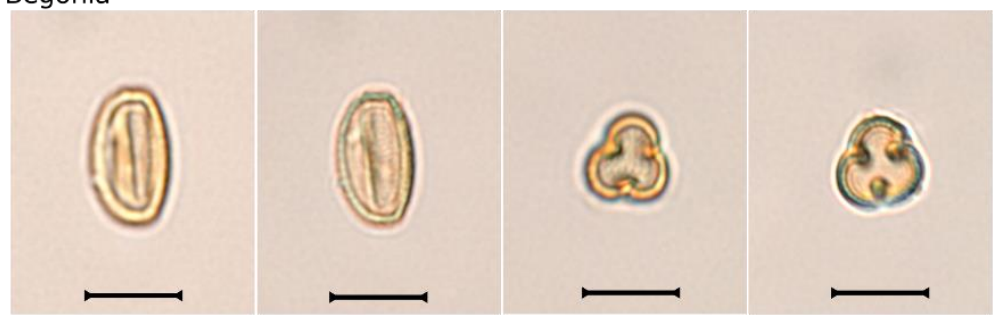

Betulaceae

Alnus

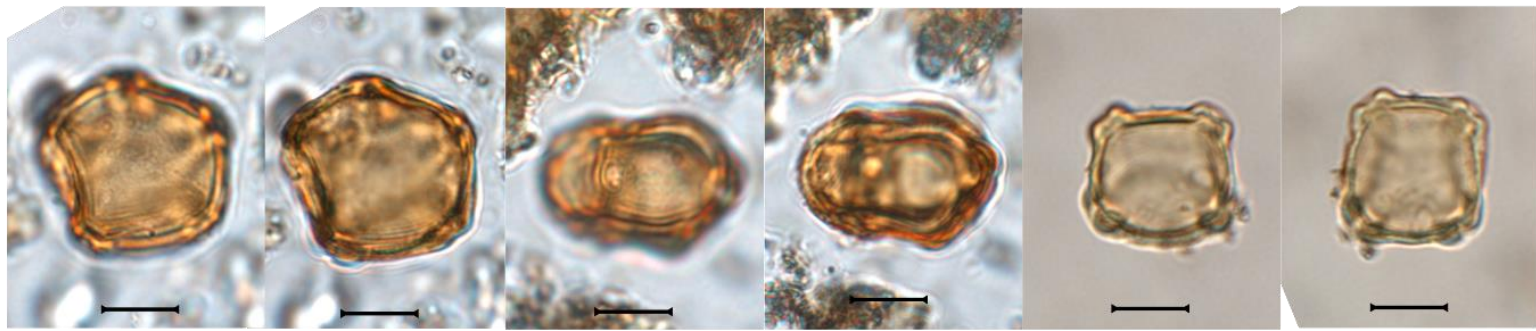

\section{Bignoniaceae}

Spathodea
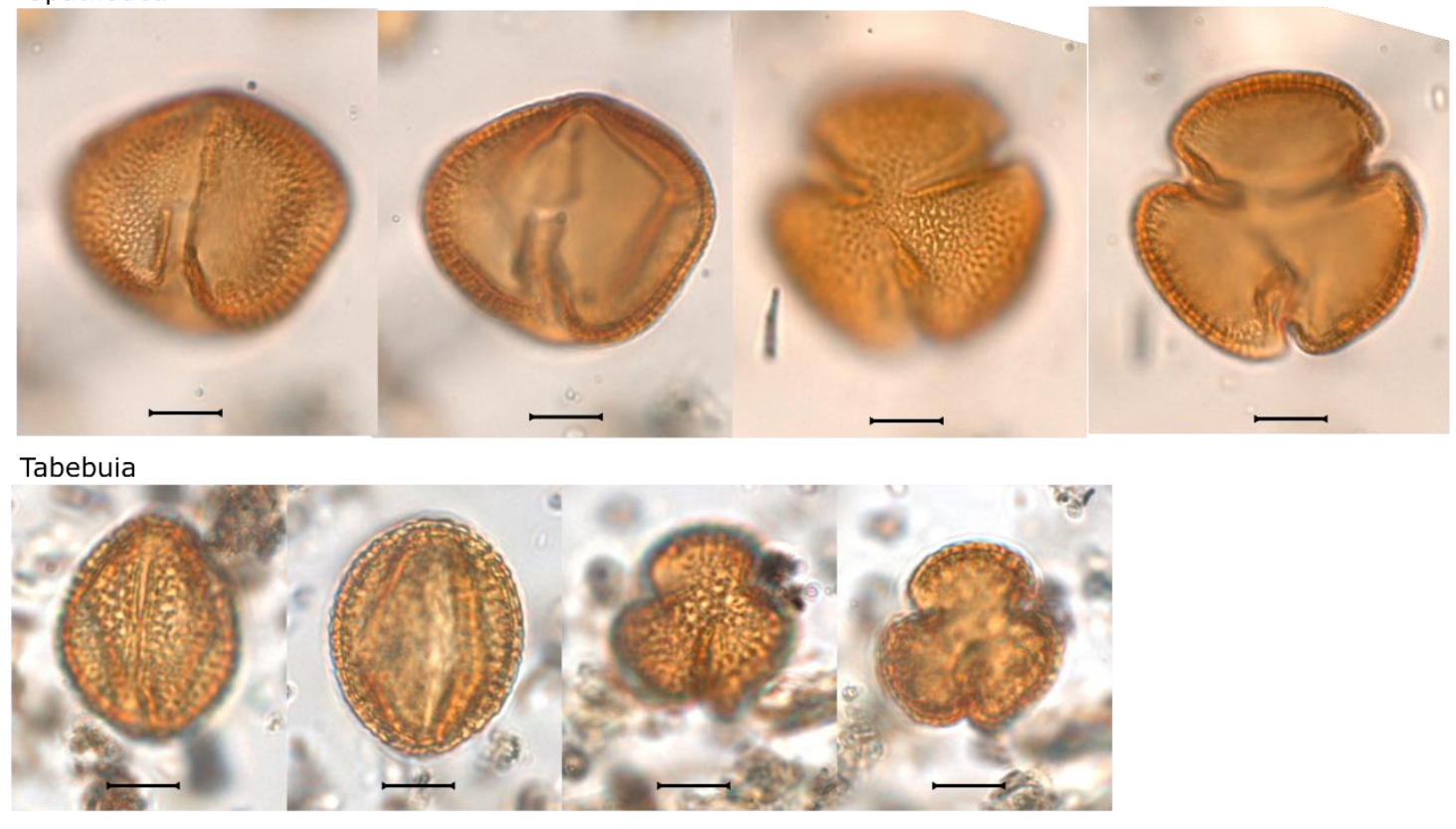

Tecoma

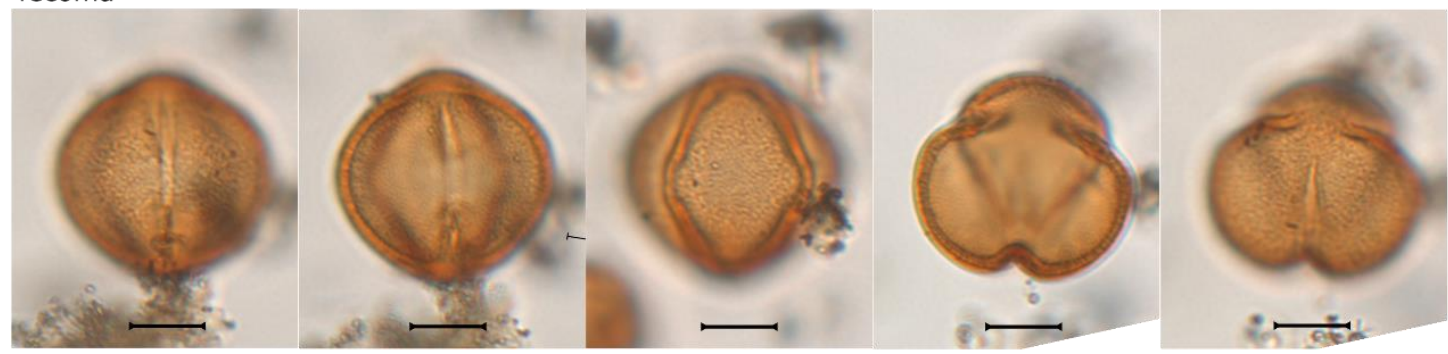




\section{Boraginaceae}

Plate VIII

Tournefortia
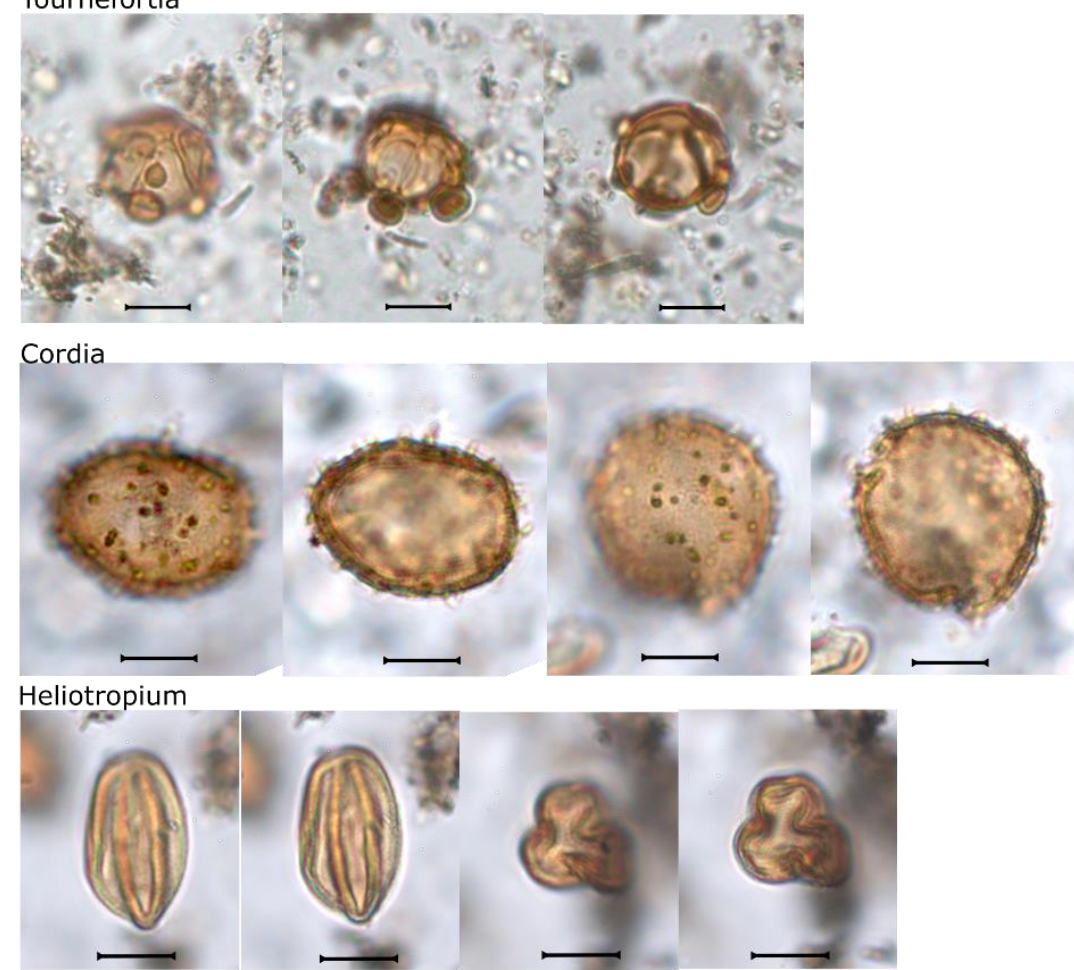

Boraginaceae

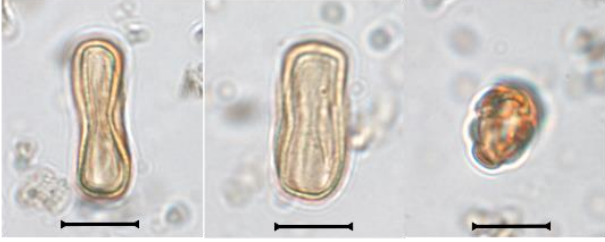

Brassicaceae

Physaria

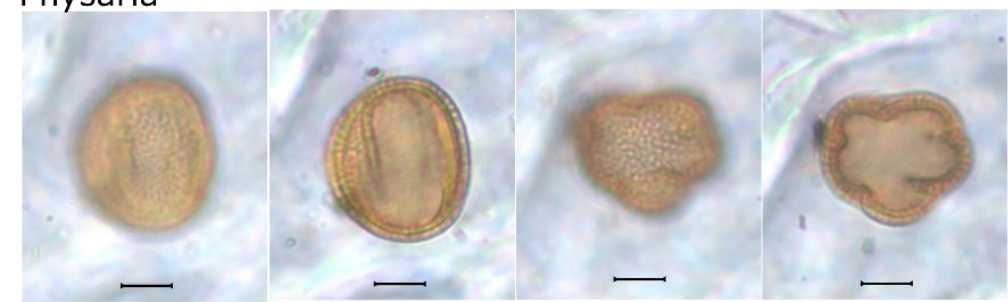

Brassicaceae

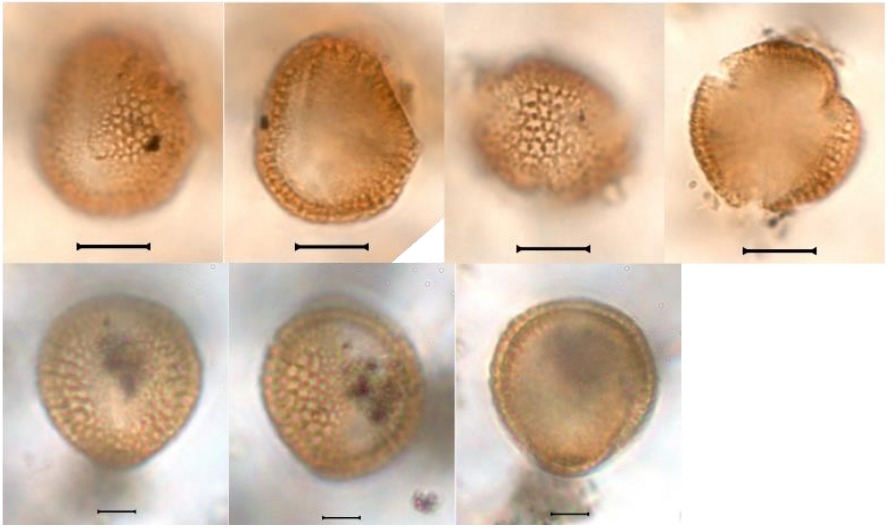


Bromeliaceae

Plate IX

Puya

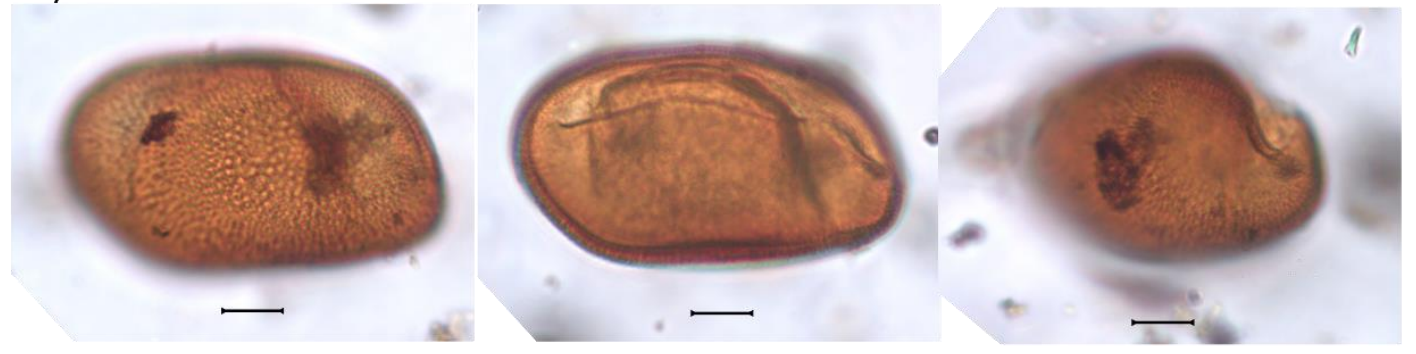

Bromeliaceae

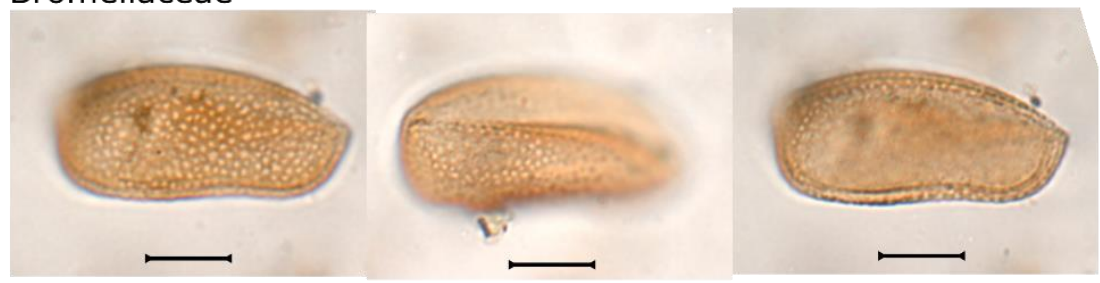

Burseraceae

Protium
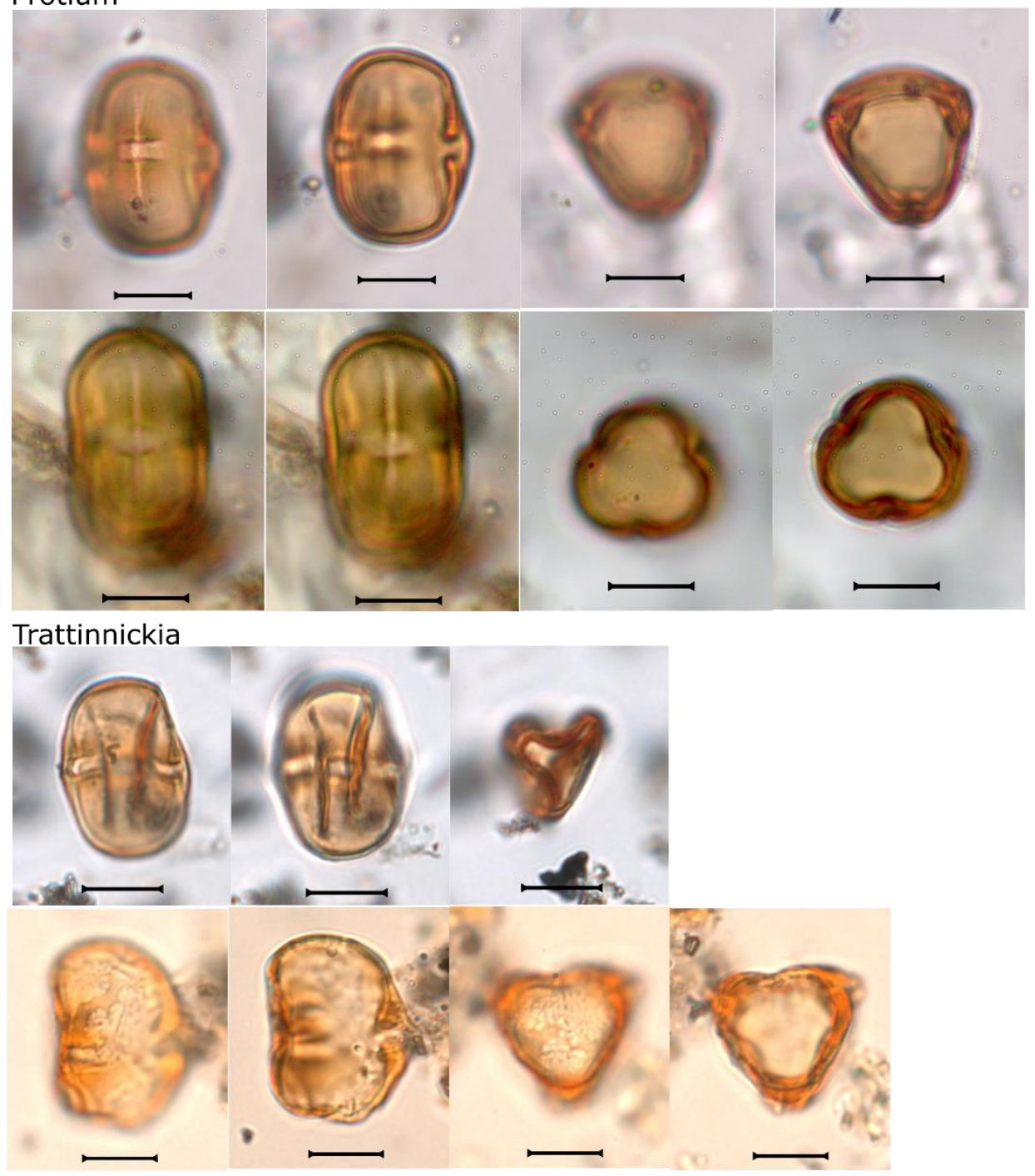
Cannabaceae

Plate X

Celtis

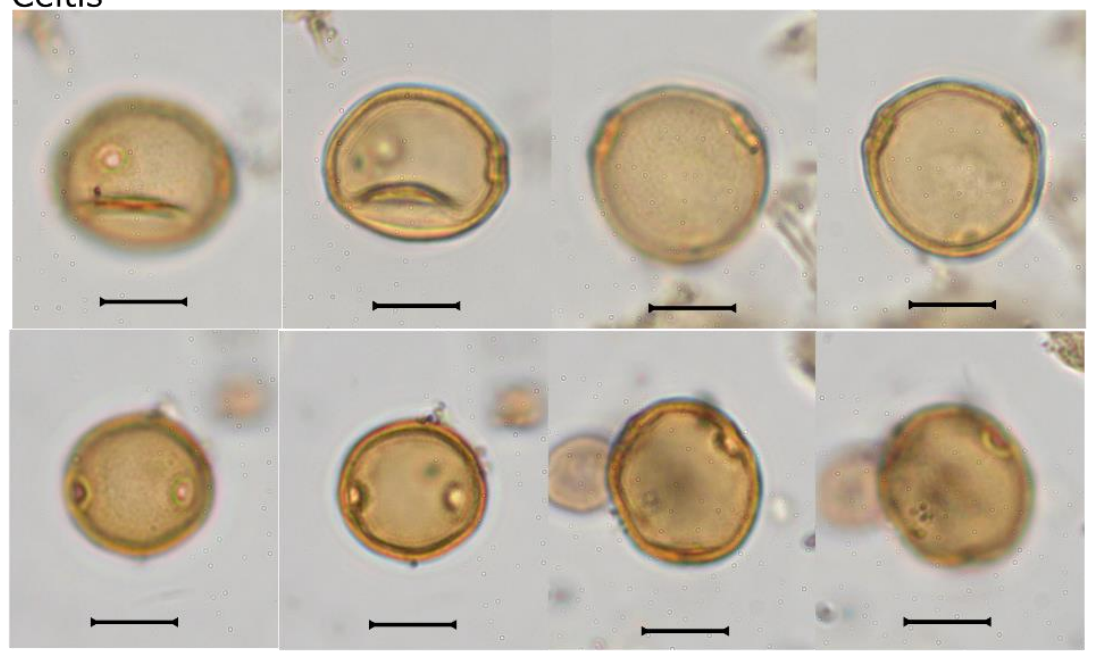

\section{Caprifoliaceae}

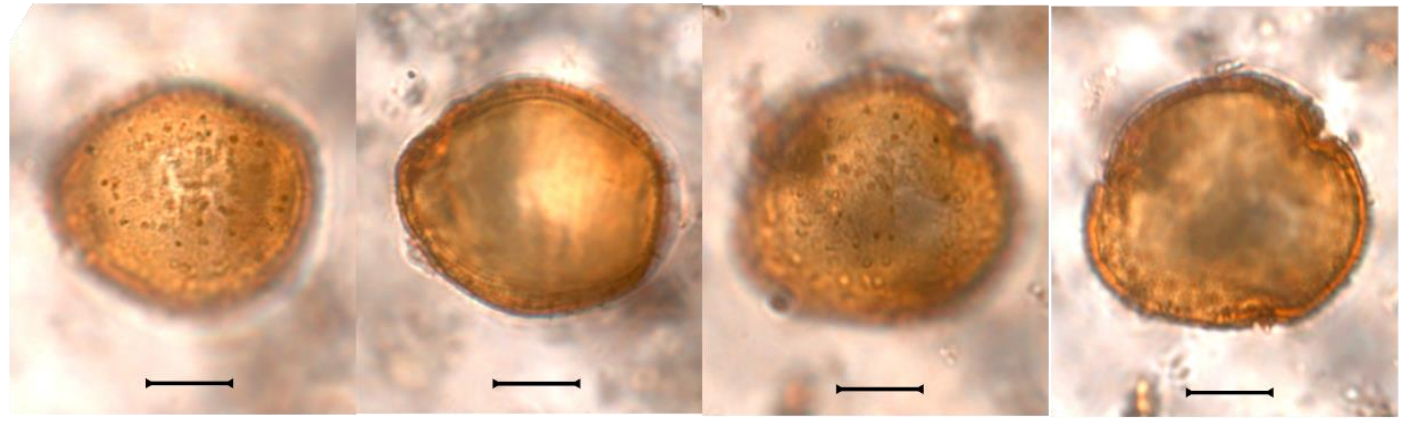

\section{Celastraceae}

Cheiloclinium

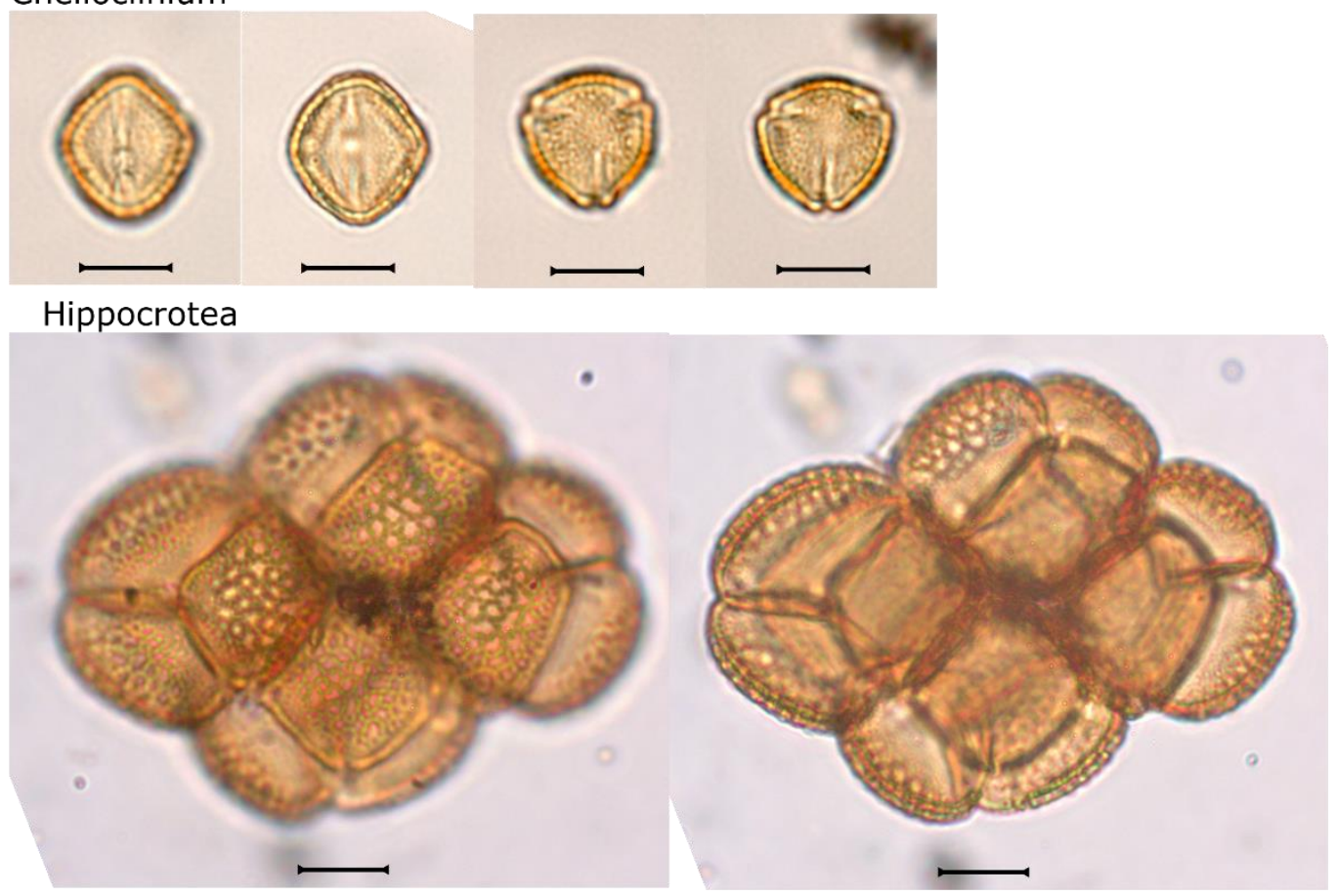


Celastraceae

Plate XI

Maytenus
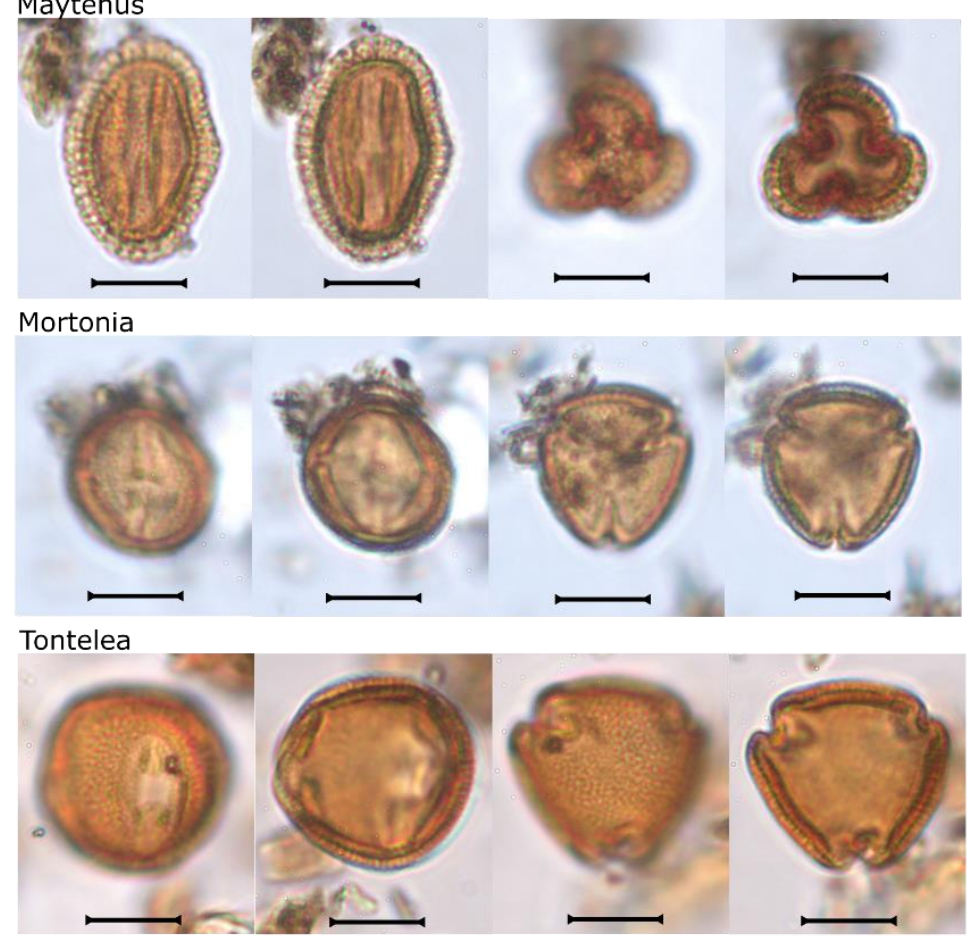

Celastraceae 1

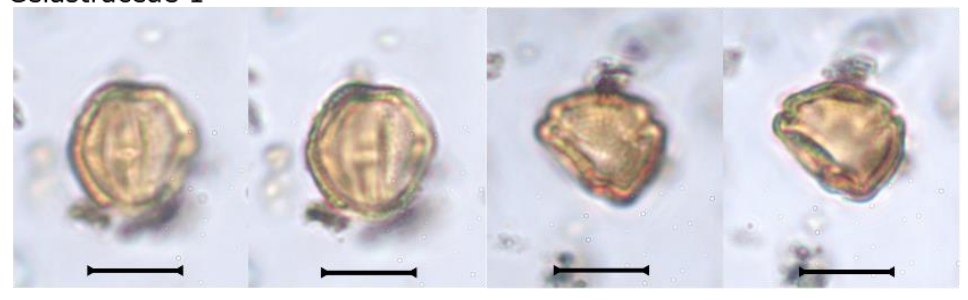

Celastraceae 2

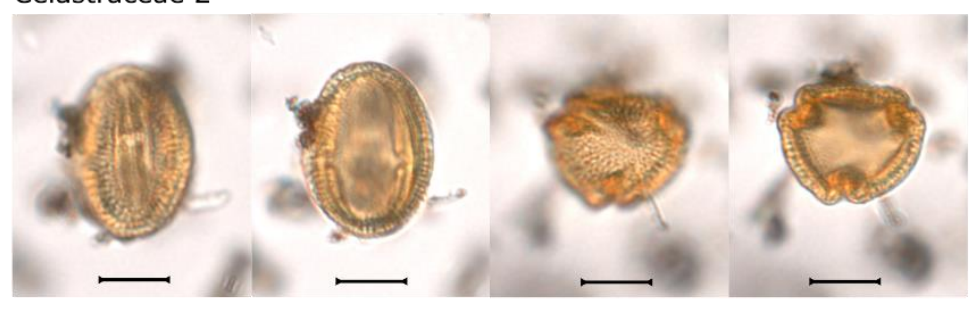

\section{Chloranthaceae}

Hedyosmum
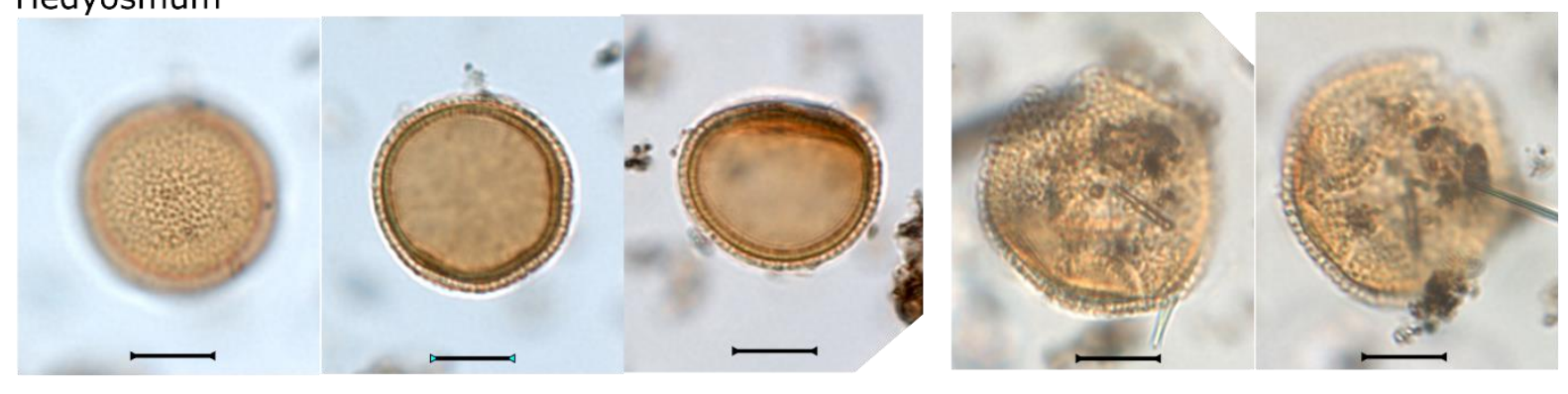


\section{Chrysobalanaceae}

\section{Plate XII}

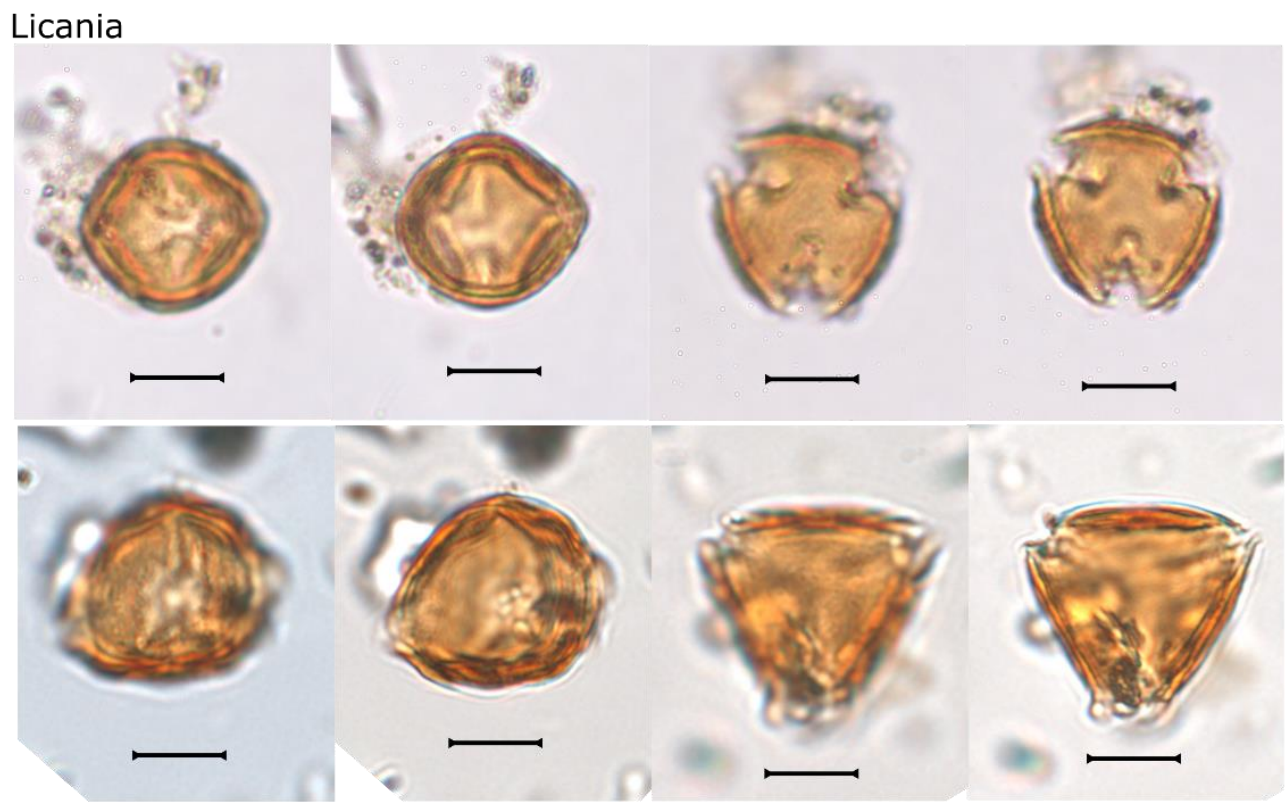

Exellodendron

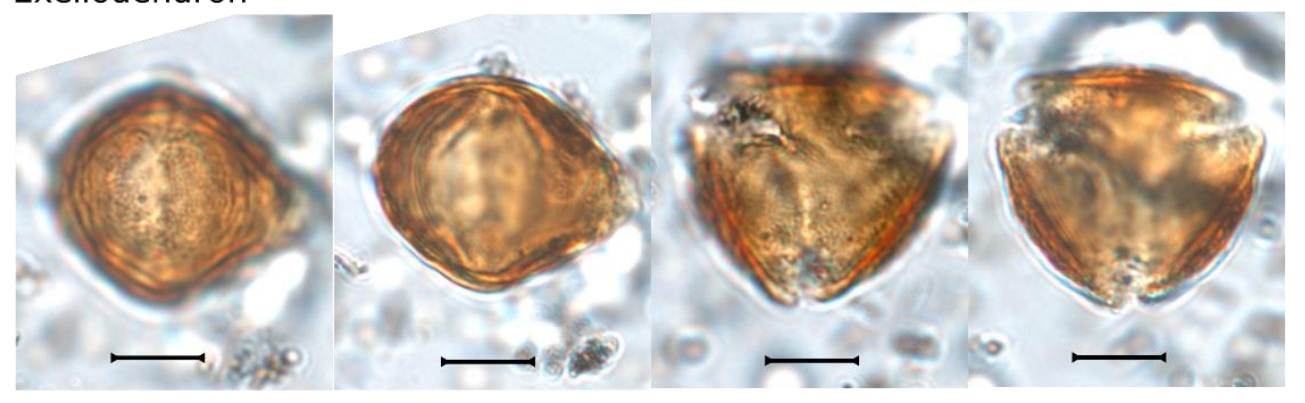

\section{Clusiaceae}

\section{Symphonia}

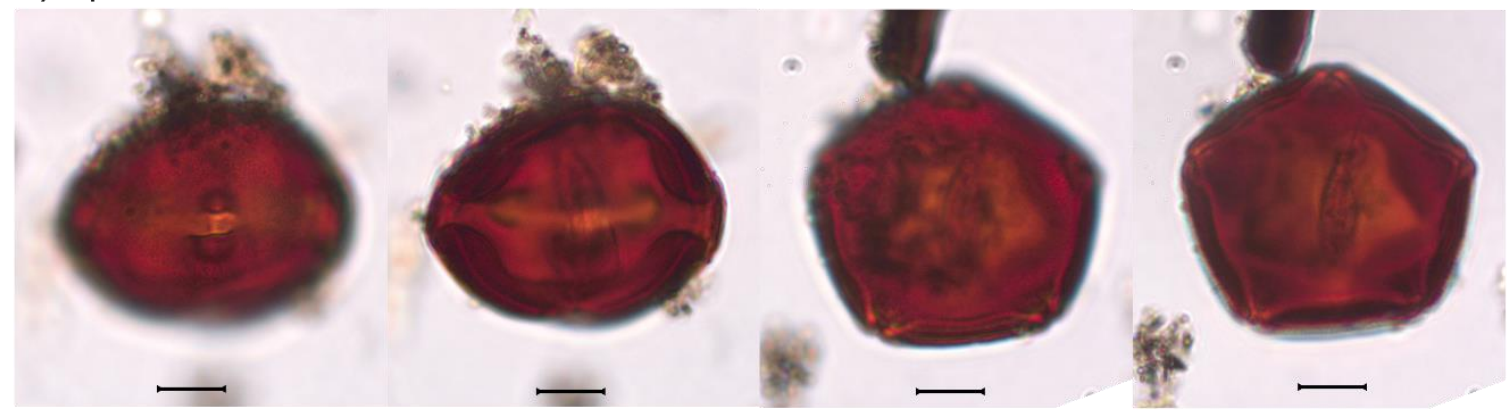


Convolvulaceae

Plate XIII

Dicranostyles

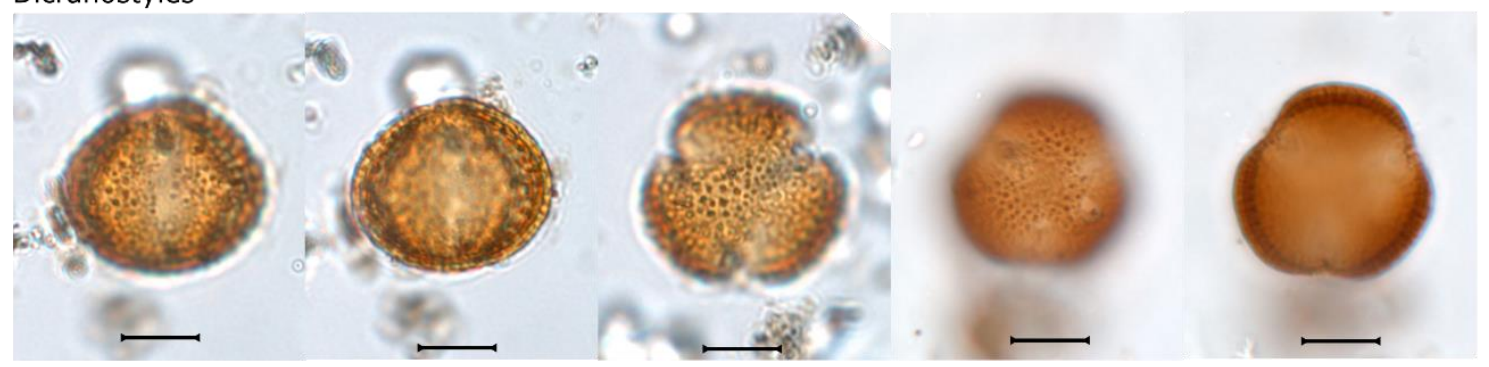

Evolvulus

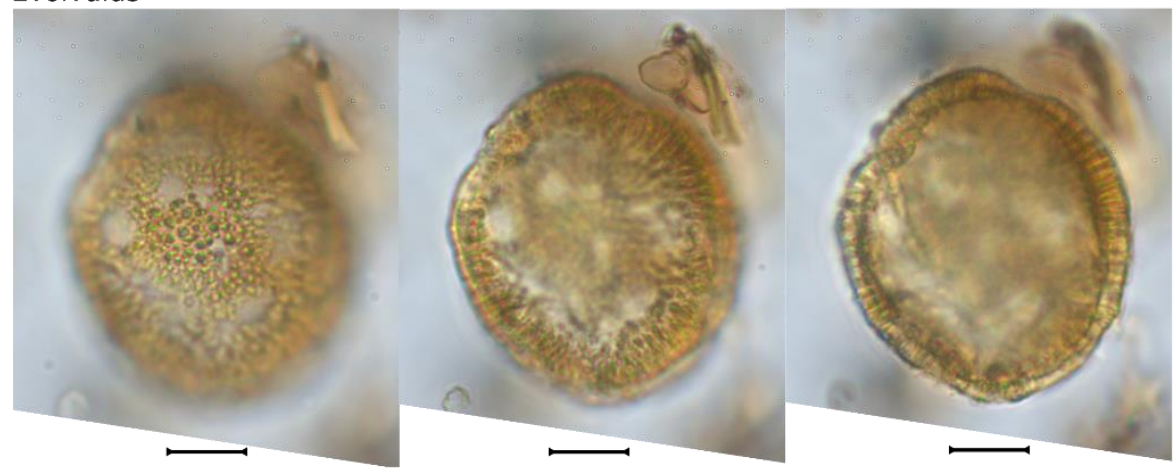

Ipomoea
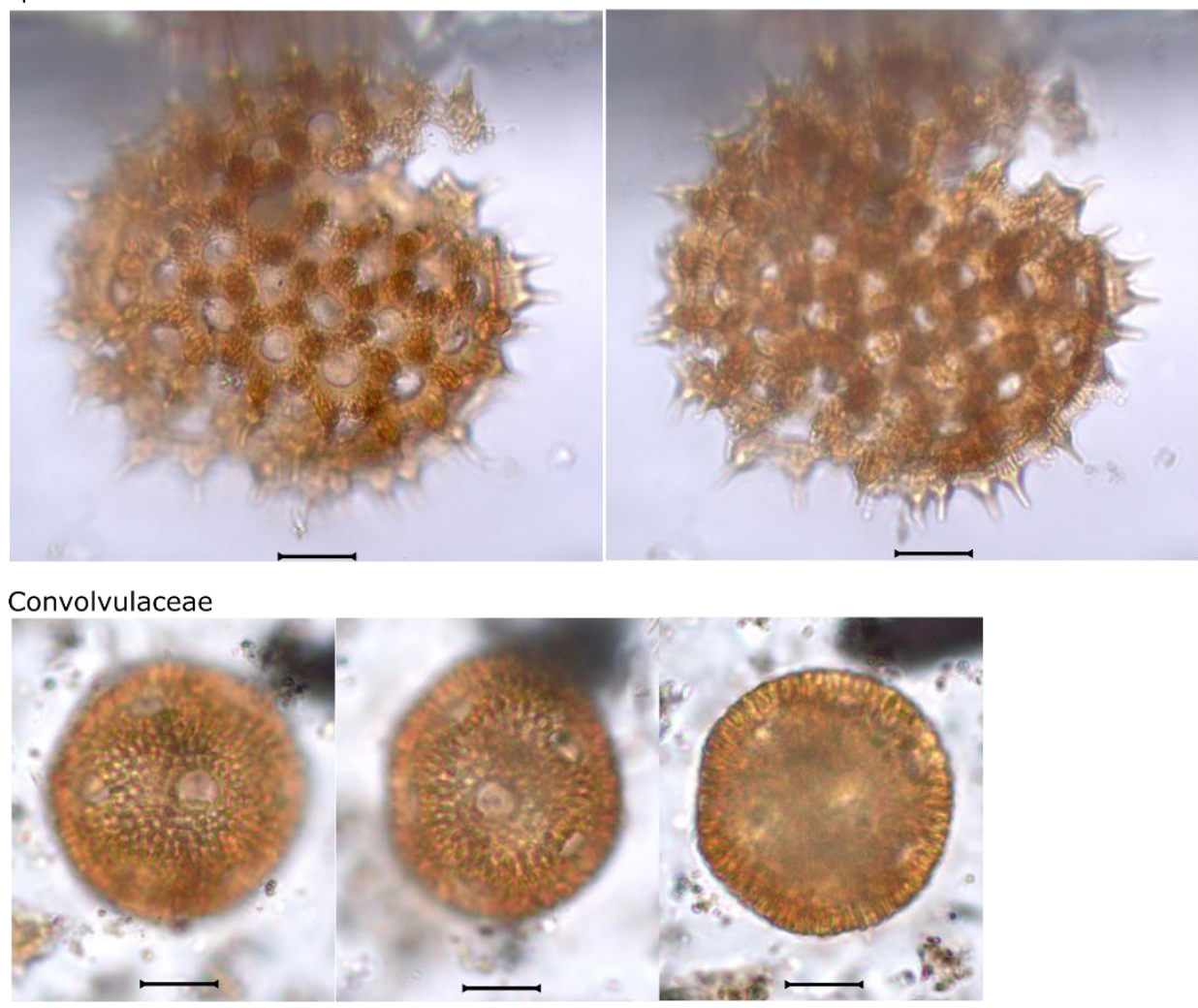


\section{Curcubitaceae}

\section{Plate XIV}

\section{Cayaponia}

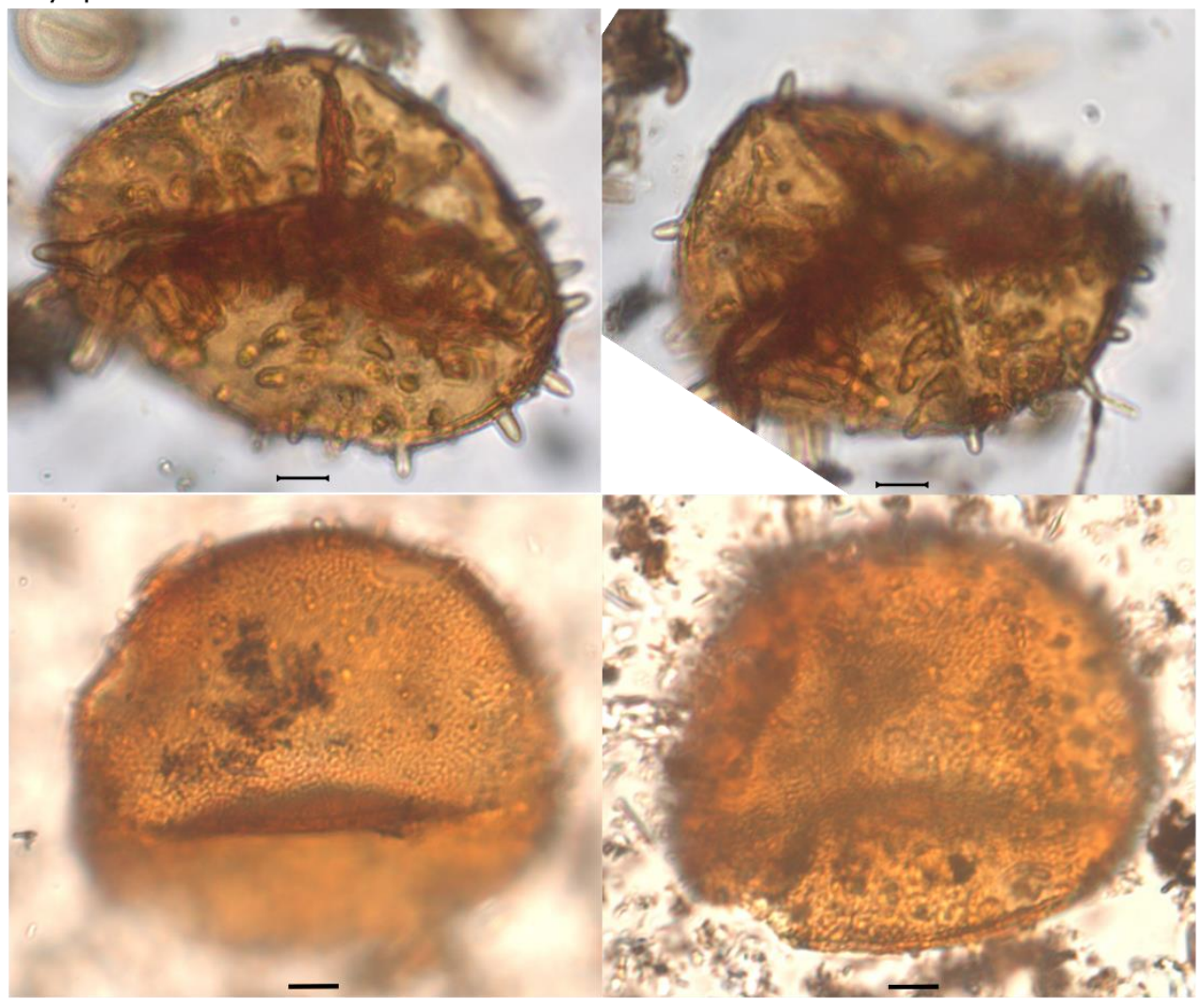

\section{Cunoniaceae}

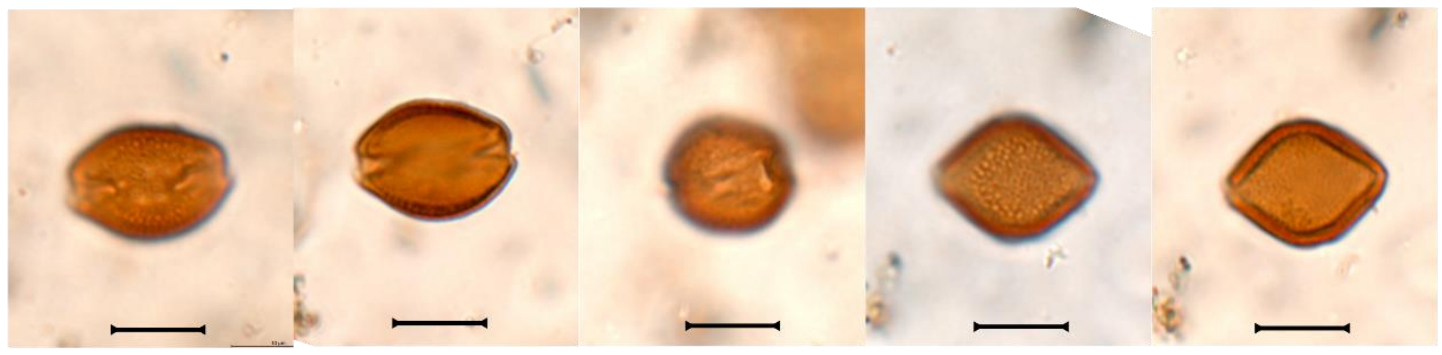

\section{Cyperaceae}
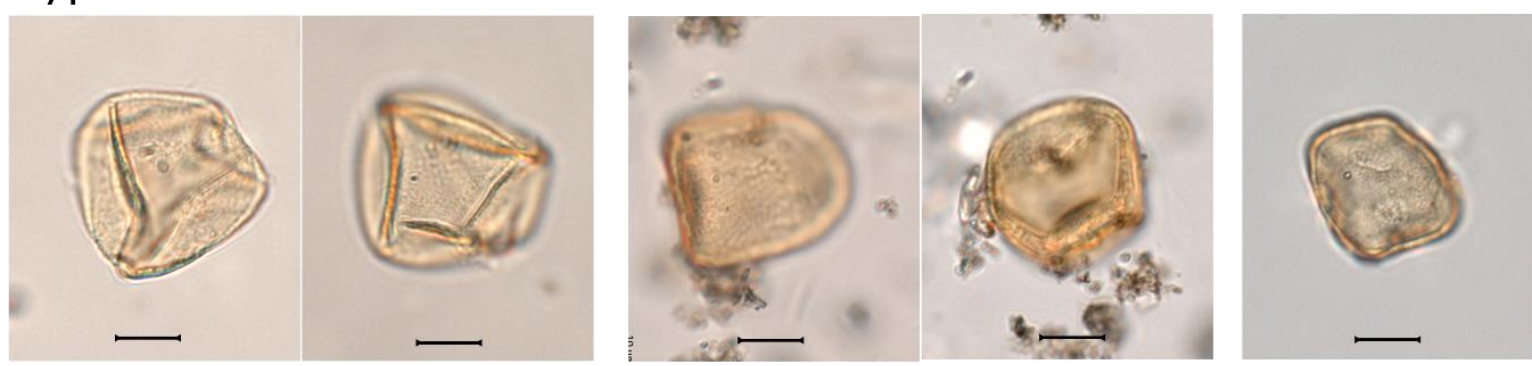


\section{Dilleniaceae}

Plate XV

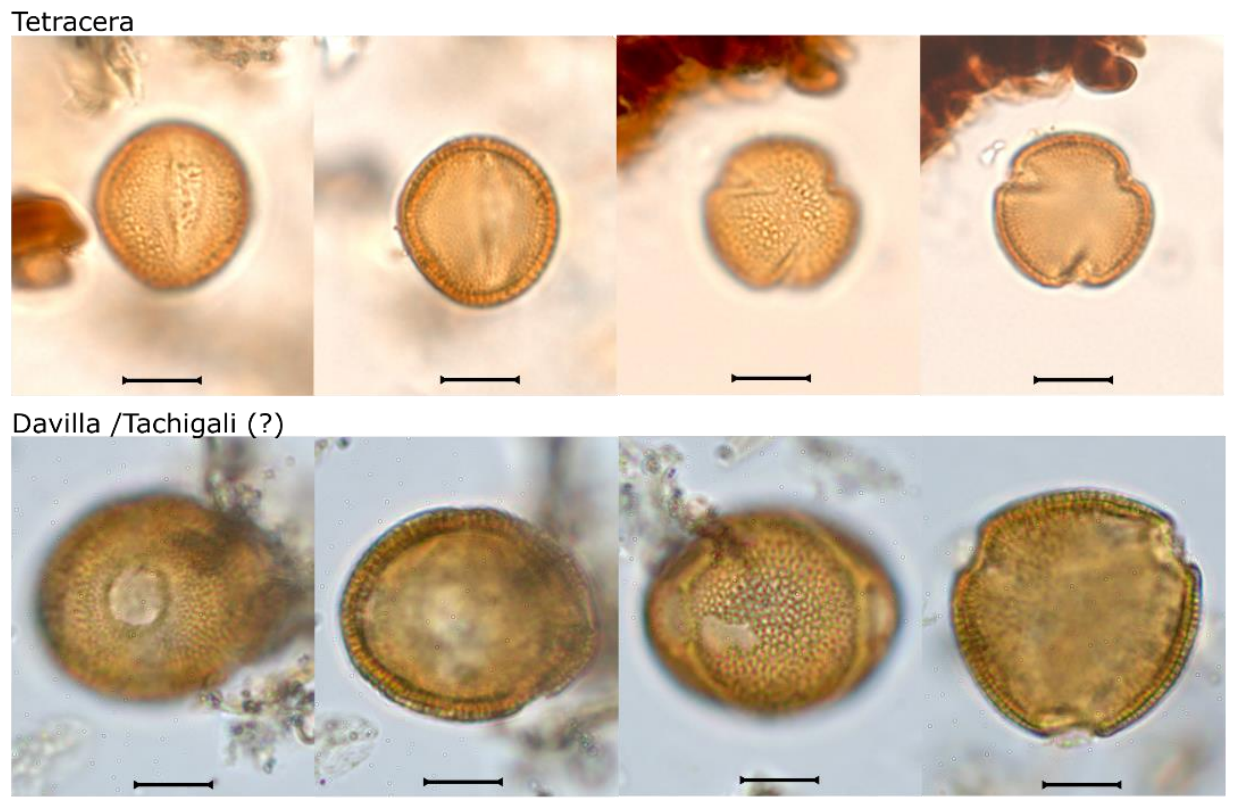

\section{Eleocarpaceae}

Sloanea

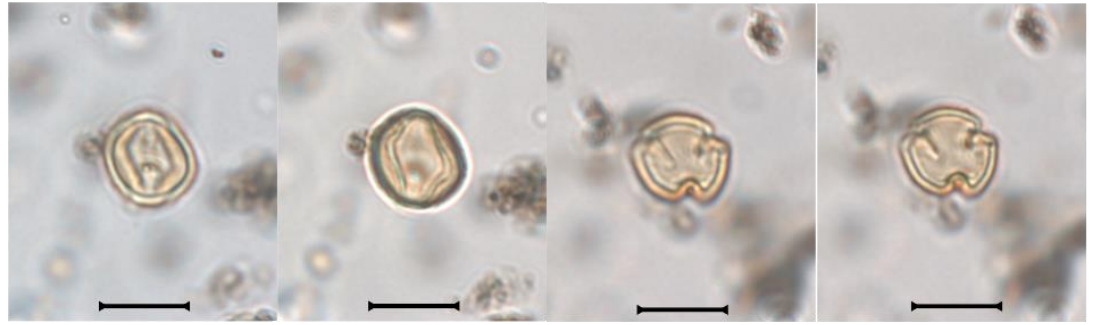

\section{Ericaceae}

Gaylussacia

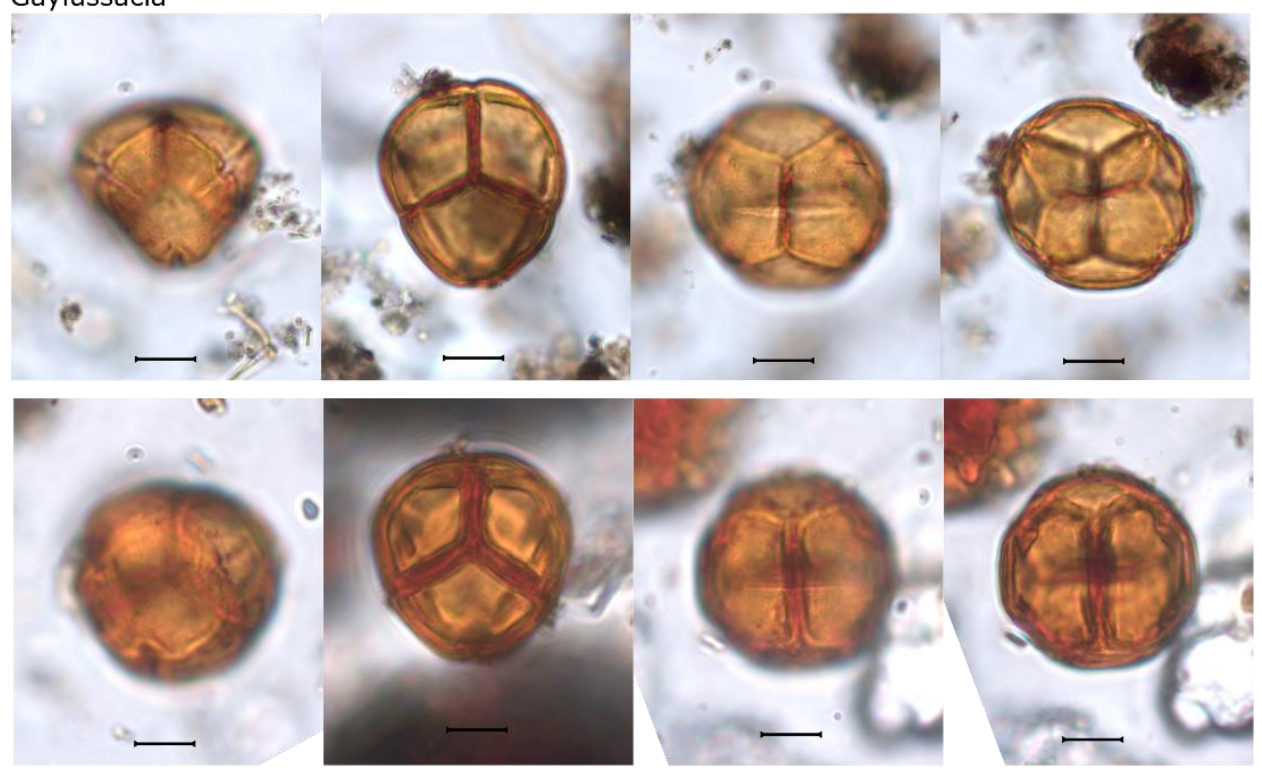


Euphorbiaceae

Plate XVI

Acalypha
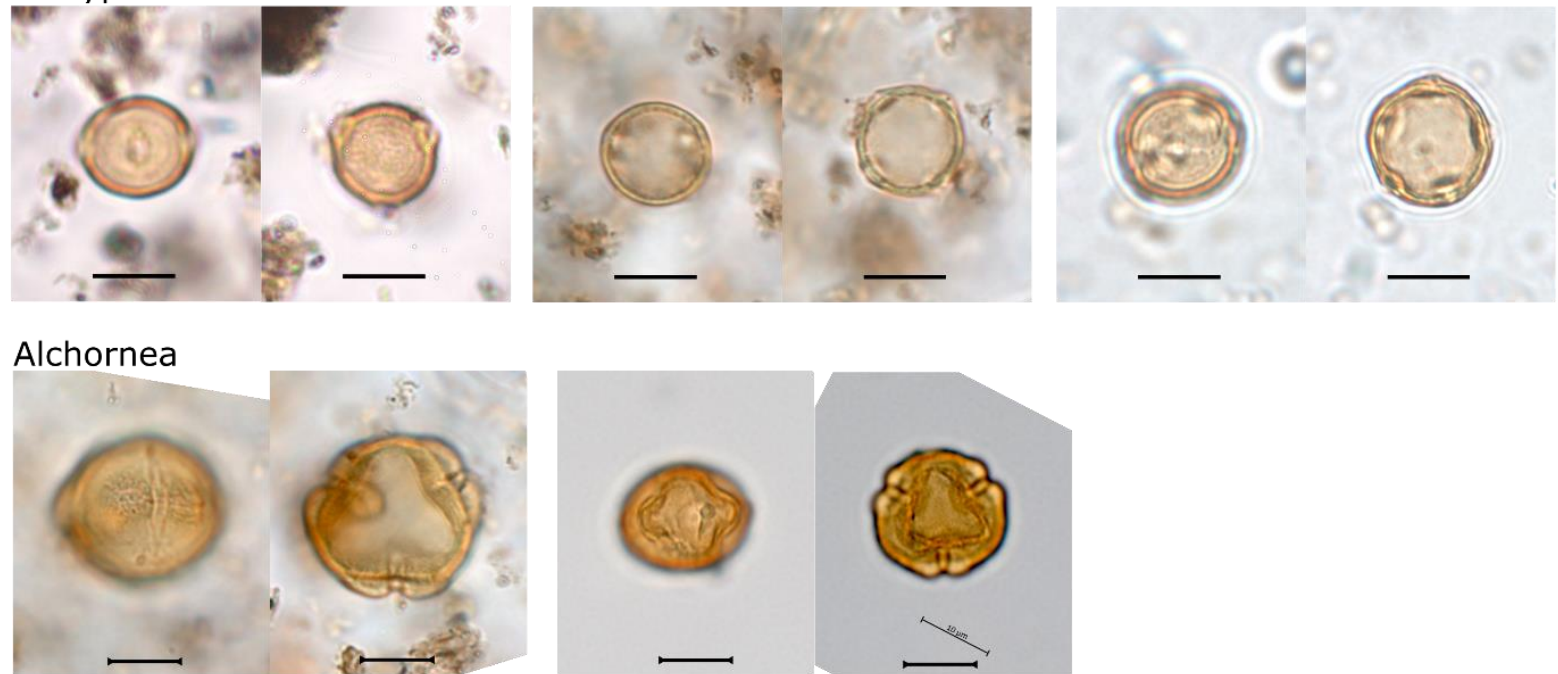

Bernardia

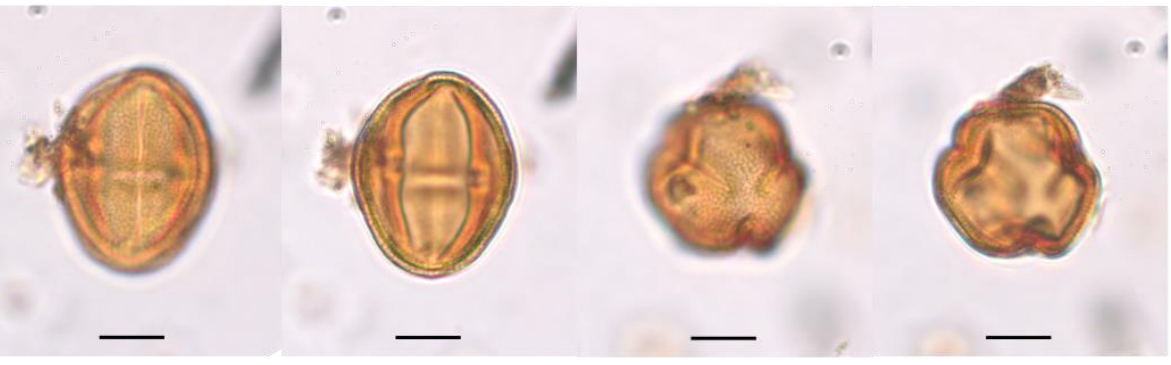

Croton/Micrandra

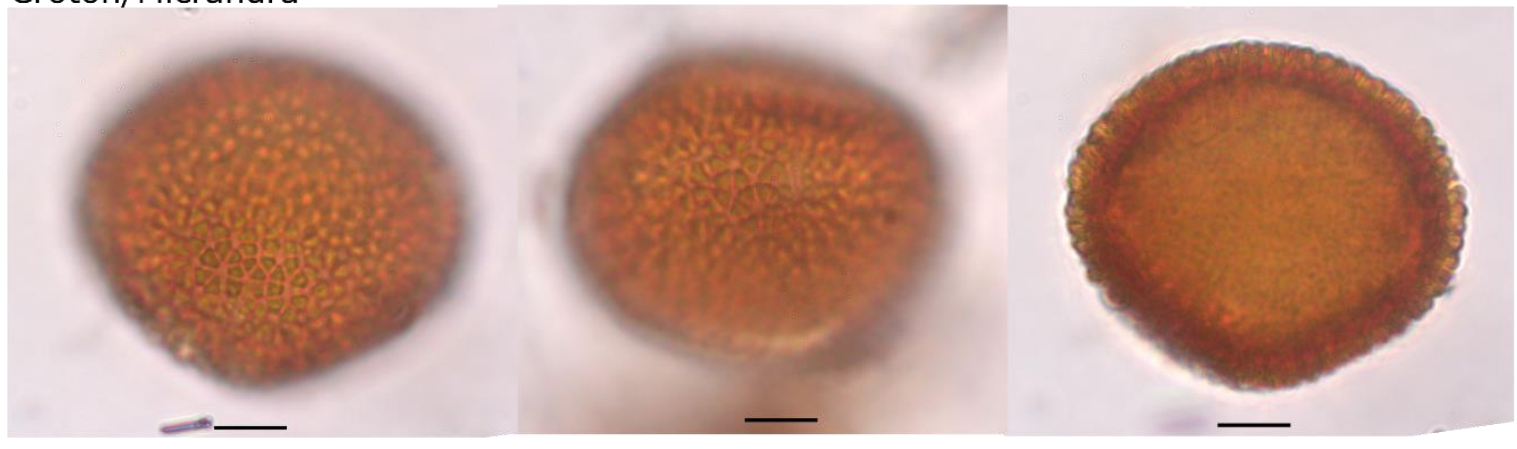

Dalechampia

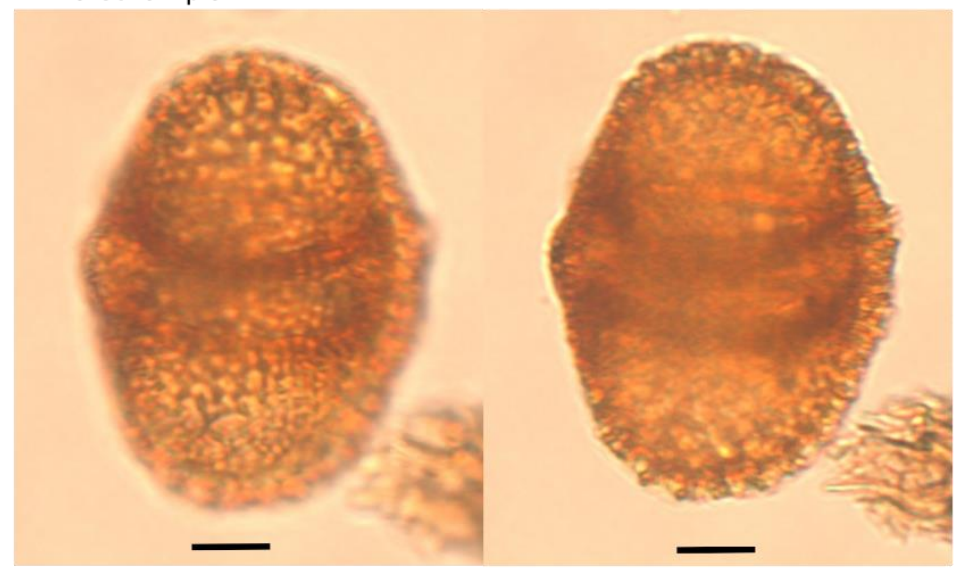


Euphorbiaceae

Plate XVII
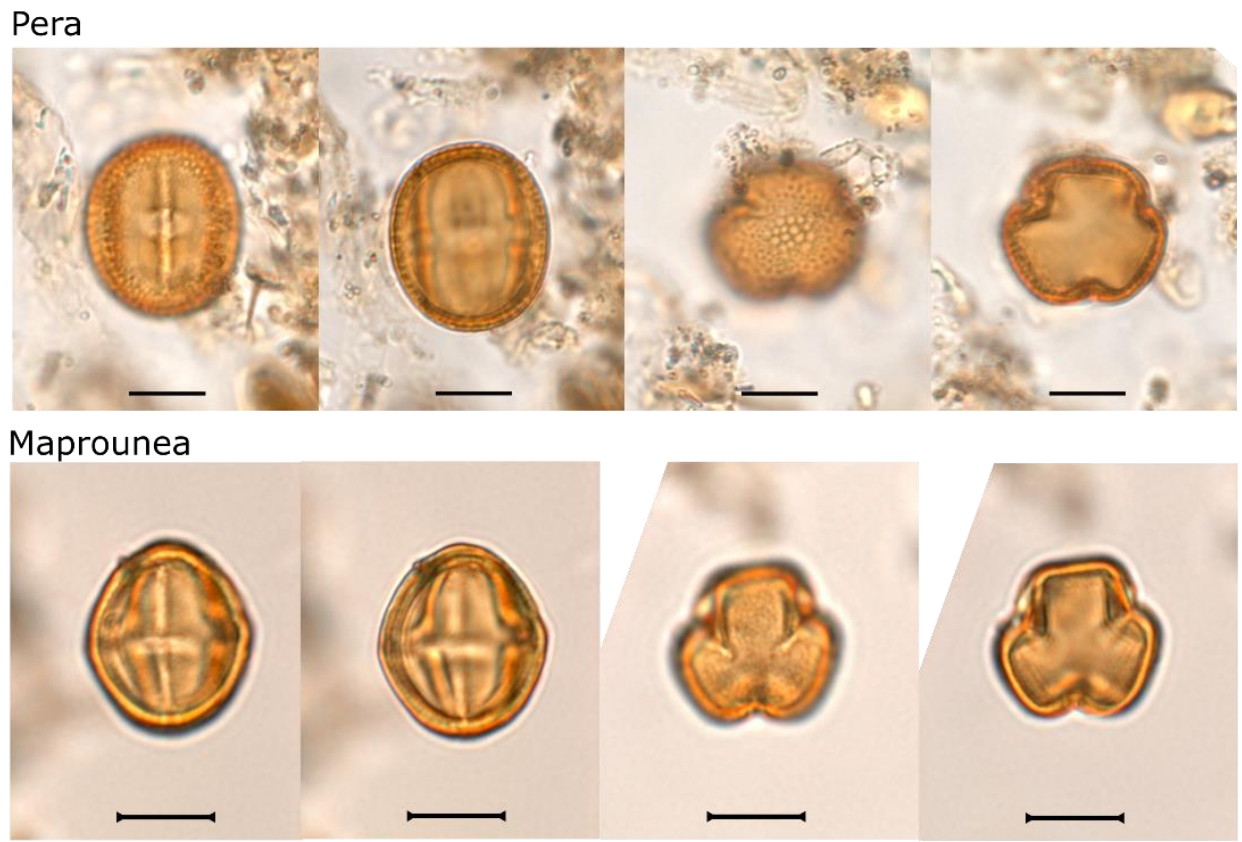

\section{Sapium/Chamaesyce}

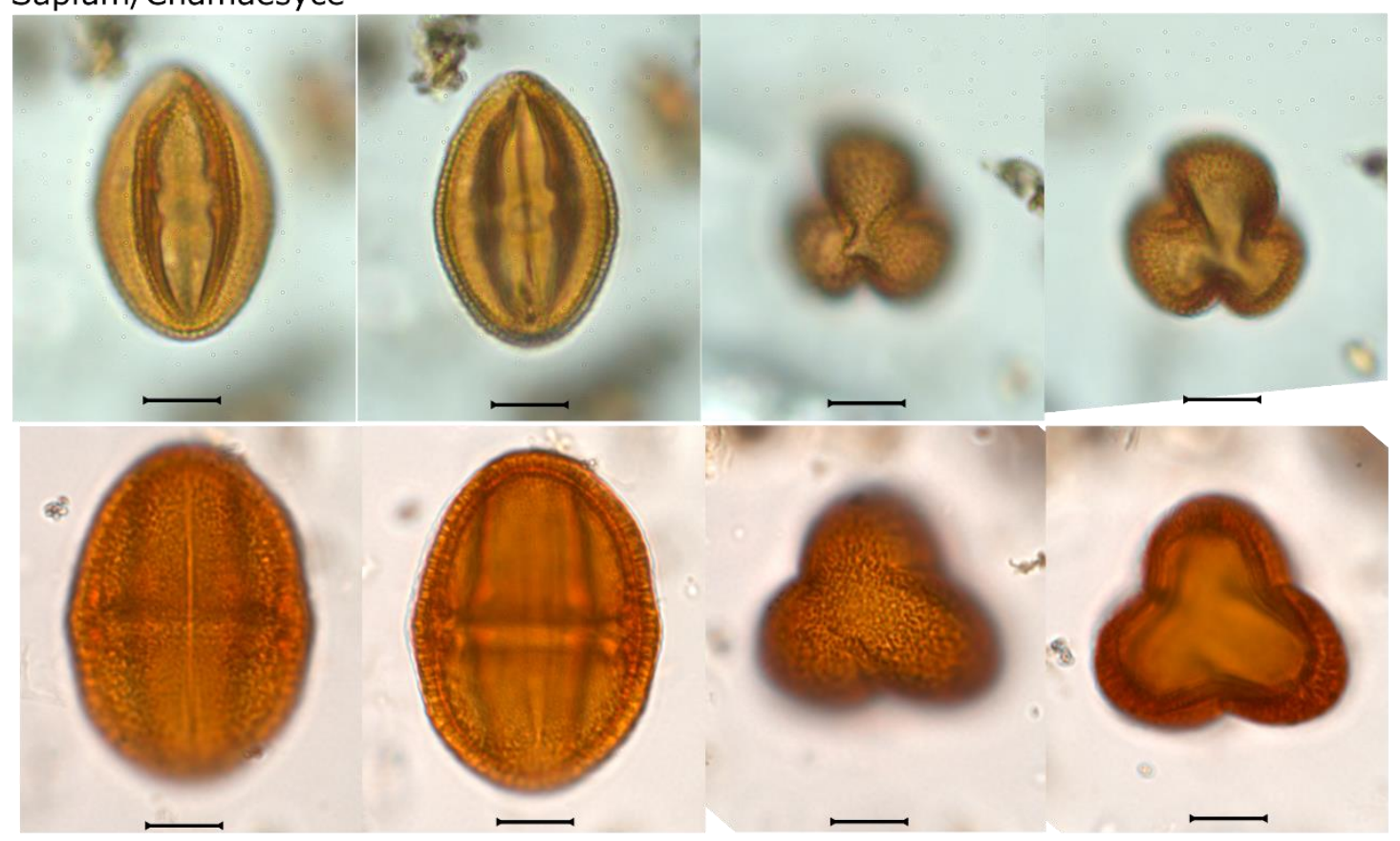


Fabaceae

Plate XVIII

Caesalpinioideae

Bauhinia cf. reflexa

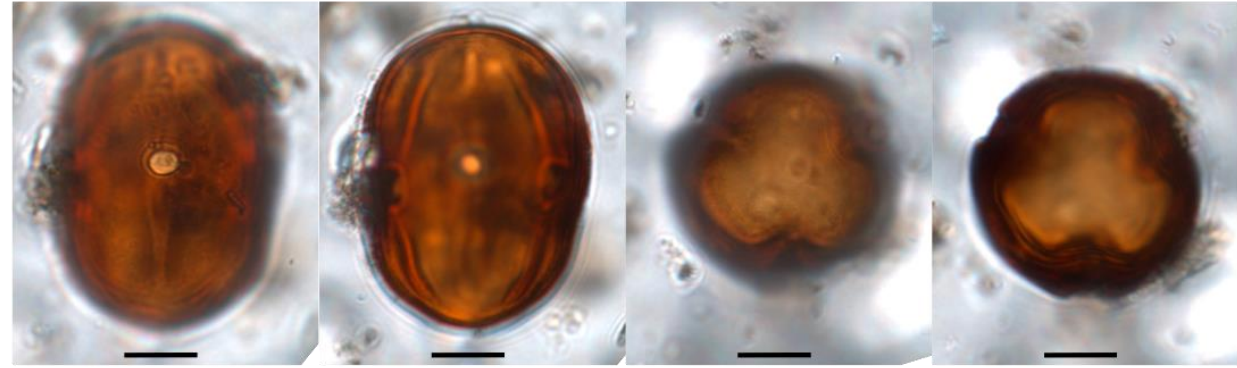

Cassia

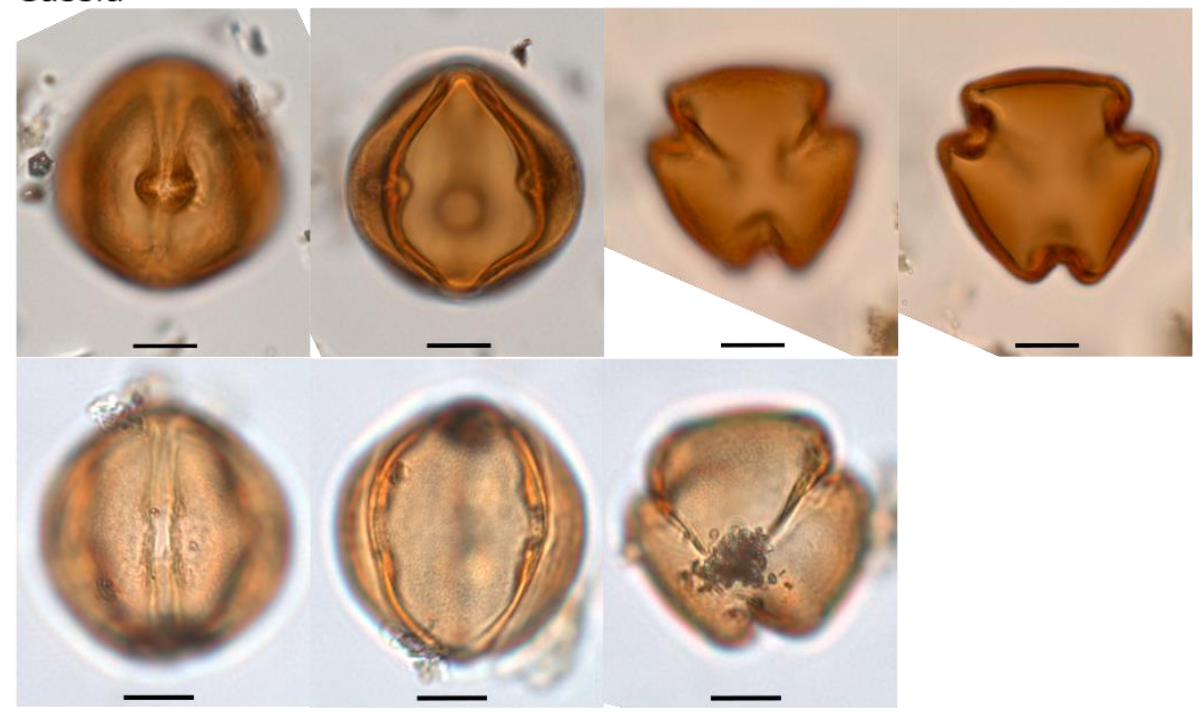

Cenostigma

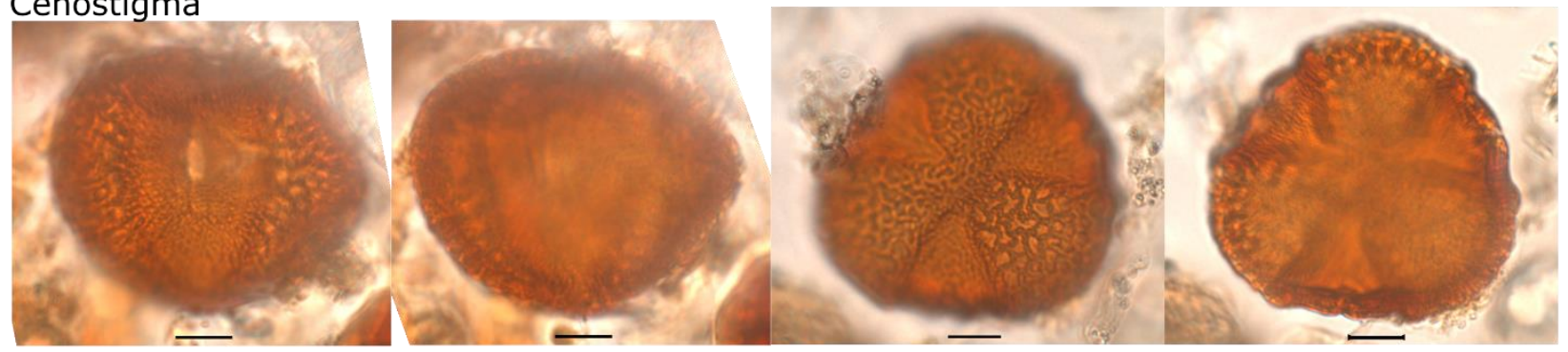

\section{Copaifera}

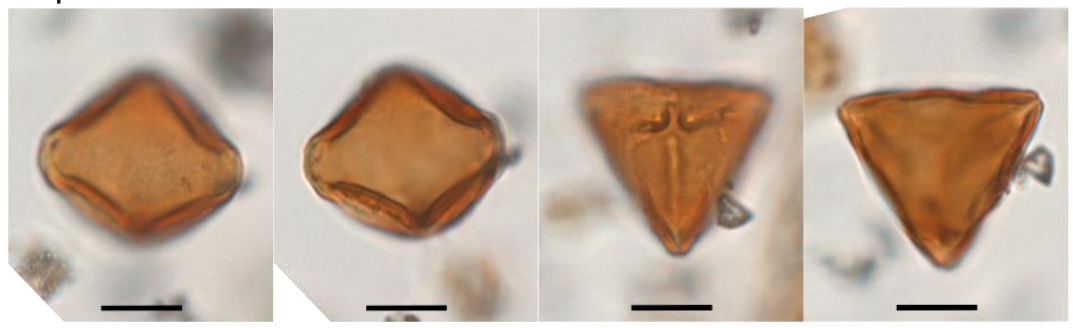


Fabaceae

Plate XIX

Caesalpinioideae

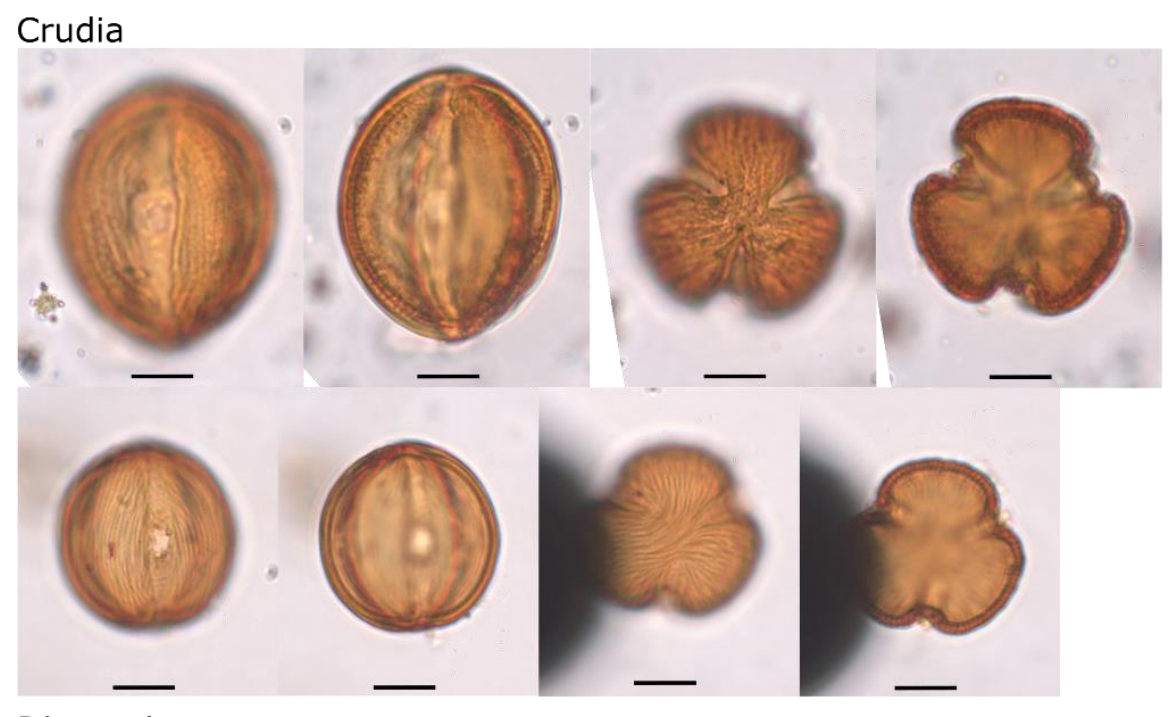

Dicorynia

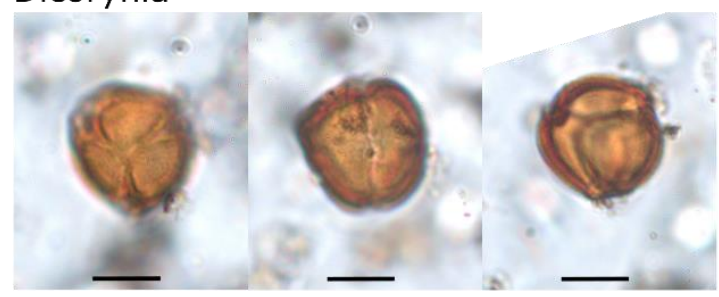

cf. Eperua

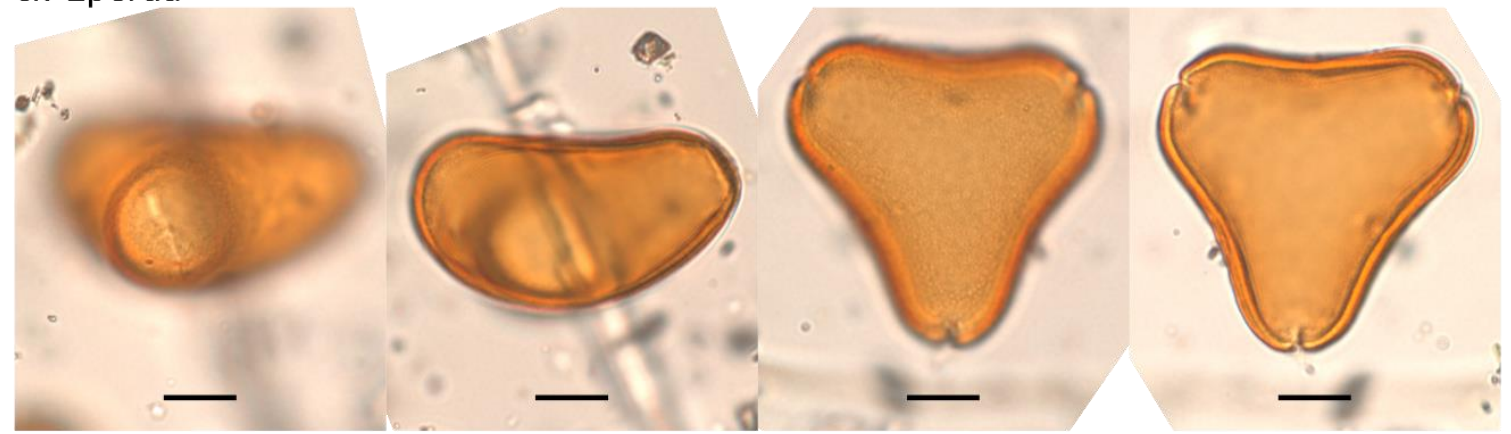

Macrolobium

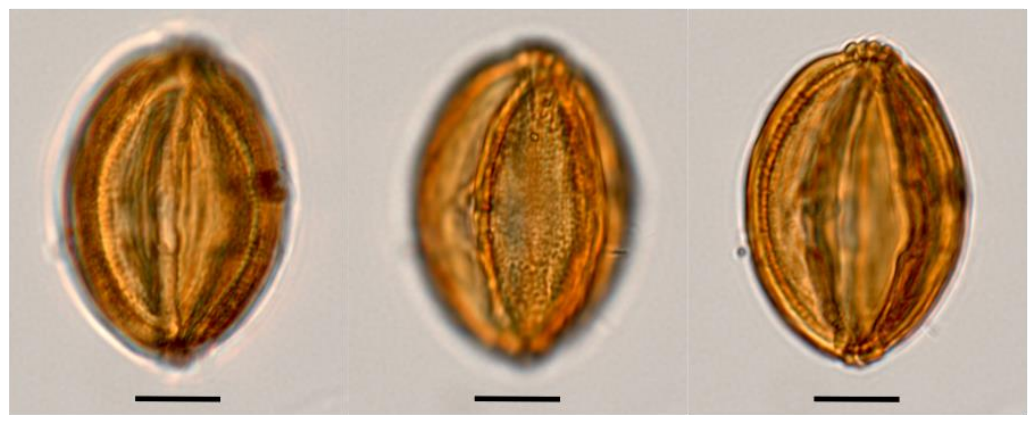


Fabaceae

Plate XX

Caesalpinioideae

Parkisonia

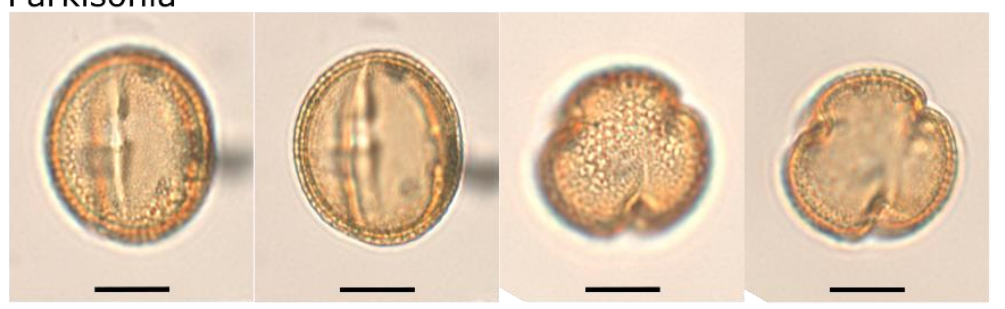

Phanera

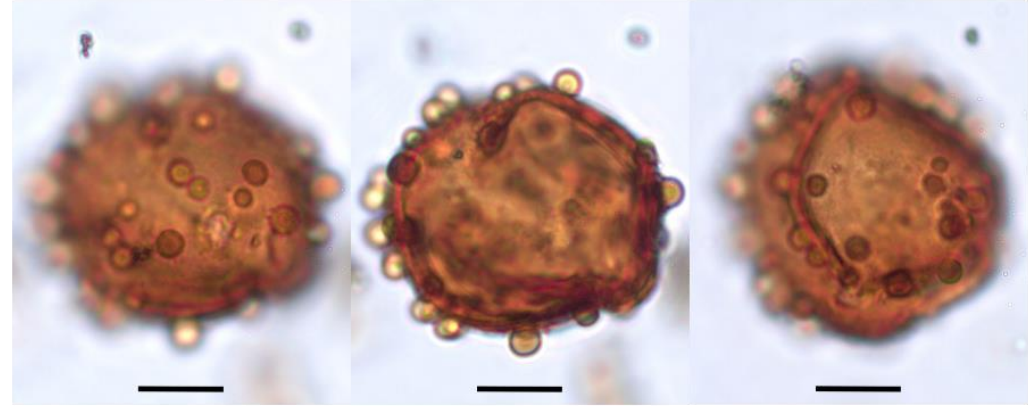

Tachigali

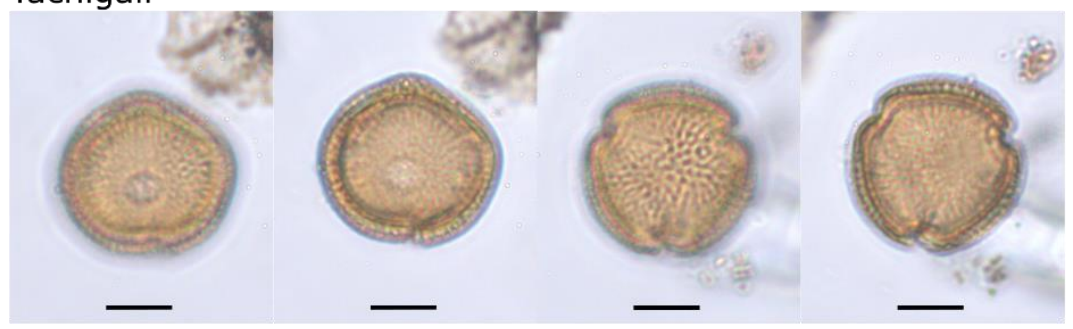

Mimosoideae

Acacia?

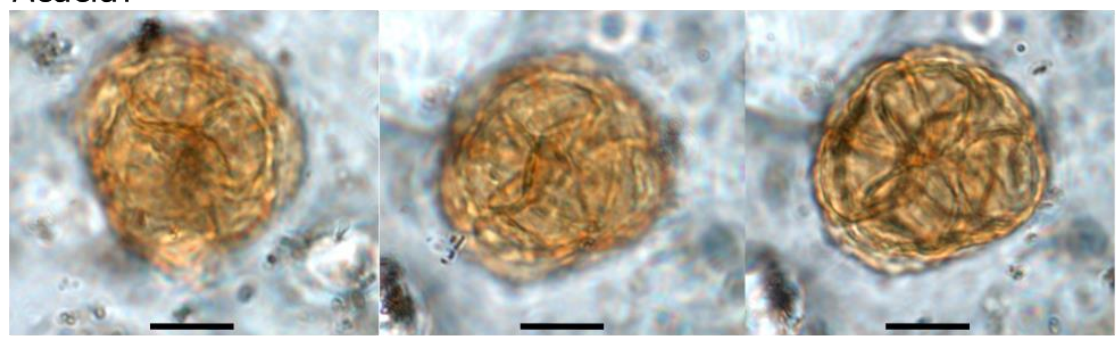

Anadenanthera

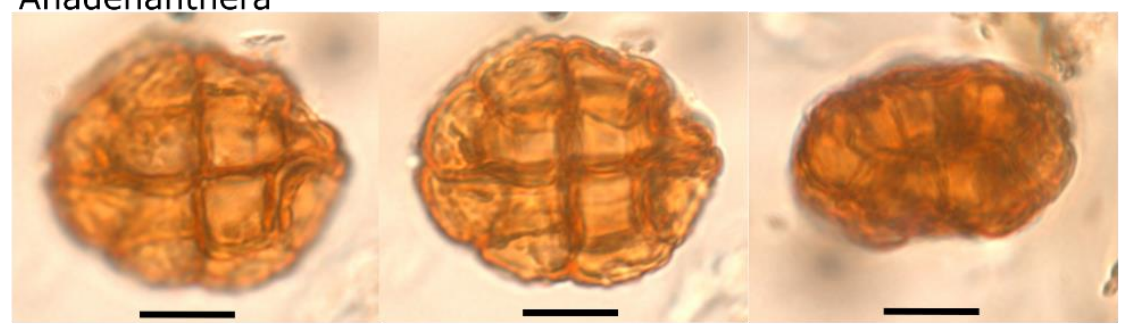


Fabaceae

Plate XXI

Mimosoideae

Calliandra

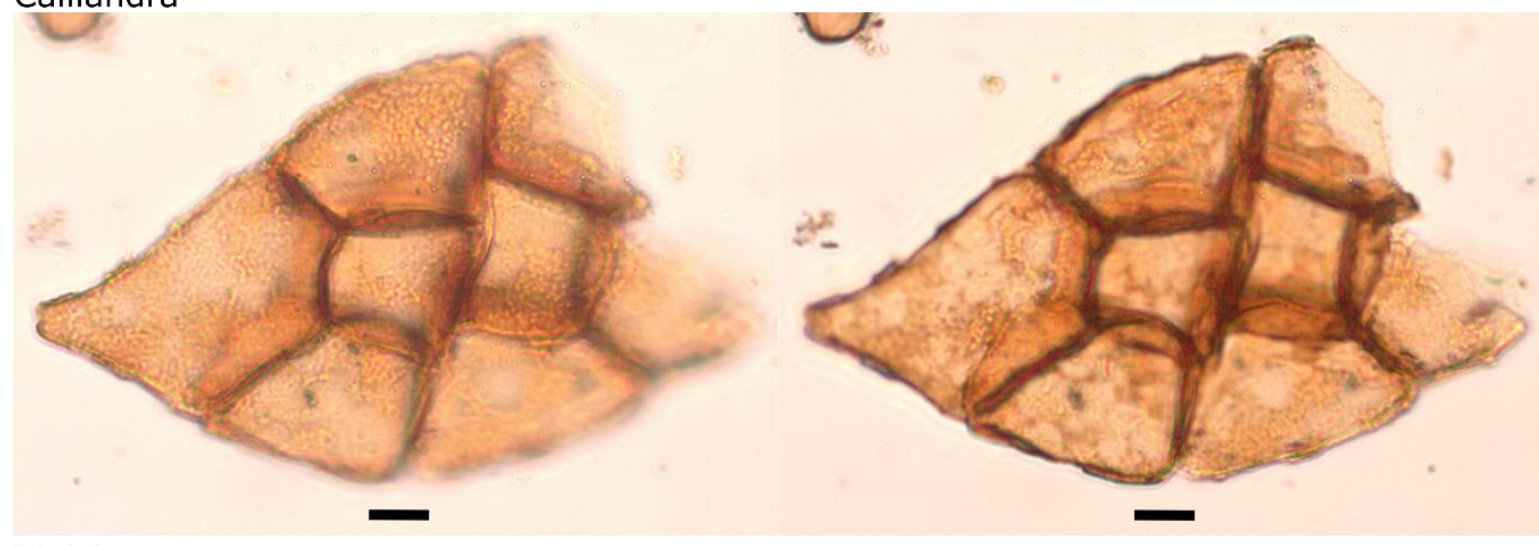

Dinizia

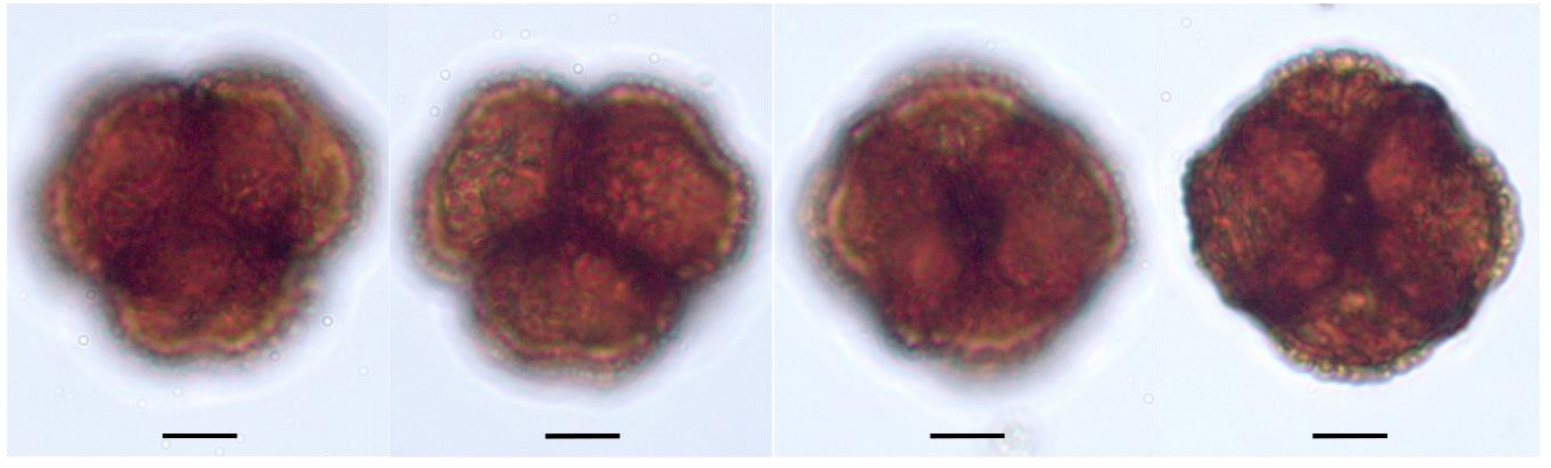

Havardia

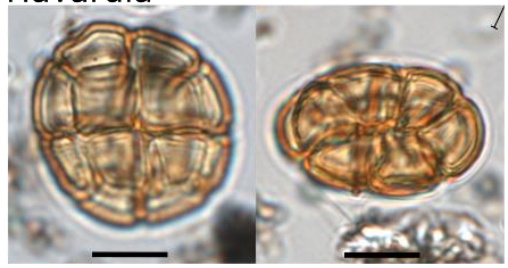

Mimosa

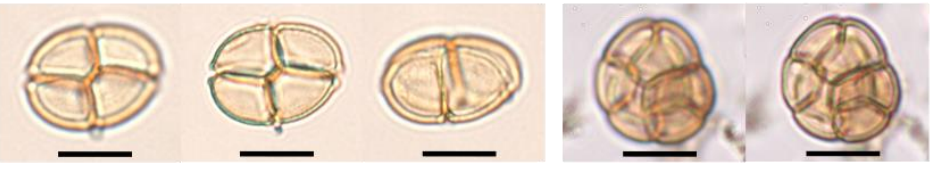

Parkia

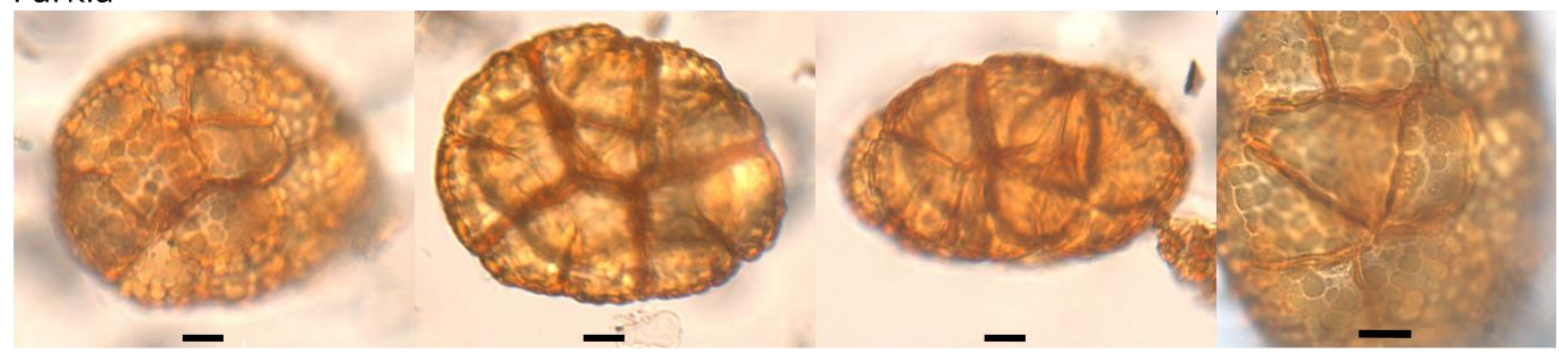

Piptadenia
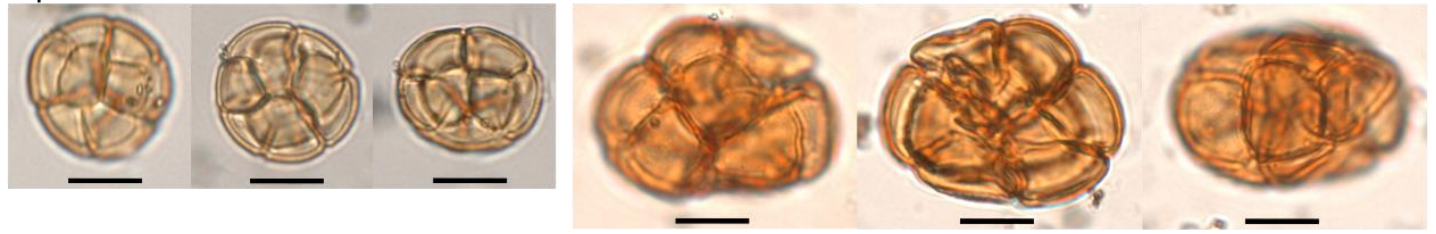
Fabaceae

Plate XXII

Mimosoideae

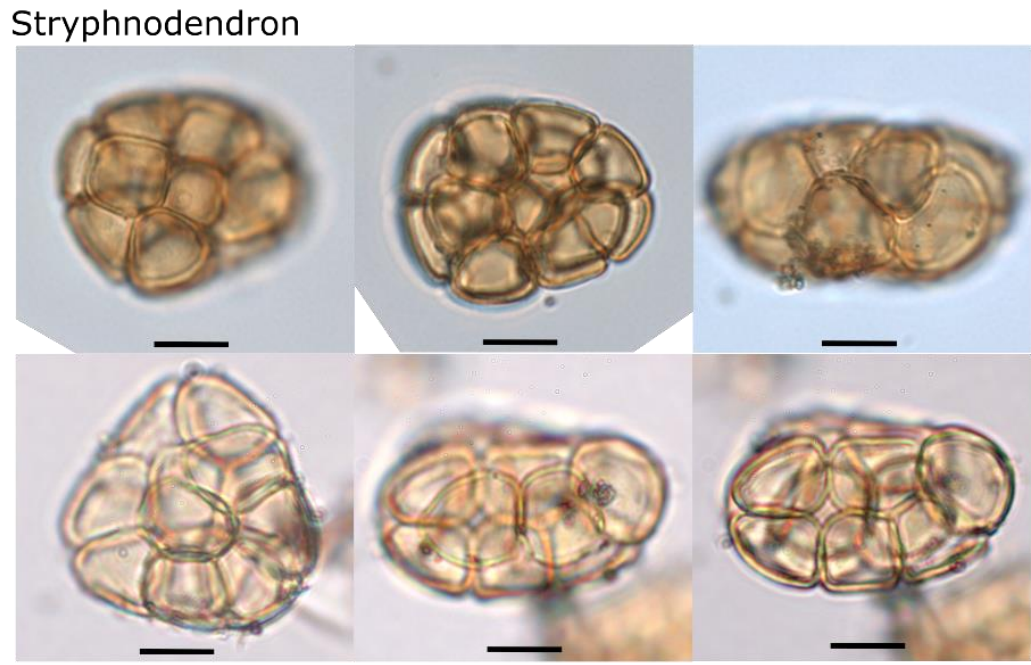

Schrankia

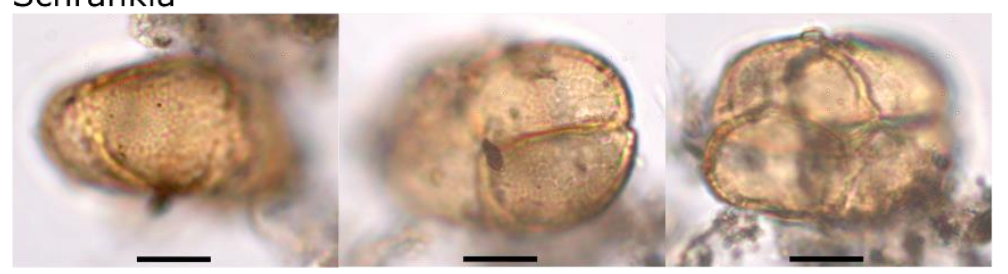

Papilionoideae

Bowdichia

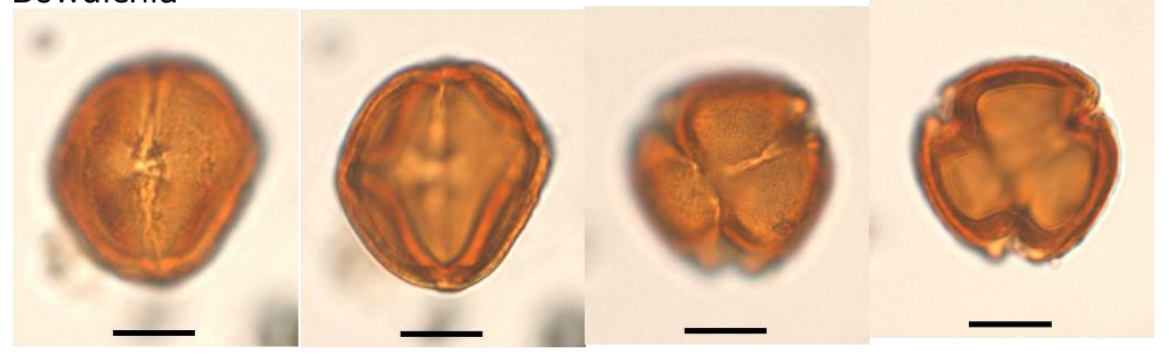

Camptosema

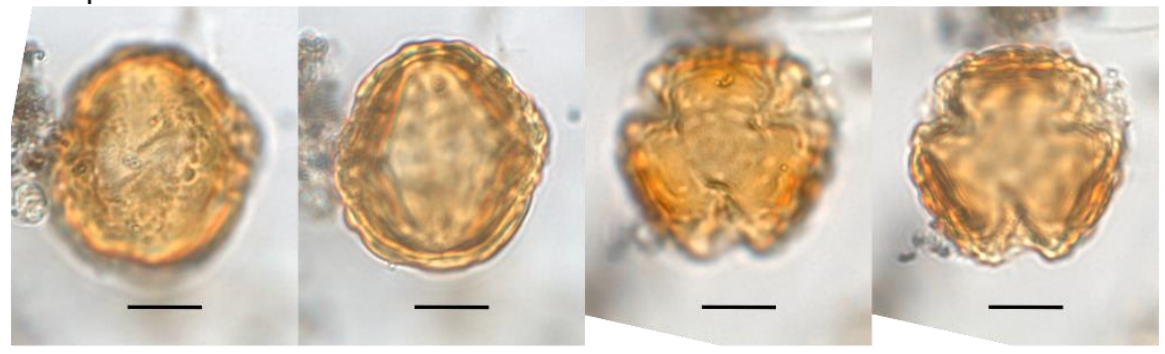


Fabaceae

Plate XXIII

Papilionoideae

Canavalia
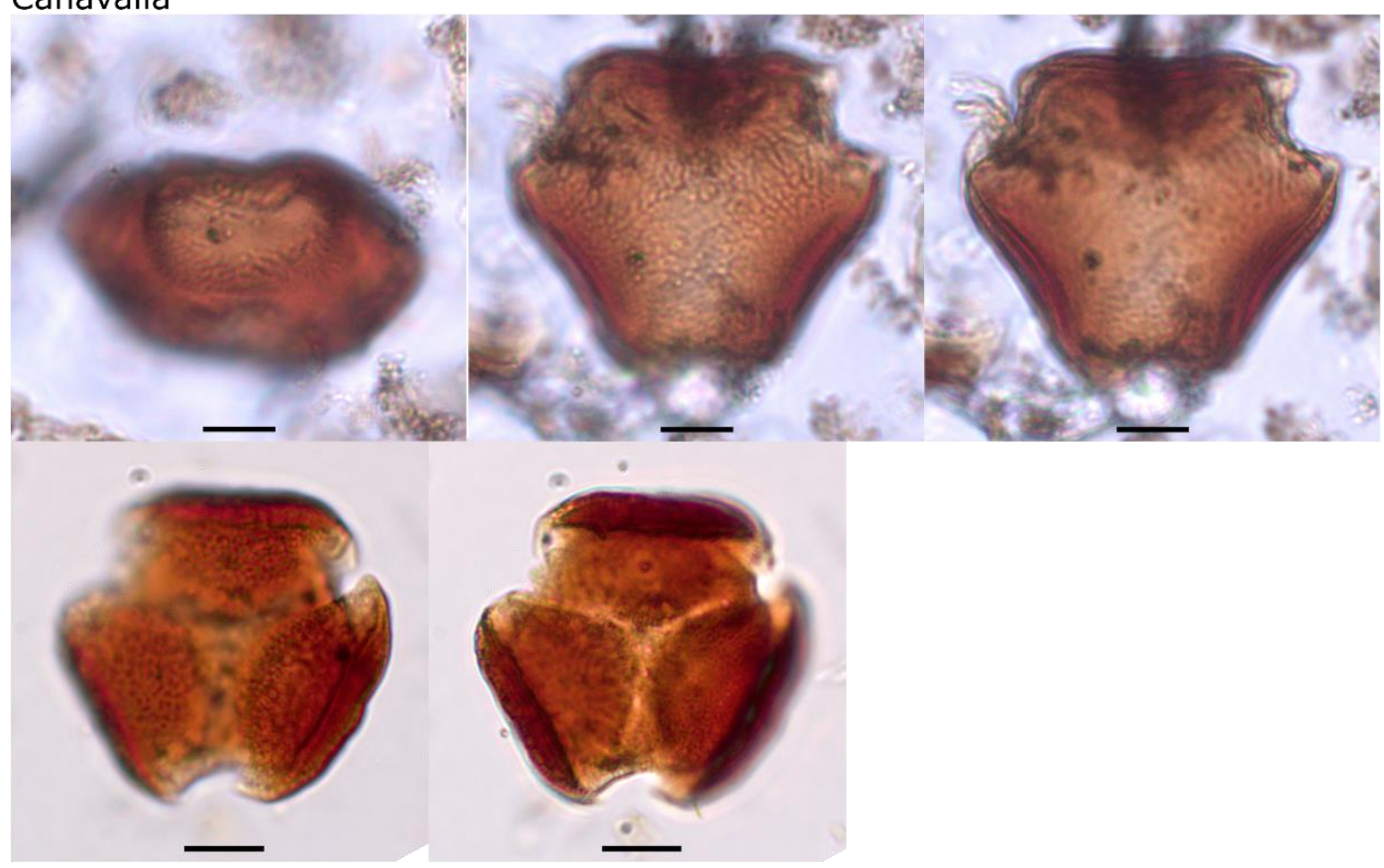

Dalbergia

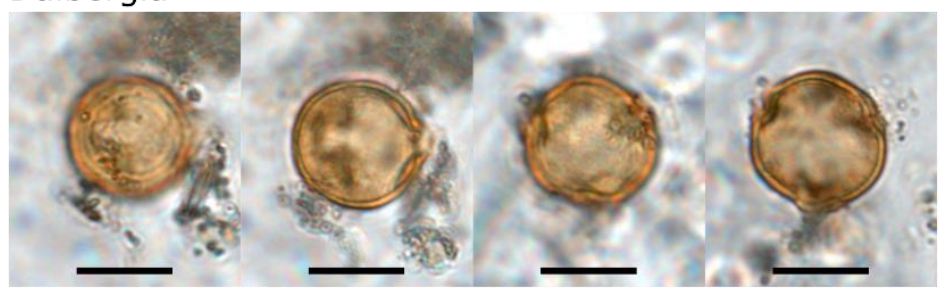

Dipteryx aff. panamensis

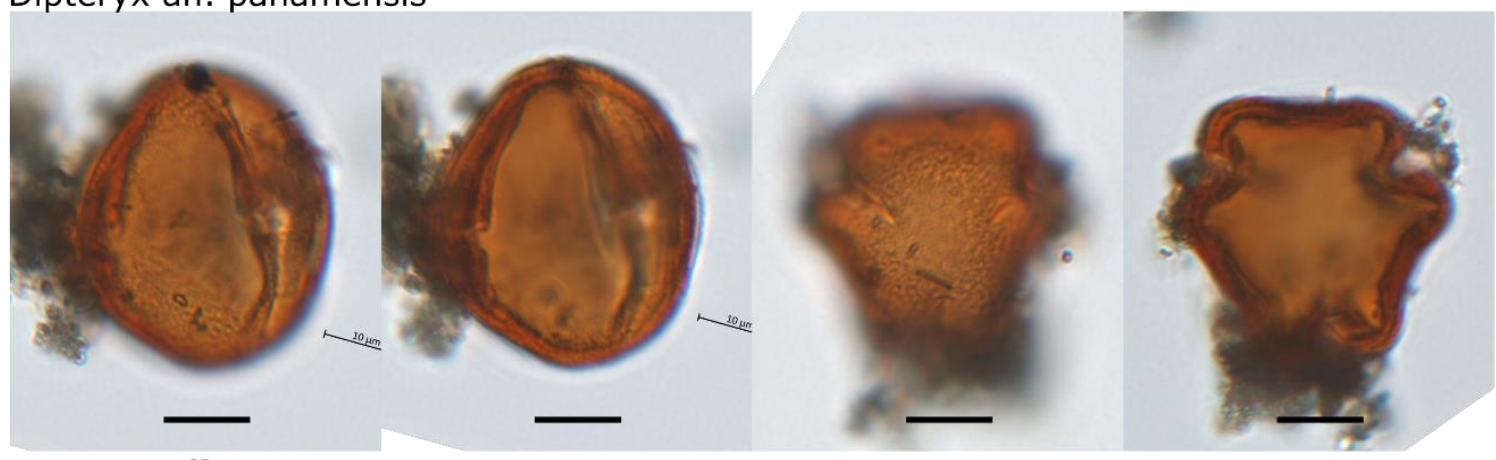

Dipteryx aff. punctata

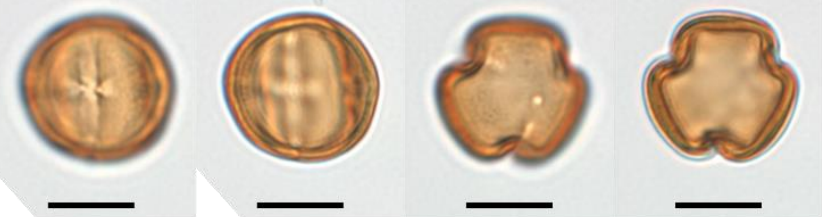


Fabaceae

Plate XXIV

Papilionoideae

Platymiscium

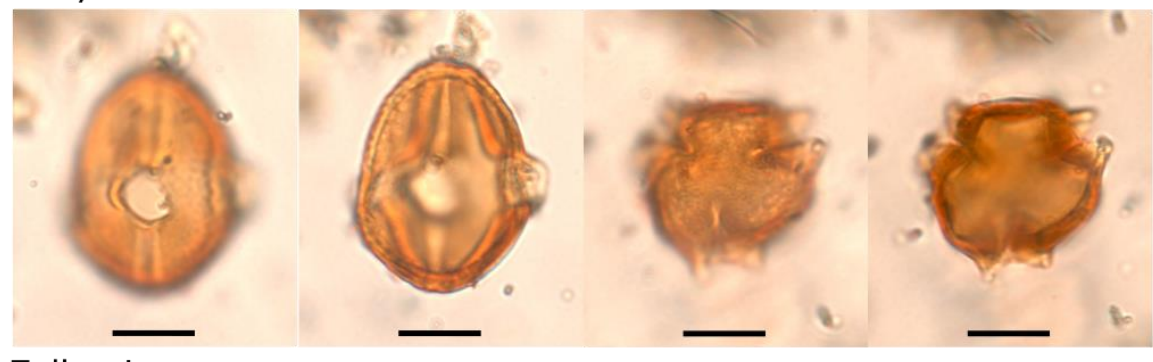

Zollernia

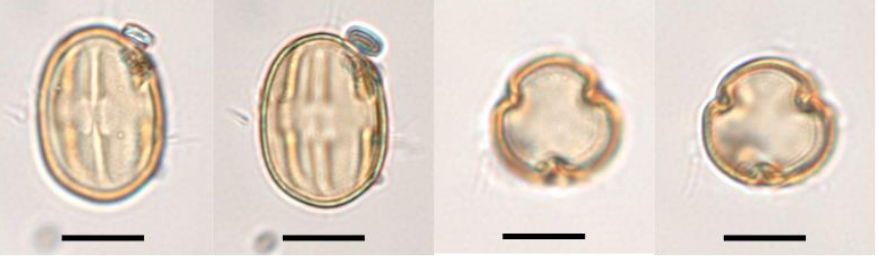

Lamiaceae

Aegiphila??

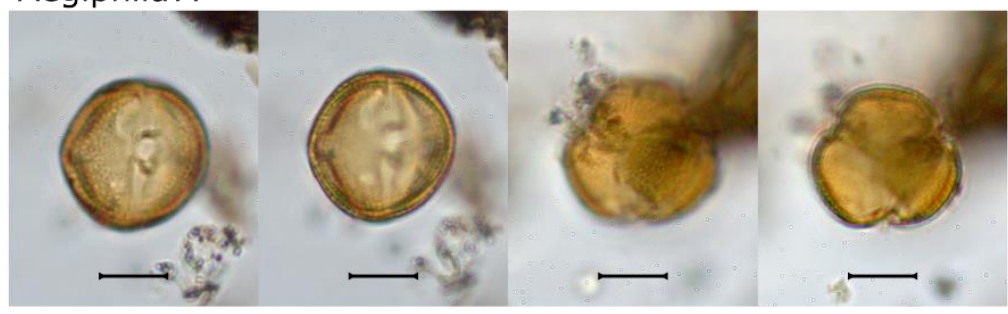

Asterohyptis

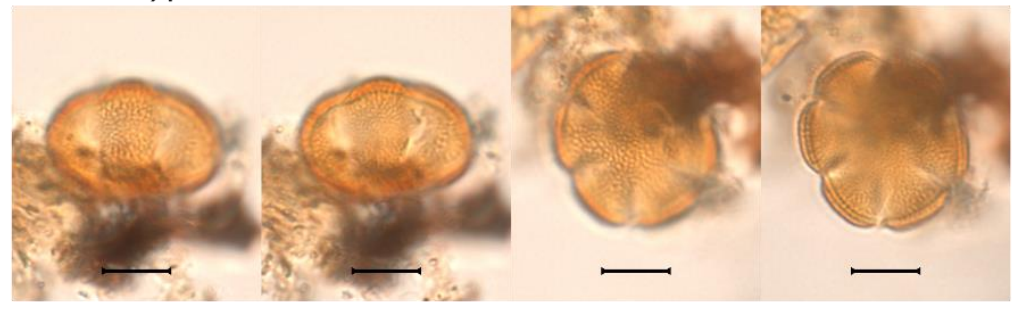

Lecythidaceae

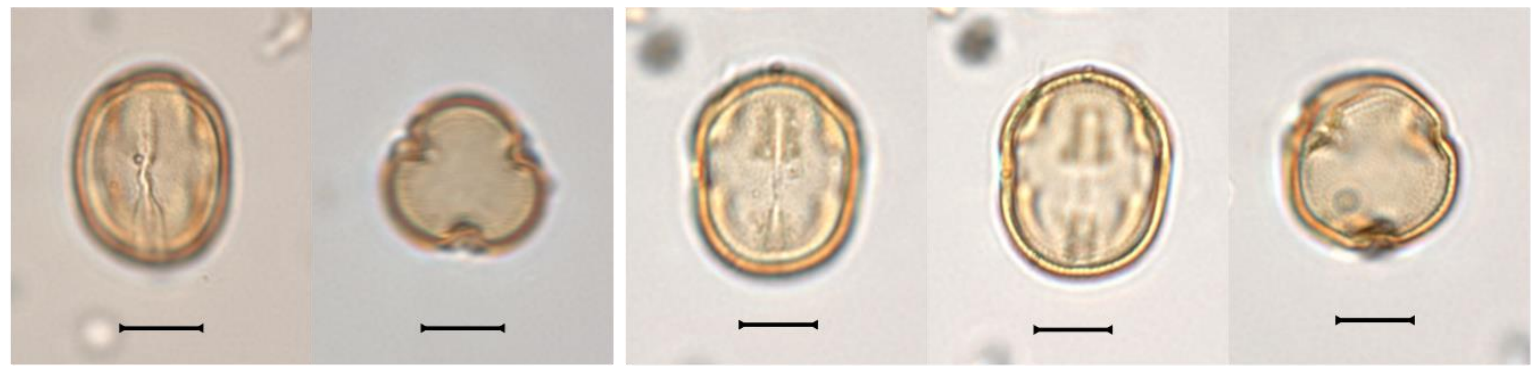




\section{Plate XXV}

Lentibulariaceae

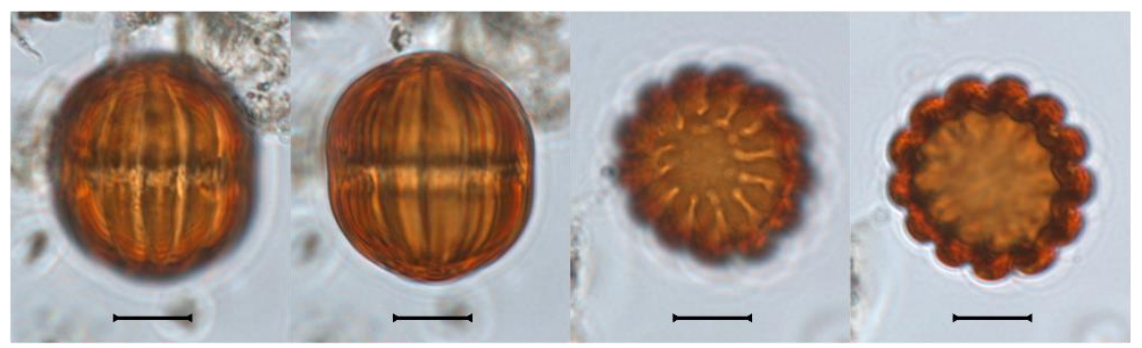

\section{Loasaceae}

Mentzelia

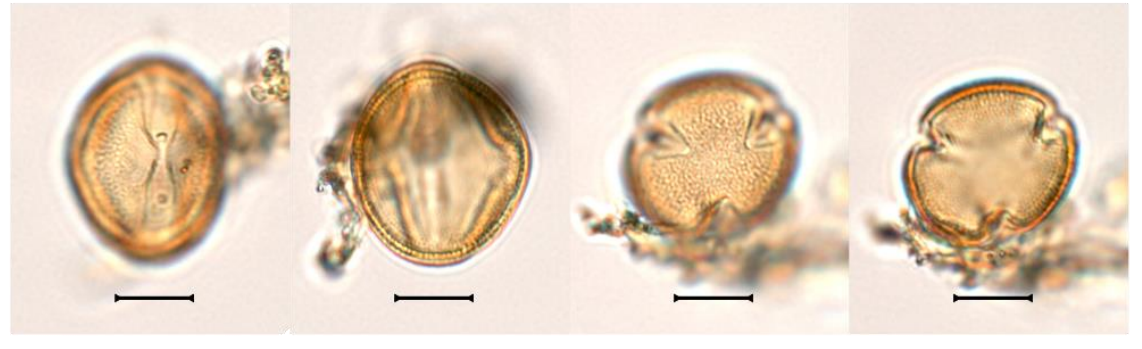

\section{Loranthaceae}

\section{Struthanthus}

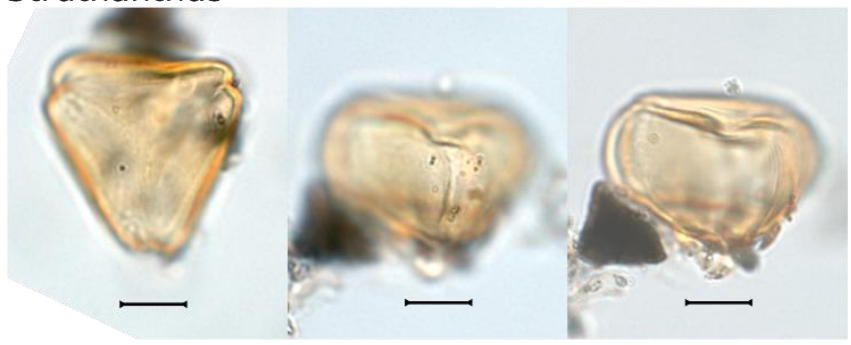

Cladocolea
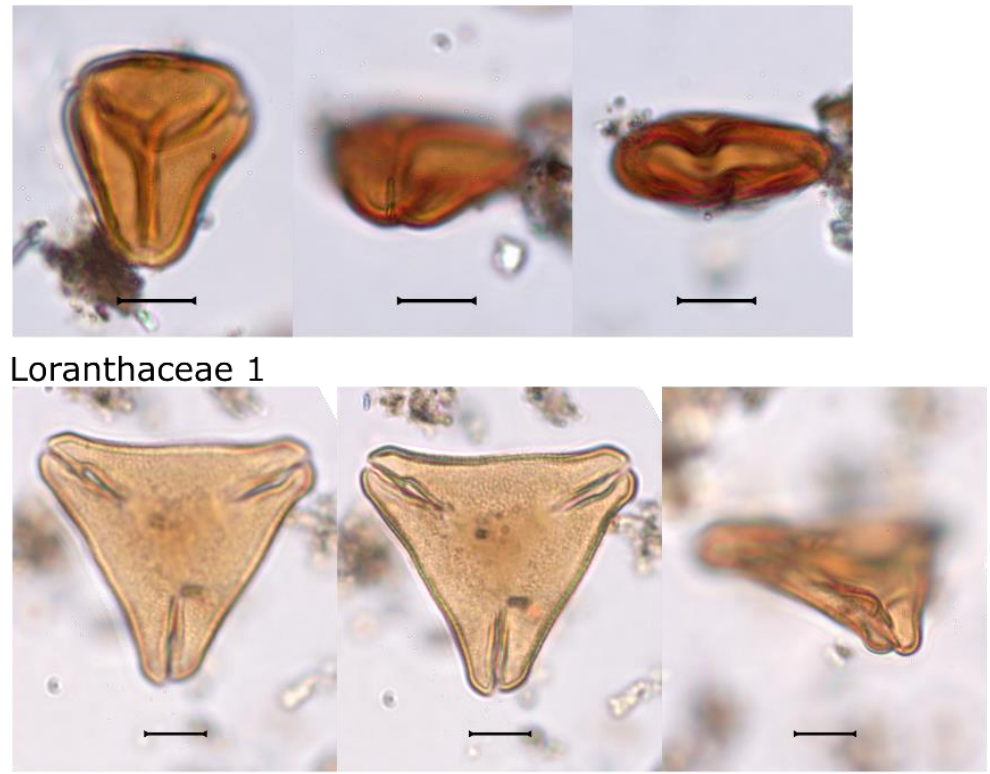


\section{Malpighiaceae}

\section{Plate XXVI}

\section{Banisteriopsis}
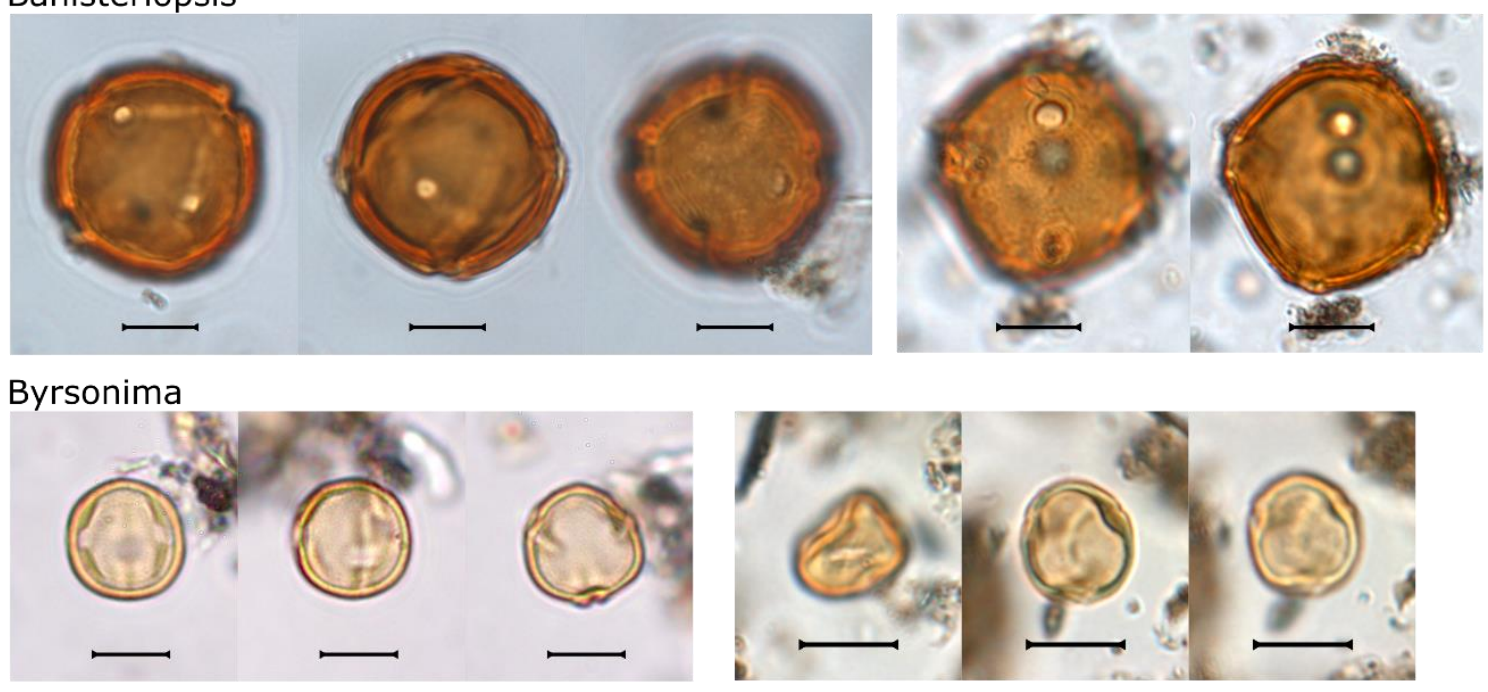

Tetrapterys

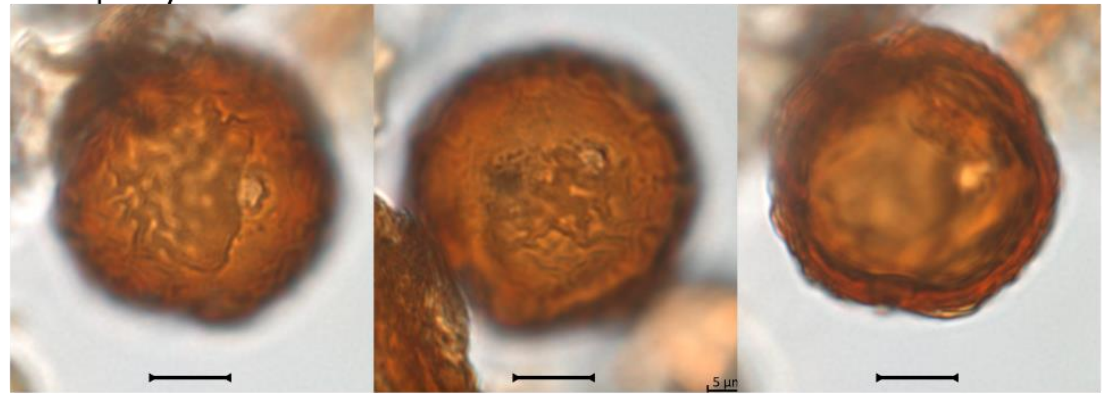

Malpighiaceae
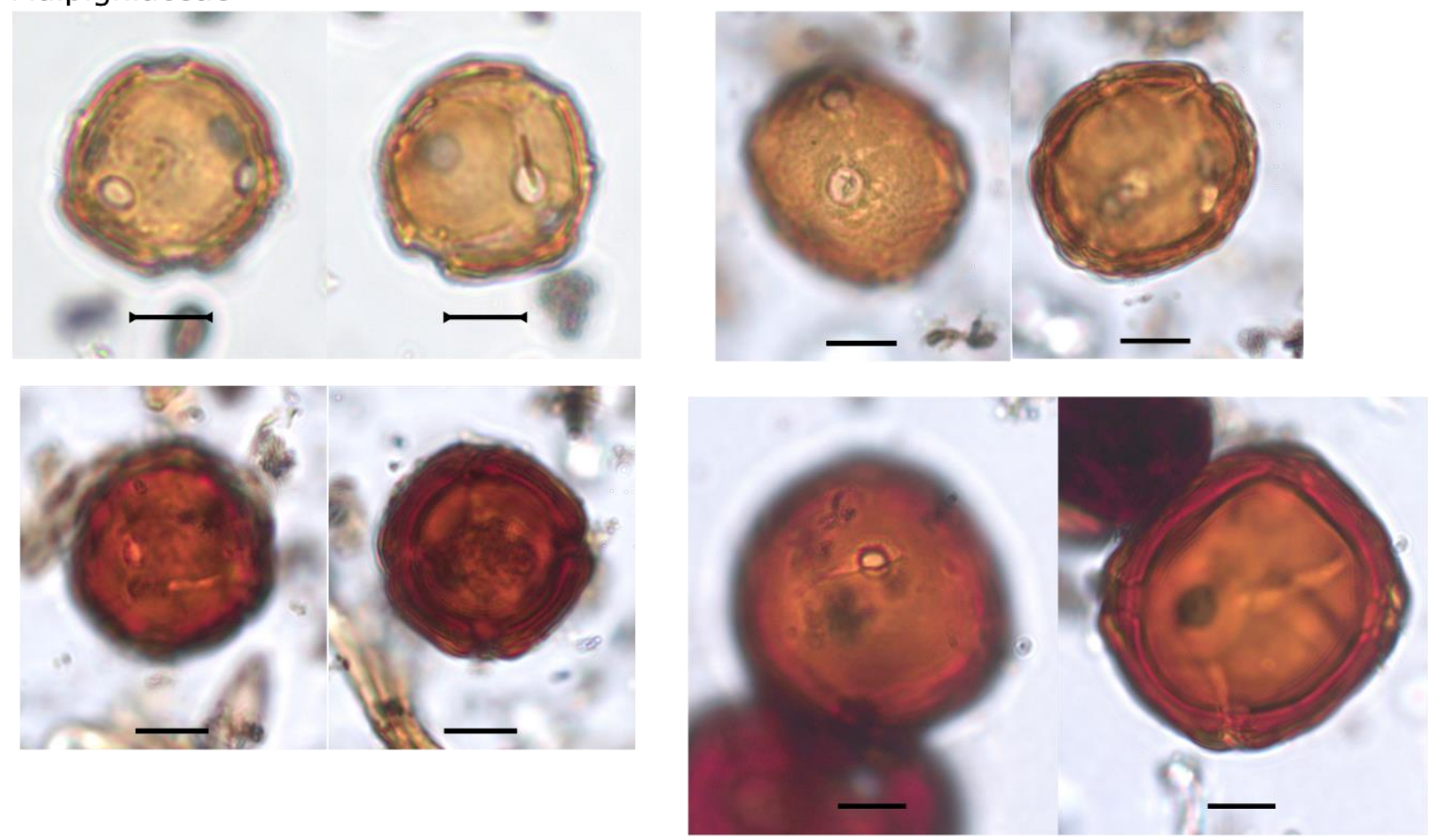
Malvaceae

Plate XXVII

Ayenia

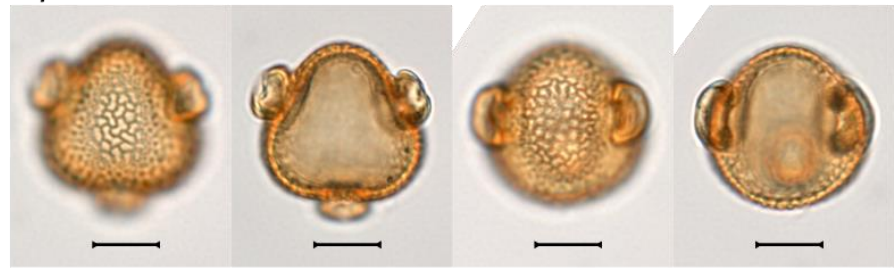

Luehea

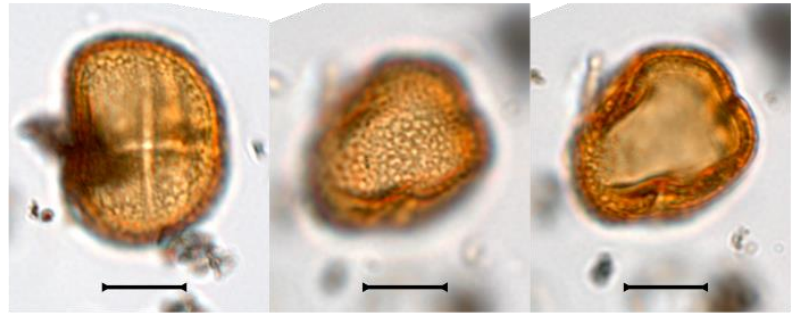

Guazuma
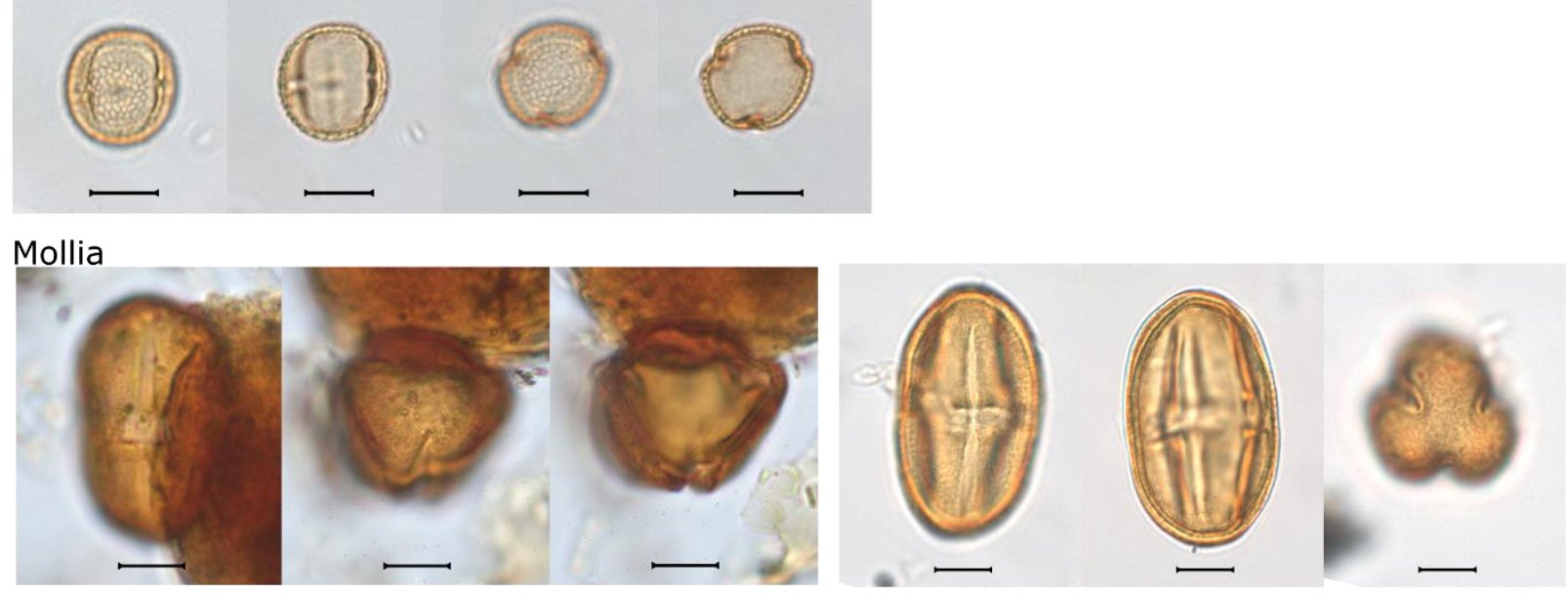

Pseudobombax

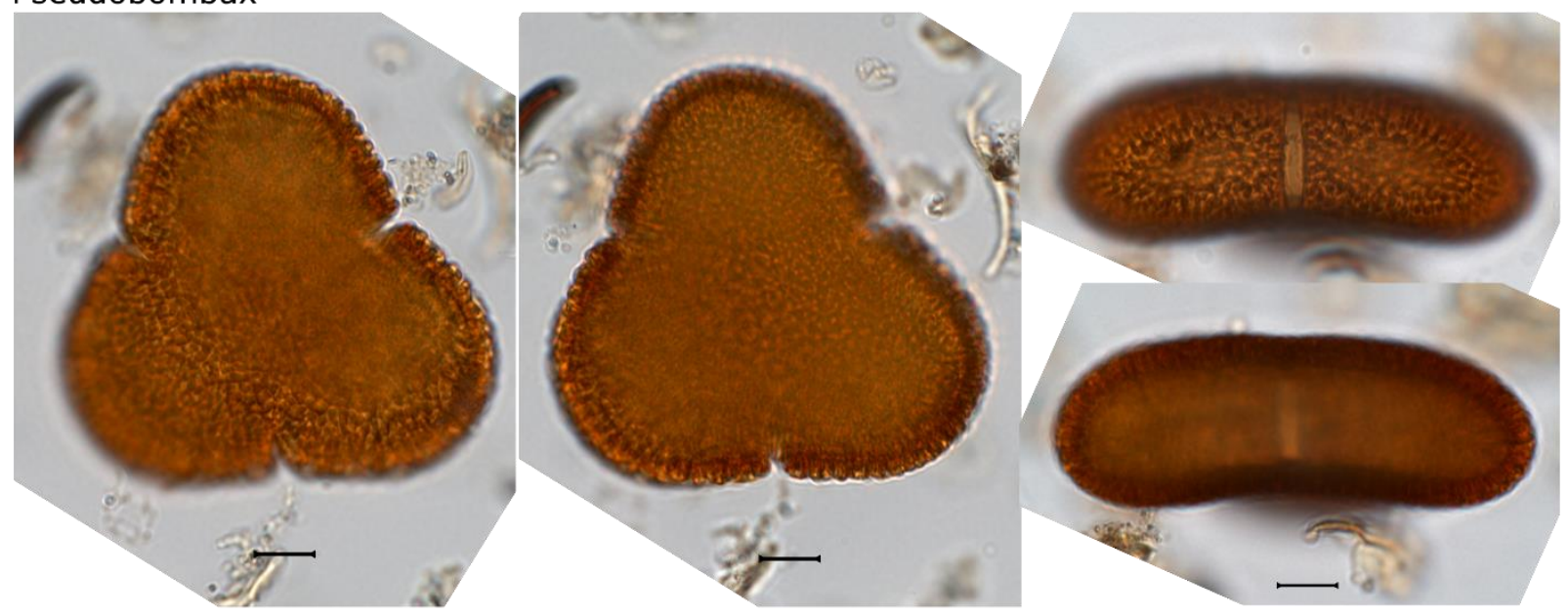


Malvaceae

Plate XXVIII

Scleronema

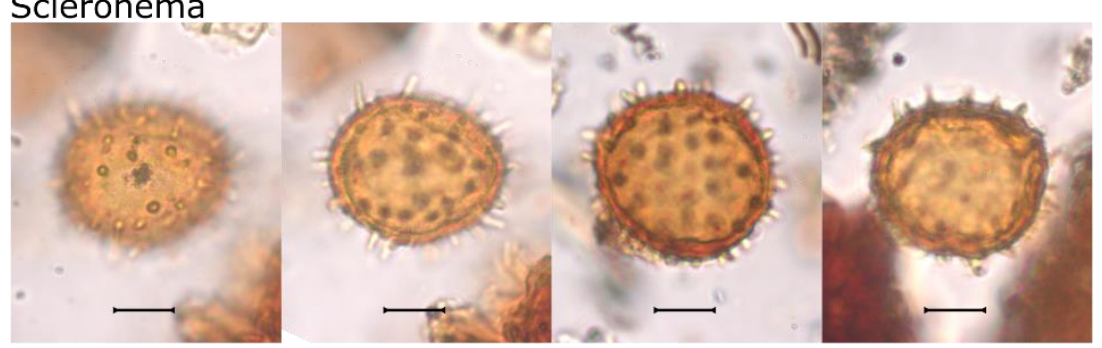

Theobroma

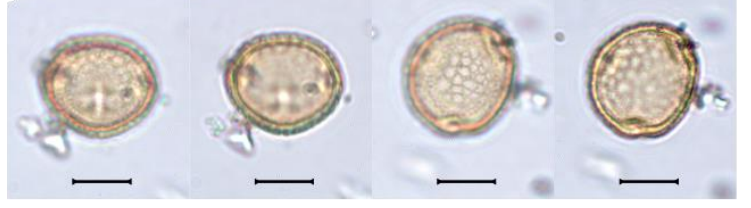

Melastomataceae/Combretaceae
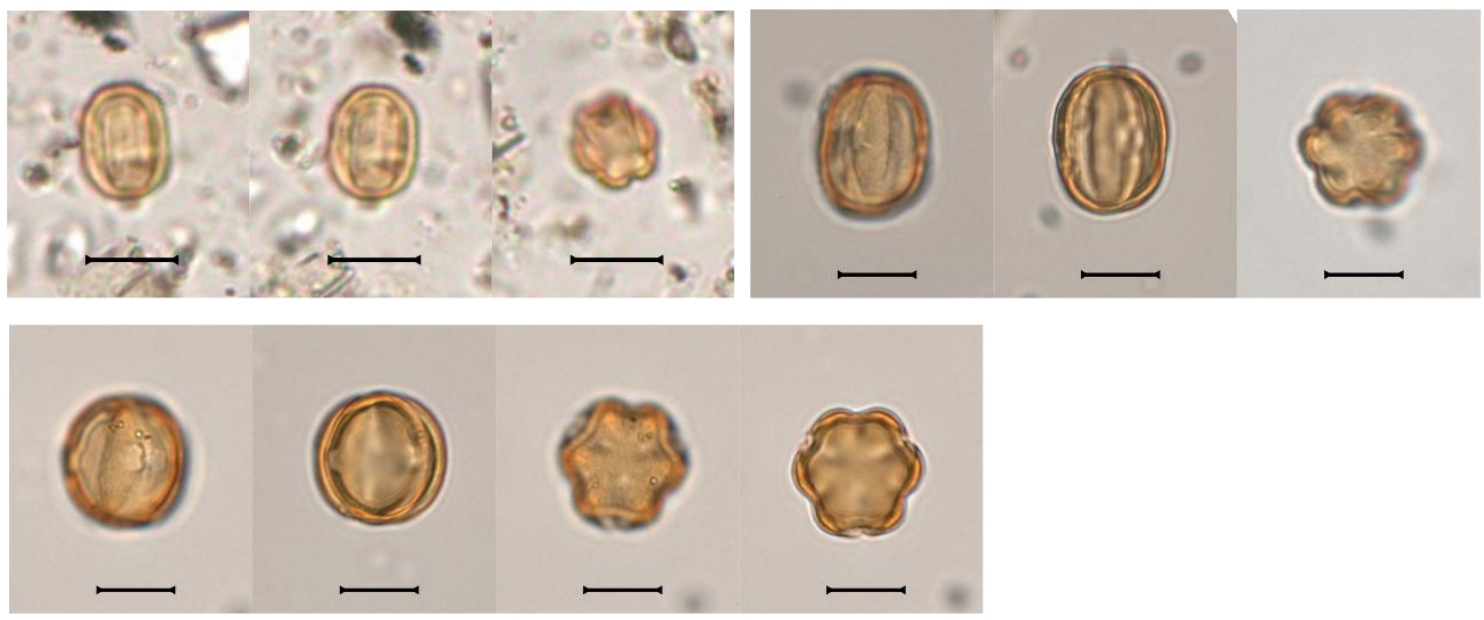

Meliaceae

Cedrela
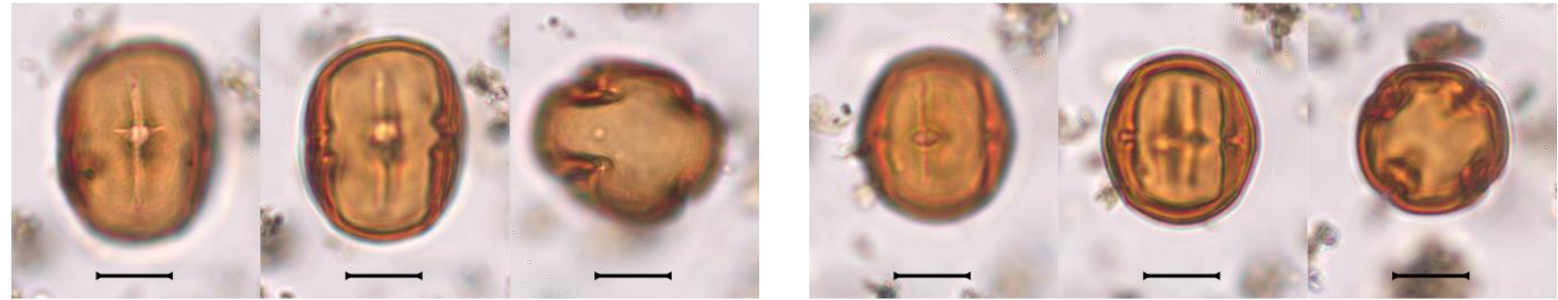

Trichilia

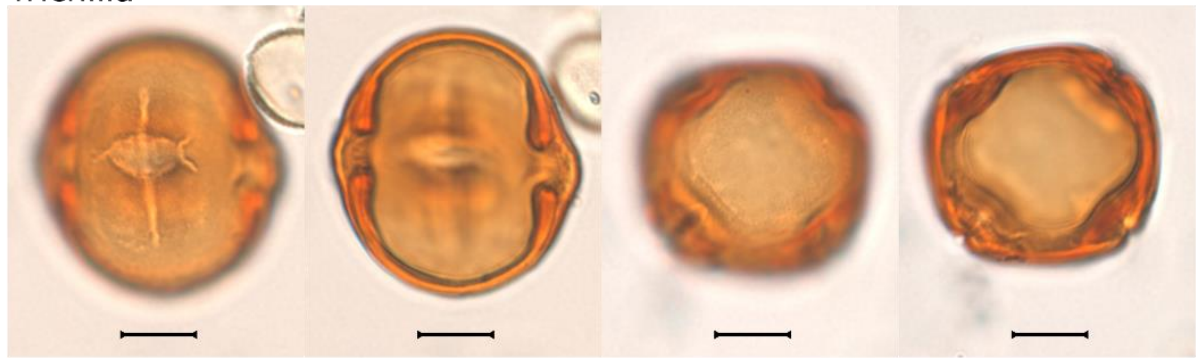


Moraceae
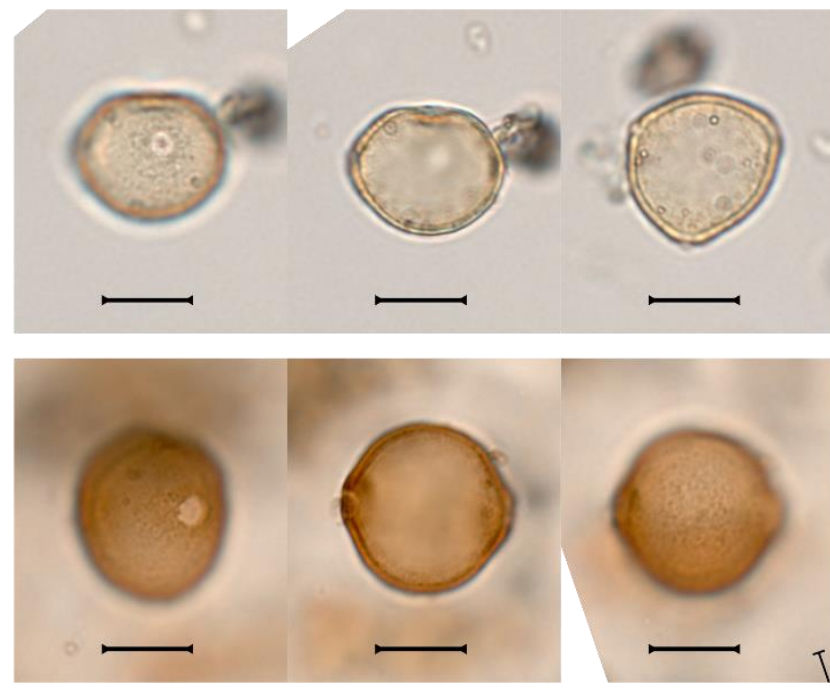

Plate XXIX
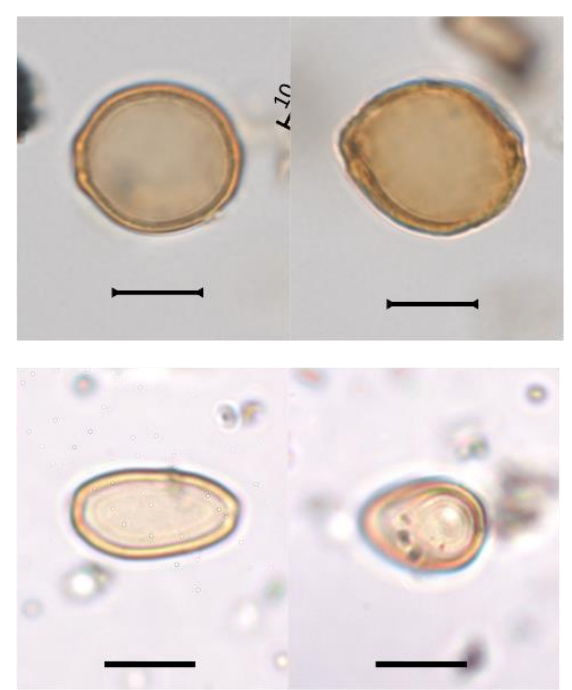

\section{Muntigiaceae}

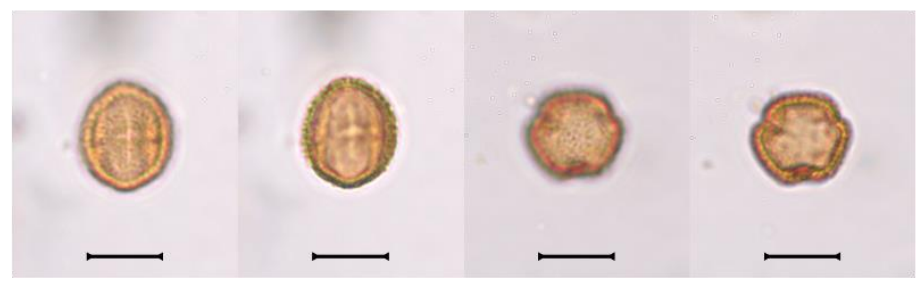

\section{Myricaceae}

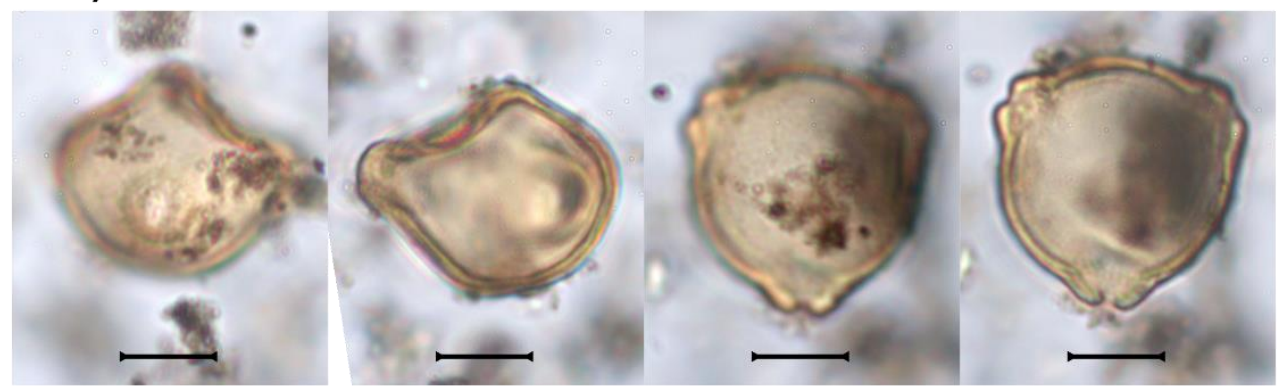

\section{Myristicaceae}

Virola/Iryanthera
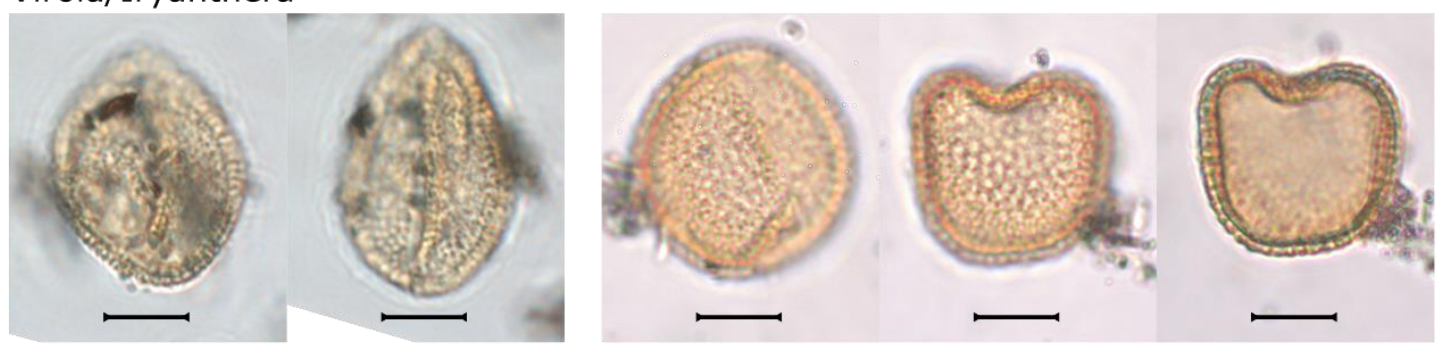
Myrtaceae

Plate XXX

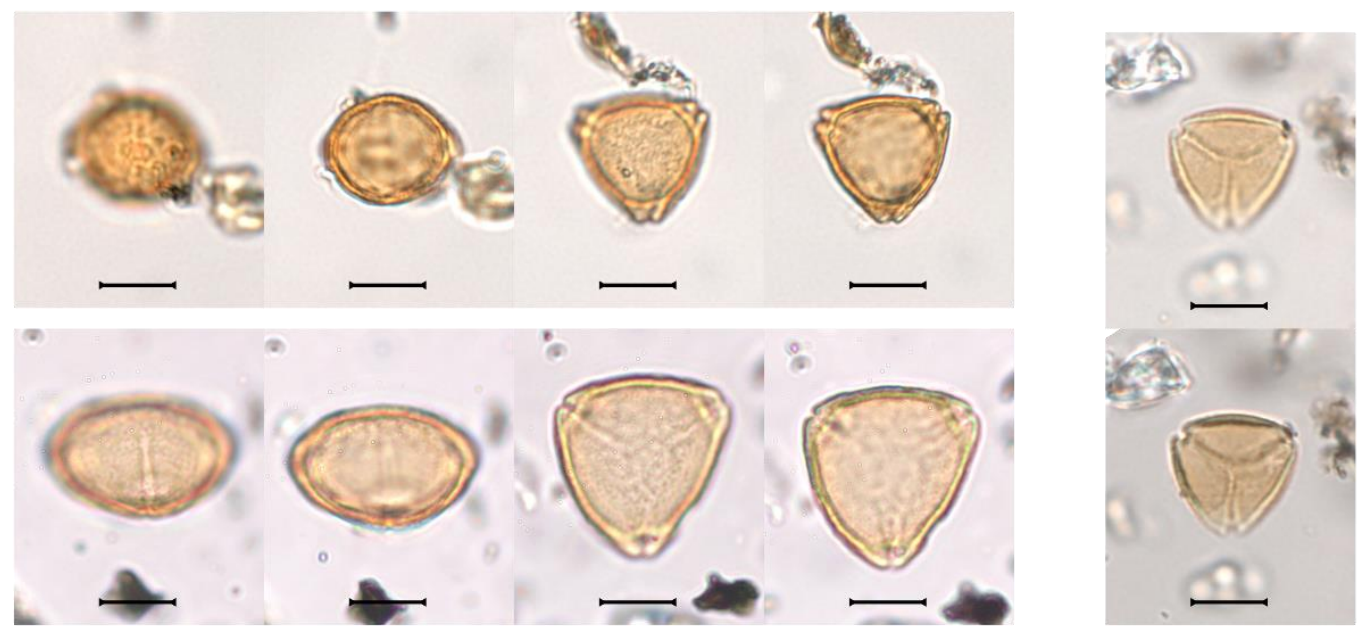

Ochnaceae

Ouratea

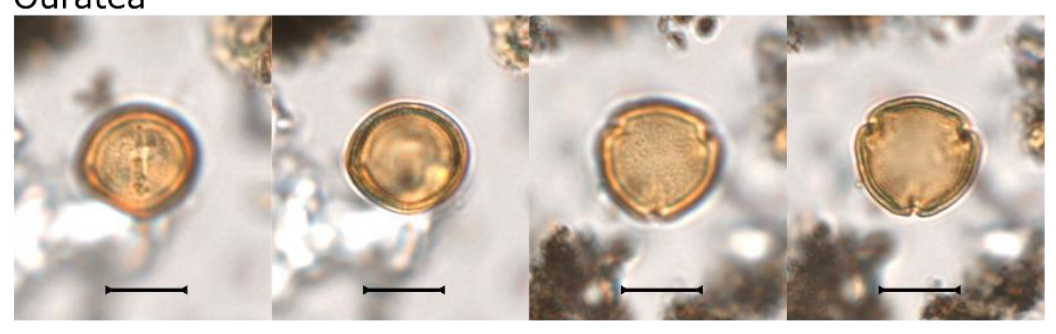

Olacaceae

Chaunochiton

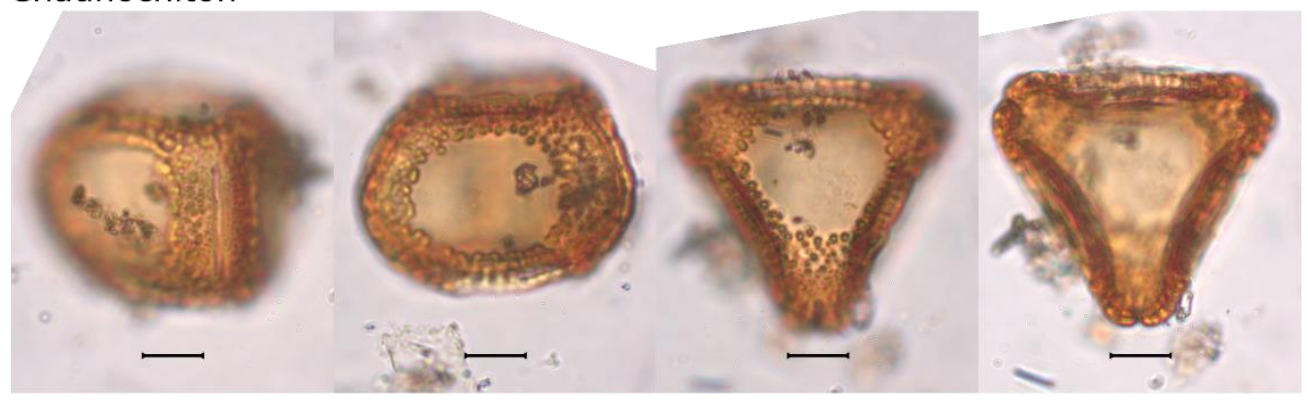

Dulacia

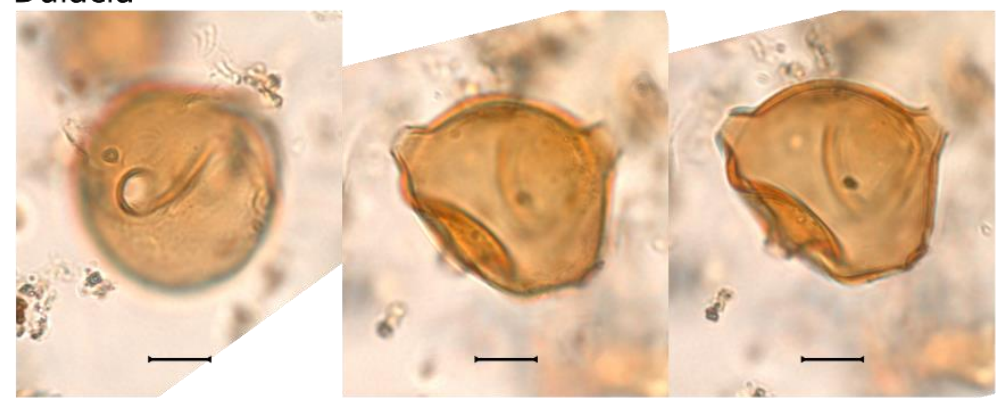



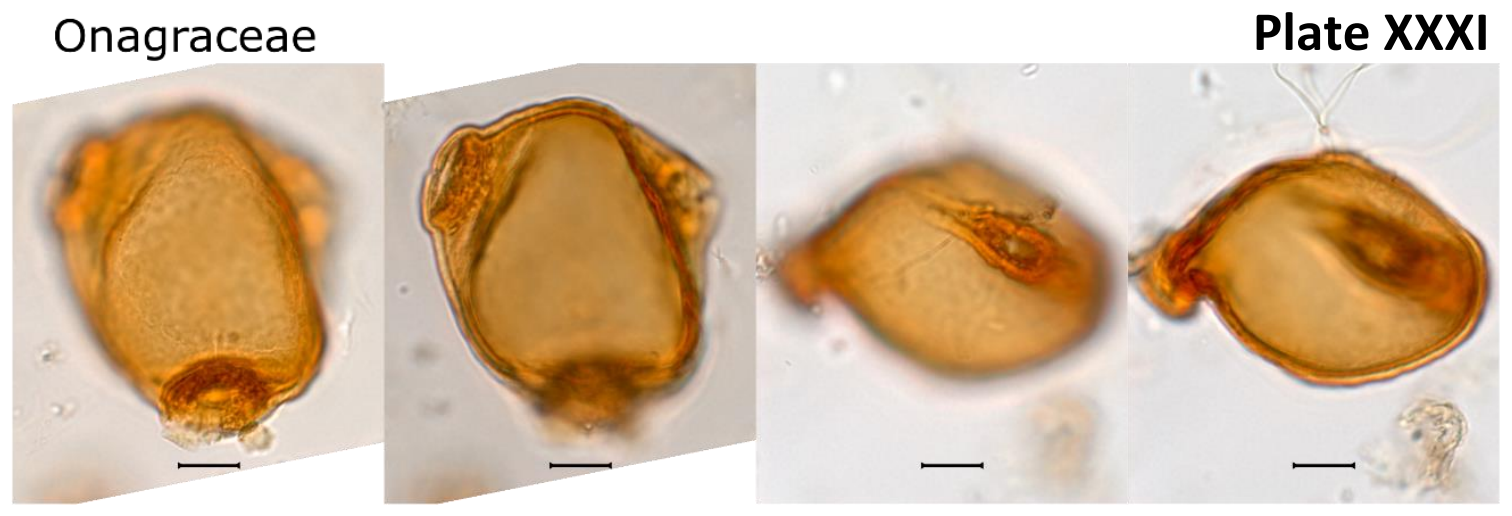

\section{Passifloraceae}

\section{Turnera}
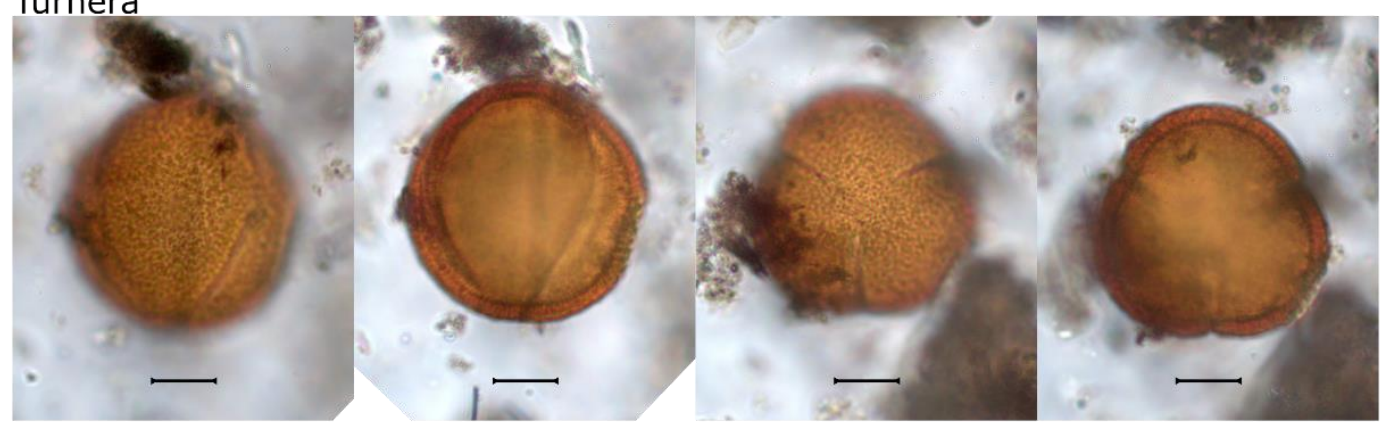

\section{Phyllanthaceae}

Amanoa

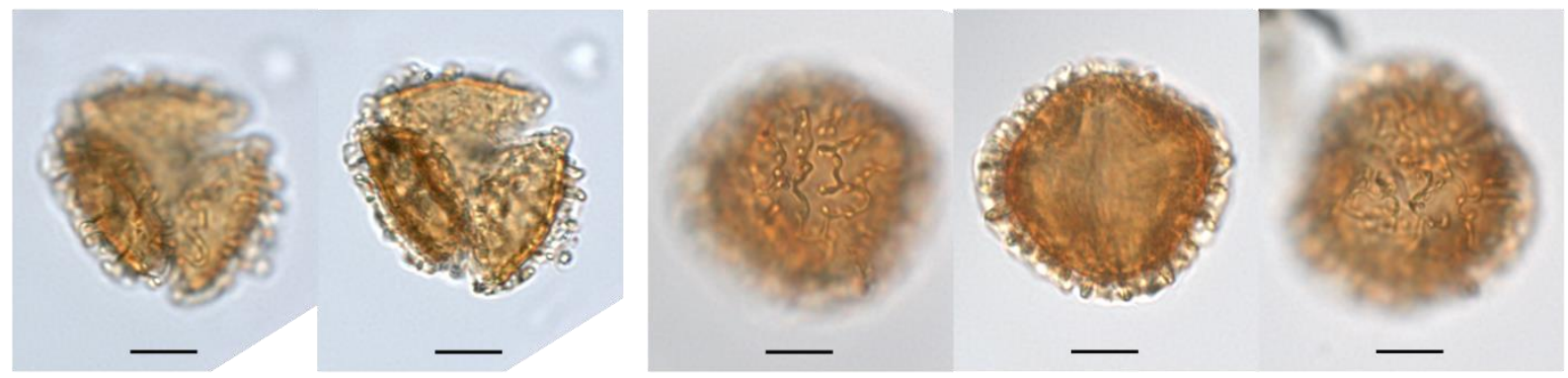

Phyllanthus

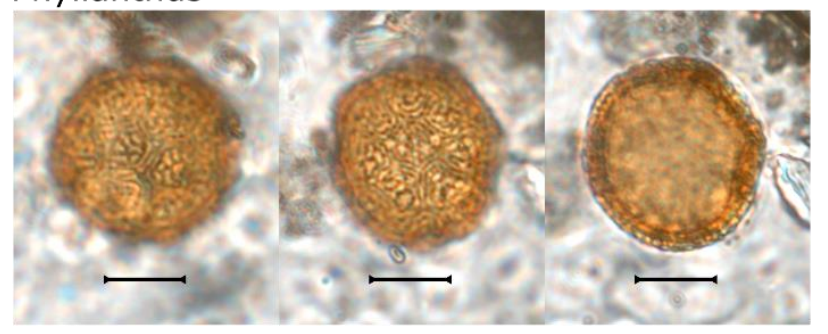

Hieronyma

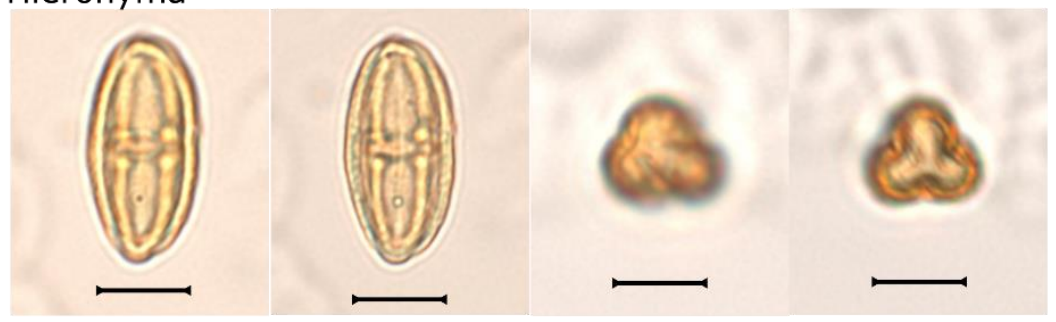


Phytolaccaceae

Microtea

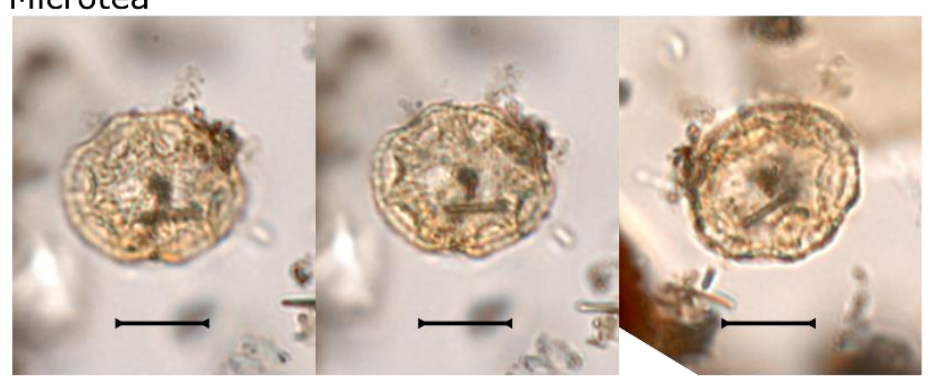

Picrodendraceae

Piranhea
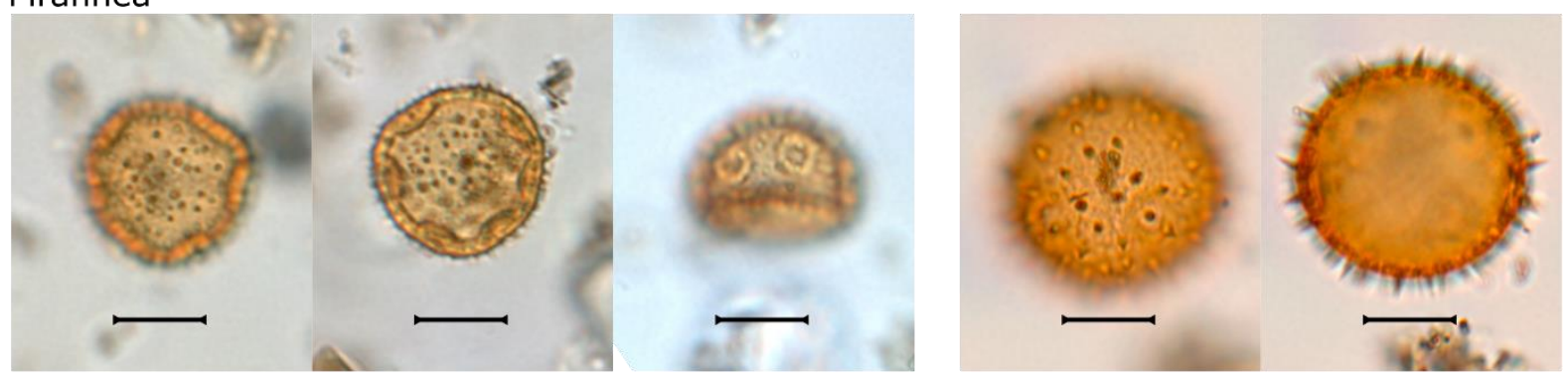

\section{Piperaceae}

Piper

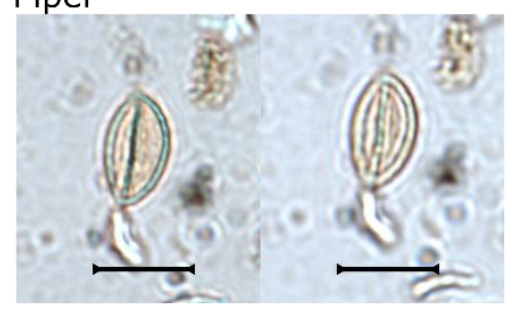

\section{Plantaginaceae}

Sairocarpus

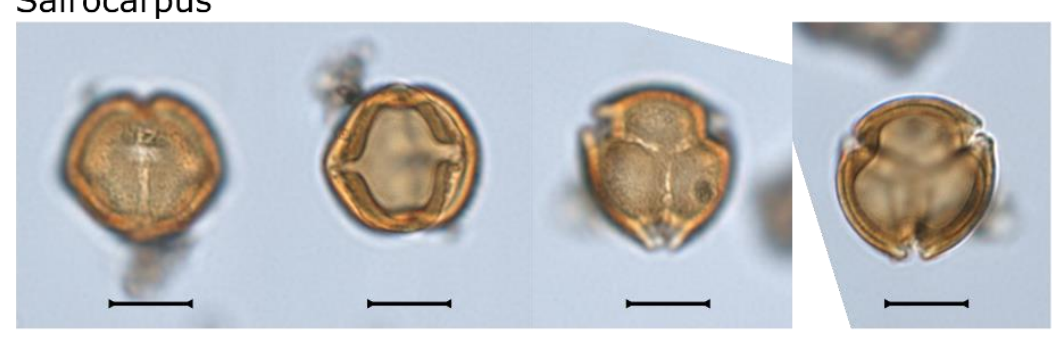

\section{Poaceae}
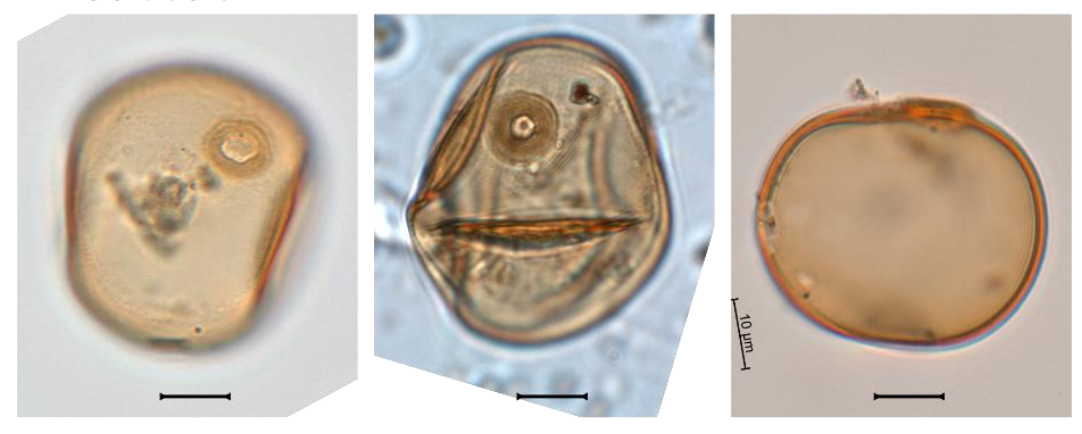
Podocarpaceae

Plate XXXIII

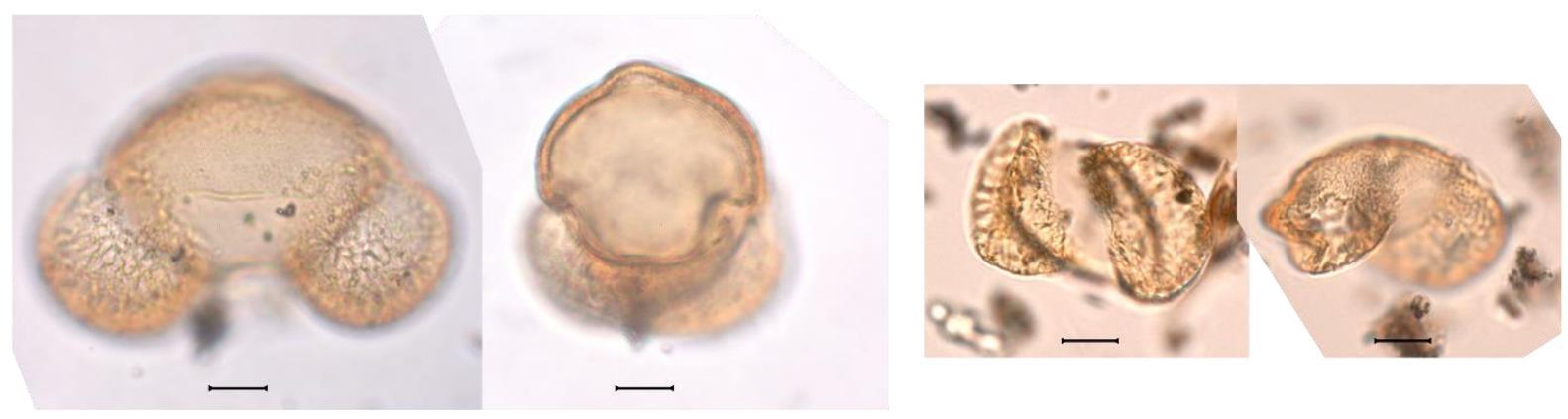

Polemoniaceae

Leptodactylon?

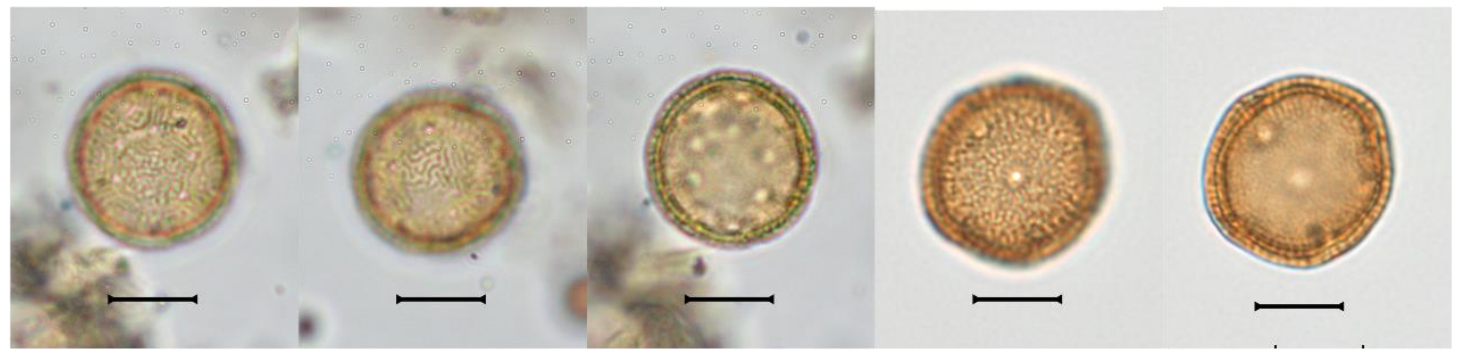

Polygalaceae

Badiera

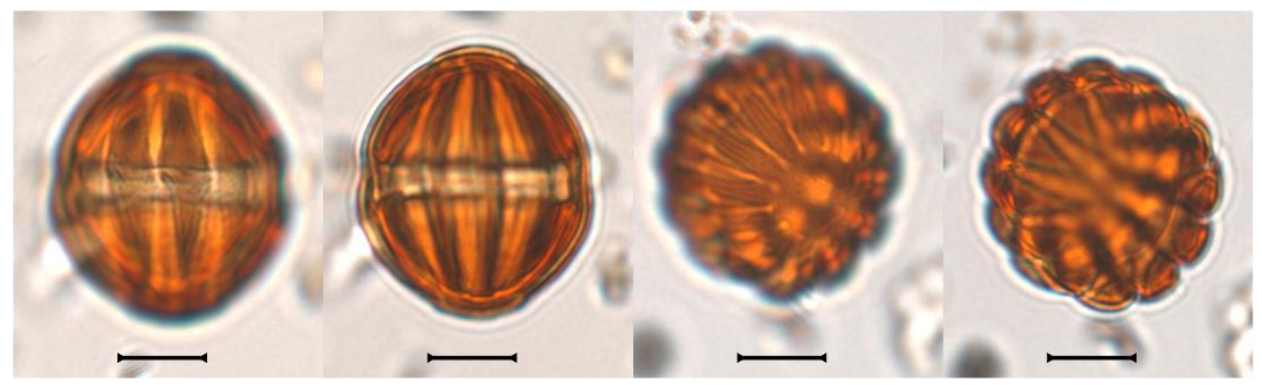

Securidaca

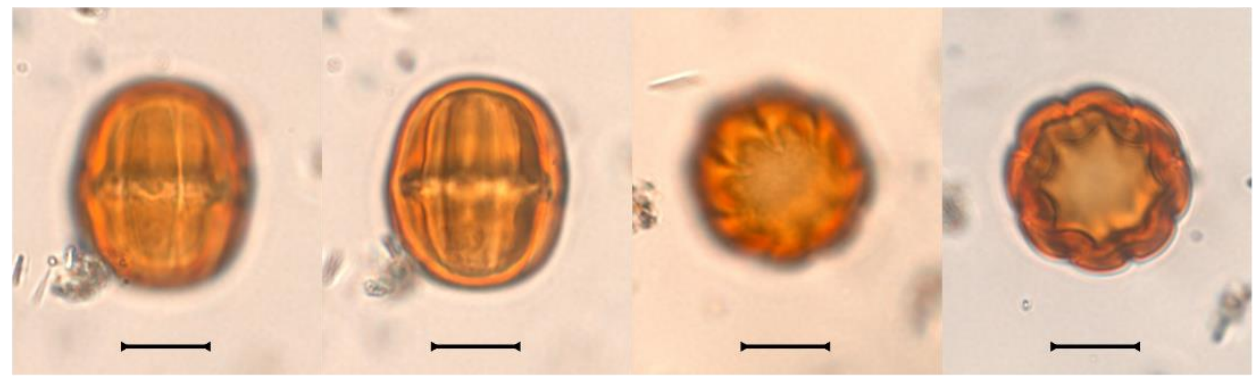


Polygonaceae

Plate XXXIV

Symmeria

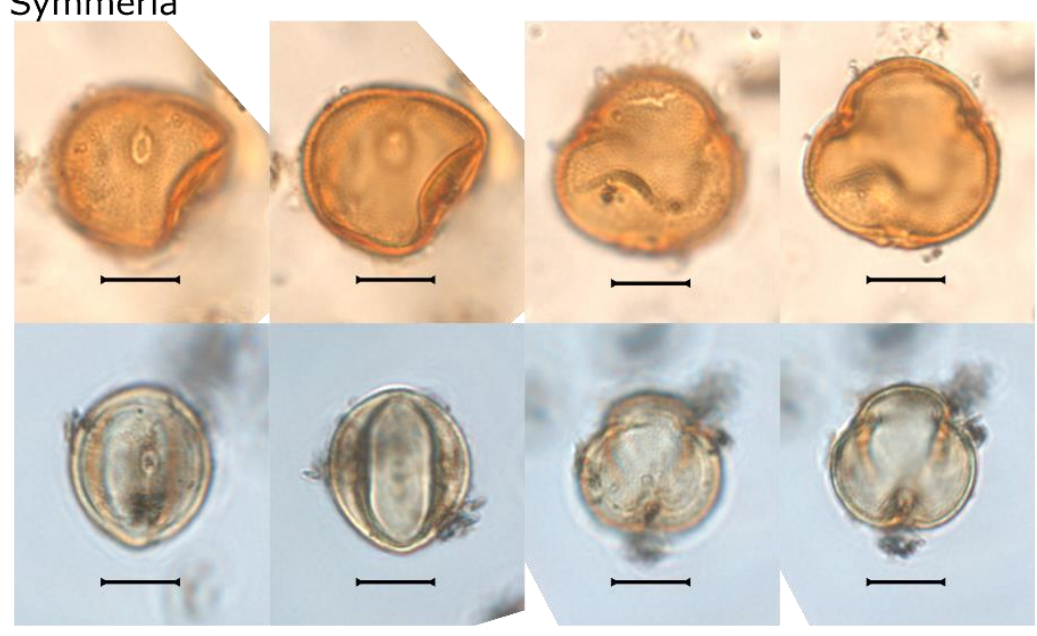

Triplaris

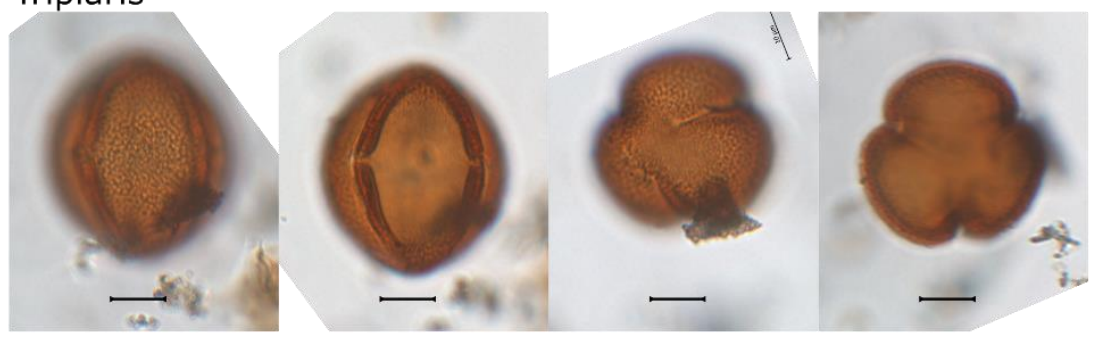

\section{Pontederidaceae}

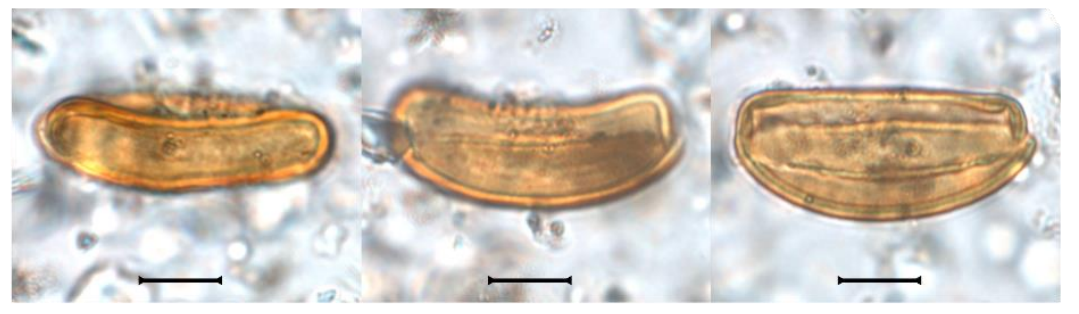

Primulaceae

Myrsine

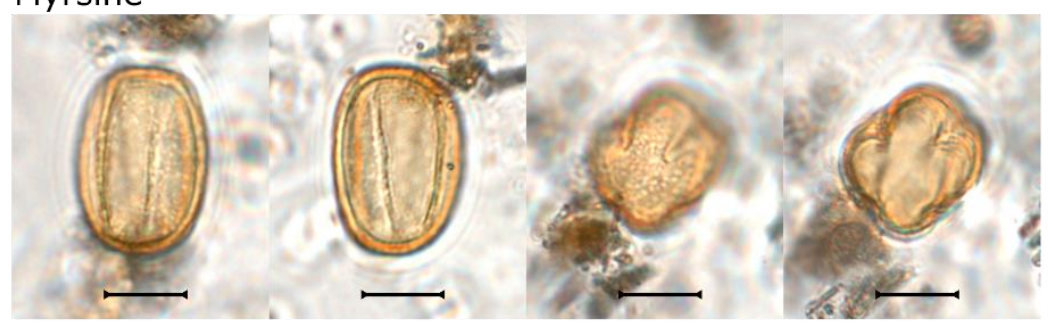

Anagallis?

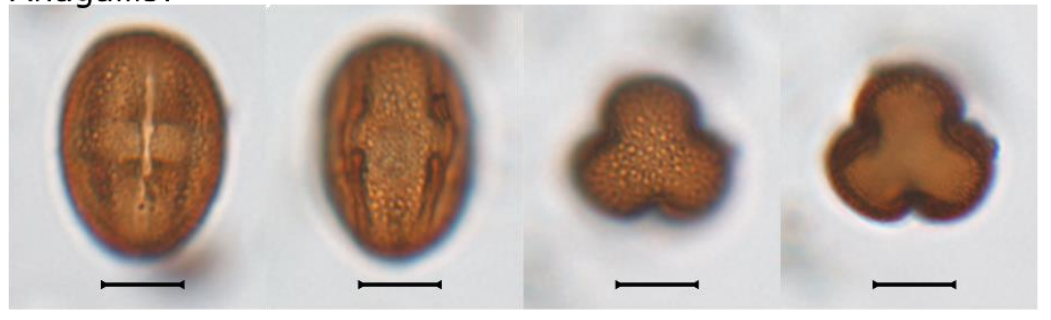


Proteaceae

Euplassa

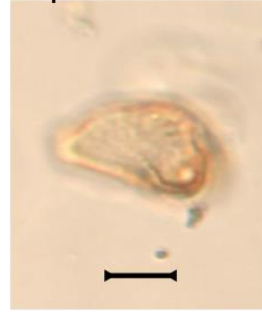

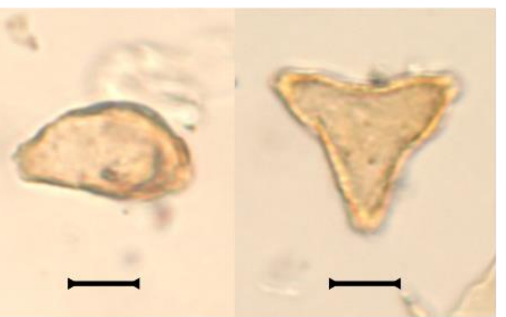

Roupala

\section{Plate XXXV}

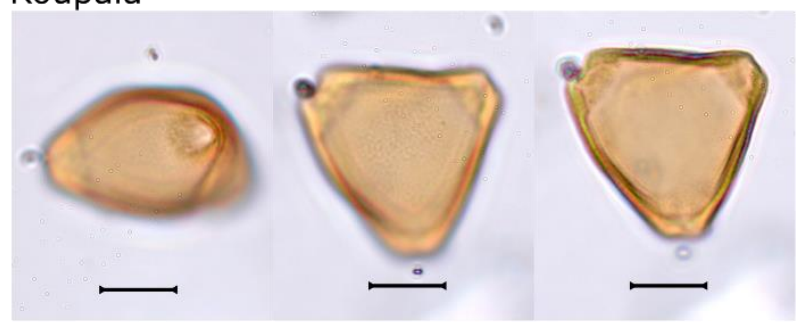

\section{Panopsis}

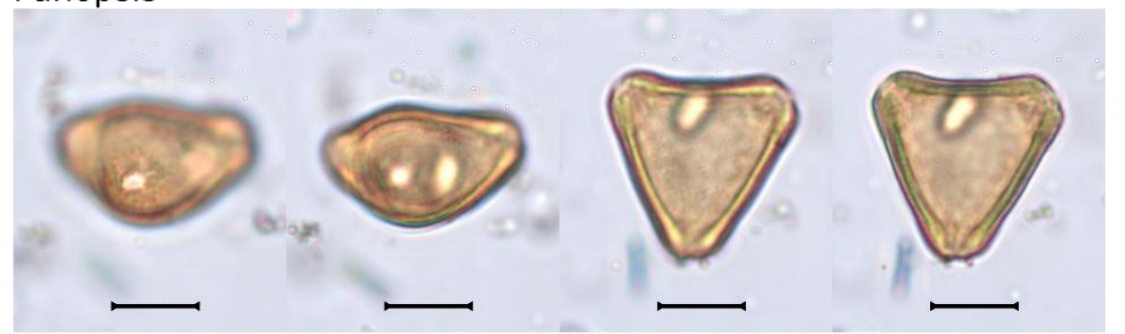

Rhammanaceae

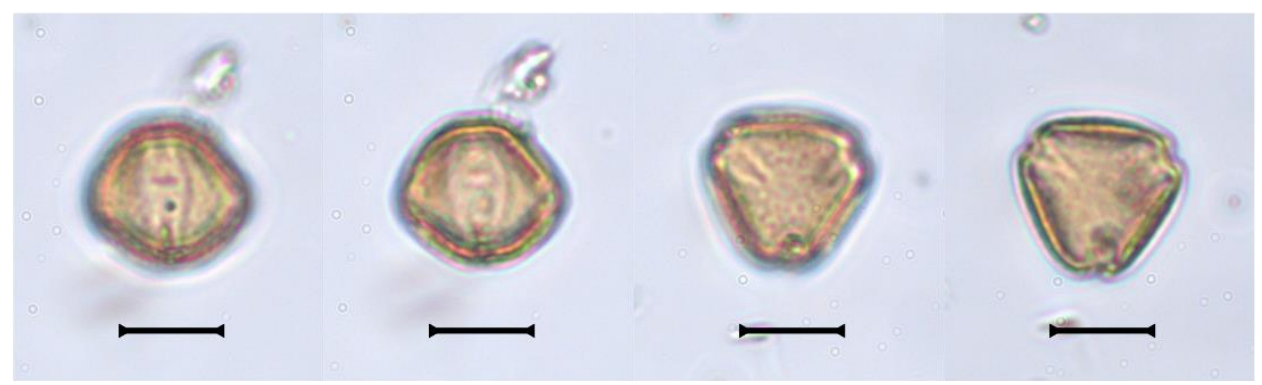

\section{Rubiaceae}

Allenanthus

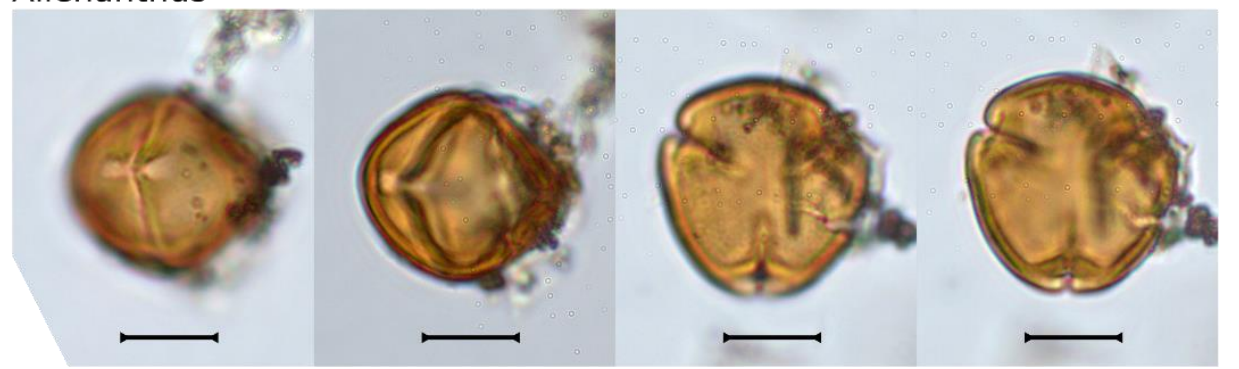

Alseis

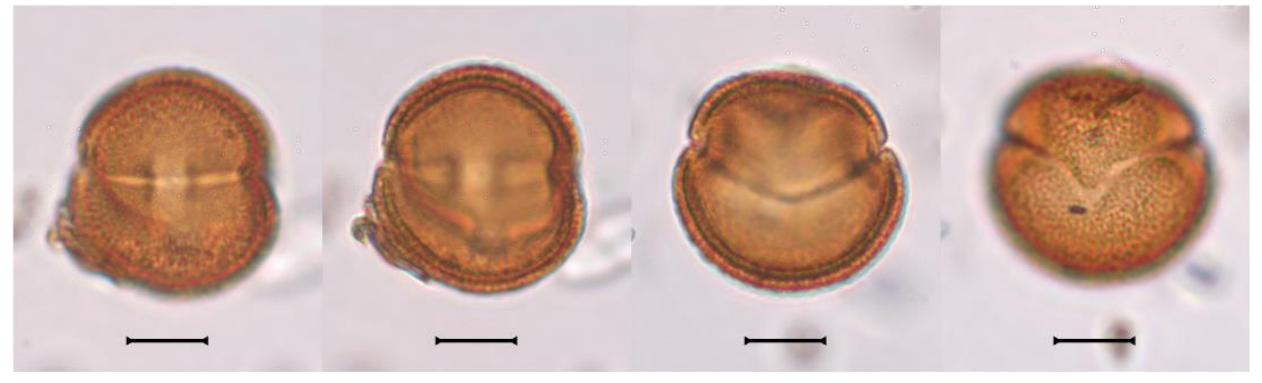


Rubiaceae

Plate XXXVI

Alibertia
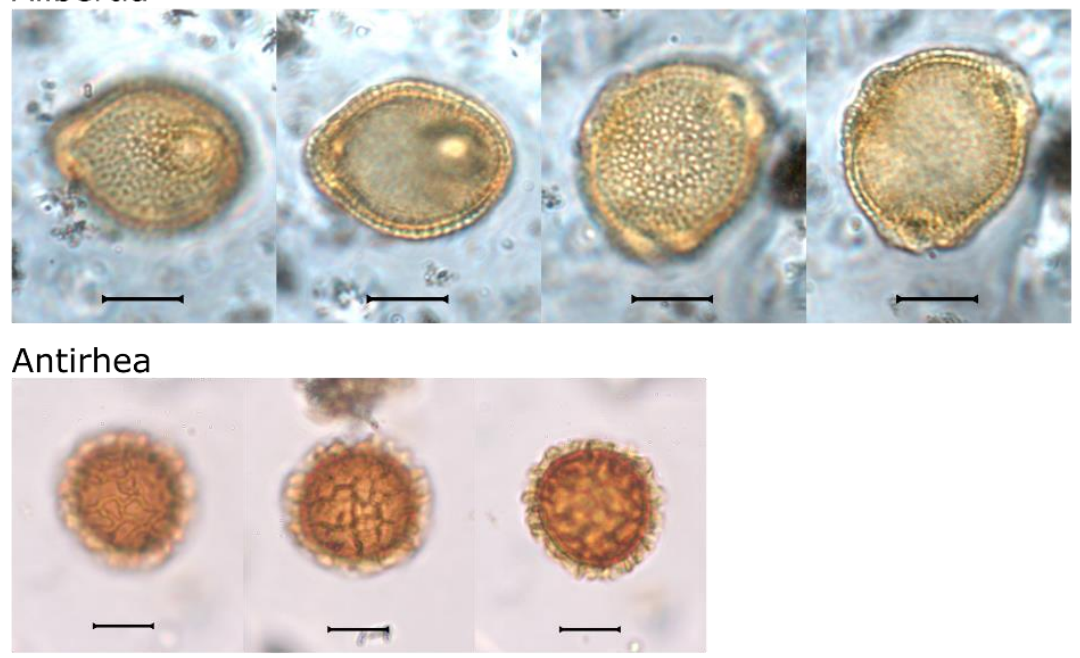

Borreria

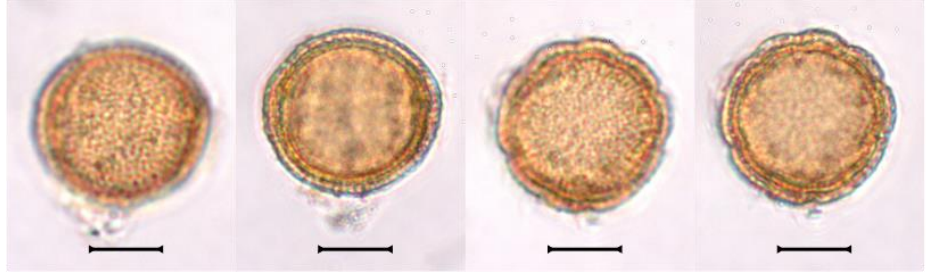

Bothriospora

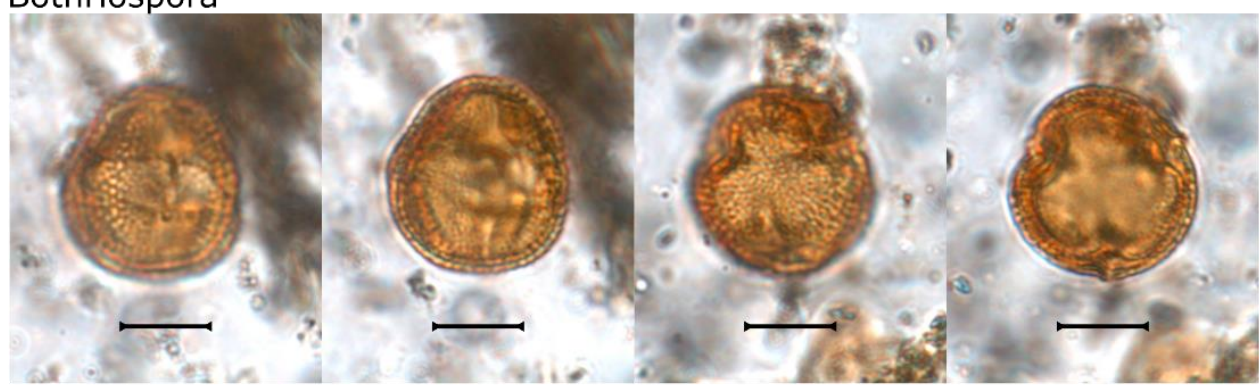

Chomelia

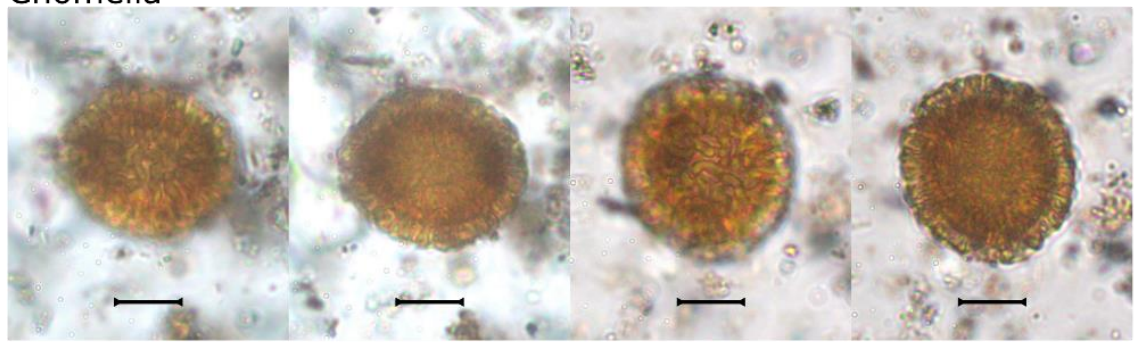

Chiococca?

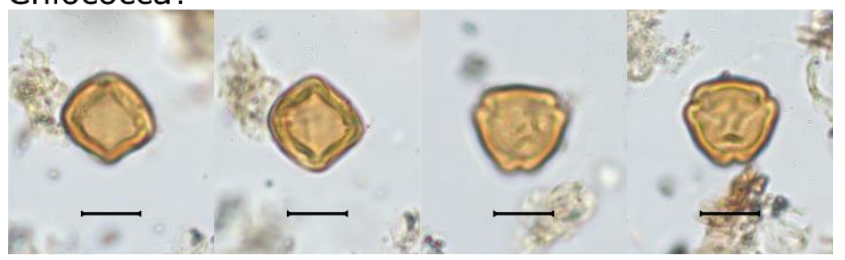


Rubiaceae

Plate XXXVII

Duroia

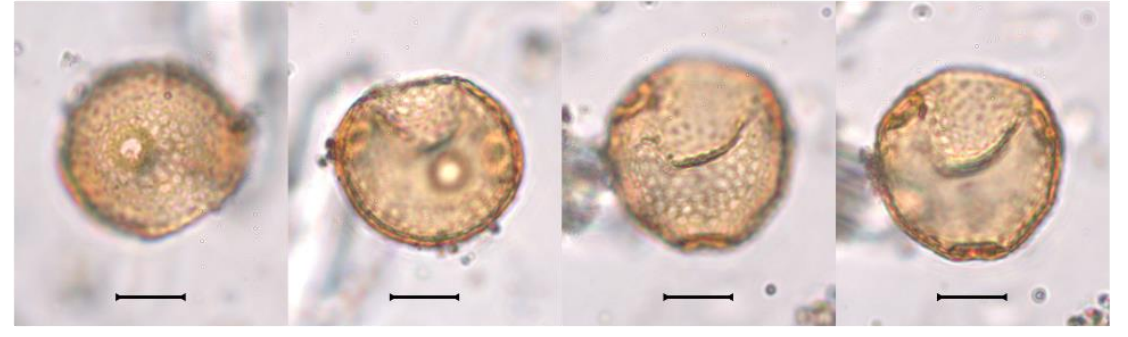

Faramea
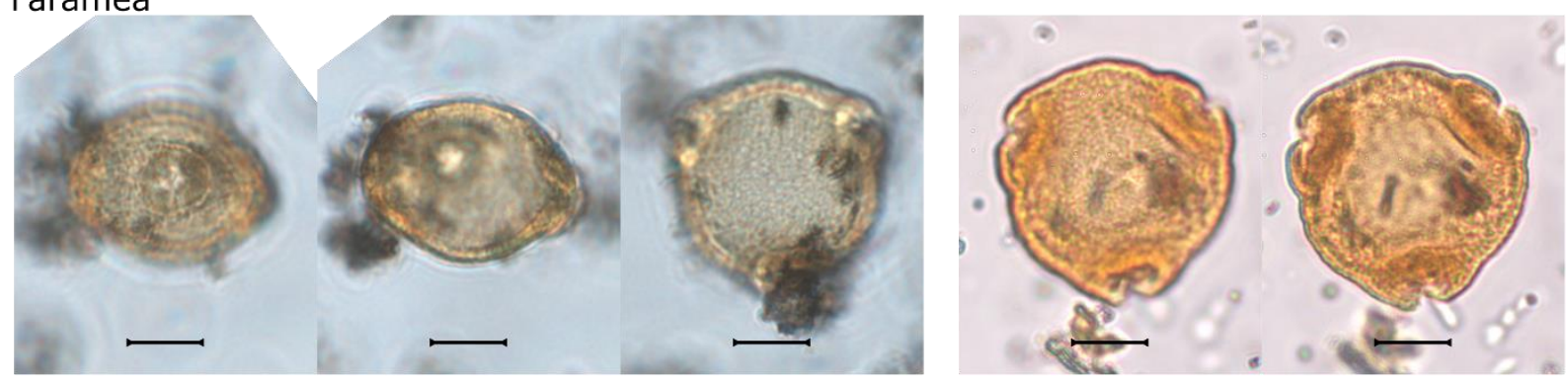

Ferdinandusa?/Genipa?
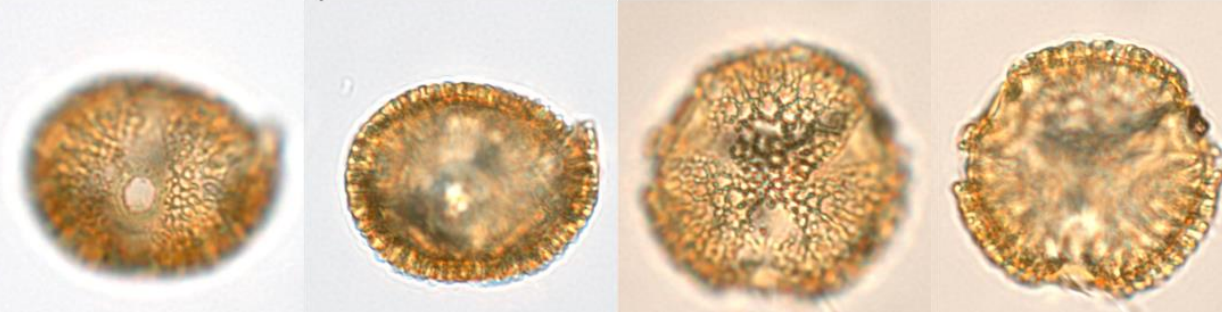

Genipa

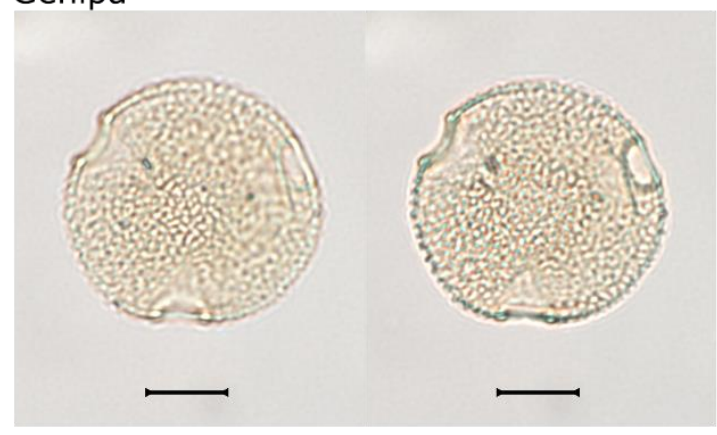

Hedyotis

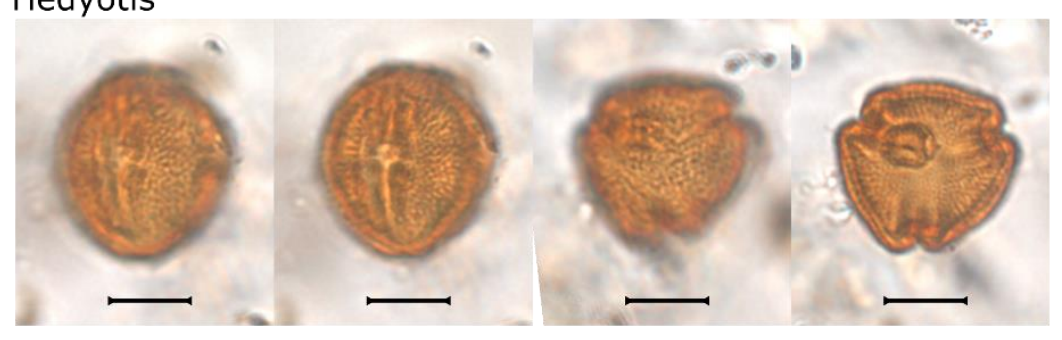


Rubiaceae

Plate XXXVIII

Houstonia

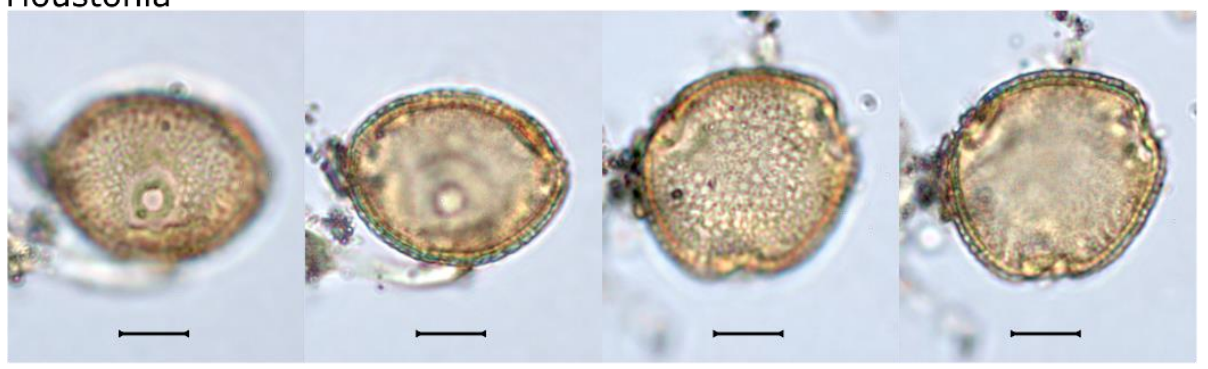

Stachyarrhena

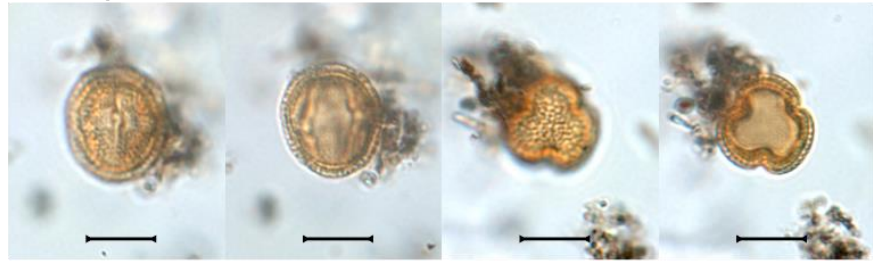

Rutaceae

Zanthoxylum

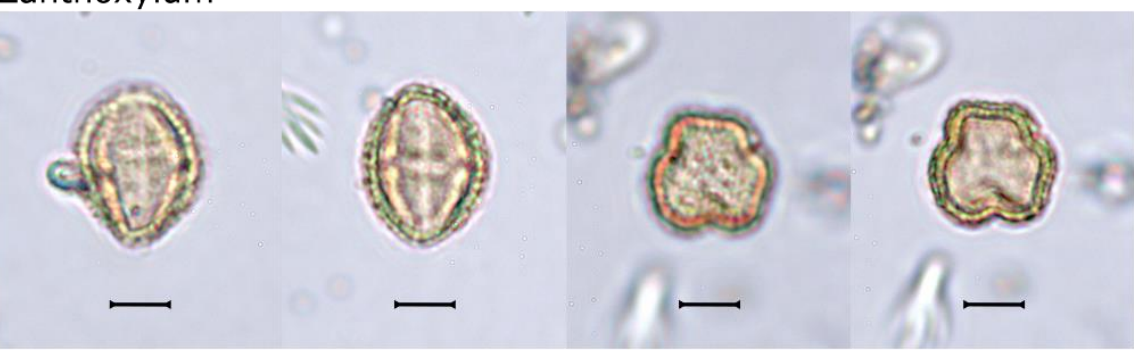

\section{Esenbeckia?}

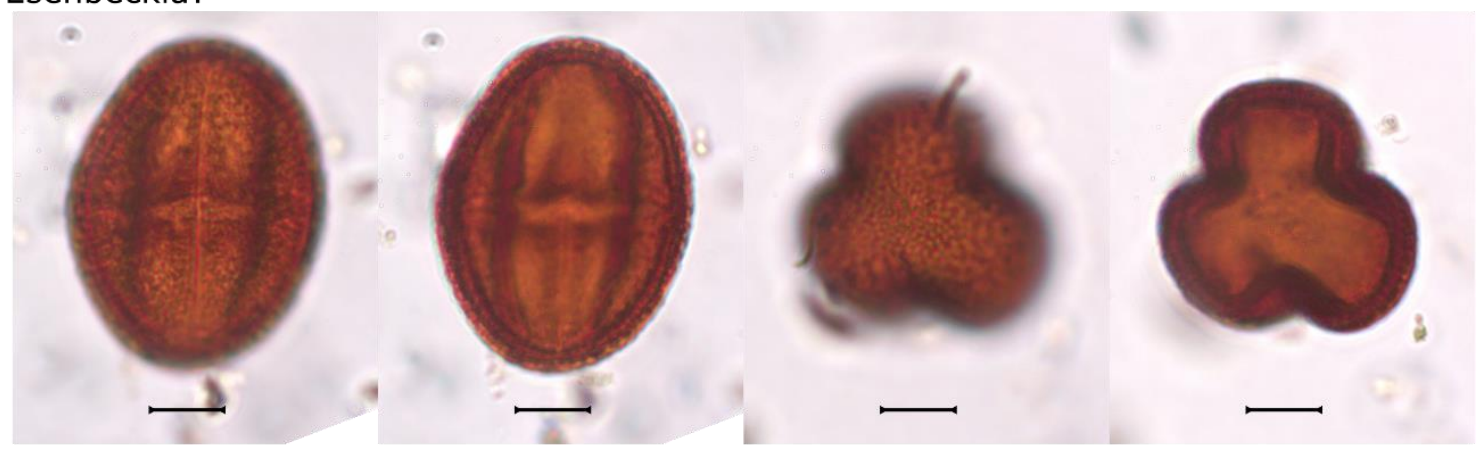

Citrus
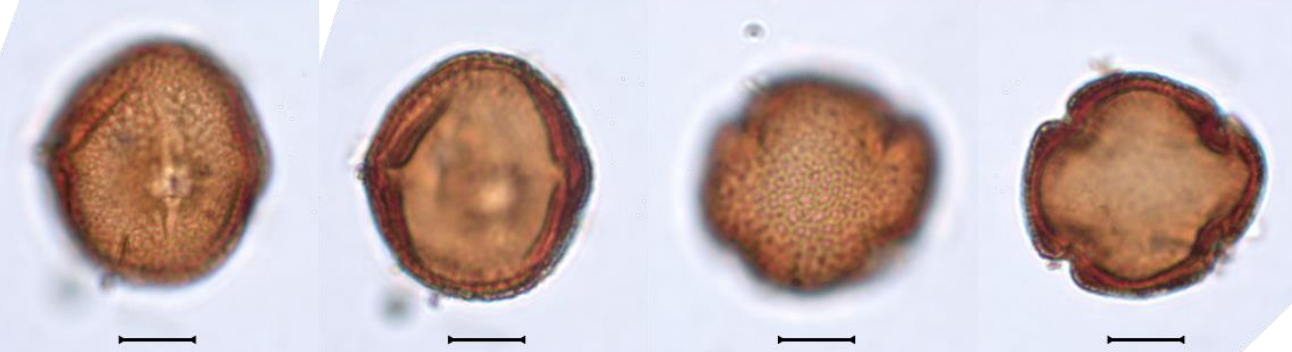
Salicaceae

Plate XXXIX

Homalium
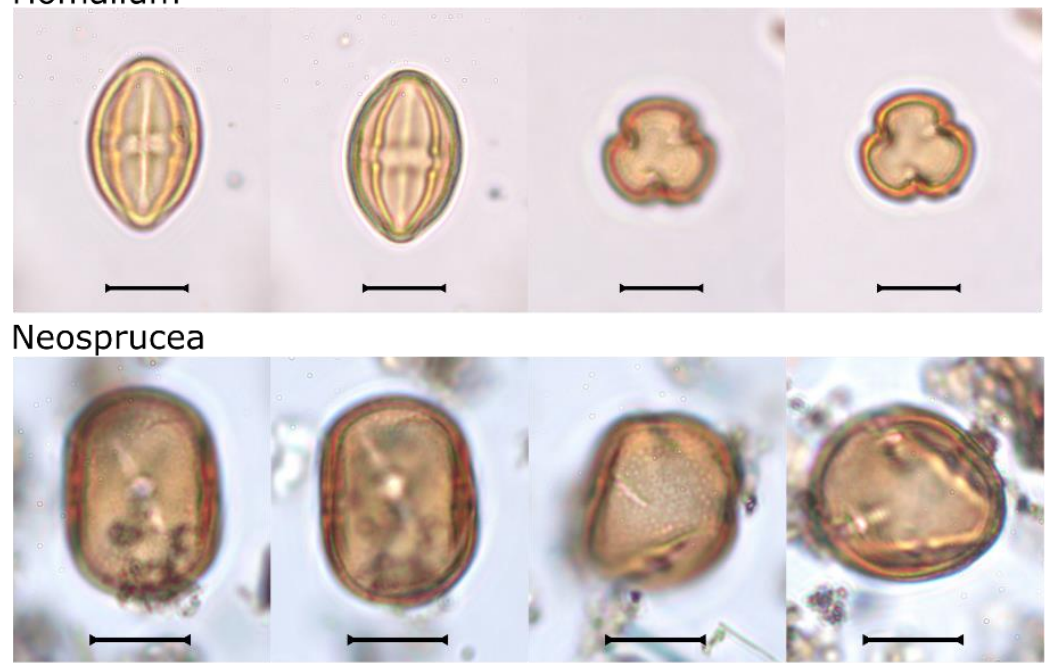

Salix

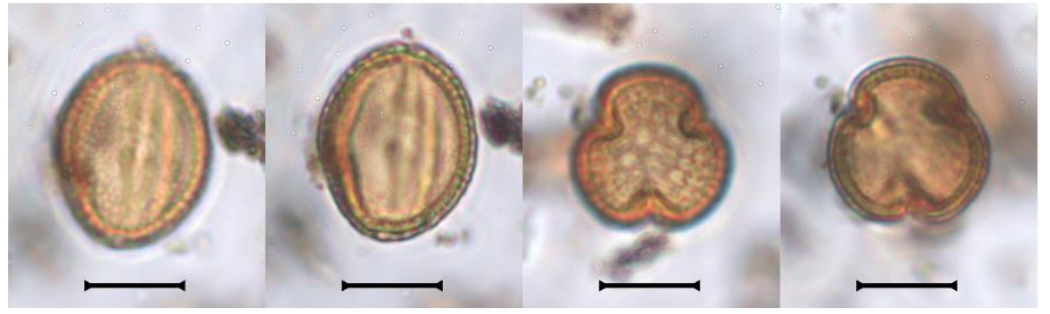

Xylosma

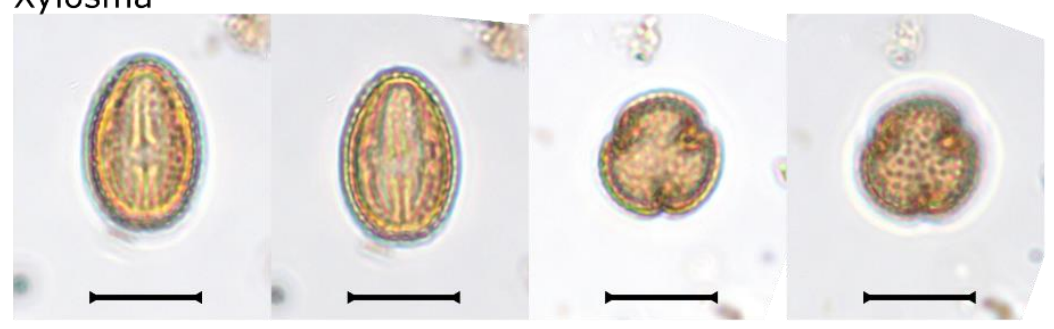

Salviniaceae

Azolla

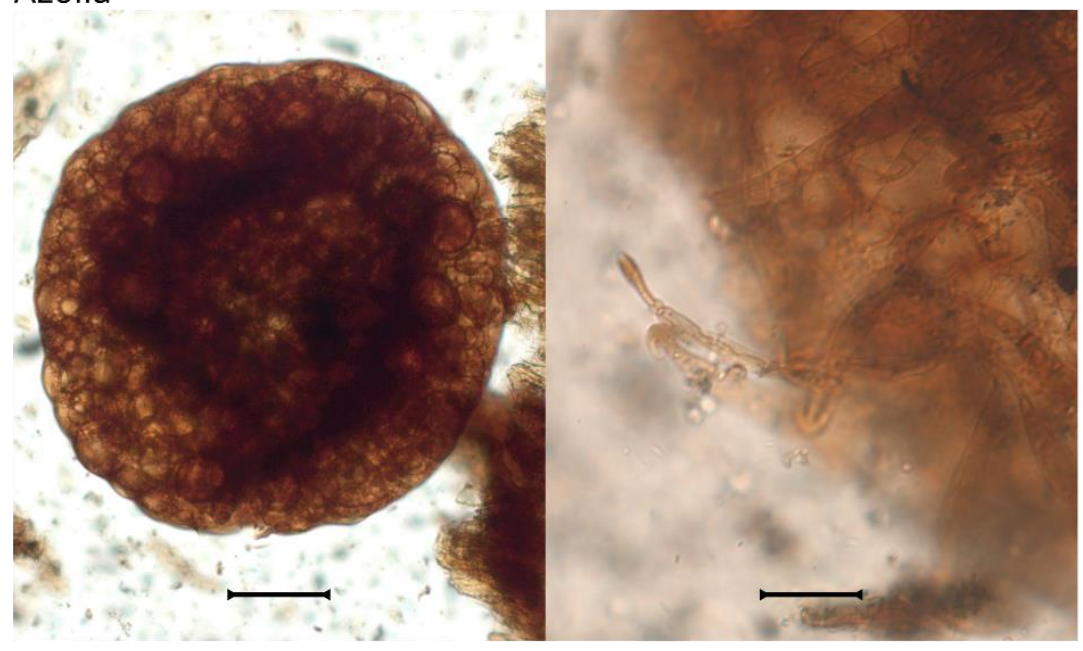


Sapindaceae

Plate XL

Cupania

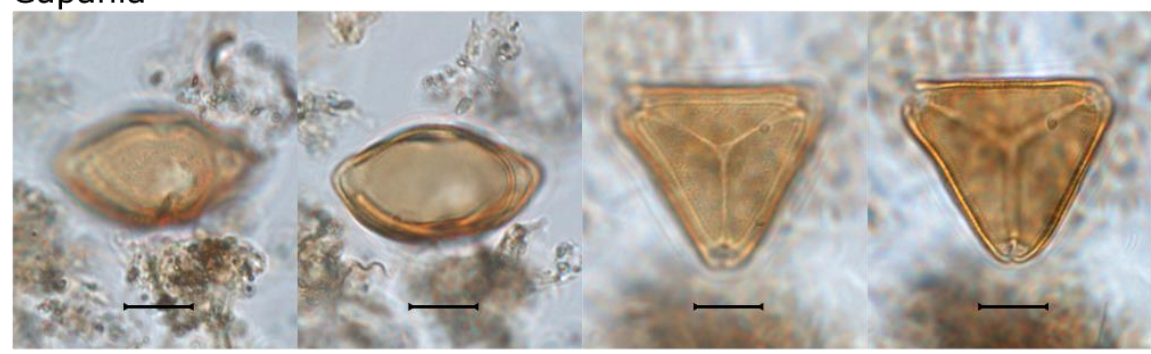

Paullinia

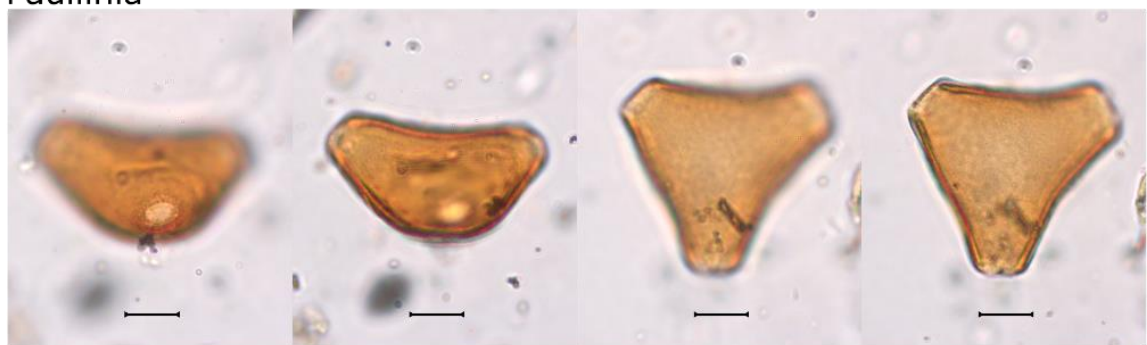

\section{Sapotaceae}

Diploon?

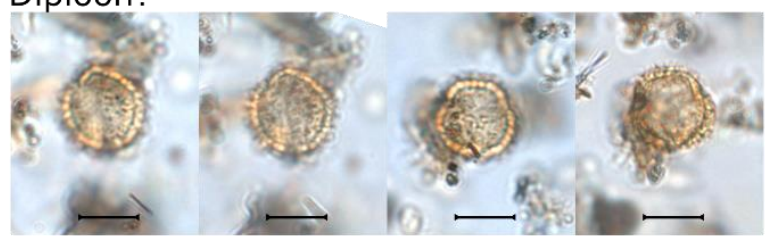

Manilkara

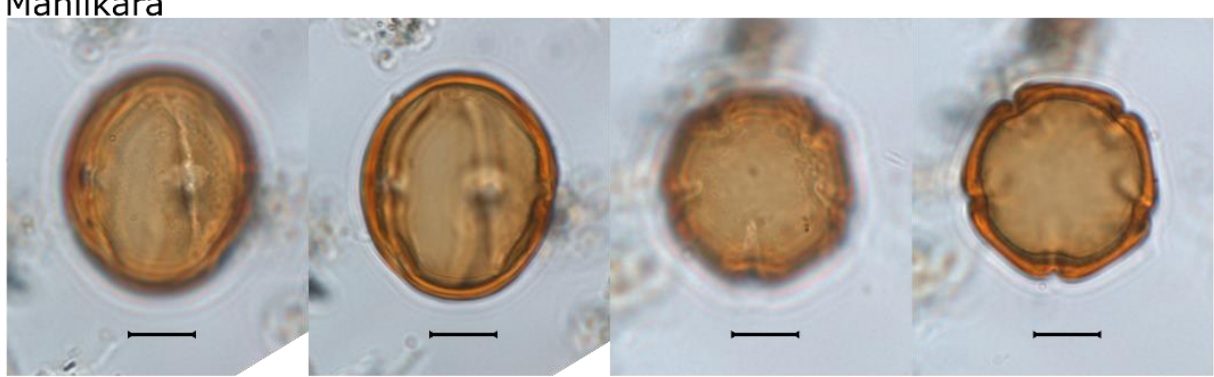

Micropholis

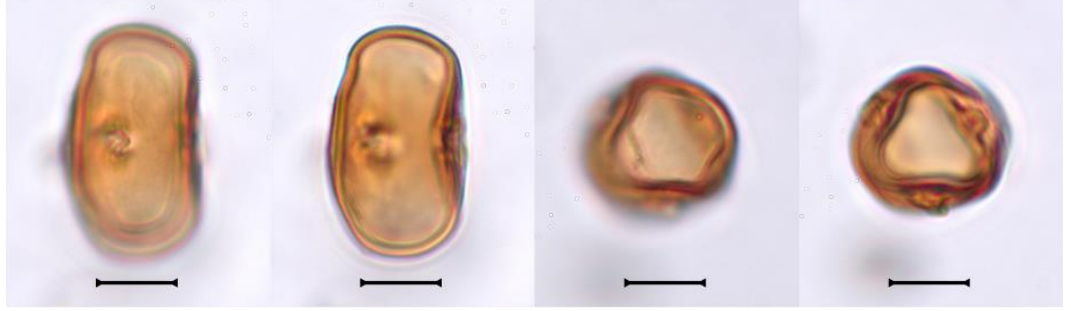

Pouteria

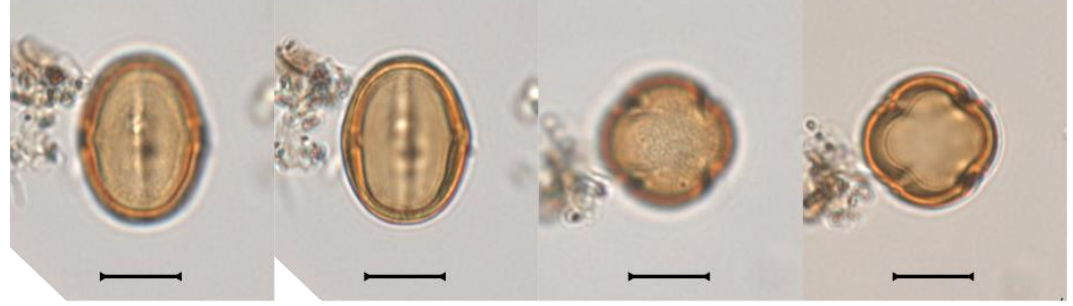


Solanaceae

Plate XLI

Capsicum
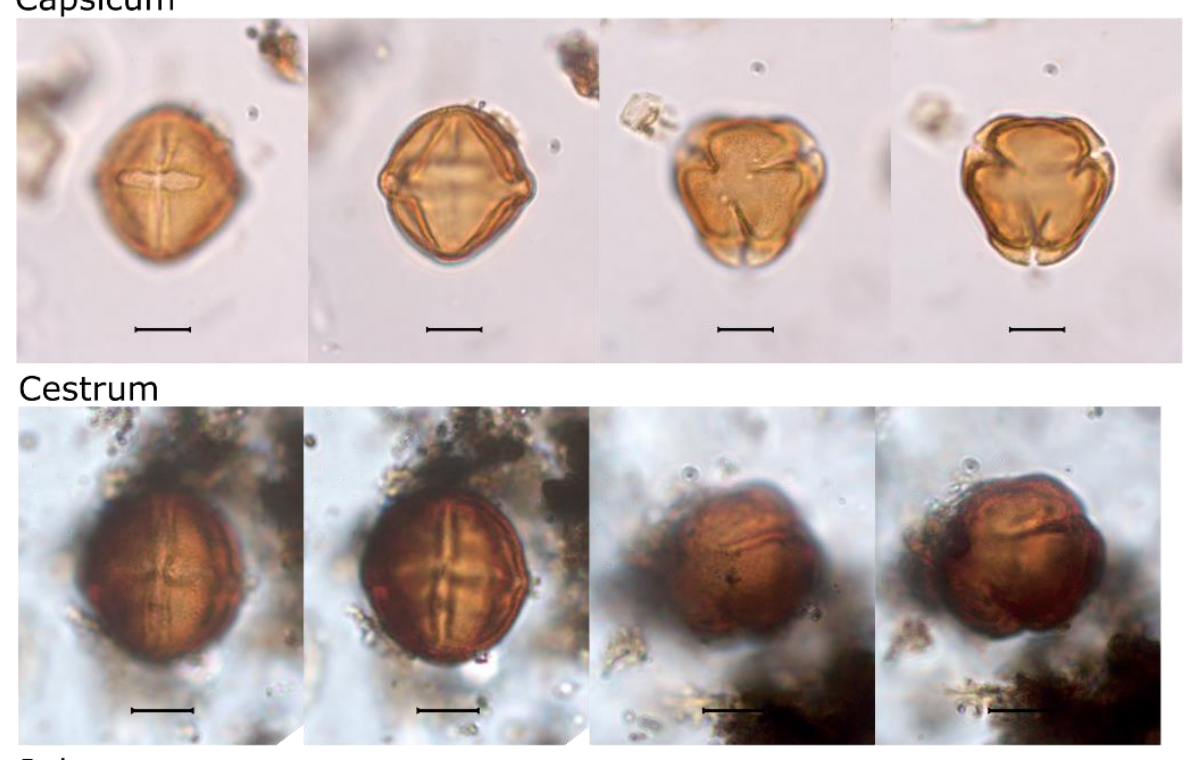

Solanum

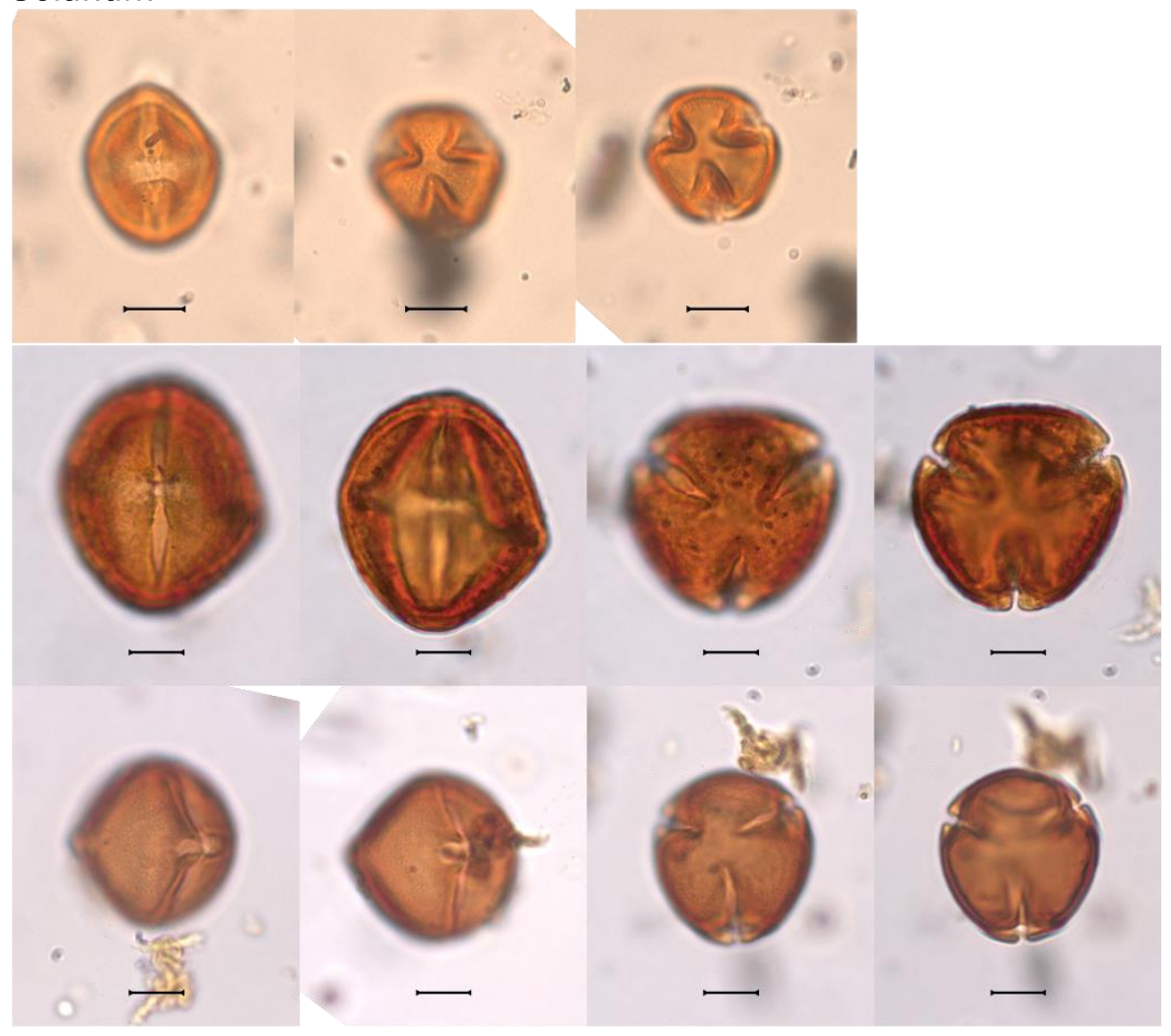

\section{Urticaceae}

\section{Cecropia}

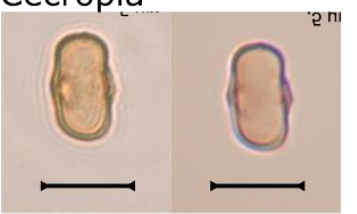


Verbenaceae

Plate XLII

Citharexylum

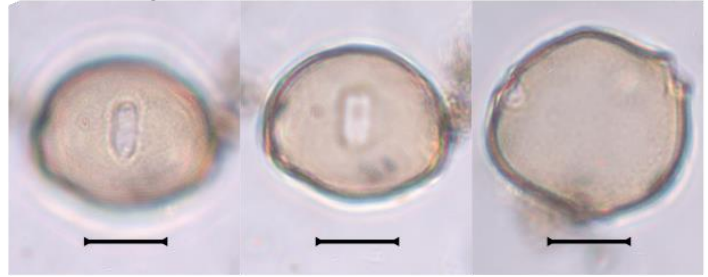

Phyla

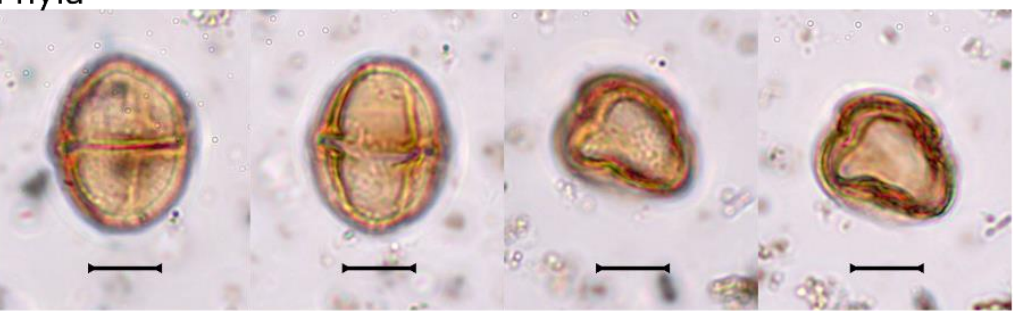

Vochysia

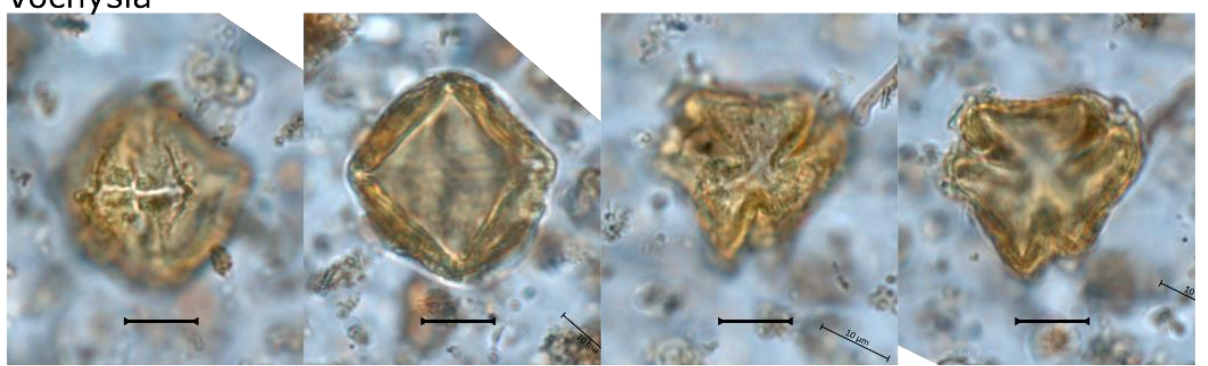

Reworked fossil grains

Acritarchs (Siluro-Devonian)

Ammonidium

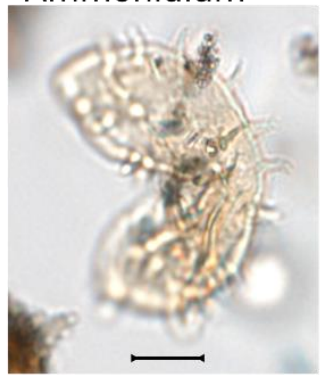

Veryhachium

Arecaceae (Neogene)

Grimsdalea

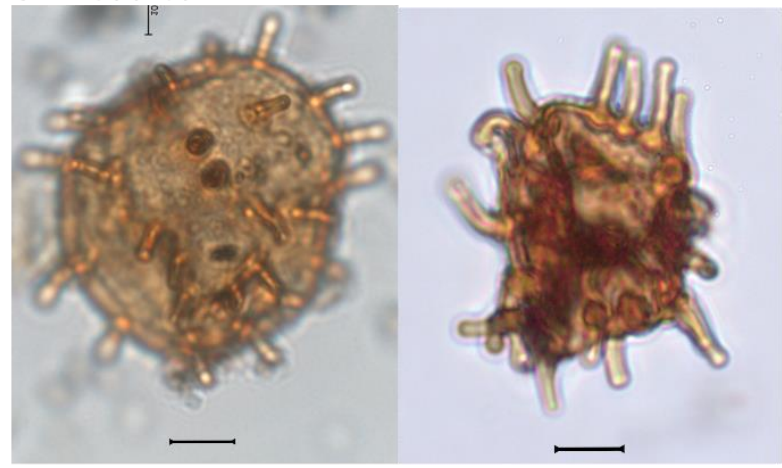

